\title{
SAMPLING AND ANALYSIS OF RADIOACTIVE LIQUID WASTES AND SLUDGES IN THE MELTON VALLEY AND EVAPORATOR FACILITY STORAGE TANKS AT ORNL
}

\author{
M. B. Sears \\ J. L. Botts* \\ R. N. Ceot \\ J. J. Ferrada \\ W. H. Griest* \\ J. M. Keller* \\ R. L. Schenley* \\ *Analytical Chemistry Division \\ tCurrently employed by the Y-12 Plant, Oak Ridge, Tennessec \\ Date Published - September 1990)

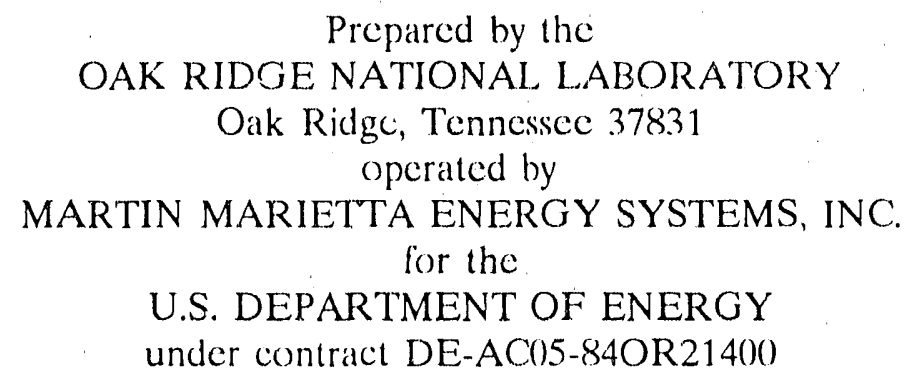 \\ under contract DE-AC(5-84OR21400)
}

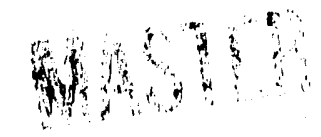




\section{TABLE OF CONTENTS}

LIST OF FIGURES $\ldots \ldots \ldots \ldots \ldots \ldots \ldots \ldots \ldots \ldots \ldots \ldots$

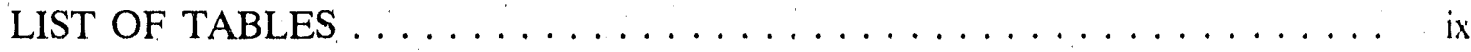

ACKNOWLEDGMENTS .....................

ACRONYMS AND INITIALISMS $\ldots \ldots \ldots \ldots \ldots \ldots \ldots \ldots \ldots \ldots$

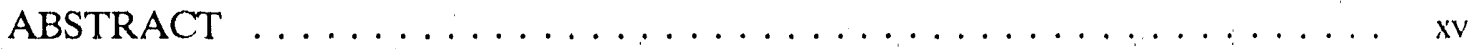

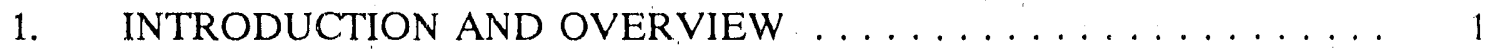

$1.1 \quad$ REFERENCE ...................... 4

2. BACKGROUND AND SAMPLING CONSIDERATIONS $\ldots \ldots \ldots \ldots$

2.1 LIQUID LOW-LEVEL WASTE SYSTEM $\ldots \ldots \ldots \ldots \ldots \ldots \ldots$

2.2 EARLIER SAMPLING CAMPAIGNS $\ldots \ldots \ldots \ldots \ldots$

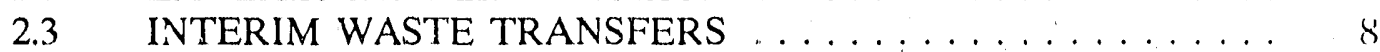

2.4 CONSIDERATIONS IN SAMPLING ........... \&

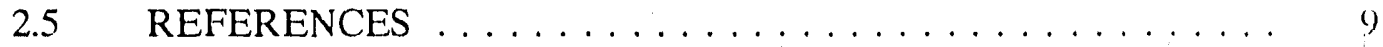

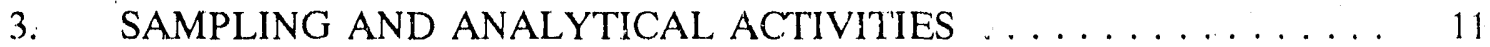

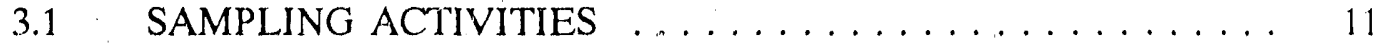

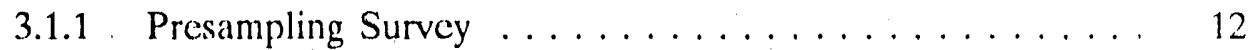

3.1.2 Collection of Liquid Samples with the Vacuum

Pump System ...................... 12

3.1.3 Air-Liquid Interface . . . . . . . . . . . . . . . 14

3.1.4 Collection of Sludge Sampies . . . . . . . . . . . 15

3.1.5 Sampling Tanks W-29 and W-30 with the Pump

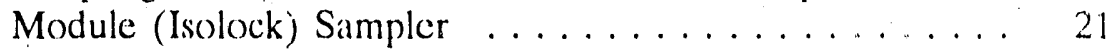

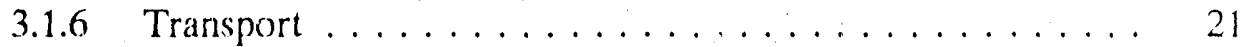

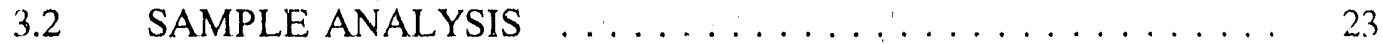

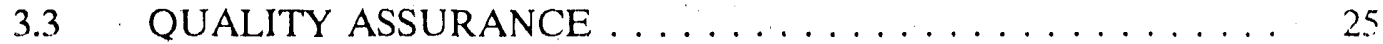

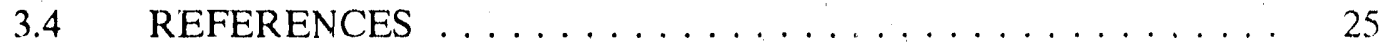

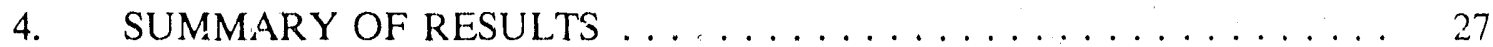

4.1 SAMPLE COLLECTION AND GENERAL CHARACTERISTICS 27

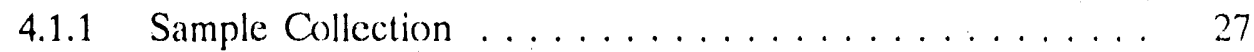

4.1.2 General Characteristics ................ 28

4.1.3 Checks for Water-Insoluble Organic Liquids . . . . . . . . 32

4.1.4 Inventory of Radioactive Liquid Wastes and Sludges . . . 32

4.2 INORGANIC, PHYSICAL, AND RADIOCHEMICAL

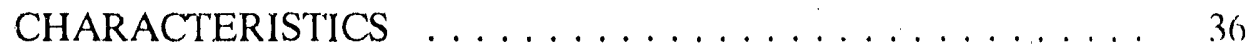

4.2.1 Analytical Results . . . . . . . . . . . . . . 36

4.2.2 Overall Trends and Solubility ............. 36 
4.2.3 Inorganic and Physical Characteristics of Liquid Samples 43

4.2.4 Inorganic and Physical Characteris ics of the Sludges .... . 47

4.2 .5 Radioactive Materials . . . . . . . . . . . . 48

4.2.6 RCRA Evaluation for Inorganic Species . . . . . . . . . 51

4.3 SUMMARY OF ORGANIC CHEMICAL CHARACTERIZATION' 55

4.4 DISCUSSION AND RECOMMENDATIONS . . . . . . . . 63

$4.5 \quad$ REFERENCES ........................ 65

APPENDIX A: $\quad$ FIELD SAMPLING DATA $\ldots \ldots \ldots \ldots \ldots \ldots \ldots$ A-1

APPENDIX B: INORGANIC AND RADIOCHEMICAL ANALYTICAL

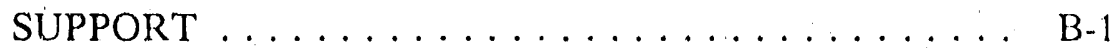

APPENDIX C: $\quad$ COMPREHENSIVE LISTING OF PHYSICAL,

INORGANIC, AND RADIOCHEMICAL ANALYTICAL

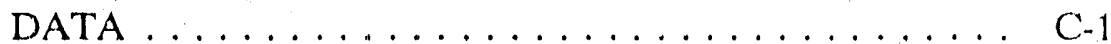

APPENDIX D: $\quad$ ORGANIC CHEMICAL CHARACTERIZATION $\ldots \ldots$ D- 1

APPENDIX E: SAMPLING PROCEDURES - MELTON VALLEY AND

EVAPORATOR STORAGE TANKS FOR WASTE

CHARACTERIZA'TION ............. E-1

APPENDIX F: $\quad$ PROCEDURE FOR SAMPLING TANKS W-29 AND

W-30 USING THE PUMP MODULE (ISOLOCK)

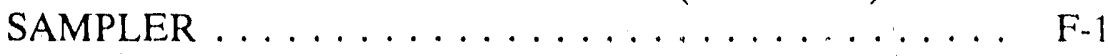




\section{LIST OF FIGURES}

Fig. 2.1.1 Schematic of the liquid low-level waste system $\ldots \ldots \ldots \ldots \ldots$

Fig. 2.4.1 Tank configuration with sampling locations $\ldots \ldots \ldots \ldots \ldots$ i()

Fig. 3.1.1 Liquid sample collection system $\ldots \ldots \ldots \ldots \ldots \ldots$

Fig. 3.1 .2 Soft-sludge sampler $\ldots \ldots \ldots \ldots \ldots \ldots \ldots \ldots \ldots$

Fig. 3.1.3 Schematic of sampling sludge layers $\ldots \ldots \ldots \ldots \ldots$

Fig. 3.1.4 Schematic of pump-module sampling system for tanks

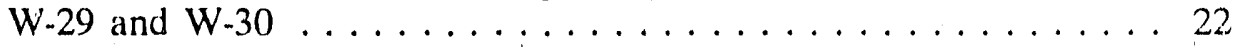

Fig. 3.2.1 Overall analysis scheme for contents oi ORNL liquid low-level waste storage tanks ...................... 24

Fig. 4.1.1 Profile of wastes in the Melton Valley Storage Tanks . . . . . . . 34 


\section{LIST OF TABLES}

Table 4.1 .1 General characteristics of waste samples . . . . . . . . . . . . . 29

Table 4.1 .2 Profiles of tank contents $\ldots \ldots \ldots \ldots \ldots \ldots \ldots$

Table 4.1.3 Inventory of radioactive liquid wastes and sludges in storage tanks ..................... 35

Table 4.2 .1 Analytical data for liquid samples . . . . . . . . . . 37

Table 4.2.2 Analytical data for liquid samples from tanks W-29 and W-30 . . 39

Table 4.2 .3 Uniformity of waste tank supernate $\ldots \ldots \ldots \ldots \ldots \ldots$. . . . .

Table 4.2 .4 Analytical data for sludge samples $\ldots \ldots \ldots \ldots \ldots \ldots$

Table 4.2.5 Major inorganic constituents of liquid samples . . . . . . . . . 44

Table 4.2.6 TRU-waste classification for sludge samples . . . . . . . . . . . . 49

Table 4.2.7 Estimates of nuclear materials in the sludges based on

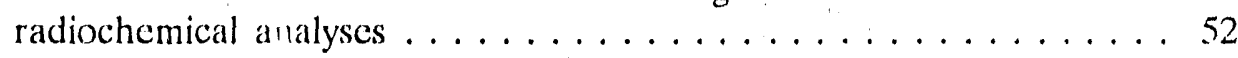

Table 4.2 .8 Regulatory lin ts for RCRA metals in solid waste . . . . . . . 53

Table 4.2.9 Preliminary screening for RCRA hazardous characteristics . . . . . . 54

Table 4.3.1 Target Compound List volatile organics and reporting limits . . . . 56

Table 4.3.2 Target Compound List semivolatile organics and reporting limits . . 57

Table 4.3.3 Results for volatile organic compound analysis of waste samples . . 60)

Table 4.3.4 Results from semivolatile organic compound analysis of

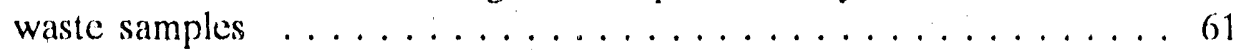




\section{ACKNOWLEDGMENTS}

The authors wish to express appreciation to the many staff members of the ORNL Analytical Chemistry Division who made important contributions to this work:

Inorganic and Radiochemical Analytical Support
C. J. Baggett
D. A. Caquelin
L. R. Hall
H. J. Hall
K. O. Jeter
R. A. Jones
B. K. Larkins
M. G. McClung
R. T. Pack
R. F. Peacher
J. M. Peele
C. W. Scott
J. E. Sutheriand
L. C. Tabor

\section{Organic Chemical Characterization}
G. S. Fleming
S. H. Harmon
L. J. Wachter
J. E. Caton
M. P. Maskarinec

The authors are also indebted to several stalf members of the Liquid and Gaseous Waste Operations Department of the Office of Waste Management and Remedial Actions for tank sampling services and field sampling data and to the Radiation Protection Department of the Office of Environmental and Health Protection. Special thanks go io the following individuals:

\section{Sampling Radioactive Waste Tanks}

J. D. Brewer

C. B. Scott

D. R. Anderson

D. T. Lewis

M. D. Nelson

K. Secber 


\section{ACRONYMS AND INITIALISMS}

\begin{tabular}{|c|c|}
\hline AA & Atomic Absorption \\
\hline $\mathrm{ACD}$ & Analytical Chemistry Division \\
\hline ALARA & As Low As Rcasonably Achicvable \\
\hline ASTM & America Socicty for Testing Materials \\
\hline $\mathrm{CB}$ & Calibration Blank \\
\hline CCS & Calibration Check Standard \\
\hline CLP & (EPA) Contract Laboratory Program \\
\hline CPA & Chemical and Physical Analysis (Group) \\
\hline DAIGC & Direct Aqueous Injection Gas Chromatography \\
\hline EASC & Emergency Avoidance Solidification Campaign \\
\hline EPA & Environmental Protection Agency \\
\hline EP-TOX & Extraction Procedure for Toxic Materials \\
\hline $\mathrm{GC}$ & Gas Chromatography \\
\hline GC/MS & Gas Chromatography/Mass Spectrometry \\
\hline GFAA & Graphite Furnace Atomic Absorption \\
\hline HEPA & High Efficiency Particulate Air \\
\hline $\mathrm{HP}$ & Health Physicist \\
\hline HRLAL & High Radiation Level Analytical Laboratory \\
\hline IC & Inorganic Carbon \\
\hline ICP & Inductively Coupled Plasma \\
\hline ICP-AES & Inductively Coupled Plasma Atomic Emission Spectroscopy \\
\hline ID & Internal Diameter \\
\hline IDL & Instrument Detection Limit \\
\hline IPA & Inorganic and Physical Analysis (Group) \\
\hline IR & Infrared Light \\
\hline LLLW & Liquid Low-Level Waste \\
\hline LLW & Low-Level Waste \\
\hline MVST & Melton Valley Storage Tank \\
\hline MSA & Method of Standard Addition \\
\hline OD & Outer Diameter \\
\hline ORNL & Oak Ridge National Laboratory \\
\hline PHA & Pulse-Hcight Analysis \\
\hline PRD & Percent Relative Difference \\
\hline PVC & Polyvinyl Chloride (polymer) \\
\hline PWTP & Process Waste Treatment Plant \\
\hline QA & Quality Assurance \\
\hline $\mathrm{CC}$ & Quality Control \\
\hline RCRA & Resource Conservation and Recovery Act \\
\hline RSD & Relative Standard Deviation \\
\hline SVOA & Semivolatile Organic Compound Analysis \\
\hline TAL & Transuranium Analylical Laboratory \\
\hline TC & Total Carbon \\
\hline TCL & Target Compound List \\
\hline
\end{tabular}


ACRONYMS AND INITIALISMS (continued)

TCLP

TDS

TIC

TOC

TRU

TS

VOA

WHPP

WIPP
Toxicity Characteristic Leaching Procedure

Total Dissolved Solids

Tentatively Identified Compound

Total Organic Carbon

Transuranic

Total Solids

Volatile Organics Arralysis

Waste Handling and Packaging Plant

Waste Isolation Pilot Plant 


\begin{abstract}
The sampling and analysis of the radioactive liquid wastes and sludges in the Melfon Valley Storage Tanks (MVSTs), as well as two of the evaporator service facility storage tanks at ORNL, are described. Aqueous samples of the supernatint liquid and composite samples of the sludges were analyzed for major constituents, radionuclides, total organic carbon, and metals listed as hazardous under the Resource Conservation and Recovery Acl (RCRA). Liquid samples from five tanks and sludge samples from three lanks were analyzed for organic compounds on the Environmental Protection Agency (EPA) Targel Compound List. Estimates were made of the inventory of liquid and sludge phatses in the tanks. Descriptions of the sampling and analytical activities and tabulations of the results are included.

The report provides data in support of (1) the design of the proposed Waste Handling and Packaging Plant, (2) the Liquid Low-Level Waste Solidilication Project, and (3) research and development activities (R\&D) activities in developing waste management alternatives.
\end{abstract}




\title{
SAMPLING AND ANALYSIS OF RADIOACTIVE LIQUID WASTES AND SLUDGES IN THE MELTON VALLEY AND EVAPORATOR FACILITY STORAGE TANKS AT ORNL.
}

\author{
M. B. Scars, J. L. Botts, R. N. Ceo, J. J. Ferrada, \\ W. H. Griest, J. M. Keller, R. L. Schenley
}

\section{INTRODUCTION AND OVERVIEW}

Purpose and sconc. The purpose of this study was to determine the characteristics of the radioactive liquid wastes and sludges stored at the Oak Ridge National Laboratory (ORNL). This project is a preliminary step in planning the processing of these wastes for disposal. Objectives include providing data in support of (1) the design of the proposed Waste Handling and Packaging Plant (WHPP), (2) the Liquid Low-Level Waste Solidification Project, and (3) research and duvelopment (R\&D) activities in developing waste management alternatives. This report presents the results of an effort to sample and analyze the contents of the liquid radioactive waste storage tanks. A related report on physical properties tests (e.g., viscosity, 'sedimentation rate) of four of these samples is in preparation. 1

Liquid low-level wastes (LLLWs) are generated by various R\&D activities at ORNL. These wastes are collected, made basic, and concentrated by processing in the low-level waste (LLW) evaporator. The resulting concentrates are stored in eight lanks at the Melton Valley Storage Tank (MVST) facility (Building 7830) and four tanks at the evaporator facility (Building 2531) in Bethel Valley.

Samples of the supernatant liquid and sludge were collected from six of the MVSTs (tanks W-24 through W-28 and W-31) and from two of the storage tanks at the evaporator service facility (W-21 and W-23). These samples were analyzed for major chemical constituents, radionuclides, total organic carbon, metals lisied as hazardous under the Resource Conservation and Recovery Act (RCRA), and general waste characteristics. A scoping survey was made for volatile and semivolatile organic constiluents. Because of limited access into the tanks and the relatively high radiation levels of the waste, only one location in each tank was sampled (i.e., under the acesss pipe). Full characterization of the wastes under RCRA will be conducted when the wastes are processed for disposal and more representative samples can be collected. 
The supernatant liquids in tanks W-29 and W-30 were sampled and analyzed in preparation for a campaign to remove the supernate from the tanks and immobilize it in a cement matrix. This project, the Liquid Low-Level Waste Solidification Project, is being planned to increase the vailable storage capacity for LLLW and improve operating flexibility. The process will be similar to the Emergency Avoidance Solidification Carnpaign (EASC) conducted in 1988. Tanks W-29 and W-30 were modified at the time of the EASC to serve as feed tanks to the solidification equipment in addition to their storage function. Liquid samples were analyzed for major chemical constituents, radionuclides, total organic carbon, RCRA metals, volatile and semivolatile organic components, and general waste characteristics. Because of the tank modifications, it is not possible to gain access to sample the sludge in these particular tanks.

The two remaining storage tanks (C-1 and C-2) were not sampled because the tank design did not include sample access ports.

Background information on the LLLW system is given in Sect. 2, and an overvic:w of the field sampling and analytical activities in Sect. 3. The results of the waste characterization studies are summarized in Sect. 4. Details of the work are presented in the appendixes, including field sampling data (Appendix A), Analytical Chemistry Division support (Appendixes B-D), and the sampling procedures (Appendixes $E$ and $F$ ).

General characteristics of the waste samples. The liquid samples appeared to be single phase and ranged from pale to deep yellow. Dose rates (field survey) on contact with the full $250-\mathrm{mL}$ sample jars ranged from 0.1 to $0.5 \mathrm{R} / \mathrm{h}$ except for the samples from tank W-26, which measured $1.2 \mathrm{R} / \mathrm{h}$.

The sludges are not homogeneous. Soft sludges after sonication varied in consistency from "similar to prepared mustard" to "like peanut butter with gritty particles." Tanks W-27 and W-31 contained layers of "hard" sludge in addition to soft sludge. Dose rates (field survey) for the wet sludge samples ranged from 1 to $2.8 \mathrm{R} / \mathrm{h}$ for a $25($ )-mL sample. Dose rates of up to $50 \mathrm{R}$ per hour per gram were observed for dried sludge subsamples.

Major components. The supernatant liquid wastes in the storage tanks, exeept tank W-21, are essentially high-pH (typically 11 to 13), sodium/potassium nitrate salt solutions. The nitrate concentration varies from 3 to $5 \underline{M}$, with the average being about $4 \underline{\mathrm{M}}$. The waste solutions are about $0.08 \mathrm{M}$ in chloride; five tank solutions contain dissolved 
carbonate. The concentrations of the heavy metals (c.g., U, Th, RCRA metals), as well as the iron and aluminum, are generally in the low-ppm range. Tank W-21 was found to be acidic when it was sampled for this study and contained higher levels of heavy metals than the basic wastes.

The principal metals found in the sludges were sodium, potassium, calcium, magnesium, uranium, and thorium.

Alpha emitters (TRU waste) and beta-gamma emitters. All of the composite sludge samples except the soft sludge in tank W-31 were identified as transuranic (TRU) wastes. If the tank W-31 sludge were dried, then the solid residue would also be classified as a TRU waste.

In general, little or no alpha activity was observed in the basic liquid phases in the tanks. The liquid samples were all non-TRU solutions; their salt residues, if dried, would also be non-TRU.

The most abundant beta-gamma emitters observed were ${ }^{137} \mathrm{Cs}$ and ${ }^{90} \mathrm{Sr}$ and their short-lived daughters ${ }^{137} \mathrm{Ba}$ and ${ }^{90} \mathrm{Y}$, respectively. Gamma-active europium isotopes were observed in the sludges but were not detected in the liquid phase of any tanks that were basic.

RCRA characteristics. This study included some preliminary screening tests for RCRA hazardous characteristics. The full RCRA characterization was not performed due to budget limitations. The liquid phases in eight tanks were corrosive and/or contained a toxic metal at a conentration high enough to classify the waste as RCRA hazardous. The classifications of the sludge samples are preliminary, based on the total metal contents obtained with a nitric acid leach, and are not the EP-toxicity or the Toxicity Characteristic Leaching Procedure (TCLP) results. All sludge samples exceeded the EP-toxicity equivalent limits for mercury and lead and are potentially RCRA hazardous. That is, the metals content would result in the classification of the sample as RCRA hazardous if the sludge dissolved completely in the acetate buffer used in the regulatory test. Several sludge samples were also potentially RCRA hazardous with respect to chromium and cadmium.

Selected samples from the waste tanks were analyzed for the Environmental Protection Agency (EPA) Target Compound List (TCL) volatile and semivolatile organic compounds. Very few TCL compounds were found in the waste samples. 


\subsection{REFERENCE}

1. R. N. Ceo and J. T. Shor, Physical Characterization of Radioactive Sludges in Selected Melton Valley and Evaporator Facility Storage Tanks, ORNL/TM-11653, in preparation. 


\section{BACKGROUND AND SAMPLING CONSIDERATIONS}

\subsection{LIQUID LOW-LEVEL WASTE SYSTEM}

The LLLW system receives wastes from a variety of source facilities, including reactors, radioactive fuel and target processing areas, radioisotope processing areas, decontamination operations, hot cells, and radiochemical laboratories. A simplified schematic of the LLLW system is shown in Fig. 2.1.1. The wastes are gathered in collection tanks and transferred to the LLW evaporator feed tank (W-22 and formerly W-21).* Many of the source facilities generate acidic wastes. The wastes are made basic with sodium hydroxide in the collection tanks or in the evaporator feed tank, which precipitates most of the TRU and heavy metals.

The wastes are concentrated by processing in the LLW evaporator. This is a batch operation with the volume of the waste reduced until a yredetermined specific gravity (currently about 1.25 ) is reached. The final temperature is approximately $135-140^{\circ} \mathrm{C}$. The evaporator bottoms are discharged into tank W-23 and from there are pumped to other storage tanks. Concentrations of dissolver esids in the wastes in the MVSTs are somewhat lower than in the evaporator discharge because of dilution by the water used to rinse the transfer line. The waste stream has a relatively high activity level and is processed/stored in shielded facilities. The evaporator overheads are condensed and treated by the Process Waste Treatment Plant (PWTP).

The Process Waste Treatment Plant (PWTP) also generates LLLW. Process wastewater is waste that is slightly or potentially contaminated (steam condensate from heating coils, process cooling water, leakage, and miscellaneous waste from building sinks, floor drains, etc.). It is treated by ion exchange, and the effluent is routed to the Nonradiological Wastewater Treatment Plant for further treatment and is released. The discharge point is permitted under the National Pollution Discharge Elimination System (NPDES). The PWTP ion exchange columns are regenerated with nitric acid. A portion

*Some (or all) of the Bethel Valley and Melton Valley collection tanks may be shut down under the pending Federal Facilities Agreement, with wastes handled by bottling and/or treatment at the source and an unloading station at the LLW evaporator complex. 


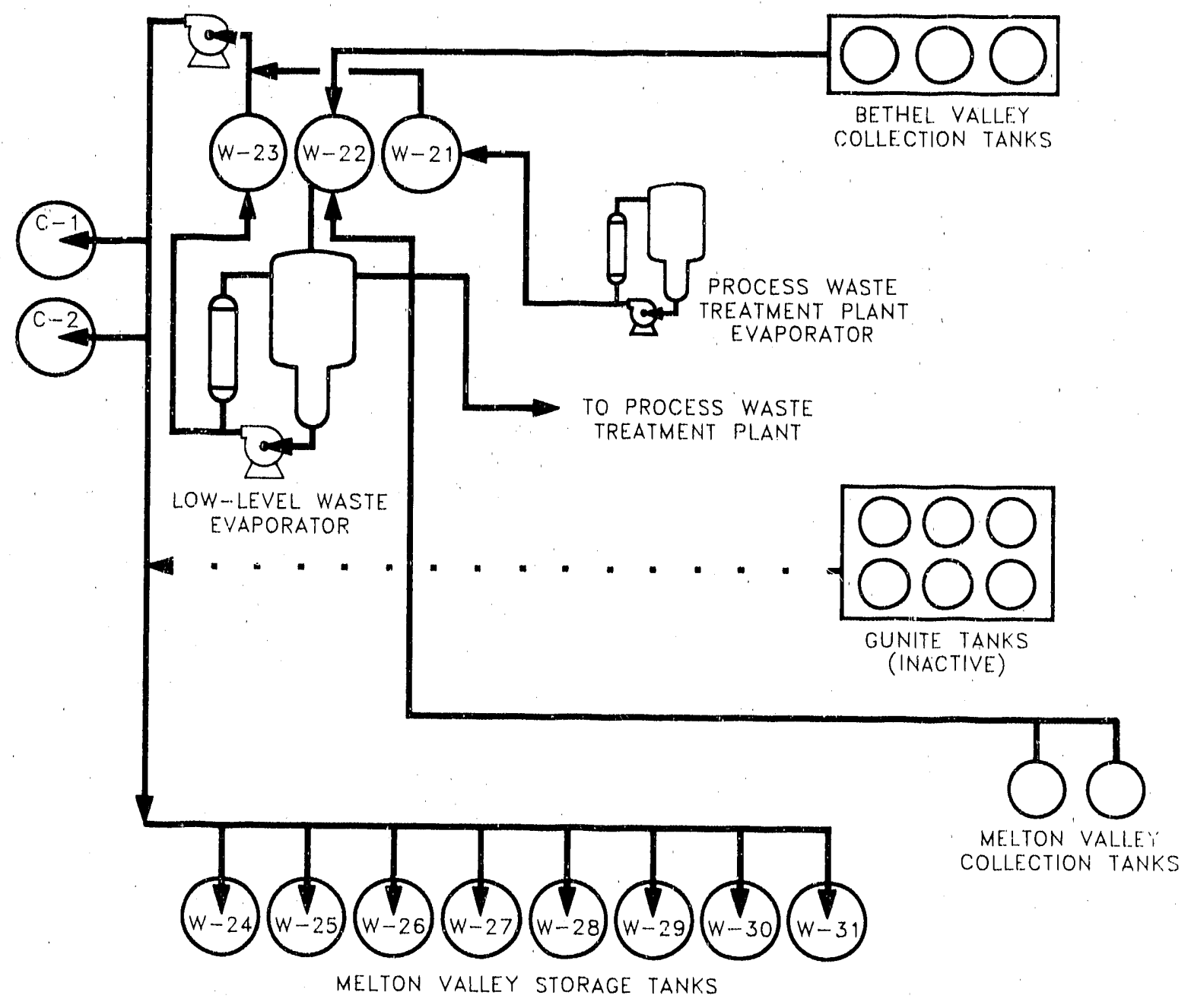

Fig. 2.1.1. Schematic of the liquid low-level waste system. 
of the resulting eluate is processed at the PWTP evaporator to recover nitric acid. The evaporator bottoms are transferred to the LLLW storage tanks. The remainder of the eluate is neutralized and routed to the LLW evaporator. Both PWTP concentrates and LLW concentrates are stored in tank W-21.

Through 1984, the waste concentrates were disposed of as a cement-waste mixture (grout) by injection into shale formations located 800 to $1100 \mathrm{ft}(250$ to $335 \mathrm{~m}$ ) below the ground surface using hydrofracture. The MVSTs sered both for interim storage and as feed tanks for the hydrofracture facility. Hydrofracture was terminated after 1984 and is not presently considered to be an acceptable disposal option.

The gunite tanks (now inactive) received LLLW during the period 1943-1978 and over the years accumulated a large quantity of sludge. Most of these sludges were resuspended, transferred from the gunite tanks to the MVSTs, and then disposed of by hydrofracture. However, some of the sludges settled out in the MVSTs.

The radioactive waste concentrates have been accumulated in tanks since the termination of hydrofracture, and the system is nearing capacity. These are primarily wastes generated since 1984 plus some heels from hydrofracture. Wastes are currently stored in eight 50,000-gal tanks (W-24 through W-31) in the MVST facility and four 50,000)-gal tanks (W-21, W-23, C-1, and C-2) at the LLW cvaporator service facility in Bethel Valley. To free some storage capacity, in 1988 about 48,000 gal of supernate were removed from tanks W-29 and W-30 and immobilized in a cement matrix in the EASC. The solidified waste (non-transuranic) has been stored on-site pending resolution of waste form performance criteria and disposal requirements.

Waste minimization efforts have reduced the quantity of LLLW generated. The more recently generated waste is more concentrated in radioactive materials (i.c. "hotter") than the older wastes.

Solidification campaigns or additional concentration of the liquid waste by evaporation will be used to maintain safe-fill conditions in the system until a permanent disposal method can be implemented. The longer-range plan is to remove the wastes from the tanks and process them in the proposed Waste Handling, and Packaging Plant (WHPP). It is expected that the solidified TRU waste will be shipped for disposal to the Waste Isolation Pilot Plant (WIPP) in New Mexico, which is under construction. 


\subsection{EARLIER SAMPLING CAMPAIGNS}

The MVSTs were sain, ied previously: (1) in 1985 by Peretz et. al, ${ }^{1}$ and (2) the supernates in tanks W-29 and W-30 in 1988 to plan the EASC. ${ }^{2}$.The 1985 data are primarily radiochemical, although there are some chemical composition data for the liquid phase. An extensive series of analyses was performed on the EASC samples. ${ }^{2}$ No sludge samples were taken at that time. Samples were collected from tank W-26 in March 1989 for a related study on physical properties of the sludge. 3

\subsection{INTERIM WASTE TRANSFERS}

Since these earlier sampling projects there have been waste transfers at the MVSTs including: 4,5

(1) Tank W-28 emptied (except a small heel) with contents transferred to the other MVSTs; W-28 refilled with waste from Bethel Valley tanks (July 1987),

(2) About 48,000 gal of waste removed from tanks W-29 and W-30 in the EASC (September-December 1988). Tanks refilled by transfers from W-25 and W-26 (May 1989),

(3) Tanks W-25 and W-26 refilled by transfers from Bethel Valley tanks in May and August 1989. Tank W-26 received principally waste from W-23.

At the time of the sampling for this study, the MVSTs were essentially filled to their working capacity, tank W-23 was the LLW evaporator catch tank, and W-21 was the PWTP evaporator catch tank. Tank W-21 also contained some LLW coneentrates and historical sludges from its service as an evaporator feed tank. The air spargers at the MVSTs had been turned "off" before the EASC campaign and left off until after sampling was compieted in December 1989, except brief periods when waste transfers were made. Following the August 1989 transfers, tanks W-25 and W-26 were air sparged for $24 \mathrm{~h}$ lo mix the liquid - the disturbed solids were then allowed to settle before sampling.

\subsection{CONSIDERATIONS IN SAMPLING}

The number, size, and type of samples collected was limited by the need to keep personnel radiation exposures to a minimum, and the limitations imposed by the tank configurations. 
The tanks contain large quantities of radioactive materlals that produce relatively high radiation fields. In the 1985 sampling of the MVSTs, the radiation levels of "core" sludge samples ranged from $200 \mathrm{mR} / \mathrm{h}$ at 6 in. to $4 \mathrm{R} / \mathrm{h}$ at 4 in. ${ }^{1}$ Any operation that brings the tank contents outside the shielded vaults will expose people to the radiation fields. The exposure could be to the workers actually sampling the tanks, the laboratory workers analyzing the samples, or people who work in surrounding areas.

The storage system is designed to handle radioactive wastes. The tanks are stainless steel, 12 -ft diam. by 60-ft long and are located in bolow-grade, reinforeed concrete vaults with stainless steel liners that provide radiation shiclding and secondary containment. Waste transfers are handled remotely. The tanks are equipped with air spargers and an off-gas sweep and are vented through a demister and HEPA fïter system to a stack. Access to the lank contents is very limited, generally consisting of one pipe, 3-in. diam. by about 9-lt long, that protrudes through the vault roof. A representative tank configuration is shown in Fig. 2.4.1. Samples can only be collected directly below the access port because the pipe is long and narrow. Tanks C-1 and C-2 are of a different design and do not have an access port; therefore, these tanks were not sampled in this campaign.

Tanks W-29 and W-30 at the MVST were modified to serve as the feed tanks to the EASC processing system. The tank penetrations were used for the pump module suction legs. Liquid samples can be pulled from the end of the suction leg using the pump module sampler. There is no access to tanks W-29 and W-30 for sampling the sludge.

\subsection{REFERENCES}

1. F. J. Peretz, B. R. Clark, C. B. Scott, and J. B. Berry, Characterization of LowLevel Liquid Wastes at the Oak Ridge National Laboratory, ORNL/TM-10218, December 1986.

2. R. M. Schultz, Oak Ridge National Laboratory, personal communication, June 30, 1988.

3. R. N. Ceo, A. J. Mattus, and J. T. Shor, Oak Ridge National Laboratory, personal communication, September $28,1989$.

4. J. J. Maddox, Oak Ridge National Laboratory, personal eommunication, October 26, 1989.

5. S. M. DePaoli, Oak Ridge National Laboratory, personal communication to M. B. Sears, March 20, 199). 
1
1
1
0
0
0
3
0
$\vdots$
0
0
0

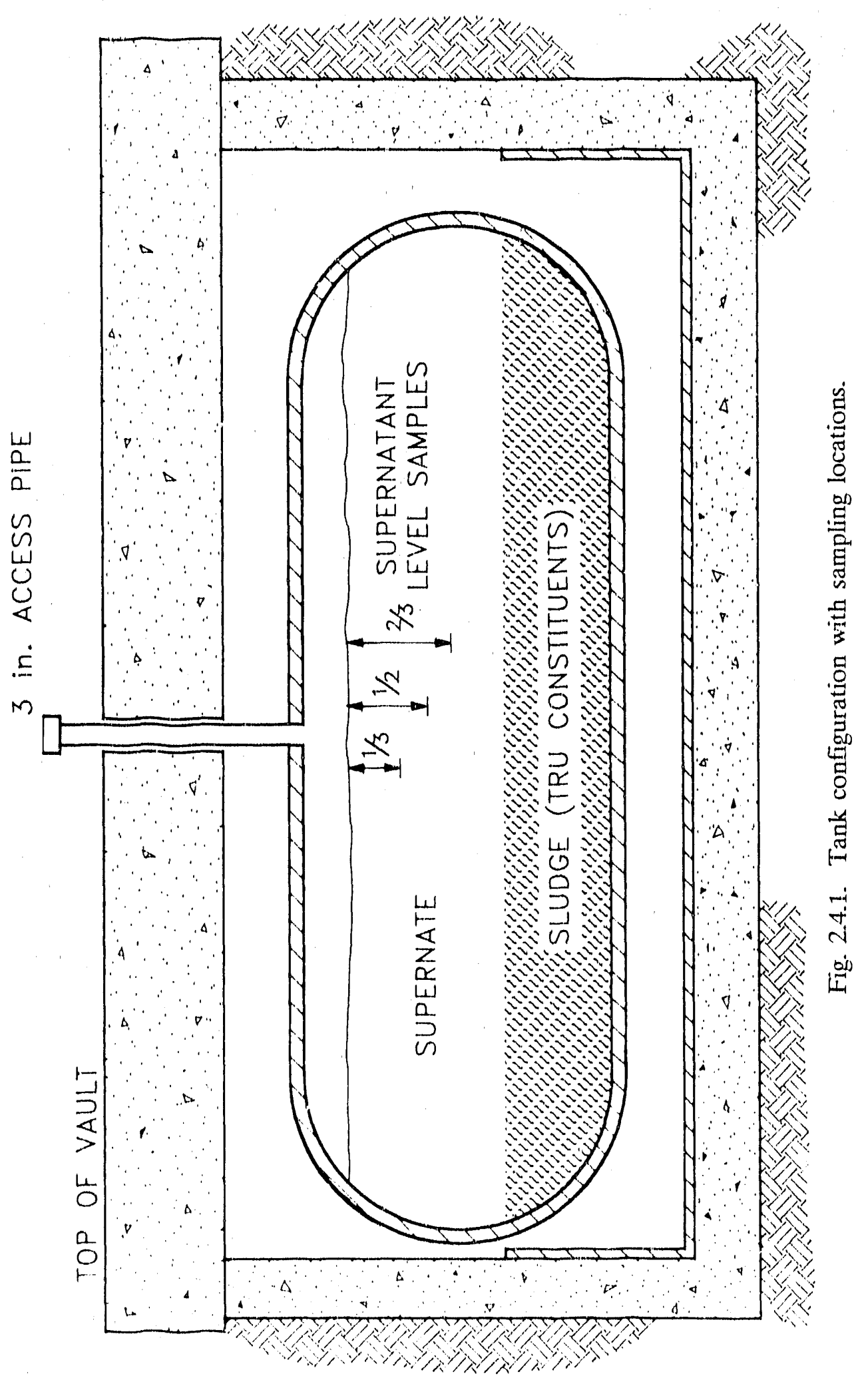




\section{SAMPLING AND ANALYTICAL ACTIVITIES}

\subsection{SAMPLING ACTIVITIES}

The sampling plan provides information eoncerning the supernatant liquid and sludges for six of the MVSTs (tanks W-24 through W-28 and tank W-31) and two of the concentrate storage tanks (W-21 and W-23) at the evaporator complex in Bethel Valley. Samples were drawn through the penctration used to house the liquid level instrumentation. The aceess is a 3-in.-diam. pipe that penetrates the tank from the vault roof. Liquid samples were taken at three levels - one-third, one-half, and two-thirds depth of the aqueous supernate (see Fig. 2.4.1). A sludge-level detector was used to determine the depth of the supernate and sludge. Samples representative of a vertical "core" of sludge were collected to pick up layoring in the waste. Because only sludge directly under the access port can be sampled, the samples may not be representative of other locations in the tank and should be considered merely an indicator of the tank contents. The air-liquid interface was checked for the presence of any immiscible (c.g., organic) layer.

Samples of the aqueous supernates in tanks W-29 and W-30 were collected using the pump module (Isolock) sampler. There is no aceess to sample the sludge in these tanks.

Sampling was conducted by trained chemical operators in protective elothing. Sampling activities were continuously monitored by the Health Physics (HP) representative.

A general description of the sample collection is presented in this section. Detailed, task-specific proeedures are given in Appendixes $E$ and $F$. These include general sampling procedures, instructions for the different types of samplers, presleaning and decontamination of equipment, sample custody, and field log records.

Samples were collected at the MVSTs during the period September 19 - December 5, 1989, and from tanks W-21 and W-23 at the evaporator service facility on January 3(). 31, 1990). There were no waste additions or transfers at the MVSTs during the period September 1, 1989 - January 31, 1990 while sampling was in progress. The air spargers for the MVST's had been ofl' sinec before the 1988 EASC, except when tanks W-25 and W-26 were sparged for about $24 \mathrm{~h}$ to mix the liguid contents alter the August 1989 waste transfiers. 


\subsubsection{Presampling Survcy}

A presampling survey was conducted before collecting the samples. At this time, the air-liquid and the liquid-sludge interfaces were located using the Markland Model 10 sli dge gun, thus establishing the depth of the supernatant liquid in the tank. This instrument measures the amount of light transmitled across a lixed gap in a probe. As the probe detects a phase change or enters the sludge, the operator logs the depth from the tank access point (i.e., the llange on the access pipe). This information was used in making linal plans for sample collection, and in estimating the volume of waste in the tank.

The presampling survey of the MVSTs was conducted about 2 weeks prior to collecting the samples. The liquid samples from tanks W-21 and W-23 were collected the same morning as the Markland measurements were taken.

The Markland instrument is capable of detecting immiscible liquid layers (e.g., an organic layer over the aqueous layer) if the layers are deep enough to give a reading with the probe, which is about 2 in. across vertically, No immiscible or stratified liquid laycrs were detected in the tanks with the Markland instrument.

\subsubsection{Collection of Liquid Samples with the Vacuum Pump System}

Samples of the supernatant liquid were collected from tanks W-21, W-23 to W-28, and W-31 using a vacuum pump sampling system. Samples were taken at one-third, one-half, and two-thirds the supernatant liquid level depth (sec Fig. 2.4.1), except tank W21 where the liquid layer was only 8 -in. deep (Markland) and only one level was sampled. A schematic of the sampling system is shown in Fig, 3.1.1. The sample was pulled by vacuum from the specilied level in the tank through Teflon tubing into the sample jar. The pump was arranged with a safety surge bottle as a back-up. The depth of the liquid phase and sampling locations were determined from the Markland measurements. Teflon lubing was cut to length, premeasured, and marked with tape to indicate when the end of the tubing had been lowered below the aceess pipe llange to the appropriate level in the lank liquid. A stainless steel weight was attached to the lower end to keep the tubing vertical. The upper end of the tubing was plugged while the tubing was lowered to restrict entry of licjuid until the desired depth was reached. After the sample was taken, the liquicl remaining in the tubing was drained back into the tank, and the tubing was removed. New tubing was used at cach sampling location to avoid cross contaminalion of the samples. 


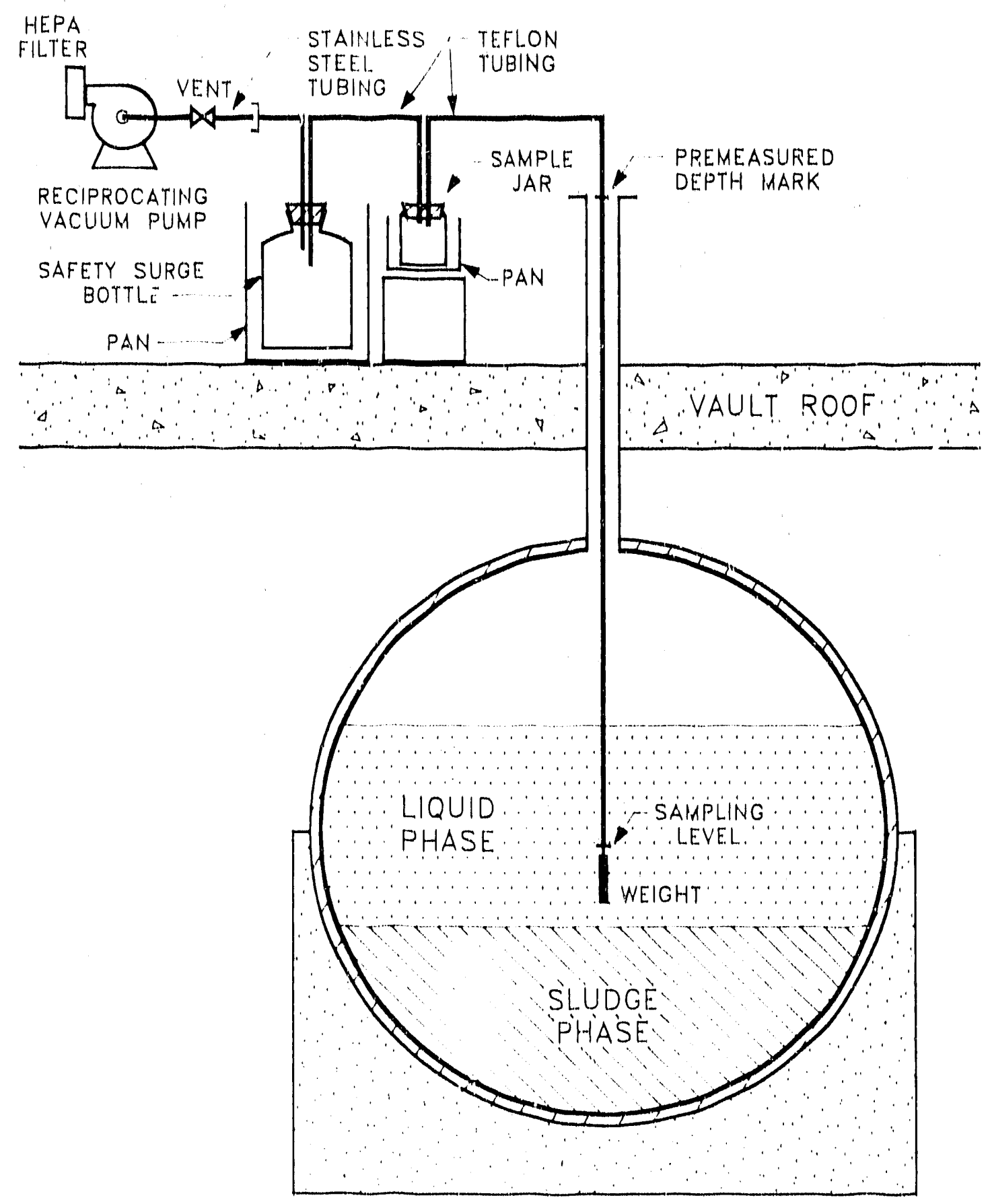

Fïg. 3.1.1. Liquid sample collection system. 
Liquid samples were collected in $250 \mathrm{~mL}$ glass sample Jars and sealed with Tellonlined caps. The radiation level of the unshiclded sample was measured by the HP. The sample was then placed in a lead pig, and the outer surface of the pig was montered by the HP. If the radiation level at the surface of the pig was $100 \mathrm{mrem} / \mathrm{h}$ or less, the sample was transported in the pig. Most of the liquid samples were below this level and were transported to the analytical laboratory in the pigs. The dose rates for the liquid samples from tank W-26 were higher than the others (about $280 \mathrm{mren} / \mathrm{h}$ at the outer surfiace ol' the pig). These samples were placed in a shielded stainless sted carrier for transport.

The use of a pump to collect the liquid samples rather than a dip-type sumpler or a Coliwasa minimized radiation exposure to personnel and was simple to operate. The liquid is purnped directly into the sample container, which reduces the handling time and the potential for drips or spills. The use of a vacuum pump to collect samples potentially might impact volatile organics; however, it secms unlikely that casily vaporized organics would be present in the waste following concentration in the evaporator.

\subsubsection{Air-Liquid Interface}

Wastes are segregated as much as possible, and in general the LLLW system is not used for the disposal of organic solvents. ${ }^{1,2}$ However, the waste aceeptance criteriil

are based on the primary hazard. ${ }^{2}$ Small quantitics of organics may be discharged to the LLLW system when the primary hazard of concern is the radioactivity. The air-liquid interface was checked for the possible presenec of an organic layer floating on the aqueous supernate. The bottom-opening soft sludge sampler (sec Sect. 3.1.4.1) was used to collect a "column" of liquid at the interface. The location of this interface was determined with the Markland detector during the presampling survey. Belore sampling, the appropriate length was measured on the handle of the sampling device, and the handle was marked with tape to show how deep to lower the sampler into the tank. The sample was pulled and examined visually in the field for the possible presence of immiscible licyud layers.

Samples from the air-liquid interface were drawn from the following lanks: W-2.l, W-2.3 through W-28, and W-31. The interlace was clear in all the samples with no immiscible phases. No organic layer was observed in any of these tanks. The inlerfice sample was returned to the tank and the sampler was then used to collect a sollt sluelge sample. 
While the bottom-opening sampler worked well as a method of checking the interface, it might not pick up a sufficient quantity of sample to do the chemical analyses. A top-opening sampler was developed for this project, which was designed to collect " larger sample of the organic phase if a relatively shallow organic layer were fourd. This deviec is described in Appendix E, Procedure SC-(0)7. As noted above, no layer was found and the organic sampler was never used. It was constructed of PVC and was designed to be capped and serve as the sample transport container to the analytical laboratory. A leach test $(48 \mathrm{~h})$ of the device was performed using hexanc as the solvent to eheck for organics that might leach from the PVC into an organic matrix sample (see Appendix D, Sects. D.2.5 and D.3.5). No detectable quantities of substances of concern were observed, which indicates that PVC is a satisfactory construction matcrial for short contact times.

\subsubsection{Collection of Sludge Samples}

Most sludge samples were collected with the soft-sludge sampler. If the consolidated sample could not be obtained with the soft-sludge sampler, "hard" sludge sampler with a sharper tip was used. Two tanks, W-27 and W-31, contained layers of "hard" sludge.

\subsubsection{Soft-Sludge Sampling}

A bottom-opening, soft-sludge sampler was used to collect a core of sludge up to 20-in. deep. The device consists of a detachable handle assembly and a hollow probe of clear PVC pipe with a bottom closure that can be controlled from above by the operator (Fig. 3.1.2). The design is a modification of the device developed for sampling the inactive tanks. ${ }^{3}$ The sludge was usually more than 20-in. deep in the tanks. Samples were collecited at suceessively lower layers to obtain a vertical profile.* Because the sample collector is a clear material, visual measurements ol sludge depth can be made and other properties observed. This examination was performed in a hot cell at the High Radiation Level Analytical Laboralory (HRLAL).

Sampling at different depths to provide "cores" representative of a vertical profile of the sludge is illustrated schematically in Fig, 3.1.3. The locations (depths) for collecting the sludge samples were developed from the Markland data on the location of the liquid-

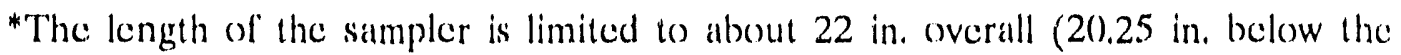
vent hole) by the remote handling capabilities at the analytical laboratory. 
ORNL DWG $90-148$

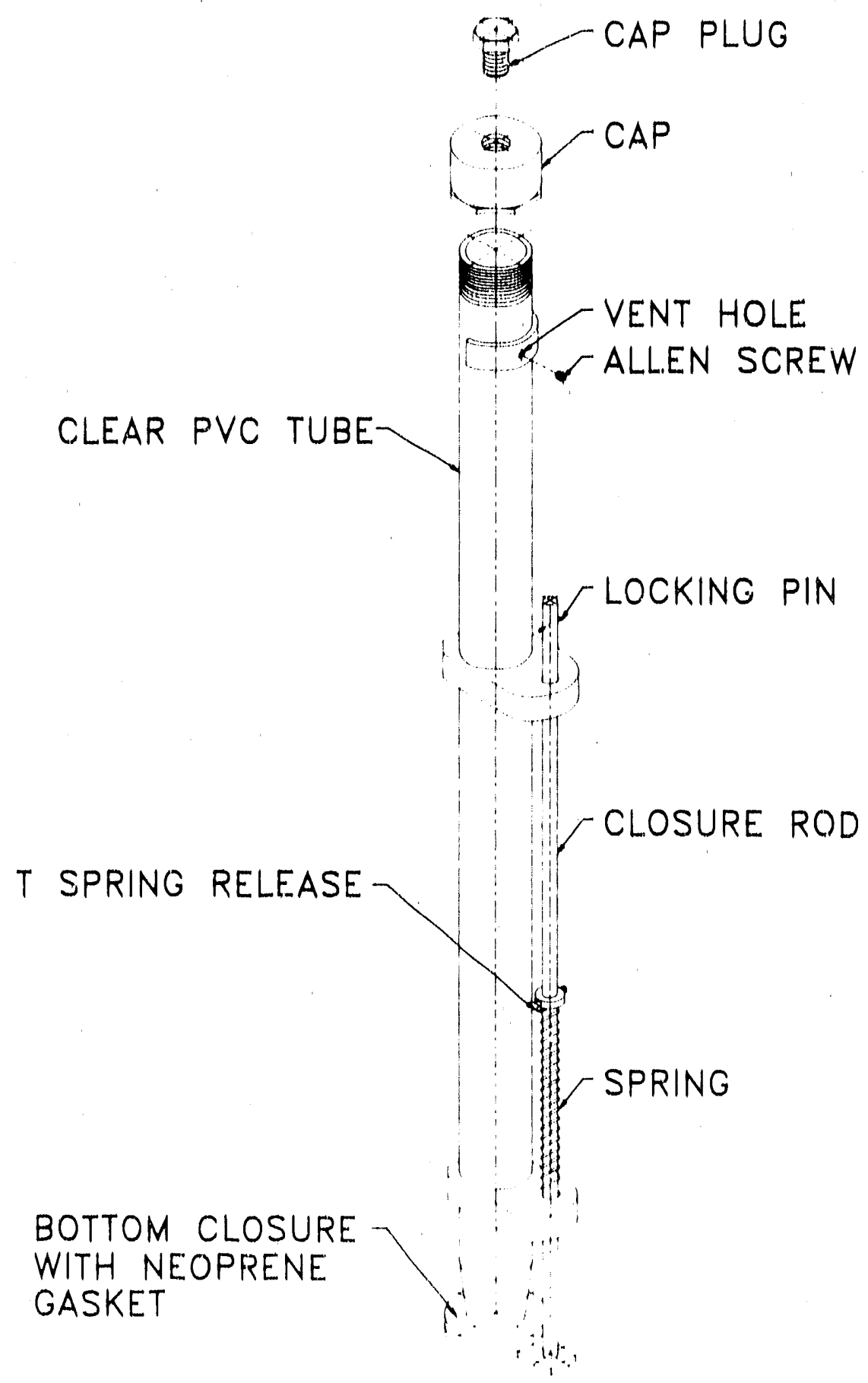

Fig. 3.1.2. Solt-sludge sampler. 

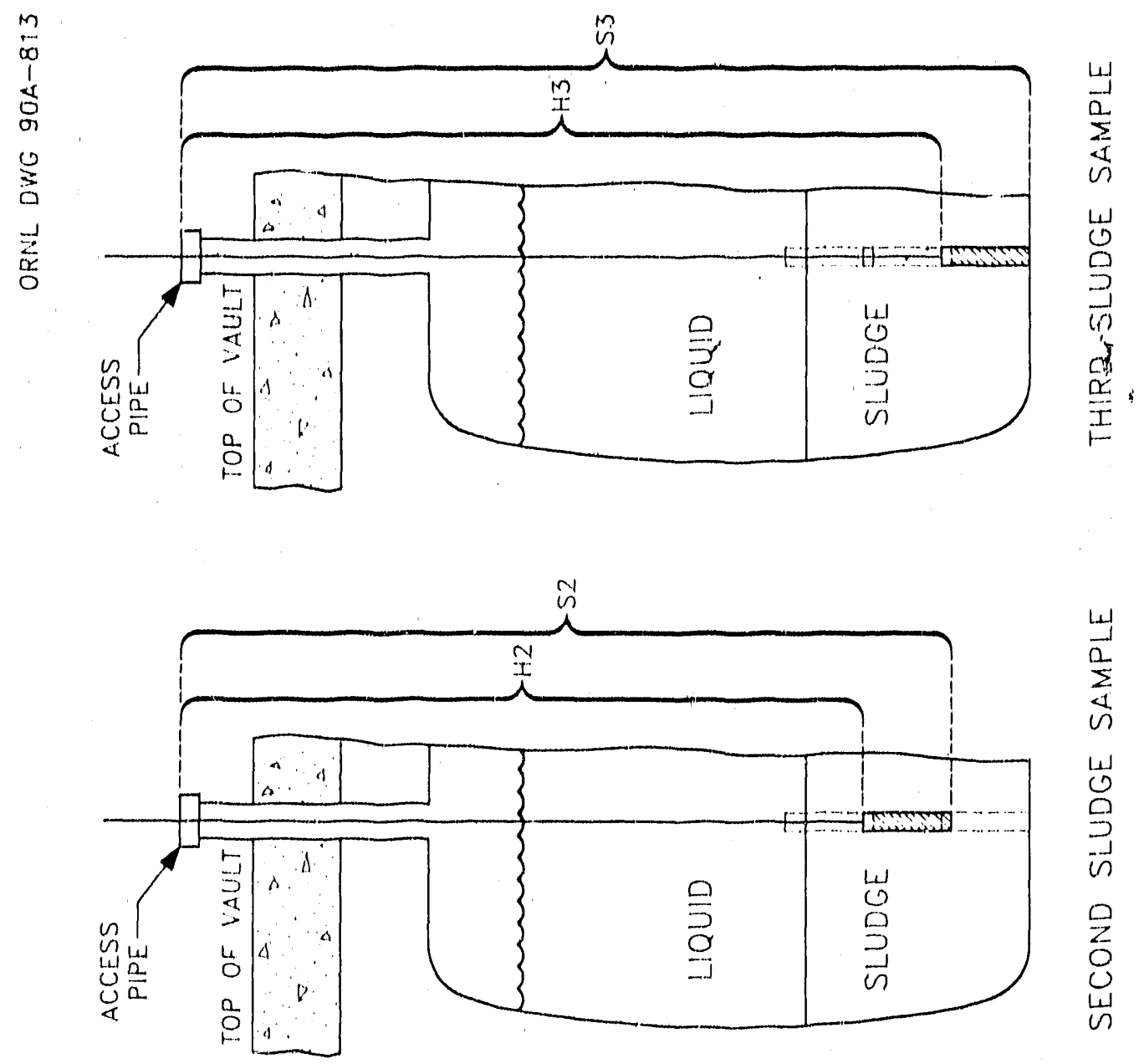

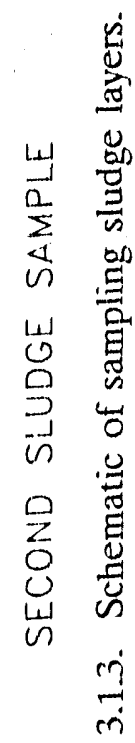

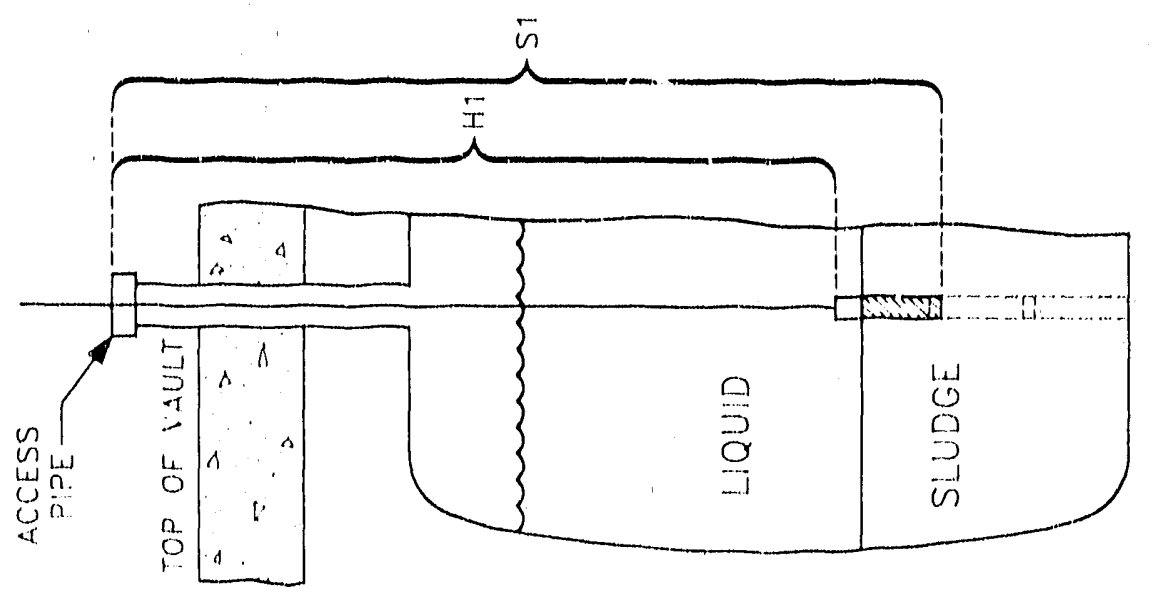

$\sum_{\substack{1 \\ n}}^{\frac{1}{2}}$

4
0
9
0
0

$n$
$\alpha$
$a$
1. 
sludge interface and the available information on the distance from the access point to the bottom of the tank. Specific depths were defined for collecting the upper samples. Before sampling the appropriate lengths were measured on the handle (e.g., H1, H2, ...) and marked with tape to show when the sampler had been lowered to the specified depth in the tank. The bottom sample was collected by pushing the sampler to the bottom of the tank. The depth to the tank bottom was recorded on the log sheet. In sampling lower layers, the sampler was closed until the bottom tip of the sampler was approximately 1 in. above the lowest point previously sampled. The sampler was then opened, lowered to the specified depth, and the sludge sample collected.

After a sludge sample was collected, the outside of the sampling device was rinsed with deionized water and wiped. The handle was removed, the PVC sample tube was capped, and the vent hole was plugged. The sampler was sealed in two layers of plastic bags and in a can, and the packaged sample was then placed in a shiclded, stainless steel transport carrier. The radiation level of the unshielded sample was measured by the HP in the field. This information was used by the analytical laboratory in planning sample handling.

In collecting the first batch of sludge samples, the samplers were rinsed while they were held in the access pipe to remove the sludge on the outside. There were some problems in sampling tank W-31 with the sludge dripping and spattering. To improve the confinement of radioactive materials, a large stainless steel funnel (2-ft. diam.) was custom fabricated before collecting the next batch of samples. This funnel was temporarily attached to the flange on the access pipe as each tank was sampled. The funnel served to contain drips or spills, facilitated rinsing the excess sludge from the outside of the sampler, and directed the rinse water back into the tank.

The samples were removed from the PVC sampling tubes and transferred to glass sample jars with Teflon-lined caps at the analytical laboratory using remote handling in a hot cell. A leach test (aqueous matrix) was performed to check for volatile or semivolatile organics that might leach from the PVC into the sample for the inartive tanks project. No detectable quantities of any substances of concern were observed.

The field sampling measurements of the depths to the tank bottoms from the access points are listed in Appendix A, Table A.1. For the MVSTs the depths generally were in the range $21 \mathrm{ft} 3$ in. to $21 \mathrm{ft} 6$ in., while for tanks W-21 and W-23 at the evaporator facility 
they were about $19 \mathrm{ft}$. The distances to the bottoms of the MVSTs were deeper than expected. There was an error in measuring the depth when tank W-26 at the MVST was sampled in March 1989 for a preliminary study of the physical properties of the sludge. 4 [The depths from the tank access points are not given on the drawings.] Because of this discrepancy in the tank dimensions, there is a gap in the cores from tanks W-24 and W-25. The missing segment is the layer that lies about 20 to 30 in. above the tank bottom. The sludge samp!ing plan was revised before sampling the other tanks.

An obstruction of unknown size and shape, which does not show on the drawings, was found in the access pipe to each of the MVSTs and to tanks W-21 and W-23 at the evaporator service facility, so that the access opening is less than the nominal 3 -in. diam. pipe. Because of the obstruction, it was necessary to make modifications to the sampling equipment after the sampling activities had begun. It was also necessary to "snake" the equipment past the obstruction. The original plan had been to use the handle comprised of 5-ft sections that was used in the inactive tank sampling project. This handle was tried in tanks W-23, W-24, and W-25, but would not clear the obstruction. A handle comprised of two 12-it sections, which was more rigid, but less convenient, was used successfully. ${ }^{*}$ It is thought that the obstruction is at the flange, where the access pipe is connected to the tank.

\subsubsection{Hard-Sludge Sampling}

Commercial Hard Sludge Sampler. The earlier work by Peretz et al. ${ }^{5}$ had indicated the presence of a hard crusty layer in tank W-27 that might require cutting blades to take a sample. A commercial hard-sludge sampler with an auger type bit was used for this layer. This sampler consists of a stainless steel pipe (barrel) about 1.4- ID by 10 -in. long, sharpened blades at the bottom, a gate valve to hold the sample in place, a vented cap, and handle sections. A schematic of a sampler similar to the one used is shown in Appendix E, Procedure SC-(0)4. (The stainless steel sampler was used without the plastic liner shown on the figure.) A cross handle was used to apply a turning pressure to cut the

\footnotetext{
*There is only one handle comprised of two 12-ft sections. For future tank sampling, it is recommended that a spare handle(s), especially the bottom section, which gets contaminated with sludge, be procured.
} 
sludge. After the sample had been taken, the sampler was rinsed with deionized water, wiped (except the blades), detached from the handle, and placed in a PVC container with a quick release, O-ring seal cap. The PVC container was put into a can and then into the transport carrie ${ }_{2}$ The auger bit cut through the hard layers, but the hard sludge plugged the sampler and a sample of the underlying soft layers was not obtained (see Sect. 3.1.4.3).

Alternate Hard-Sludge Sampler. The hard-sludge sampler developed for the inactive tanks sampling project ${ }^{3}$ was used to sample the thick material near the bottom of tank W-31. This device consists of a stainless steel pipe (7.25 in. long) that has a sharp, machine-bevel cutting edge on one end and is threaded at the other end so that it can be attached to a handle. This sampler is suitable only for very thick, sticky sludges. The cores are stored in a specially designed stainless steel sample container.

On the first attempt to sample the sludge, the sampler was empty when it was pulled from the tanks. On the second try, the sampler was pushed into the bottom layer three times to force the sample in. After the sample had been collected, the sampling device was very quickly transferred to the sample container. The sample container was sealed in a paint can and placed in the transport carrier.

\subsubsection{Sampling sludges in tank W-27}

In the first samı. ng effort of tank W-27, a soft-sludge sample was collected at the supernate-sludge interface (sample W27-S1). When the effort vas made to sample the next layer of sludge, a very hard layer that felt like concrete was encountered about 38 in. above the tank bottom. This layer was hard enough to bend the stainless steel closure plate on the sampler and, thus, no sample was collected. A sample of the upper solt sludge layer (W27-S2) was collected later in the second sampling effort. This core overlaps the solids phase of sample W27-S1.

The auger bit sampler was used to cut through the hard layer. It was estimated that the hard layer was about 1-ft thick. The sampler was then pushed through an underlying soft sludge layer (no cutting force needed) to the bottom of the tank. Upon examination of the sampler (W27-H1) at the analytical laboratory, it was found that the hard sludge had plugged the lower part of the sampler (i.e. the cutting bit end between the blades and immediately above the gate valve). The "barrel" section of the sampler contained soft sludge from the upper layer. At the analytical laboratory, the soft sludge was poured into 
one jar (W27-H1-S) and the hard sludge was scraped with a spatula into a second jar (W27-H1-H). A sample of the soft sludge that lies under the hard sludge was not obtained.

\subsubsection{Sampling Tanks W-29 and W-30 with the Pump Modulc (Isolock) Sampler}

Tanks W-29 and W-30 were modified to serve as feed tanks to the EASC system. The tank penetrations were used for the pump module suction legs. Samples of the aqueous supernate were collected from these tanks using the pump module (Isolock) sampler (Fig. 3.1.4). It is not possible to gain access through the penctrations to sample the tanks by the methods described in Sects. 3.1.1-3.1.4. No sludge samples were taken from tanks W-29 and W-30) and no checks were made for an organic layer.

A general description of the sample collection is presented in this section. The detailed procedure for using the pump module sampler is given in Appendix F. The transfer pump was used to pull liquid waste through the suction leg from one tank and circulate it through the sampler valve. The liquid loop discharges to the other tank. When the sampler is activated, the sampler valve cycles between the circulating liquid loop and the nozzle that drains to the sample collection jar. The collection jar, a standard "Mason" jar, screws into a fixed stainless steel cap on the sampler. This jar is too large to place in a lead pig, and the lid of the jar does not meet EPA specifications. The sample wats transferred to an I-Chem sample jar and capped with a Teflon-lined lid immediately after it was collected. After the samples were pulled from the first tank, the module piping was flushed with water. Liquid waste from the second tank was then circulated for a period before sampling the second tank.

Four samples were collected from each tank. The first, second, and fourth samples were transported to the laboratory for analysis. These are in essence triplicate samples since only one point in each tank, i.e., the end of the pump module suction leg, can be sampled. The third sample was placed in the archive storage area.

The equipment had not been operated since the EASC. Some maintenance was required to make the system operational. This included disassembly and cleaning of the solenoid for the air operated control valves for the sampler. The sampler operated slower than designed, probably because of corrosion.

\subsubsection{Transport}

The samples collected from the tanks were transported to the High Radiation Level Analytical Laboratory (Building 2026) in shielded containers. The routes connecting the 


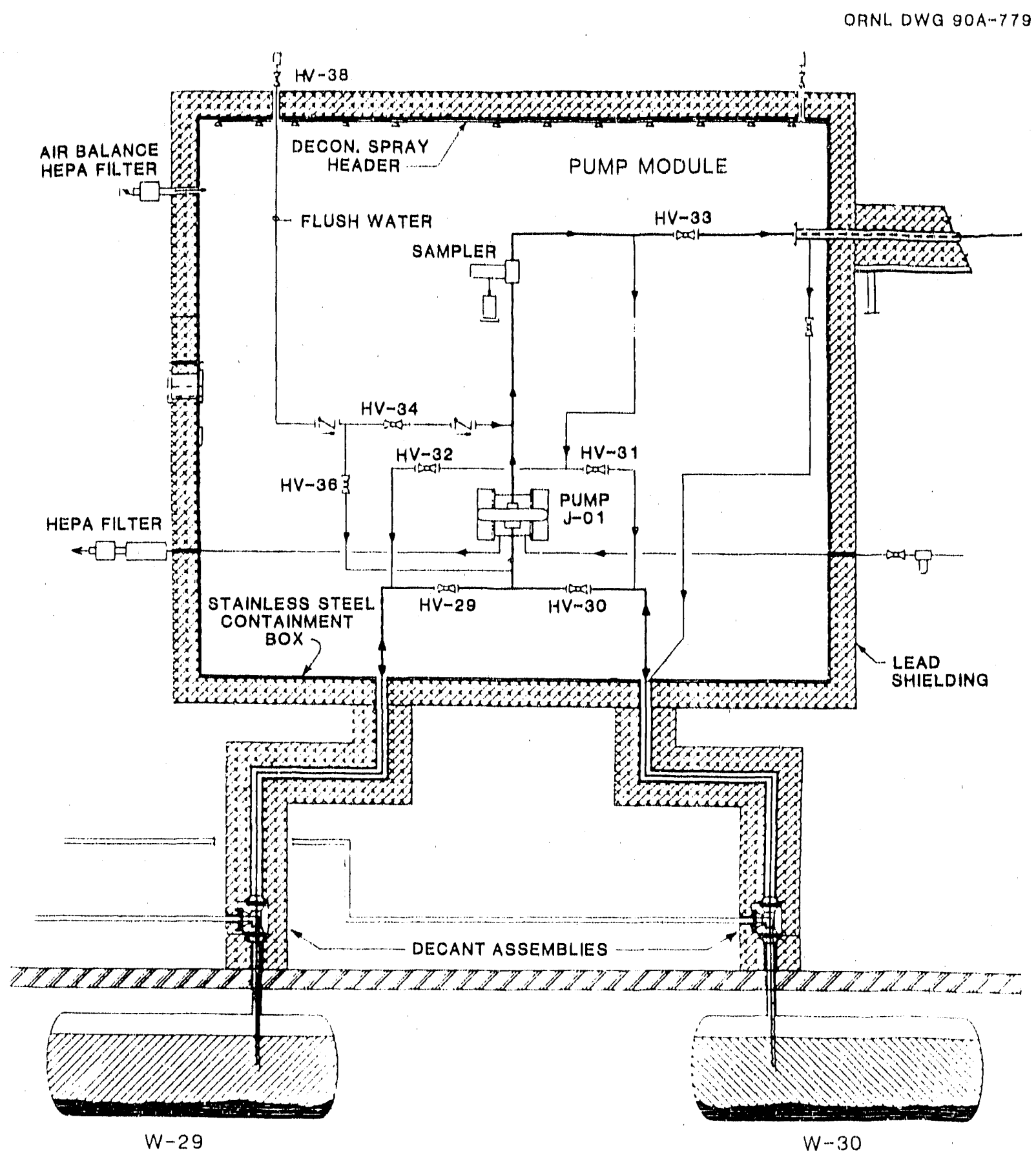

Fig. 3.1.4. Schematic of pump-module sampling system for tanks W-29 and W-30). 
lank areas and the analytical laboratory are within the controlled access areas of ORNL. Transport was carried out according to Health Physics Manual, Procedures 4.1, "Handling and Transfer of Radioactive Materials Within the Laboratory," and 5.1, "Segregation and Management of Solid Radioactive Waste Materials," which are standard ORNL practices

for the transport of contaminated materials. ${ }^{2}$ These procedures call for decontaminating and/or shielding the sample containers, as necessary, to maintain radiation levels at 20() $\mathrm{mrem} / \mathrm{h}$ or less at the outer surfaces of the transport packages.

Liquid samples, except those from tank W-26, were transported in lead pigs. Sludge samples and the liquid samples from W-26 were transported in a shielded, stainless stecl carrier. Samples were delivered to the analytical laboratory the day they were collected, except the liquid samples from W-26 which were too hot to handle in lead pigs. These samples were held overnight in a locked building and delivered the next day in the carrier along with a batch of sludge samples.

\subsection{SAMPLE ANALYSIS}

The purpose of the sampling was to obtain data that are meaningful and uscful in support of the program for the solidification and disposal of the liquid low-level wastes and sludges. The wastes were analyzed to determine (1) the major chemical constituents, (2) the principal radionuclides, (3) the total organic carbon, (4) any metals listed as hazardous under RCRA, and (5) some physical properties. A scoping survey was made of volatile and semivolatile organic compounds which are on the EPA Target Compound List (TCL).

The overall scheme used for the characterization of the waste tank contents is shown in Fig. 3.2.1. Liquid samples were examined visually. No immiscible layers (i.c., no organic layers) were observed. The aqueous sample drawn from the one-hall level of the supernale was analyzed for metals, anions, radionuclides, and total organic carbon. The aqueous samples from the one-third and two-thirds levels were screened to check the uniformity of the supernale.

The sludge column in the sampling tube(s) was inspected visually. The sludge was allowed to settle and the height of solids was measured. Any excess liquid was removed and the solids were transferred to a sample jar. Composite sludge samples were made up for each tank in proportions representative of a complete vertical core. Composite samples were sonicaled to ensure complete mixing. The remaining portion of the sludge was 
员

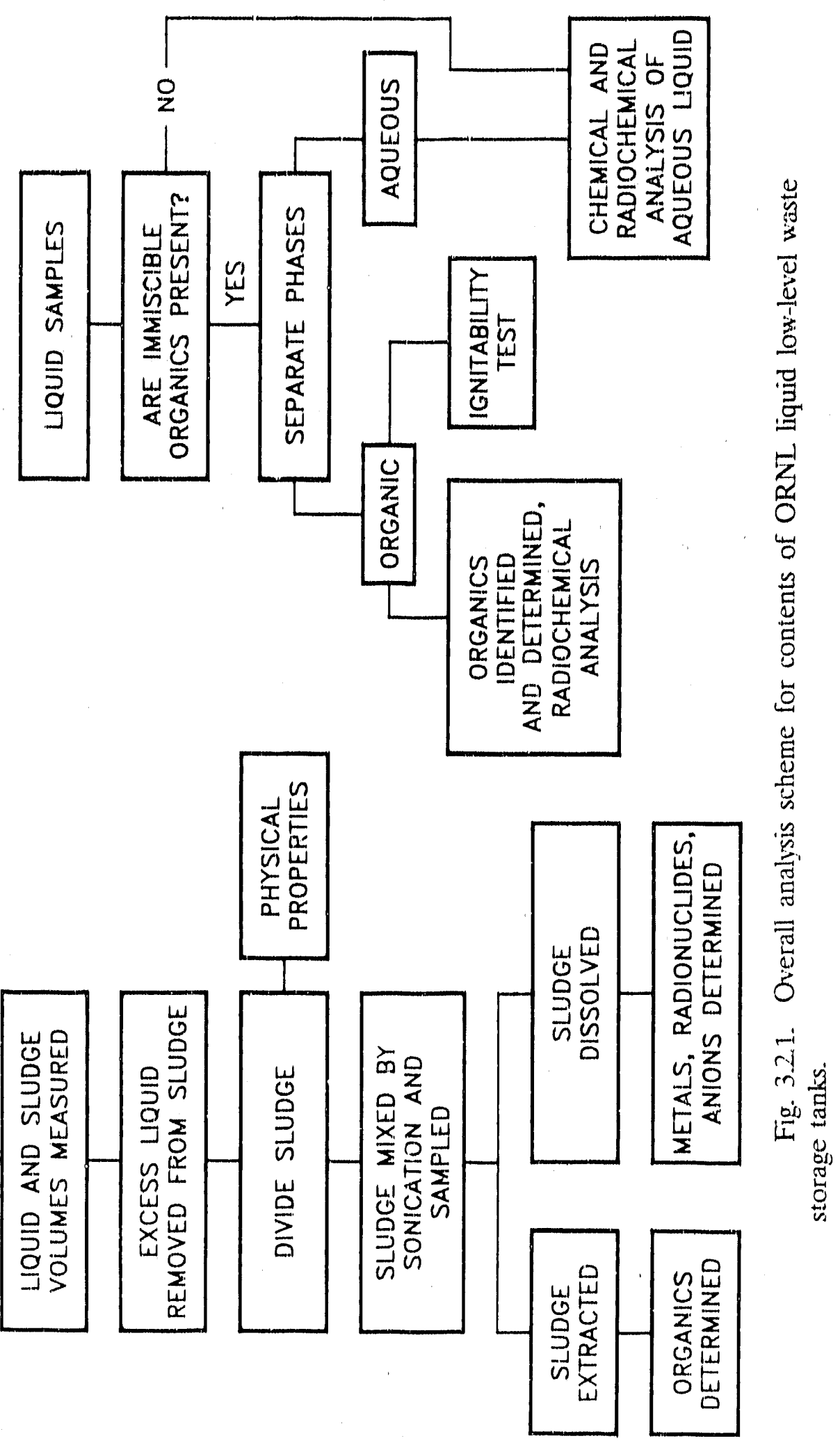


retained for possible future use. Metals, radionuclides, and total organic cartbon were determined on aliguots or extracts of the sonicaled sludge. Sludge samples from three lanks were analyzed for organic compounds.

Detrils of the analytical procedures are presented in Appendix B. The EPAapproved analytical procedures were followed, as much as possible, in analyses for RCRA and organic compounds. Generally, modifleations of procedures from the EPA guide, T'est Methods for Evaluating. Sollid Waste (SW-846) were used, ${ }^{6}$ Some modifications to the standard procedures are necessary because of the high radiation levels, high salt content, and generally complex chemical matrices in the samples. Procedures for the other analyses were selected from the ORNL Analytical Chemistry Division methods or modilied EPA methods ${ }^{6,7}$ based on the sumple characteristles and type of information needed.

\subsection{QUALITY ASSURANCE}

Quality assurance during tank sampling activities was maintained primarily through the use of specilie procedures for the sampling crew to follow. These procedures provided step-by-step instructions for the collection, labeling, and shipping of each sumple. All liekd data, such as liquid and sludge depths, sample identification numbers, and lield surveys were recorded on data forms 10 ensure an aceurate aceount of the sampling activities. Chain-of-custody forms were used to track individual samples from their collection point 10) the analytical laboratory. An independent survellanec by the Quality Assurance Specialist verified that sampling procedures, chain-ol-custody criteria, ladiation protection, and operator training were in compliance with all written procedures.

Quality assuranee during sample analyses is more fully described in Appendix B of this report. A traveler composed of a chain-of'-custody form and a request for analytical services form accompanied every sample, subsample, or extract when transferred between analytical laboratorics.

\subsection{REFERENCES}

1. ORNL Environmental Protection Manual, Procedure EPM-18,0, "Liquid Waste Disposal," staff' of the Department of Environmental Management, Oak Ridge National Laboratory, Oak Ridge, Tonnessec. 
2. Procedures and Practlecs Lor Radiation Protection. Honlth Physics Munual, Onk Ridge Natlonal Laboratory, Oak Ridge, Tonnessed.

3. L. D. Kalsor, Oak Ridge National Laboratory, porsonal communications, April 20 and May 24, 1988.

4. R. N. Ceo, A. J, Mattus, and J. T. Shor, Oak Ridge National Laboratory, personal communication, September $28,1989$.

5. F, J. Porctz, B. R. Clark, C. B. Sontt, and J. B. Borry, Characterization of Low. Level Liquid Wastes at the Ouk Ridge National Laborentory, ORNL/TM-10218, December 1986.

6. U.S. Environmental Protection Agency, Test Malerials for Evalunting Solid Waste, SW-846, 3rd ed., Olfice of Waste and Emergency Response, Washington, D.C., November 1986.

7. U.S. Environmental Protection Agency, Methods for Chemical Anulysis of Wencer and Wastes, EPA-6(k)/4-79-()20, Revised March 1983. 


\section{SUMMARY OF RESUL'IS}

\subsection{SAMPLE COLLLCTIION AND GENERAL. CHARACTERISTITSS}

\subsubsection{Sample Collection}

Liguld and sludge samples were collecled f'rom six of the MVSTs (lanks W-24 through $W-28$ and W-31) and iwo ol' the consentrate storage tanks (W-21 and W-23) all the evaporntor serviec fincility hy the methods described in Sect, 3.1 and Appendix E. The aceess is a 3.in.-diam pipe that penetrates the lank from the roof of the vall which houses the tanks and provides radiation shiclding. A Markland sludge level dotector was used to locate the air-liguid and liguid-sludge interfieces. Liquid samples wese colleceted at three levels - orte-third, onc-hall, and two-thirds of the depth of the supernate, except in the case of tank W-23 where the liguid layer was shallow and only the one-hall' level sample was collected. Samples representutive of a "core" of sludge were collected from seven ol" the tanks. 'Tank W-27 contained a layer ol' hard sludge which plugged the sumpling device: a sample ol' the underlying solt sle'dge was not obtained. Because only sludge directly under the access port can be sampled, the sludge samples may not be representative of other locations in the tank and should be considered merely an indicator of the tank contents.

Liquid sumples were collected from tanks W-29 and W-30) using the pump module (Isolock) sumpler (see Sect, 3.1.5 and Appendix F). These tanks were modified for the Emergency Avoidance Solidilication Campaign and cannot be aceessed by the general procedure used for the other tanks. Becialuse of the modilieations, it is not possible to simple the sludge in these lanks.

A total of 28 liquid samples and 21 sludge samples were collected and transported to the High Radiation Level Analytical Laboratory (Building 2026). One sample each from lanks W-29 and W-30 was archived, since the sampling of these wastes was in support of a second solidificution cumpaign which is being planned for FY 1991.

Field sampling data, including the profile of the tank contents and a comprehensive listing of the samples collected (date of collection, sampling location, and radiation level) are given in Appendix A. The field dala are from the perspective of the sampling crew standing on the pad over the tank, with distances moasured from the llange on the aceess pipe down into the lank. The estimated ractiation doses to personnel from field sampling activilies are presented in Tuble A.4. 


\subsubsection{Tonoral Charactoristics}

General characteristics of' the sumples are summarlaced in 'l"able 4.1.1. All of' the licguid samples appearod to be single phase and rangesd from pule to docep yellow whth litile, If any, turbidlly, Dose rates (lickd survey) on contact with the lull $25($ ) m m sample fars ranged from (0.1 to $0.5 \mathrm{R} / \mathrm{h}$ except lor the samples from lank W.26, which mensured 1.2 R/h. Most of the liguld samples eould be transperted and slored in lead pigs. Henwever, the sumples from W-26 wore transportod in a shicklod carrier and unloudad into a hot cell

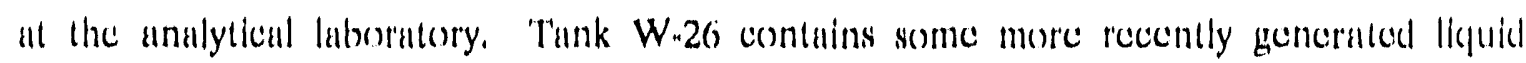
waste, which was transfered from the evaporator service facillity an the summer of 1989.

Most of the sludges could be sampled with the solte-sludge sumpler. Tanks W-27 and W-31 contained layers of "hard" sludge; samplers with hard culling edges were usted to eollect these sumples. Dose rates (lield survey) for the wet sludge sumples ranged from 1 lo $2.8 \mathrm{R} / \mathrm{h}$ lor a $\sim 250 \mathrm{~mL}$ simple. Radiation flelds were enensiderably higher neur small samples dried in the laboratory. Dose rates of up to $50 \mathrm{R}$ per hour per gram were observed for dried samples. The increased dose rate was primurily due lo bela particles from ${ }^{9()} \mathrm{Sr}$ and ${ }^{90} \mathrm{Y}$, which hrit been altenuated by the wet sludges. Sludge samples were transported in a shiclded carricer and unloaded into a hot cell; small subsumples were removed for analysis in radiochemical hoods and glove boxes. Every effort was made lo avoid handling dried samples in order to reduec both exposure and spread of contamination.

The sludges are not homogeneous and vary in eonsistency and color. Subjective observations by the sampling crew (c.ge, the effort reculired to push the sampler into the sludge) and by the annlysts who worked with the samples in the laboratory are given in Table 4.1.1. For example, the sampling crew thought that most of the sludge in tanks W-24 and W-25, except for the thin layer of "mud" at the boltom, could probibly be pumped with a peristaltic pump. The eonsistency of soft sludges that had been sonicuted ranged from "similar to prepare d mustard" to "like peanut butter wilh gritty particles" (sample W26-S). The "hard" sludge from tank W-27 had the consistency of a hard mud and the appearance of concrete pieces mixed with mud or clay; it was too stifl' to sonicalc. The hard sludge from lank W-31 has the appearance of mud or clay with a linle grit.

In a separate study, physical properties tests were conducted on alicyuots of four of the solt sludge samples collected in this campaign. "The sludge from the bottom of tank W-26 had the highest viseosity of the four samples that were tested. 


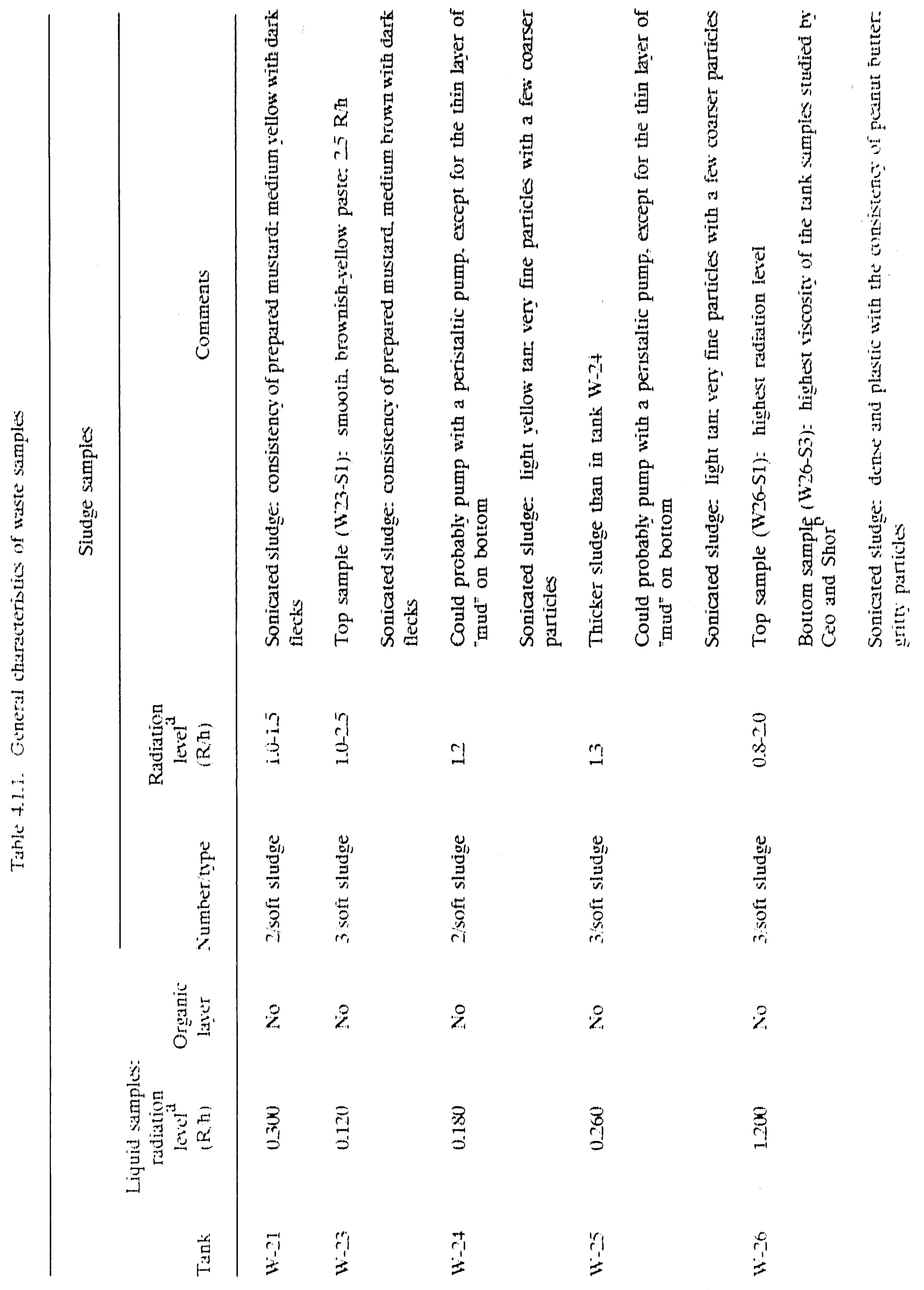




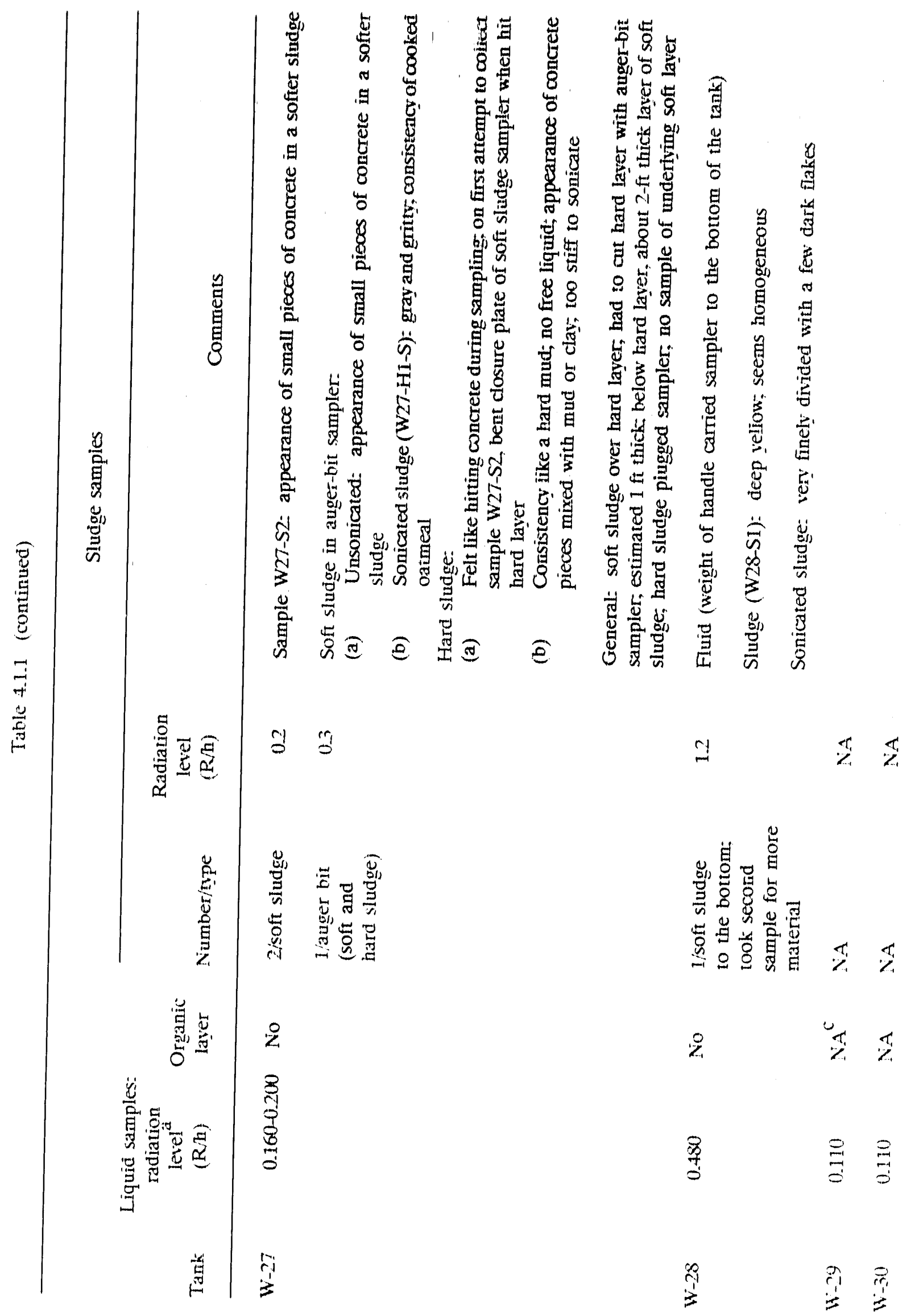




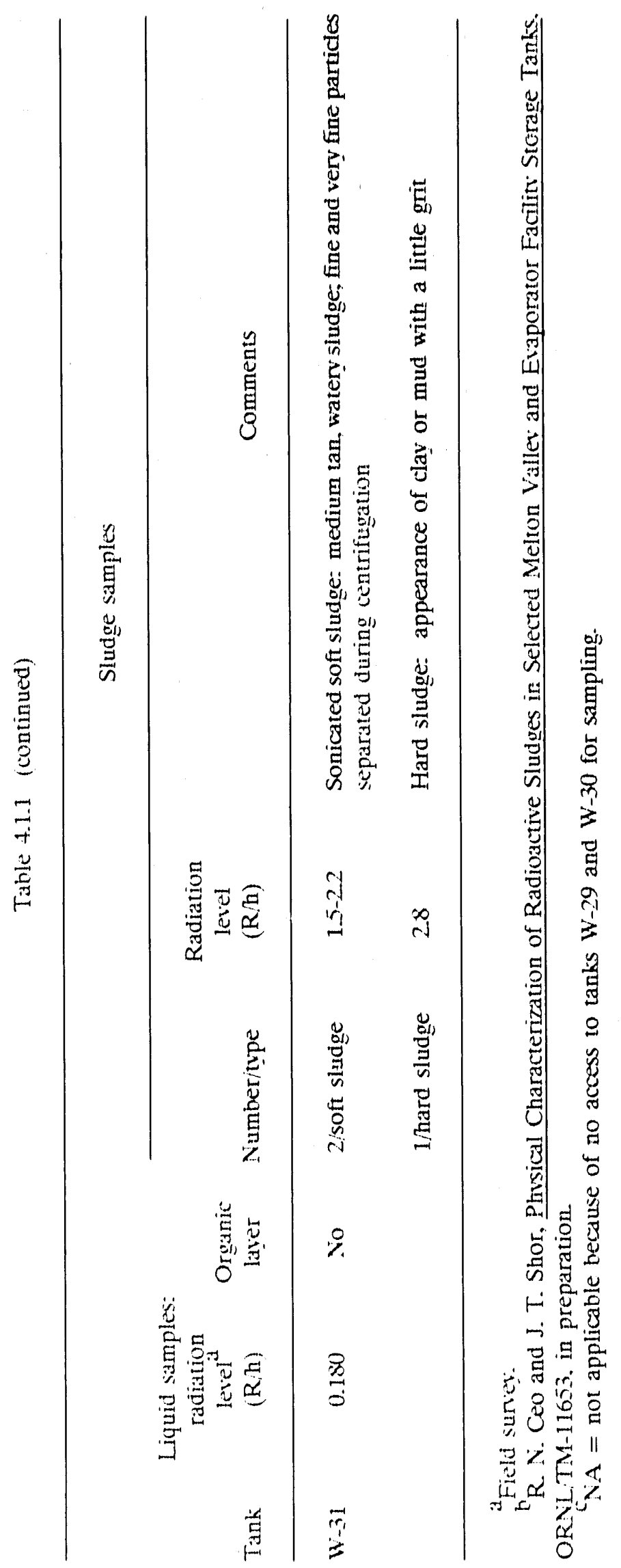




\subsubsection{Checks for Water-Insoluble Organic Liquids}

There was no indication of organic liquids/solvents that are immiscible with the aqueous liquid in any of the tanks or samples. A column of liquid was collected at the airliquid interface and examined visually in the field. The interface was clear in all cases. No organic layer lighter than the aqueous phase was observed in any of the tanks, and no immiscible or stratified liquid layers were detected with the Markland instrument. There was also no indication of any water-insoluble organic liquids in the sludge samples. No immiscible liquid phases were observed when sludge samples were centrifuged as a step in deterwaning bulk densities. No "oily" droplets were seen on the walls of the PVC tubes or funnels when the sludge samples were transferred to jars, or on the walls of the analytical glassware/plastic ware.

\subsubsection{Inventory of Radioactive Liquid Wastes and Sludges}

Profiles of the tank contents are presented in Table 4.1.2. The dimensions are measured from the tank bottom and are derived from the sampling data presented in Appendix A. A typical MVST contains a bottom layer of sludge solids, which is about $4 \mathrm{ft}$ deep in the center of the tank below the access pipe, and a top layer of supernatant liquid about $6.5 \mathrm{ft}$ deep (see Fig. 4.1.1). Sludge depths in the tanks ranged from about 19 to 68 in. The MVSTs are filled essentially to their working capacity; tanks W-21 and W-23 at the evaporator service facility are about half full. Tank W-27, which has a somewhat different profile, contains (1) a layer of soft sludge on the bottom; (2) a layer of hard sludge, estimated to be $1 \mathrm{ft}$ thick, immediately above the bottorn layer; and (3) a layer of soft sludge over the hard sludge (Fig. 4.1.1).

The location of the top of the sludge solids layer was determined from the height of the settled solids phase in the sample collected at the liquid-sludge interface (measured in the analytical laboratory) and the location in the tank where the sample was collected. Some samples had a slightly cloudy layer over the sludge which was detectable by the Markland instrument (see Appendix A), but visually the amount of suspended solids was very small. This layer is included in the liquid inventory in this discussion.

Estimates of the quantities of radioactive liquid wastes and sludges stored in six of the MVSTs (tanks W-24 through W-28 and W-31) and two evaporator storage tanks (W-21 and W-23) are given in Table 4.1.3. The calculations assume horizontal tanks with ellipsoidal heads that coincide with the drawings and American Society for Testing and 
Table 4.1.2. Profiles of tank contents ${ }^{a, b}$ (measured from tank bottom)

\begin{tabular}{|c|c|c|c|}
\hline \multirow[b]{2}{*}{ Tank } & \multicolumn{3}{|c|}{ Height of waste (in.) } \\
\hline & $\begin{array}{l}\text { Total waste } \\
\text { (liquid and } \\
\text { sludge) }\end{array}$ & $\begin{array}{c}\text { Top of } \\
\text { sludge solids } \\
\text { layer }\end{array}$ & $\begin{array}{c}\text { Top of } \\
\text { hard sludge }\end{array}$ \\
\hline W-21 & 65 & 26 &. \\
\hline W-23 & 62 & 52 & . \\
\hline W-24 & 127 & 44 & - \\
\hline W-25 & 127 & 68 & - \\
\hline W-26 & 120 & 49 & . \\
\hline W-27 & 125 & 54 & $38^{\mathrm{d}}$ \\
\hline W-28 & 131 & 19 & - \\
\hline W-31 & 122 & 27 & 5 \\
\hline
\end{tabular}

anventory in MVSTs as of December 5, 1989; inventory in tanks W-21 and W-2.3 as of Janaury 31, 1990. No waste transfers at MVSTs during period September 1, 1989 . January 31, 1990.

${ }^{b}$ Derived from sampling data in Appendix A, Table A.1.

${ }^{c}$ Based on height of settled sludge solids phase in the PVC sampling lube; sample collected at the supernate/sludge interface.

${ }^{\mathrm{d}}$ Hard-sludge layer estimated to be about 1 ft thick. Underlying layer of soft sludge about 2 fit thick. 


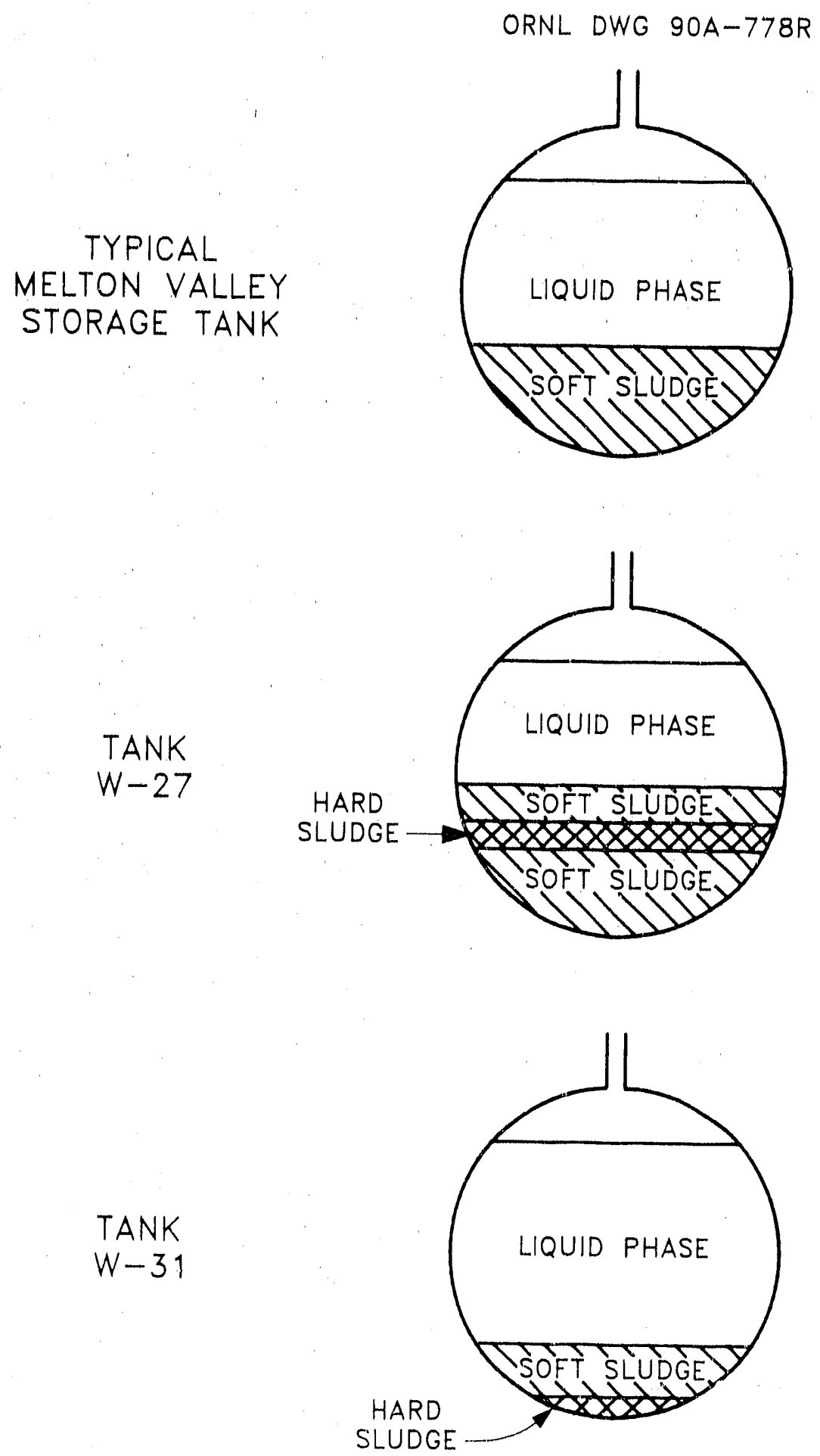

Fig. 4.1.1. Protile of wastes in the Melton Valley Storage Tanks. 


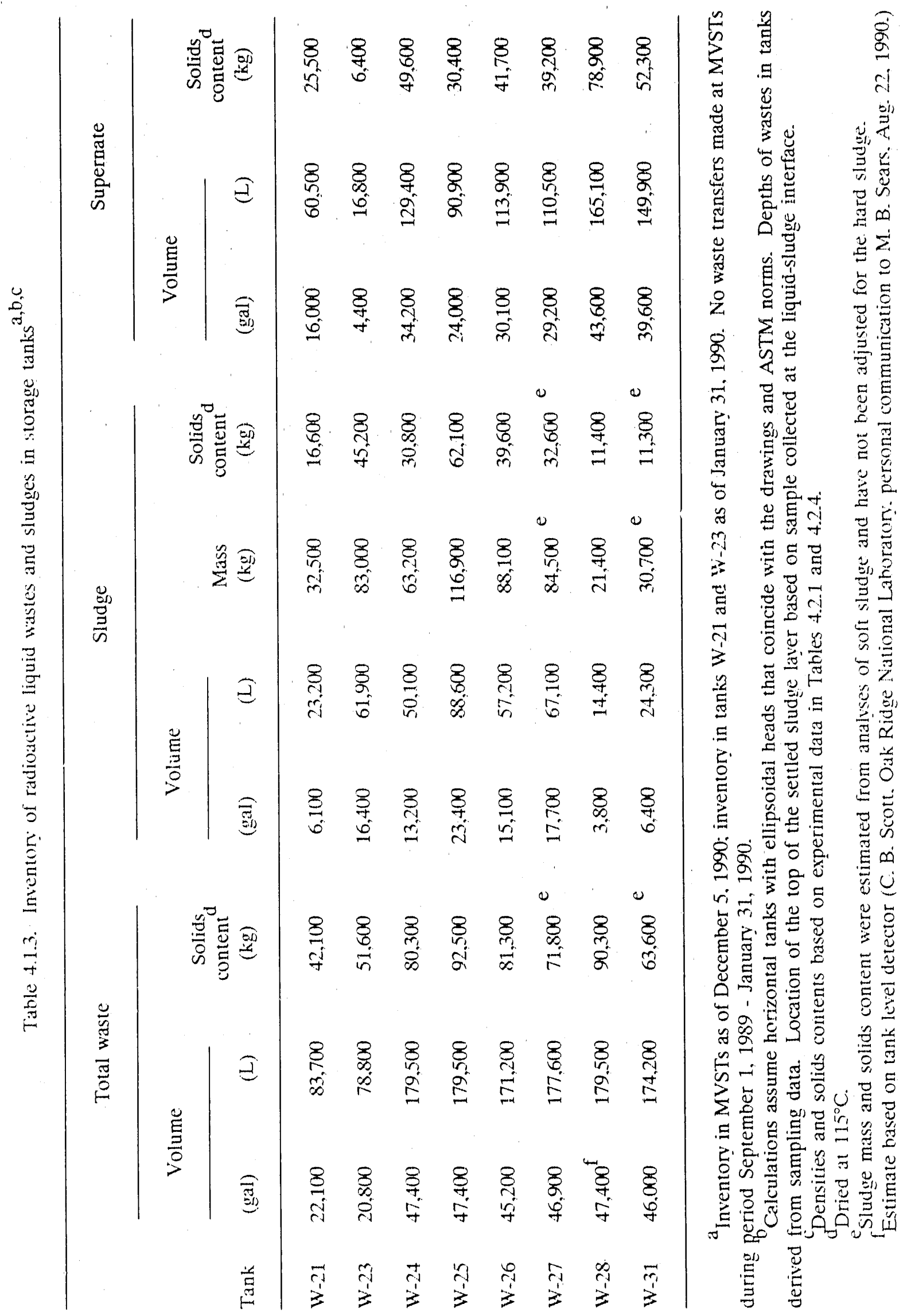


Materials (ASTM) norms. The heights of the sludge and liquid phases are based on the sampling data (Table 4.1.2), and the densities and solids contents used in the calculations are derived from the experimental data in Sect. 4.2, Table 4.2.1, and Table 4.2.4. The solids contents were determined for waste samples dried at $115^{\circ} \mathrm{C}$.

\subsection{INORGANIC, PHYSICAL, AND RADIOCHEMICAL CHARACTERISTICS}

\subsubsection{Analytical Results}

Samples of the supernatant liquids and composite samples of the sludges in the waste tanks were analyzed for major constituents, radionuclides, total organic carbon, metals listed as hazardous under RCRA, and general waste characteristics. Details of the analytical work, including sample preparation, analytical methods, and quality control, are described in Appendixes $\mathrm{B}$ and $\mathrm{C}$.

The analytical data for the liquid and sludge samples are presented in Tables 4.2.14.2.3 and 4.2.4, respectively. The sample identification code includes the tank identification (e.g., W21, W23, etc.) followed by a hyphen and a phase identification ( $\mathrm{L}=$ liquid; $\mathrm{S}=$ soft sludge; $H=$ hard sludge). The code may contain an additional number to identify the location/depth in the tank at which the sample was collected. (The location/depth information is given in Appendix A.) The less than symbol (<) in Tables 4.2.1-4.2.4 means that the constituent was not defected and the limit of detection is reported. Data in parentheses (e.g., Ag in the sludges) are of questionable quality due to poor spike recovery. The initialisms used in the tables are defined as follows:

TDS - total dissolved solids,

TS - total solids,

IC - inorganic carbon,

TC - total caubon,

TOC - total organic carbon.

\subsubsection{Overall Trends and Solubility}

The supernatant liquid wastes in the storage tanks (except tank W-21) are high$\mathrm{pH}$ (typically 11 to 13) sodium/potassium nitrate salt solutions. The sludges contian significant levels of carbonate, and some tank solutions contain dissolved carbonate ions. While the alkali melals ( $\mathrm{Na}, \mathrm{K}, \mathrm{Cs}$ ) are soluble, most of the other metals present in the wastes are precipitated to the sludge phase. With the exception of the alkali metals and 
I'alile 4.2.1 (conlinued)

\begin{tabular}{|c|c|c|c|c|c|}
\hline \multicolumn{2}{|c|}{ Chamacteristic } & $W 26.1 .2$ & $W 27.1 .2$ & $W 2 x-1.2$ & W.31-1.2 \\
\hline \multicolumn{6}{|c|}{ Physical proportics and iniscollancous data } \\
\hline ITSS & $(\mathrm{mg} / \mathrm{mi})$ & 369 & 3.58 & 48,5 & .351 \\
\hline I's & $(\mathrm{mg} / \mathrm{mL} \mathrm{s})$ & 360 & 3.55 & 478 & 349 \\
\hline Densily & $(\mathrm{g} / \mathrm{mL} \mathrm{L})$ & 1.2177 & 1.2118 & 1.2852 & 1.207 .5 \\
\hline lc: & $(\mathrm{mg} / \mathrm{l})$ & 2580 & 4.7 & 7.0 & 18.9 \\
\hline $\mathrm{YC}$ & $(m g /)$ & 3860 & 364 & 581 & 40.4 \\
\hline Tro: & $(m g /)$ & 1280 & 3.59 & 574 & 445 \\
\hline \multicolumn{6}{|c|}{ RCXRA metuls } \\
\hline $\mathrm{Ag}$ & $(m g /)$ & 1.2 & $<0,69$ & $<0,64$ & $<0,(i)$ \\
\hline As & $(m g / l)$ & $<3.7$ & $<3,7$ & $<3.7$ & $<3.7$ \\
\hline$B a$ & (mg/.) & 0,20 & 4.1 & 5.8 & 3.5 \\
\hline Cd & (myll) & 4.5 & 0.12 & 0.51 & $<0.12$ \\
\hline $\mathrm{Cr}$ & $(\mathrm{mg} / \mathrm{l})$ & 1.8 & 2.8 & 0,38 & 0.0 \\
\hline $\operatorname{lgg}$ & $(m g / l)$ & $<0,08$ & $<(1), 048$ & 0,14 & 0.15 \\
\hline $\mathrm{Ni}$ & $(\mathrm{mg} / \mathrm{l})$. & 8.2 & $<0.38$ & 1.4 & $<0.38$ \\
\hline ?h & $(m g /)$ & 3.2 & $<2.1$ & $<2,1$ & $<2.1$ \\
\hline Sc & $(m g / l)$ & $<4.7$ & $<4.7$ & $<4.7$ & $<4.7$ \\
\hline 'il & $(m g / l)$ & $<1.4$ & $<1.4$ & $<1.4$ & $<1.4$ \\
\hline \multicolumn{6}{|c|}{ Process motals } \\
\hline $\mathrm{AI}$ & $(m g / l)$ & 4.8 & $<4.2$ & 5.2 & 4.2 \\
\hline$B$ & $(m g / l)$ & 3.9 & 0,67 & 0.3 .5 & 0.20 \\
\hline$C$ & $(m g / l)$ & 20 & 2600 & 7800 & 79 \\
\hline$C_{0}$ & $(m g / t)$ & $<0.57$ & $<0.57$ & $<0.57$ & $<0.57$ \\
\hline $\mathrm{lec}$ & $(m g /)$. & $<2.6$ & $<2.6$ & $<2,6$ & $<2.6$ \\
\hline$k$ & $(m g / l)$ & 51000 & 8.500 & $26000)$ & 9500 \\
\hline $\mathrm{Mg}$ & (mg/l.) & 3.5 & $<1.3$ & 1600 & $<1,3$ \\
\hline $\mathrm{Ni}$ & $(m g / l)$ & 68000 & $900(0)$ & $96(10)$ & $940(0)$ \\
\hline $\mathrm{Si}$ & (mg/l.) & 11.9 & $<1.0$ & $<1,0$ & 8.57 \\
\hline $\mathrm{si}$ & $(\operatorname{mg} / 1)$ & $<0.74$ & 18 & 6.5 & 12 \\
\hline li & $(\mathrm{mg} / \mathrm{l},)^{\prime}$ & 10 & $<2.2$ & $<2.2$ & $<2.2$ \\
\hline U & $(m g / l)$ & 11.30 & $<0.1$ & $<0,1$ & 0.2 .5 \\
\hline \multicolumn{6}{|l|}{ Anions } \\
\hline Chloride & (M) & 0.090 & 0.071 & 0.14 & 0.07 .3 \\
\hline liluoricle & $(\bar{M})$ & $<0.026$ & $<0,026$ & $<0,026$ & $<0.1126$ \\
\hline Nitrate & $(\overline{\mathrm{M}})$ & 3.29 & 4.52 & 5.97 & 4.52 \\
\hline Phosphats: & (프) & $<0.053$ & $<0.0 .53$ & $<0.05 .3$ & $<0.115 .3$ \\
\hline Sullate & $(\bar{M})$ & $<0.052$ & $<0.052$ & $<0.0152$ & $<0.0152$ \\
\hline \multicolumn{6}{|l|}{ Alkalinity } \\
\hline$\mu$ & & 11.2 & 11.8 & 9.1 & 11.7 \\
\hline () 11 & $(\mathrm{M})$ & $<0.01$ & 0.01 & $<0.01$ & $(0.11)$ \\
\hline$(0)$ & $(\underline{M})$ & 0.20 & $<0.01$ & $<0 .(01$ & $<0 .(1) 1$ \\
\hline $1100_{3}$ & $(\bar{M})$ & 0.02 & $\leqslant 0.01$ & $<0,(0)$ & $<0.01$ \\
\hline \multicolumn{6}{|c|}{ Beta/gamma cmillers } \\
\hline Gross alphai & $(13 q / m l)$ & $1.03 \mathrm{c}+0.3$ & $<1.0 c+100$ & $4.40 c+01$ & $<1.00(0+00)$ \\
\hline Ciross belia & $(B \mathrm{c} / \mathrm{mL} L)$ & $2.2(k+1)$ & $3.30 c+0.5$ & $9.80 \mathrm{c}+0.5$ & $3.58 \mathrm{c} \cdot+1.5$ \\
\hline 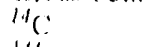 & $(B(y / m l)$ & $1.23 c+02$ & $1.81 c+02$ & $1.67 c+02$ & $1.120+12$ \\
\hline $1.4 \mathrm{C} c$ & $(B \mathrm{~B} / \mathrm{n} 1 \mathrm{l})$ & $<2.3 c+0.3$ & $<7.5 c+02$ & $<1.8 c+0.3$ & $<7.86+10_{2}^{2}$ \\
\hline${ }^{\prime \prime \prime)}(n)$ & $(B(y / m l)$. & $1.220+04$ & $3.09 c+02$ & $8.72 c+0.3$ & $3.230+102$ \\
\hline $1.14 \mathrm{C}$ & $(\mathrm{Bc} / \mathrm{ml})$ & $1.31 c+04$ & $1.61 \mathrm{c}+0.3$ & $1.0(x+04$ & $5.011 \cdot+(1.3$ \\
\hline${ }^{1.17} \mathrm{C} \mathrm{s}$ & $(B q / m l)$ & $2.07 \mathrm{e}+106$ & $2.160+0.5$ & $5.6110+0.5$ & $22 \%+05$ \\
\hline $1.521: 4$ & $(\mid B(j / m L)$ & $<2.10+02$ & $<1.1 c+(12$ & $1.67 c+03$ & $<0.3 c+(1)$ \\
\hline $1.541: u$ & $(B \mathrm{~g} / \mathrm{ml} l)$ & $<2.4 c+02$ & $<6,6 c+01$ & $7.37 e+02$ & $<(1.7 e+1)$ \\
\hline $1.51: \mathrm{L}$ & $(B(1 / m))$ & $<1.2 \mathrm{c}+03$ & $<4 .(x+1) 2$ & $<9.3 c+(02$ & $<4.20+02$ \\
\hline 31 & $(B \mathrm{~g} / \mathrm{ml})$. & $6.18 c+02$ & $2.0 \%+02$ & $1.1 \%+02$ & $1.560+02$ \\
\hline${ }^{0.5} \mathrm{Nh}$ & $(B y / m L)$ & $<1.4 c+02$ & $<3 .(k+0) 1$ & $<1.2 c+12$ & $<3,3 c+01$ \\
\hline$\left\|x_{1} \mid\right\|_{1}$ & $(\mathrm{Bc} / \mathrm{ml} \mathrm{l})$ & $<2.8 \mathrm{c}+0.3$ & $<1.10+0.3$ & $3.02 \mathrm{c}+0.3$ & $<1.10+10.3$ \\
\hline HIs $\mathrm{Sr}$ & $(\mid B C / / 111)$ & $4.90 e+02$ & $5.57 c+04$ & $1.75 c+0.5$ & $7.3860+0.1$ \\
\hline $45,7 . r$ & $(\mathrm{Bc} / \mathrm{ml})$ & $<2.7 c+12$ & $<5.20+(01$ & $<2.20+(12)$ & $<5,76+011$ \\
\hline \multicolumn{6}{|c|}{ Alpha comitters } \\
\hline $\operatorname{Th} U$ & $(B \mathrm{c} / \mathrm{ml} \mathrm{L})$ & $3.60 \mathrm{cc}+01$ & . & . & . \\
\hline 2311. & $(|3 y / m|)$ & $9.20 x+02$ & . & - & . \\
\hline$\therefore B$ & $(B \mathrm{~g} / \mathrm{ml} \mathrm{L})$ & $1.00 x+0.1$ & . & . & . \\
\hline 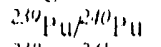 & $(\mid B(y / m \mid)$ & $1.00 c+01$ & - & - & . \\
\hline $2 \mathrm{p}_{\mathrm{p}} \mathrm{u} \mathrm{f}^{2} \wedge \mathrm{m}$ & $(B(\mathrm{~g} / \mathrm{ml})$ & $<1.5 c+0)$ & . & . & . \\
\hline
\end{tabular}




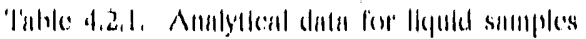

\begin{tabular}{|c|c|c|c|c|c|}
\hline \multicolumn{2}{|l|}{ Chatactertstic } & W21.1.2 & W2:11.1 & W.4.I.2 & Was.1.2 \\
\hline \multicolumn{6}{|c|}{ Mhysloal propertics and milscollancouls data } \\
\hline TIST & $(1111 / 1111)$ & .39 .3 & 381 & .377 & $.3 .1 \times$ \\
\hline 'IS'S & $(m 1 / 1 m 1)$ & 421 & .38 .1 & $3 \times 3$ & .3 .31 \\
\hline 1)entily & $(\mathrm{H} / \mathrm{ml})$ & $\mid .2301$ & 1.2423 & $1.23 .1 \mathrm{~K}$ & 1.2() 18 \\
\hline IC & $(m g / 1)$ & $<1,0$ & 8.3.11) & (1)10 & $1.5,8$ \\
\hline 'I' & $(m g / l)$ & 571 & $95(0)$ & 2400 & 478 \\
\hline ' $x(x)$ & $(m y / l)$ & 571 & $116(0)$ & 489 & 462 \\
\hline \multicolumn{6}{|c|}{ RCCIRA motuls } \\
\hline$A g$ & $(m g / l)$. & 1.2 & $<(0,44$ & $<0.60$ & $<(1,(1)$ \\
\hline As & $(111 g / /)$ & 3.8 & $<3.0$ & $<3.7$ & $<.3,7$ \\
\hline B:1 & $(m 1 / / l)$ & 25 & $<(1) .19$ & 0.24 & 3.2 \\
\hline ( i) & $(m 11 / 1)$ & 2.0 & 1.7 & 0.22 & $<0.12$ \\
\hline$(\mathrm{l})$ & $(m p / l)$ & 27 & 0.42 & 3.1 & 19 \\
\hline $118:$ & $(m g / l)$ & 0.42 & 0.07 & 0.044 & 0.015 .1 \\
\hline $\mathrm{Ni}$ & $(m g / l)$ & 1.5 & 3,0 & $<1.34$ & 0.15 \\
\hline \% & $(1114 / 1)$ & 7.1 & 2.7 & 0.7 & $\because 2.1$ \\
\hline Sis & $(m g / 1)$ & $<2.3$ & $<2,1$ & $<4.7$ & $\lessdot 4.7$ \\
\hline 11 & (III)/l) & $<(1,0) 4$ & $<0.94$ & $<1.4$ & $\because 1.1$ \\
\hline \multicolumn{6}{|c|}{ Proness motals } \\
\hline AI & $(m p / l)$ & $<1.2$ & 1.8 & 46 & $<42$ \\
\hline H & $(111 \mathrm{~g} / \mathrm{l})$, & 1.0 & 10 & 01.95 & (1.01) \\
\hline ( 'il & $(m g / /)$ & 2.3011111 & 18 & 7.2 & 280 \\
\hline$(\because)$ & $(m y / l)$ & & $\cdot$ & 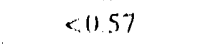 & 60.57 \\
\hline 10 & $(m g / 1)$ & 2411 & 0.70 & $\therefore 2.6$ & 52.4 \\
\hline ki & $(m g / 1)$ & $2(x)(10)$ & $78(x)$ & 1101101 & 17000 \\
\hline N!: & $(\mathrm{mg} / \mathrm{l})$ & $.5(10)$ & 3.4 & $\because 1.3$ & $<1.1$ \\
\hline Nil & (III)/1.) & 010000 & 820100 & $10(0) 000$ & $78(1)(1)$ \\
\hline$S i$ & (mglli) & $<1$ & $<1$ & 245 & $\therefore 1$ \\
\hline Sir & $(m+1)$ & $(f, 1)$ & 0.40 & $<0.74$ & 2.1 \\
\hline 'Th & $(m g / 1)$ & 95.1 & 1.5 .8 & 62.2 & $\therefore \ldots$ \\
\hline 11 & $(m p / l)$ & 7511 & 17 & 9.4 & $\therefore 0.10$ \\
\hline \multicolumn{6}{|l|}{ Anions } \\
\hline ('hloritile & (M) & 0.05 .9 & 0.10 & 0.07 .3 & $0.071)$ \\
\hline I'Inoride & (1) & $<1) .11 .53$ & $<0.0153$ & $\ll(0.026$ & $<0 .(1)(1)$ \\
\hline Nilliale & $(\underline{\mathrm{M}})$ & 5.0 & 3.23 & 4.19 & 4.111 \\
\hline l'mspharle & $(\bar{M})$ & $<0.10 .5 .3$ & $<0.115 .3$ & $<0.0 .53$ & $<0.11 .9:$ \\
\hline Sullitle & (M) & $<0,11,22$ & $0 .(181$ & $<0.052$ & $<0.015_{2}^{\circ}$ \\
\hline \multicolumn{6}{|l|}{ Alkulinity } \\
\hline$\mu 11$ & & 0.56 & 12.8 & 1.3 .1 & 12.5 \\
\hline 111 & (M) & (1).1) & - & - & . \\
\hline (1)11 & $(\underline{M})$ & - & 0.15 & 0.29 & 0.116 \\
\hline$(1), \cdots$ & (M) & . & 0.70 & 0.15 & $<0 .(1)$ \\
\hline $11(1)_{1}$ & (M) & . & . & $<0 .(01$ & $<0.111$ \\
\hline \multicolumn{6}{|c|}{ Beli/gamma emillers } \\
\hline Giruss illphit & $(\mid 3(\mid / 111)$ & $2.1 .10+0.3$ & 8.2()$+101$ & $50(0)+00$ & $2.110(1000$ \\
\hline liruss hellit & $(\mid B(p / 111)$ & $424+0.5$ & $4.120+115$ & $2.304+0.5$ & $3.920+1.5$ \\
\hline 111 & $(B(y / 1) 1)$ & $<1 .(x+1)$ & $6.35 c+11)$ & $7.870+102$ & $32 \%+(2)$ \\
\hline $1+14 c^{\circ}$ & $(B(y / \mid 11))$, & $<1.5 c+11.3$ & $41.6 c+183$ & $<7.4 c+122$ & $-1.30+103$ \\
\hline (1) $(1)$ & $(13 y, m l)$ & $8.50)(+0.3$ & $6.210+12$ & $3.24+02$ & $1.886 \cdot+(0.3$ \\
\hline 13.1 ('s & $(13(4 / m))$, & $5.120+0.3$ & $4.6 .3 x+0.3$ & $1.340+0.3$ & $3.776+(1,3$ \\
\hline $131 !$ & $(B y / / n])$, & $3.1 \%+05$ & $4.36 x+0.5$ & $2.210+015$ & $327 c+0.5$ \\
\hline $191: 11$ & $\left(B\left(y^{\prime} / m\right)\right)$ & $3.310+04$ & $<2.10+1)_{2}$ & $<3.20+102$ & $<1 .(x+0)$ \\
\hline $151: 4$ & $(\mid 3(y / a 11))$ & $1.61 x+04$ & $<1.10+1)^{2}$ & $<0,(0)+(0) 1$ & $<1.20: 100$ \\
\hline 1591.11 & $(13(p / m i))$ & $5.220+103$ & $=8.50+102$ & $<4.00+112$ & $<(1,90,+1)$, \\
\hline 11 & $(|3 c| / 111 \mid)$ & $3.506+02$ & $1.1 \%+102$ & $3.080+02$ & $3.15 \cdot 162$ \\
\hline NII & $(\{3 y / m\})$ & $<1.50+1)_{2}$ & $<1,0 c+1)_{2}$ & $<2.8 c+112$ & $(11,30101$ \\
\hline$l(x) \mid \therefore u$ & $(\mid 3(1 / / n))$ & $1.950+10.3$ & $3.784+10.3$ & $<1.10+10,3$ & $<1.20+103$ \\
\hline M & $(|3 y / / n|)$ & $7.4 x+11.1$ & $4.120+112$ & $9.1 . i+0_{2}$ & $1.950+11.1$ \\
\hline "y & $(B(y / m))$. & $<7.16+11) 3$ & $<1.0 c+1)^{2}$ & $-5.16 \cdot 1) 2$ & $-120+0 !$ \\
\hline \multicolumn{6}{|c|}{ Alphia conillers } \\
\hline 11 & $(\mid B(y / 111))$. & $6.816 \cdot+101$ & $4.11(x+101)$ & - & \\
\hline$\therefore$ & $(\mid k, y / 111\})$ & $3.51 x+112$ & $0.000+00$ & & . \\
\hline$\therefore p_{1}{ }^{\prime \prime} p_{1}$ & $(\mid k(y / 111))$ & $6.2(k+1) 1$ & $0.00(10+100)$ & & : \\
\hline$\therefore m^{2}$ & $(\mid B y / n 1)$ & $2.110+112$ & $3.4(x+0)$ & . & \\
\hline "'lin & $\left(|3| v^{\prime}(u)\right)$ & $1.150+63$ & $4.00(10+100)$ & & \\
\hline
\end{tabular}




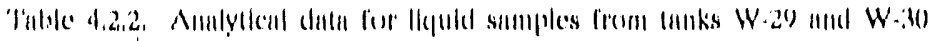

\begin{tabular}{|c|c|c|c|c|c|c|c|}
\hline \multicolumn{2}{|c|}{ Chandeleristic: } & W2II.1.1 & W2Y.1.2 & W2Y.1.4 & $W: 31) \cdot 1.1$ & $W: 3(1.1 .2$ & W.311.1. \\
\hline \multicolumn{8}{|c|}{ 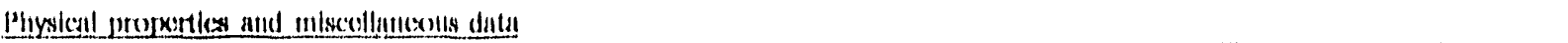 } \\
\hline TOS & $(\mathrm{IIl} / \mathrm{m} / \mathrm{l})$ & .37 .5 & 376 & $.37 \xi_{1}$ & .371 & .377 & .870 \\
\hline Is & $(! 11 y / m 1 m 1)$ & .377 & .374 & 342 & 396 & 301 & $3 \%$ \\
\hline bonstly & $(\mathrm{k} / \mathrm{ilil})$ & 1.2251 & 1.2277 & 1.2294 & 1.2225 & 1.2218 & $|.20| \mid$ \\
\hline Ic & (my/li) & $.1 \%$ & 177 & 4.51 & $60) 2$ & $5 \%$ & $(1)(1)$ \\
\hline l': & $(111 / / 1)$ & 1985 & $1(14.410$ & 8.3 & 801.5 & $(19)$ & $7 \%)$ \\
\hline ' $1(x)$ & $(m y / l)$ & .507 & .561 .3 & 377 & 20.3 & (y) & 109 \\
\hline \multicolumn{8}{|c|}{ 12c IRA metals } \\
\hline Ag! & $(m g / /)$ & $<0,(10)$ & $<(1,(1))$ & $<(1,(1)$ & $<(1,(1)$ & $<(1,6,1)$ & $\because 11,(19)$ \\
\hline$\Delta s$ & $(m g / 1)$ & $<3.7$ & $<3.7$ & $<.1,7$ & $<1,7$ & $<1.7$ & 63.7 \\
\hline 13:1 & $(11 \mathrm{~g} / \mathrm{l})$ & 1.0 & 1.1 & 1.0 & 0,80 & 0.84 & 0.79 \\
\hline (i) & 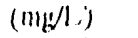 & $(1), 12$ & $<10.12$ & $<11.12$ & $<10.12$ & $<0.12$ & $<11.12$ \\
\hline ( 1 & $(\mathrm{mg} / \mathrm{l})$ & 2.4 & 2.4 & 2.3 & 3,11 & 2.9 & 2.1 \\
\hline $11 g$ & $(\mathrm{mg} / \mathrm{l})$ & $0,(14)$ & 0.08 & $0 .(14)$ & 0.10 & 0.10 & 11.10 \\
\hline $\mathrm{Ni}$ & $(\operatorname{lng} g / 1)$ & $<11.38$ & $\therefore 0.38$ & $<0.38$ & $<(0,18$ & $<0.38$ & $\therefore 11.38$ \\
\hline 16 & $(m g / h)$ & $<2.1$ & $<2.1$ & 2.3 & 3.0 & 2.9 & 2.3 \\
\hline Sis: & $(111 \mathrm{~g} / \mathrm{l})$, & $<4.7$ & $<4.7$ & $<4.7$ & $<4.7$ & $<4.7$ & $<1.7$ \\
\hline 11 & $(m g / h)$ & $<1.4$ & $<1,4$ & $<1.4$ & $<1.4$ & $<1.4$ & $<1,4$ \\
\hline \multicolumn{8}{|c|}{ Proces mouls } \\
\hline AI & $(m g / / 2)$ & 18 & is & 17 & 34 & 3.3 & 34 \\
\hline H & $(m i / l)$ & 0.50 & 0.47 & 0.36 & $(1.49$ & 0.42 & $0.1 ?$ \\
\hline ( & $(m / / 2)$ & 1.1 & 5.5 & 3,6 & 10 & 9.4 & 11 \\
\hline$i v$ & $(111 \mathrm{~g} / \mathrm{l})$ & $\therefore 2.11$ & $\therefore 2.11$ & $\therefore 2.6$ & $<2.6$ & $<2.6$ & $<2,1$ \\
\hline$k$ & $(111 / 1)$ & $10101101)$ & 100000 & $1(10)(0)$ & 9201 & 19400 & 9.100 \\
\hline $\mathrm{N}:$ & (ng/l.) & $\therefore 1.3$ & $\therefore 1.3$ & $<1.3$ & $<1.3$ & $<1.3$ & $<1.3$ \\
\hline $\mathrm{Nil}$ & ( $m g / /)$. & 1100100 & 1101000 & 1100000 & lokocicis & $1010(1)(10)$ & 110110100 \\
\hline $\mathrm{Si}$ & $(\mathrm{mig} / \mathrm{l})$, & $\therefore 1.0$ & $\therefore 1.0$ & $<1.11$ & $<1,0$ & $<1,0$ & $<1.11$ \\
\hline S̀r & $(m y / l)$ & 1.9 & 2.1 & 1.9 & 1.7 & 1.8 & 1.9 \\
\hline $1 \%$ & $(m+1 /)$ & $<1.11$ & $<1.11$ & $\approx 1.0$ & $<1,0$ & $<1.0$ & $\therefore 1.0$ \\
\hline 11 & $\left(m y^{\prime} / 1.\right)$ & 4.5 & 4.3 & 4.3 & 5.5 & 5.8 & 5.1 \\
\hline \multicolumn{8}{|l|}{ Aninus } \\
\hline chloride & (M) & 0.1082 & 0.078 & 0.0182 & $0.117 \mathrm{~K}$ & 0.082 & 0.0178 \\
\hline laturoride & (M) & $<0.1126$ & $<01.1126$ & $<01,026)$ & $<0.1120$ & $<0,020$ & $<0,1126$ \\
\hline Nillatce & (M) & 4.52 & 4.52 & 4.52 & 4.35 & 4.35 & 4.15 \\
\hline l'husplatce & $(\bar{M})$ & $<11.053$ & $<0,055,3$ & $<0.0153$ & $<0,015.3$ & $<0.0553$ & $<0.015 .1$ \\
\hline $\begin{array}{l}\text { Sulliate: } \\
\text { Alkalinity }\end{array}$ & (M) & $<0.015 \mathrm{z}$ & $<0.1152$ & $<10.052$ & $<0.0 .52$ & $<0.0192$ & $<0.0 .52$ \\
\hline$\frac{\text { Alkдा!IIIY }}{p \| !}$ & & 1.3 .11 & 1.3 .11 & 13,0 & $1,3,2$ & 1.3 .3 & $1,3,3$ \\
\hline () 11 & (M) & $0.0(1.4$ & $0.0(0,4)$ & 0.07 .1 & 0.13 & 0.13 & 0.1 .1 \\
\hline ( (1) $:-$ & $(\underline{\mathrm{M}})$ & 0.0 .13 & 0.04 .40 & 0.054 & 0.05 .4 & 0.0152 & 0.0 .52 \\
\hline$H(1) ;$ & (M) & $<0,(1)$ & $<0,01$ & $<0,0)$ & $<0,(0) \mid$ & $<0.01$ & $<(1.01)$ \\
\hline \multicolumn{8}{|c|}{ Bela/ginmma conitters } \\
\hline Ciruss alphis & $(B \mathrm{~Bq} / \mathrm{mul})$ & $<1 .(0 c+0)$ & $<1.00+01$ & $<1,0 c+0)$ & $<1.06+(1)$ & $<1.0(0+0)$ & $<1.0(1) \cdot 01$ \\
\hline Cirriss holia & $(\mid 3 y / m 1)$ & $2.110+0.5$ & $1.98 \mathrm{sc}+0.5$ & $2.040+05$ & $1.97 c+0.5$ & $1.9 .3 c+105$ & $1.920+105$ \\
\hline $11 \mathrm{C}$ & $(\mid 3(y / m 1)$ & $1.43 c+62$ & $7.3 c+111$ & $5 .(x+0) 1$ & $0,8(1+1) !$ & $8 .(x+1)+(1)$ & $1.106+102$ \\
\hline 1116 & $(\mid 3(p / 1111)$ & $<1.40+103$ & $<1.30+0.3$ & $<1.3 c+03$ & $<1.20+103$ & $<1.20+(1) .3$ & $\therefore 1.30+10.3$ \\
\hline$x^{\prime \prime \prime}(x)$ & $(\mid \mathrm{g} / \mathrm{m}) \mathrm{l})$ & $(1.44 c+1)_{2}$ & $5.90(1+0) 2$ & $6,260+02$ & $4.930+102$ & $4.836+112$ & $4.910+102$ \\
\hline $1.14(s$ & $(|3 y / m|)$ & $2.51(\cdot+1) .3$ & $2.57 c+0.3$ & $2.93:+0.3$ & $2.0150+0.3$ & $2.0 .3 x+0.3$ & $1.9610+10.3$ \\
\hline $1 \%$ is & $(\mathrm{BC} / \mathrm{mll})$ & $2210+115$ & $2.220+0.5$ & $2.16 x+115$ & $1.86 x+1.5$ & $1.870+0.5$ & $1,910+0.05$ \\
\hline $151: 4$ & $(|B(y / m)|)$ & $-1.60+02$ & $<2.16+12$ & $<2.7 c+12$ & $<1.7 a+02$ & $<2.20+112$ & $<2.10+1)^{2}$ \\
\hline $15 / 1 \cdot 11$ & $(\mid 3(p / m \mid)$ & $81.50+102$ & $<1.6 x+1)^{2}$ & $<1,20+12$ & $<1.50+112)$ & $<1.1 \mathrm{c}+112$ & $<1.1 k+1) 2$ \\
\hline $1991: 4$ & $(B(\mathrm{~g} / \mathrm{m}) \mid)$ & $-7.20+12$ & $<7.10+102$ & $\therefore 7.2 c+102$ & $<0.70+102$ & $<0.60+02$ & $<11,(x+1)_{2}$ \\
\hline 11 & $(B(\mathrm{~g} / \mathrm{ml} \mathrm{l})$ & $20110+112$ & $2.010+102$ & $2.0110+(12$ & $2.114 \div 102$ & $2.016+(12$ & $20110+112$ \\
\hline Nh & $(B(p / m) l)$, & $(1,4 c+101$ & $(0.2(0+1) 1$ & $<0.30+02$ & $<s \mid c+1) \mid$ & $<5.50+011$ & $<s .8(+0)$ \\
\hline $\operatorname{lix}|k|$ & $(\mid 3(y / m))$, & $-210+03$ & $\int 2 .(1)+103$ & $<2,0 c+03$ & $-1 . \%+03$ & $<1.40+13$ & $<1.90+103$ \\
\hline 'Sir & $(\mid s y / m u l)$. & $7.1 .30+103$ & $7.01 x+0.3$ & $7.110+0.3$ & 0.750 .1613 & $0.700 .+10.3$ & $0.700+10.3$ \\
\hline "il & $(|3 y /| m 1)$ & $\therefore(1) 3 c+11)$ & $41.10+102$ & $<1 .(k+1) !$ & $<1) .5 c+611$ & $<1.10+12$ & $(1) .30+1) 1$ \\
\hline
\end{tabular}


l'able 4.2.3. Uniformlly of waslo lank supormale

\begin{tabular}{|c|c|c|c|c|c|c|}
\hline Stumple" & $\mathrm{pH}$ & $\begin{array}{c}{ }^{(t)} \mathrm{Co} \\
(\mathrm{BC} / \mathrm{m} / \mathrm{I}) .)\end{array}$ & $\begin{array}{c}134 \mathrm{Cy} \\
(\mathrm{Bc} / \mathrm{m} / .)\end{array}$ & $\begin{array}{c}1.1 \% \mathrm{Cs}^{\mathrm{s}} \\
(13 \mathrm{~g} / \mathrm{mul})\end{array}$ & $\underset{(m y / l .)}{C r}$ & $\begin{array}{c}U \\
(m, g / l .)\end{array}$ \\
\hline$W 21 \cdot 1,1$ & & 8640 & 5240 & $3.240+0.5$ & 2.5 .0 & 6)(1) \\
\hline$W 2\{\ldots 1.2$ & 0.56 & 8620 & 5220 & $3.210+0.5$ & 27.0 & 7.50 \\
\hline W21.1.3 & & 8390 & 4920 & $3.10 c+0.5$ & 24.0 & 710 \\
\hline W24-1 1 & & $<300$ & 125() & $2.22 c+0.5$ & 3.3 & 10.3 \\
\hline W24.1.2 & 13.1 & 400 & 1130 & $2.24 c+0.5$ & 3.1 & 9.4 \\
\hline W24.13 & & 338 & 14.50 & $2.28 c+0.5$ & 3.5 & 10.5 \\
\hline W2S.1.1 & & 1670 & 3440 & $3.32 \mathrm{e}+0.5$ & 2.0 & $<(1), 1$ \\
\hline W25-1.2 & 12.5 & 1840 & $36(x)$ & $3.26 x+0.5$ & 1.9 & $<(), 1$ \\
\hline W2.5-1.3 & & 1710 & 3790 & $3.43 c+0.5$ & 2.0 & $<(1) .1$ \\
\hline$W 2(1.1 .1$ & & 14300 & $121(1)$ & $2.210+00$ & 1.8 & 912 \\
\hline$W 2(1.1 .2$ & 11.2 & $107(1)$ & $102(0)$ & $2.08 c+(10)$ & 1.8 & 11.30 \\
\hline$W 26.13$ & & $120(\%)$ & 11700 & $2.09 c+106$ & 1.7 & 808 \\
\hline W27-1.1 & & 346 & 1.560 & $2.26 c+0.5$ & 2.5 & $<0.1$ \\
\hline W27.1.2 & 11.8 & 253 & 1510 & $2.18 \mathrm{c}+0.5$ & 2.8 & $<(1) .1$ \\
\hline W27-1.3 & & $<.30(1)$ & 1400 & $2.26 x+1) 5$ & 2.6 & $<0.1$ \\
\hline W2S-1.1 & & 8730 & 10100 & $5.85 \mathrm{c}+0.5$ & 0,30 & 1.20 \\
\hline$W 28-1.2$ & 9.1 & 8640 & 10800 & $5.8 .5 \mathrm{e}+0.5$ & 0.38 & $<(1,1)$ \\
\hline W 28.1 .3 & & 8290 & 9550 & $5.84 c+0.5$ & 0,33 & $<(0.1$ \\
\hline$W / 3 \mid-1.1$ & & $<2(0)$ & 4.560 & $2.31 \mathrm{c}+(1.5$ & 5.4 & $(1,21)$ \\
\hline$W 31-1.2$ & 11.7 & $<200$ & 4580 & $2.23 c+0.5$ & 6.0 & 0.25 \\
\hline$W .3 \mid-1.3$ & & $<200$ & 4.590 & $2.33 c+(1.5$ & 5.6 & 0.30 \\
\hline
\end{tabular}

"Simple identificalion code: $-1.1=1 / 3$ supernalant level; $-1.2=1 / 2$ supernatant level, $-1.3=2 / 3$ supernallant level. 


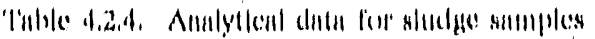

\begin{tabular}{|c|c|c|c|c|c|c|}
\hline \multicolumn{2}{|c|}{ ('lintrieteristlo' } & Wals & Wat.S & $W_{2} d-S$ & W2,5.S & Wa.t.S \\
\hline \multicolumn{7}{|c|}{ 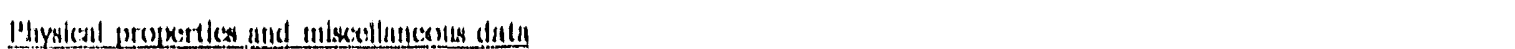 } \\
\hline TS & $(111 / \mathrm{g} / \mathrm{y})$ & $\$ 11$ & $.54 d$ & $48 \%$ & .5 .11 & 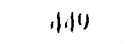 \\
\hline Demitly & $(4 / \mid I I))$, & 1.411 & $1,3.4$ & 1,211 & 1.12 & 1.51 \\
\hline 11 & (III!/ki!) & $12(K n)$ & $|8| 100$ & $0(1.30$ & 3920 & $12(1) 10$ \\
\hline ' $T C^{\prime}$ & $(\mathrm{min} / \mathrm{k} / \mathrm{s})$ & $\mid 8 s(x)$ & $222(x)$ & $0.5 \%$ & 1250 & 182010 \\
\hline$I^{\prime}(x)$ & $(1114 / k+1)$ & $(6480$ & 1120 & $2(14010$ & 2330 & 62210 \\
\hline \multicolumn{7}{|c|}{ RCCRA moluls } \\
\hline At & $(I 11) / k !)$ & $(5(1)$ & $(2 K)$ & $(<7.7)$ & $(\lessdot \%, 6)$ & (111) \\
\hline$\Delta u$ & $(\mathrm{ml} / \mathrm{k} / \mathrm{f})$ & (42) & $(<.5(1)$ & $\therefore \sqrt{2}$ & $<11$ & 1,5 \\
\hline$\left|H_{i}\right|$ & $($ IIIt/kiti) & 78 & 0.3 & 4 & 59 & 3\% \\
\hline ( 'd & (millikg) & 27 & 32 & 0.1 & 11 & 4. \\
\hline ('r & $(m g / k g)$ & l(it) & $1(x)$ & 31 & 59 & $1 \%$ \\
\hline $11 \%$ & $(1111 / k / k)$ & 50 & 19 & $\therefore$ & .37 & 0.1 \\
\hline $\mathrm{Ni}$ & $($ IIIIg/kg) & 75 & 110 & 22 & 31. & $1 !$ \\
\hline Ih & $($ III)/kis) & $2(1)$ & $(4,50)$ & 1.50 & 220 & $4 \%$ \\
\hline sii & (III)/ $/ \mathrm{ig}$ ) & $<a s$ & $\div 31$ & $<52$ & $<51$ & $\varsigma 5 s$ \\
\hline 11 & $(m i / k n)$ & $<11$ & 516 & $<16$ & $<16$ & $\because 17$ \\
\hline \multicolumn{7}{|c|}{ Proxcesy molnls } \\
\hline $\mathrm{AI}$ & (min/kj!) & $\log (0)$ & $2 x(k)$ & 1000 & $2 R(x)$ & 7.5010 \\
\hline 11 & (III)/ $/ k$ i) & $<0,1)$ & $<.10$ & 3.1 & $<1.5$ & 47.1 \\
\hline ( 'ia & (Ing/kif) & $1,5(x)$ & $5.5(x)$ & $2(1)(1)$ & $38(1)(x)$ & $3(1)(1) 10$ \\
\hline$(\because$ & (III)/ $/ k$ is) & & - & $<1.3$ & .1 .3 & . \\
\hline lin & $(111 \mathrm{~g} / \mathrm{k}) \mathrm{g})$ & $23(x)$ & $19(x)$ & $8(1)$ & 9411 & 231110 \\
\hline$k$ & $(m i k k f)$ & $8.5(10)$ & $18(8) 0$ & $7(),(x)$ & 1200 & 1.501110 \\
\hline$M g$ & (III)/ $/ k$ !) & $y(x)$ & $10(1)(0)$ & $5(1)(1)$ & $59(1)$ & $110110)$ \\
\hline $\mathrm{Ni}$ & (miflig) & $\ln x(x, n)$ & $82(x)(1)$ & $(1)(0)(1)$ & $0(0)(1)(1)$ & 5101010 \\
\hline sir & (ing/kg) & $2(1)$ & $2 \%$ & 1111 & 1,50 & 120 \\
\hline $1 \%$ & $(\mathrm{~m}) / \mathrm{kg})$ & $1.37(x)$ & $120(k)$ & 1480 & .386010 & ")\}(1) \\
\hline 11 & (III)/kis) & $31(4)()$ & $17(x)$ & $37(1)$ & 4800 & 21100 \\
\hline
\end{tabular}

Belin/pamman comilters

coross alphat (Bo/th)

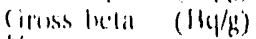

${ }_{1.1}(\mathrm{~B})$

ith (ce) (IH/g/g)

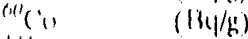

$1.1 \%(s) \quad(13 / / g)$

$1.1)^{\prime}(s) \quad(13 \mathrm{y} / \mathrm{g})$

$15 \% 11 \quad(13 / 2 / 4)$

$1.11: 11 \quad(134 / 4)$

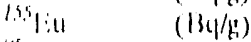

$1.5 \mathrm{Nh} \quad\left(13 \mathrm{~g} / \mathrm{tg}^{\mathrm{i}}\right)$

lixilin $\quad(B / y / g)$

(x) $\mathrm{sic}$ (Buyge)

$(B / 4 / 5)$

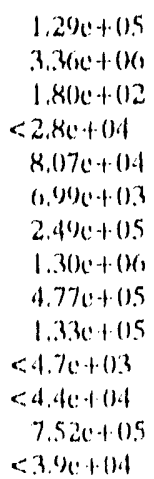

Applun comitlers

\begin{tabular}{|c|c|}
\hline 4 & $(\mathrm{By} / \mathrm{H}$ \\
\hline $2 \cdots 11$ & $(130 / 4$ \\
\hline (1) & $(\mathrm{BH} / \mathrm{g})$ \\
\hline 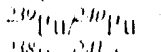 & $(k y) / g_{1}$ \\
\hline 政" & $(134 / 2)$ \\
\hline 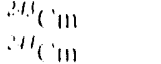 & $(B(y / k)$ \\
\hline & \\
\hline
\end{tabular}

$8.1 .30+10.3$

$2.80+04$

$2.490+1.1$

$5.136+0.4$

$42.50+11.4$

$4.46 x+10.4$

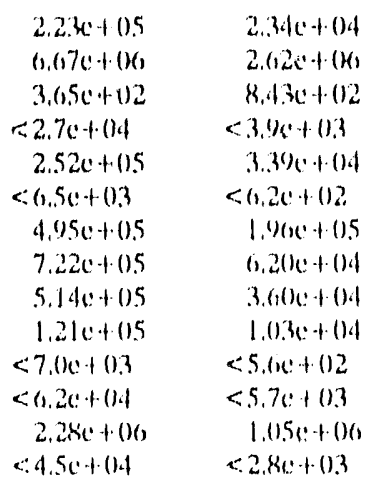
$4 .(1.50+0.04$
$4 .(6) c+0)(1)$
$1.710+0 \%$
$<4.20+1.3$
$4.1130+04$
$7.07 \mathrm{e}+102$
$2.210+105$
$8.140+10.1$
$5.06(x+1)$
$1.630+1.4$
$<5,90+02$
$<.5,13(1)+(1) 3$
$1.6 .56+106$
$<4.610+1.103$

$5.150+112$
$1.180+(04$

$<2.80+1.4$

$1.180+0.4$

$3.210+104$

$<2.60+(1) .4$

$1.17 \%+10.5$
$<3.70+0.3$

$1.54 c+0.8$

$3.7 .6+11.3$

$<3 .(x+0) 3$

$1.63(0+0) .1$
$8.3 \%+02$

$<4.20+0.3$

$2.9 .30+10.3$

$7.350+10.3$

$<3 \%+10.3$

3.120 .111 .4
$0.130+10.4$

$5.710+106$

$2.1 .30+(12)$

$-1.20+101$

$1.0 .30+0.5$

$2.970+(1) 3$

$6.640+105$

4. 920.105

$3.1 \%+105$

7.911 .111 .1

a. $2(10+1) .3$

c.5e+1).

$\therefore(1.3010101$

a...20.105

$$
\begin{aligned}
& 0.616 x+0.3 \\
& 61.20+10.1 \\
& 5.110 .10 .3 \\
& \text { 1. } \mid 18.101 \\
& 61.30+11.1
\end{aligned}
$$


'lable 4,2.4 (comllnumel)

\begin{tabular}{|c|c|c|c|c|c|c|}
\hline \multicolumn{2}{|c|}{ C'lunincloriallo } & $W 27.111 .4$ & $W 27.111 .11$ & WבH.S & W:II-S & W:11. \\
\hline \multicolumn{7}{|c|}{ 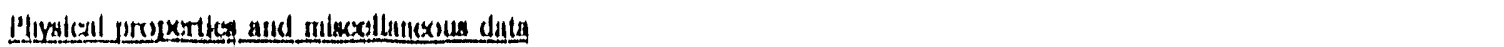 } \\
\hline T's & (IIIg/g) & 180 & $47 !$ & 5.3 .3 & 3019 & $y(14$ \\
\hline Densily & $(\mathrm{g} / \mathrm{mil})$ & 1,26 & $1,3.3$ & 1.40 & 1.20 & . \\
\hline IC: & $(m g / k g)$ & 5250 & 12700 & 360 & 1410 & 210100 \\
\hline 'I' & $(m g / k g)$ & $7(1, \mathcal{M})$ & 10.500 & 6120 & 1820 & $3(1) 1(16)$ \\
\hline ' & $(\mathrm{mg} / \mathrm{k} \mathrm{ig})$ & 2440 & 38.70 & $25(0)$ & 1110 & $85: 30$ \\
\hline \multicolumn{7}{|c|}{ RCRA motah } \\
\hline$\overline{\mathrm{Ag}}$ & $(111 \mathrm{~g} / \mathrm{kg})$ & $(<7,2)$ & $(<1,3)$, & $(17)$, & $(<0,1)$ & $(<.5 .4$ \\
\hline 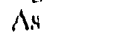 & $(m y / k g)$ & $<.39$ & $<09^{\circ}$ & 27 & $<3.3$ & $<29$ \\
\hline Min & (mg/kg) & 49 & 72 & .31) & 17 & $\mid 80$ \\
\hline (d) & $(m g / k g)$ & 1.3 & 17 & 26 & 1.7 & $1 . .5$ \\
\hline $\mathrm{Cr}$ & $(m g / k g)$ & 6.5 & $y)$ & $\$ 5$ & 27 & 7.5 \\
\hline $11 \lg$ & $(m g / k g)$ & 11 & 18 & 12 & 14 & 39 \\
\hline $\mathrm{NI}$ & $(m g / k g)$ & 27 & 40 & 62 & 19 & $\$ 2$ \\
\hline 保 & $(m g / k g)$ & 120 & $2(x)$ & $1 \%$ & 170 & $3(10)$ \\
\hline Se & $(m g / k g)$ & $<49$ & $<80$ & $<29$ & sill & $<37$ \\
\hline 'l' & $(m g / k g)$ & 20 & 427 & $\measuredangle !$ & $<13$ & $\because 11$ \\
\hline \multicolumn{7}{|c|}{ l'rocoxs metuls } \\
\hline$\Delta$ & $(m g / k g)$ & $43(0)$ & $68(0)$ & 830 & $1 / 1100$ & $\mid(1,0) 00$ \\
\hline 11 & (Ing/kg) & $<6,4$ & $<11$ & 4.9 & $<1.2$ & 22 \\
\hline ('il & $(m g / k g)$ & $38(2)(K)$ & $54(0) 0)$ & $57(0) 00$ & $56(1) 0$ & $63(100)$ \\
\hline$(\therefore$ & $(m g / k g)$ & & & $<(1), 8$ & $<1.1$ & 2.4 \\
\hline $\mathrm{ICO}$ & $(m g / k g)$ & $14(0)$ & $25(\%)$ & 0.30 & 420 & 77110 \\
\hline$k$ & $(111) / k g)$ & $6 !(x)$ & $6,7(0)$ & $1110(x)$ & $7(x) 0$ & $67110)$ \\
\hline MH & $(\mathrm{mg} / \mathrm{kg})$ & $.18(x)$ & $S y(x)$ & $1.50(0)$ & $8 \%$ & 3100 \\
\hline $\mathrm{Nil}$ & $(111 \mathrm{f} / \mathrm{kg})$ & $716(x)$ & $6(x)(x)$ & $\ln (x)(x) 00$ & $6 \%(x)$ & $48(0) 00$ \\
\hline Si & $(m g / k g)$ & $\mid 21$ & 1.50 & 130 & 30 & 170 \\
\hline l'h & (ing/kt) & 1890 & $3(1.40$ & 1.170 & 2790 & 1180111 \\
\hline 11 & $(m g / k g)$ & 2710 & l\%(6) & $17(0)$ & $30(0)$ & 9210 \\
\hline
\end{tabular}

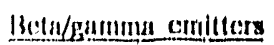

\begin{tabular}{|c|c|}
\hline המרון & $(1 \mathrm{H} / \mathrm{g})$ \\
\hline (15s) hetar & $(\mathrm{Bc} / \mathrm{h}$ \\
\hline & $(\mathrm{Bg} / \mathrm{gg}$ \\
\hline$(\because$ & $(\mathrm{Bc} / \mathrm{s}$ \\
\hline & $(\mathrm{B} / \mathrm{c} / \mathrm{g}$ \\
\hline lin & $(\mathrm{Bg} / \mathrm{g}$ \\
\hline 1.11 ( & $(B \mathrm{c} / \mathrm{s} / \mathrm{s}$ \\
\hline 154$\}$ & $\left(B y_{1} / g\right.$ \\
\hline $154 \mid 1 \leq 11$ & $(B \mathrm{~B}) / \mathrm{g}$ \\
\hline $155[\div 11$ & $(\mathrm{Bc}) / \mathrm{g}$ \\
\hline${ }^{15} \mathrm{Nh}$ & $(B \mathrm{C} / \mathrm{g}$ \\
\hline सर। & $(B \mathrm{G} / \mathrm{g}$ \\
\hline & $(B \mathrm{~B})$ \\
\hline & \\
\hline
\end{tabular}

\begin{tabular}{|c|c|c|}
\hline $2.290+104$ & $3.10 k+104$ & $5.30 \mathrm{e}+(0,4$ \\
\hline $1.44 c+(x)$ & $2.1120+060$ & $2.40 \mathrm{c} \cdot 100$ \\
\hline $1.890+12$ & $4.88 x+102$ & $7.616(k+0)$ \\
\hline$<5 .(x)+10.3$ & $<7 . \%+0.3$ & $<1,70+04$ \\
\hline $1,(110+0+1) 4$ & $2.50 x+04$ & $7.910+(1)$ \\
\hline$<1.20+0.3$ & $<1,84+0,1$ & $<4,6 c+0,3$ \\
\hline $3.75 c+10.5$ & $5.71 \mathrm{e}+105$ & $1.94 c+0.5$ \\
\hline $1.9 \%+104$ & $2.42 c+04$ & $7.180+0.5$ \\
\hline $1.260+04$ & $1.510+014$ & $3.2(1)+0.5$ \\
\hline$<3,4 c+0.3$ & $3.26 x+0.3$ & $9.700+0.0$ \\
\hline$<7,3 \mathrm{c}+(1) 2$ & $<1,4 \mathrm{e}+0.3$ & $\therefore 2,90+(1,3$ \\
\hline$<1.10+0.4$ & $<1,(x+2) 4$ & $<2.8 c+1.4$ \\
\hline $4.550+0.5$ & $5.510+0.5$ & $5.57 c+0$ \\
\hline & & \\
\hline
\end{tabular}

\begin{tabular}{|c|c|}
\hline $2.310+(1) 4$ & $8,450+10.1$ \\
\hline $3,180+1161$ & $1.1010+107$ \\
\hline $3.146+12$ & $1.050 \cdot 10.4$ \\
\hline$<0,40+0,3$ & $\therefore 1.910+10.1$ \\
\hline $8.10 c+0.3$ & $3,010 .+10.1$ \\
\hline $3,64 c+10,3$ & $2.07)+(1.3$ \\
\hline $2.350+11.5$ & $5.520+0.5$ \\
\hline$<1.70+04$ & $2.720+0.1$ \\
\hline $5,460+0.3$ & $2.070+10.4$ \\
\hline$<5 . \%+0.3$ & $<8.70+0.3$ \\
\hline$<0.2 c+112$ & $<1.20+18\}$. \\
\hline$<1,4 v+6,4$ & $<1.70+(0.1$ \\
\hline $1.420+1) 6$ & $5.1 \%+616$ \\
\hline$<4.7 c+0.1$ & $<6,(x)+18)$ \\
\hline
\end{tabular}

Alphen emitters

\begin{tabular}{|c|c|}
\hline 711 & $(B, / g / g)$ \\
\hline 2111 & $(\mathrm{Bg} / \mathrm{g})$ \\
\hline .11 & $(13 \mathrm{G} / \mathrm{g})$ \\
\hline$\therefore p u r \cdot n$ & ( $(B \mathrm{~g} / g)$ \\
\hline 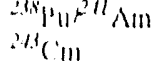 & $\begin{array}{l}(B \mathrm{Bg} / \mathrm{g}) \\
(\mathrm{Bg} / \mathrm{g})\end{array}$ \\
\hline$\therefore 4$ & $(\mathrm{BC} / \mathrm{g})$ \\
\hline
\end{tabular}

$5.180+02$

$<.5,8 c+0.3$

$1.04 \mathrm{c}+0.3$

$4.410+(1.3$

$<0.50+0.3$

$1 .(0) c+104$
$0.21 k+102$

$<8,3 x+0.3$

$1.86 x+103$

$0.73 c+0.3$

$<1,1 \mathrm{k}+0 \mathrm{04}$

$2.150+0.1$
$1.460+10.3$

$3.5(x)+103$

$<1.70+(04$

$1.510+00$

$5.28 \mathrm{c}+0.3$

$<1,4 c+(1) 4$

$3,8,2:+104$
$5.080+102$

$<0.70+0.3$

$8.786+12$

$2.4 .3 c+11.3$

$<8.40+0.3$

$1.710+1.1$
$2.050+11.3$

$<1.40+1114$

$3.22 \cdot 10.3$

$1.120+10.1$

$<1.30+10.1$

(.).8. 110.1 


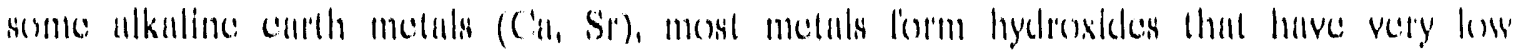

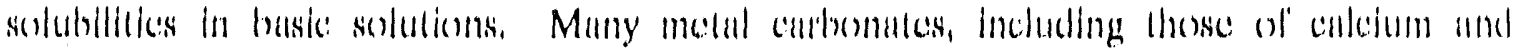

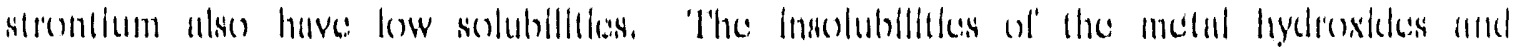

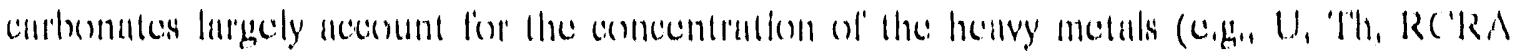

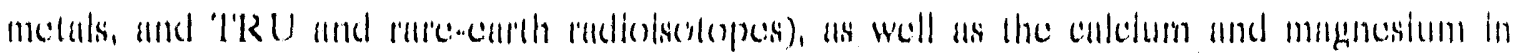

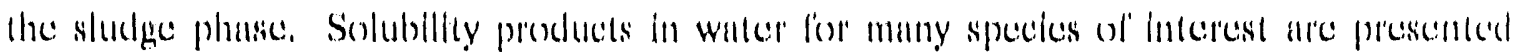

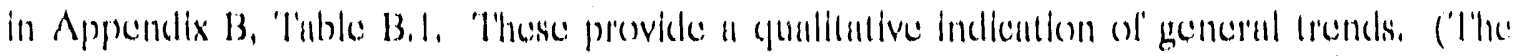

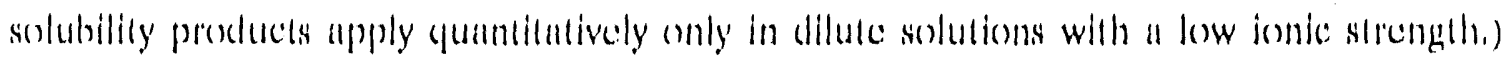

\subsubsection{Inorganic and Physical Charactcristics of Liquid Sumplos}

\subsection{3,1 Major Inorganic Compononts in Licjuid Samples}

The supermalant lieguid waskes in thin storage lanks, execpol lank W-21, are essisentially

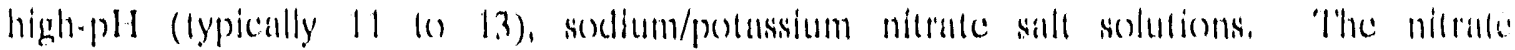

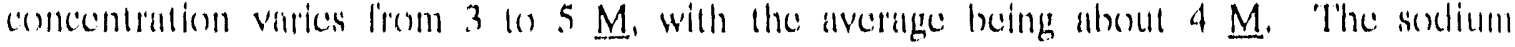

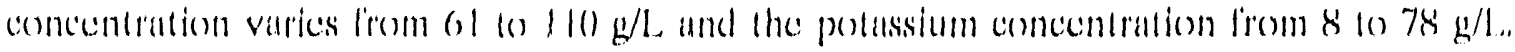
The potassium levels are higher in the more recently generaled LLW evaporater concentrates than in the older waskes, The $\mathrm{K} / \mathrm{N}$ a mass ration: are 0.8 and 1.0 for the supernales in tanks W.20 and W-23, respectively, comprared wilh 0.1 10 0.3 in the onhere

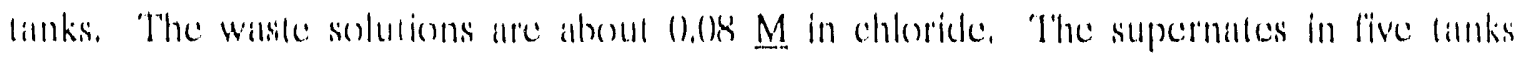

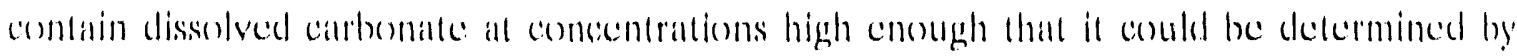
perencionmetric: ditrations.

The supernale in lank W-21 (lhe PW'P evalperallor conteh tank) was found lo be

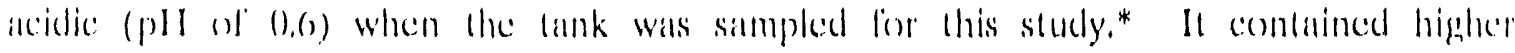
concentrations of conkium, magnesium, and heavy medals than did the basic waste solulions. (arbonale and hicarbenale: ions ane not stable in acedic solutions; they react with hydronium ionsi lo lorm ('O), (gisis) and water.

I'he concembations of the major inorganic: constiluents in grequivalents/l. (N) arte given in table 4.2.:. The callom-anion balance is good, considering that these are radionctive sampless with a high sull malrix.

* Afler the lanks were sampled for this study, 5,200) gal of waste wals transplerted

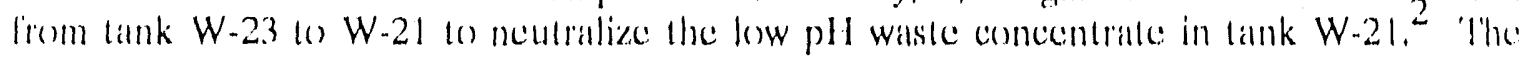
pll of the lieguid sample collected from lank W-21 in June 1990) was 6.9 (neulmal). 


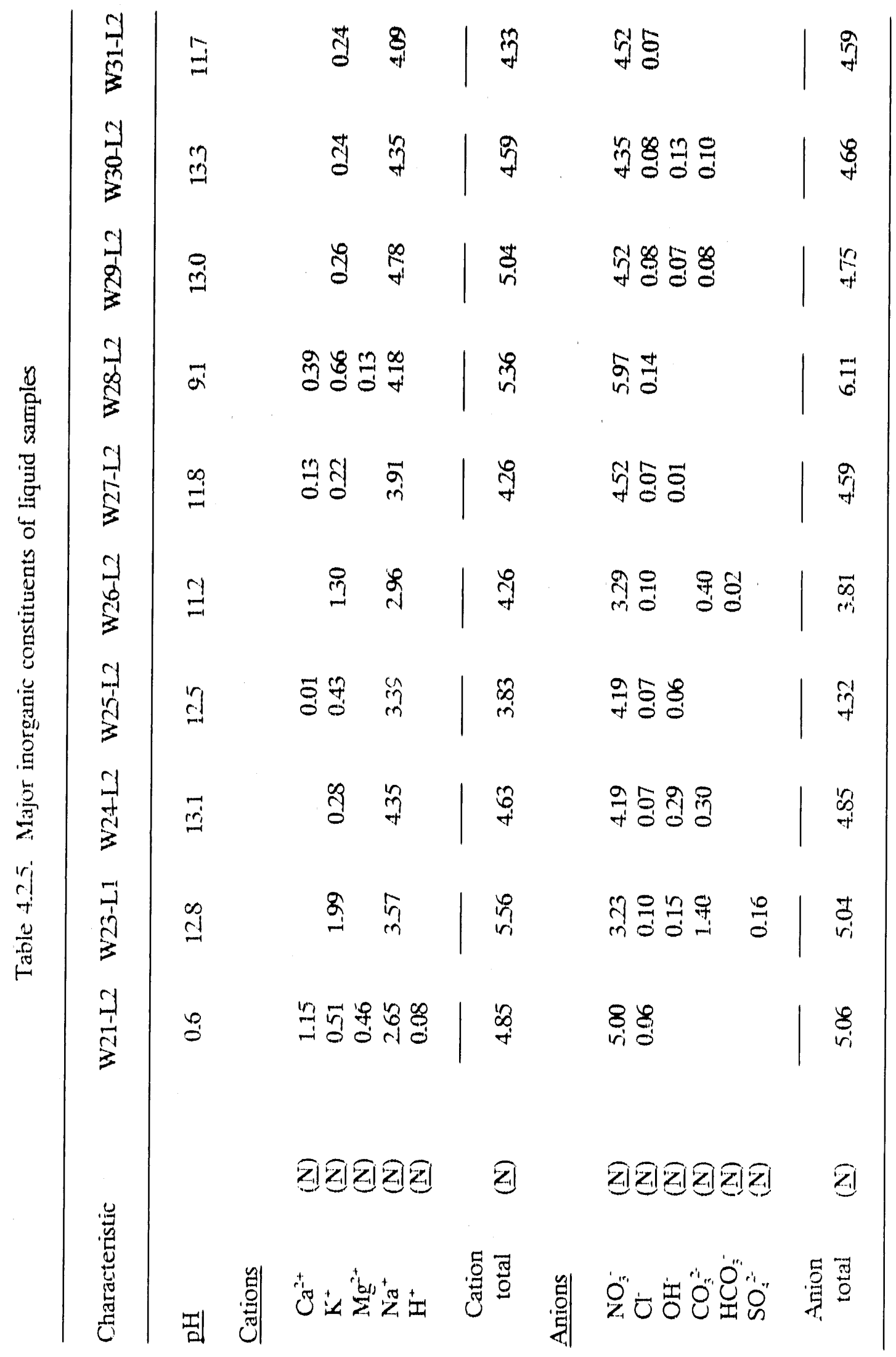




\subsubsection{Proxessy Motals in Liquid Sumpless}

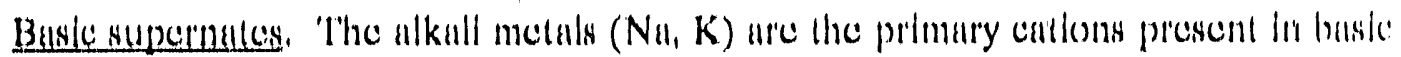

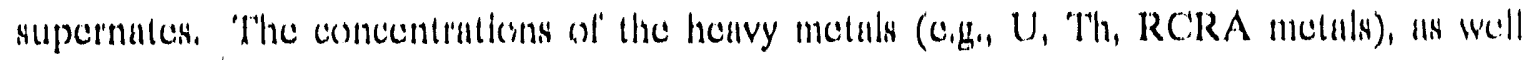
as the iron and aluminum, in such wastes are in the low.ppon range as would be expecied from the Insolubilitios of the hyclrexides and carbonales. The concentrations of calcium

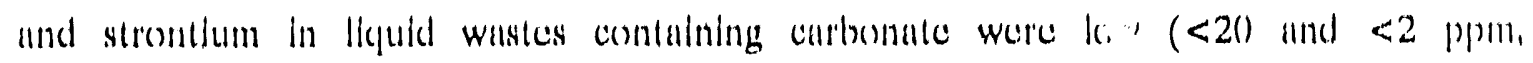
respectively), largely becinuse ol the limited solubility of CaCO, and SrCO, By comparlson,

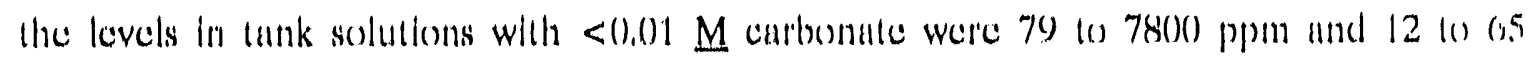
ppm, respectively, The pH of lank W-28 is a llate lower than that of the others, 'Ithe liguid waste in this tank contalns a higher level of magnesium than the other lanks $(100)$ ppm at a pH of 9 compared with <4 ppm al " pH of 11 lo 13), as would be expecied from the solubility of $\mathrm{Mg}(\mathrm{OH})_{2}$. At a higher pH, the common-lon efl'ect suppresses the ionization and, hence, the dlssolution of $\mathrm{Mg}(\mathrm{OH})_{2}$. Cobalt was not delected in the six lank samples that were analyeed (limit of detection, $0.57 \mathrm{mg} / \mathrm{L}$ ).

The uranium concentration in llac tank W-26 waste solution is higher (1130) pporn) than in the other basic tanks. This may be due to the formation of a uranyl dricarbonate complex $\left|\mathrm{UO}_{2}\left(\mathrm{CO}_{1}\right)_{3}{ }^{4}\right|$ that is stable in basic carbonate/bicarbonate solutions. ${ }^{3}$ The uranium can be precipitaled all a pH of about 12 or above. ${ }^{3}$

The boren and soluble silica concentrations in the licquid wastes were low (typleally $<4$ and $<12$ ppm, respectively). The soluble silica concentration was slightly higher in lank W-24 (i.c., $245 \mathrm{ppm})$.

Basic solutions ternd to disselve atmospheric carbon dioxide and accumulale increasing amounts of carbonate with time. The end result, then, may be the precipitation of carbonates from tank solutions that presently coratain dissolved calcium and strontium (including "Sr) and other shifts in the equilibrium state of the solutions related to pll changes.

Tank W-21. The supernate in lank W-21 was acidic (pH of 0.6 ) at the time the lank was sampled. This aqueous waste contained significantly higher levels of calcium, magnesium, and heavy metals than did waste in the other tanks and was not in equilibrium with the incerstitial liquid ( $p H$ of 7 ) in the sludge phase. 


\subsubsection{Anions in Liquid Samples}

The principal anions were nitrate ( 3 to $5 \underline{\mathrm{M}}$ ), carbonate (in some tanks), and chloride (0.06 to $0.14 \underline{\mathrm{M}})$. Sulfate was detected in tank W-23 (0.08 $\underline{\mathrm{M}})$. Fluoride and phosphate were not detected at the reporting limits, which were 0.026 to 0.053 and 0.053 $\underline{\mathrm{M}}$, respectively. The reporting limit for sulfate was $0.052 \underline{\mathrm{M}}$. As discussed in Appendix B, Sect. B.4.3, a new ion chromatograph is currently being installed for analyses of radioactive waste samples. Following some methods development work, more-detailed anion data should be obtainable for future waste tank samples.

\subsubsection{Inorganic and Total Organic Carbon in Liquid Samples}

Inorganic carbon (IC) in the liquid samples varied from low ppm to $8340 \mathrm{ppm}$. It can be accounted for by the carbonate in the solution. The ratio of inorganic carbon to carbonate carbon varied from 96 to $106 \%$. The total organic carbon (TOC) concentrations in the aqueous liquid wastes were typically 400 to $600 \mathrm{ppm}$, although the levels for tanks W-23 and W-26 were higher (1160 and $1280 \mathrm{ppm}$, respectively). The organic carbon characterization is discussed in Sect. 4.3 and Appendix D.

\subsubsection{Physical Measurements of Liquid Samples}

The total solids (TS) content, based on the weight of residue after drying a measured volume of sample overnight at $115^{\circ} \mathrm{C}$, ranged from 334 to $478 \mathrm{mg} / \mathrm{mL}$. The results for the total dissolved solids (TDS), where the sample was filtered before drying, are similar to the total solids measurements. The analyses for metals and other constituents were conducted on unfiltered samples. Good agreement was found between the mass of the cations and anions determined in the study and the total solids (accounted for 90 to $111 \%$ of the total solids).

The density measurements for the liquid wastes were typically in the range 1.21 to $1.24 \mathrm{~g} / \mathrm{mL}$. However, the density of one tank, W-28, was somewhat higher $(1.28 \mathrm{~g} / \mathrm{mL})$. These measurements corresponded with the dissolved solids contents of the samples.

\subsubsection{Uniformity of Supernate in Waste Tanks}

The aqueous samples from the one-third and two-thirds levels in the tanks (see Fig. 2.4.1) were screened to check the uniformity of the supernate. The supernate in the tanks appears to be uniform (see Table 4.2.3). 


\subsection{Inorganic and Physical Characteristics of the Sludges}

\subsubsection{Physical Measurements of the Sludges}

The total solids (TS) contents of the sludges, based on the weight of residue after drying a measured volume of sarnple overnight at $115^{\circ} \mathrm{C}$, were about 400 to $500 \mathrm{mg} / \mathrm{g}$, except for the hard sludge in tank W.31, which had a higher concentration (see Table 4.2.4). The sludges contain 50 to $60 \%$ water; however, this does not include any water of crystallization that might be associated with the precipitated solids.

The bulk density measurements of the wet sludges (i.e., the precipitated solids plus the interstitial liquid) were in the range 1.3 to $1.5 \mathrm{~g} / \mathrm{mL}$. These are the densities of the composite sludge samples that were used in both the chemical and the radiochemical analyses.

Results of physical properties tests (e.g., viscosity, sedimentation rate) on four of the sludge samples are described in a separate report by Ceo and Shor. ${ }^{1}$

\subsubsection{Process Metals in the Sludges}

The principal metals found in the sludges were sodium, potassium, calcium, magnesium, uranium, and thorium. Based on the total metals determined, the sodium and potassium combined are typically 40 to $60 \mathrm{wt} \%$; the calcium plus magnesium, 30 to $40 \%$; and the uranium plus thorium, 4 to $20 \%$. The uranium plus thorium account for $28 \%$ of the metals determined in tank W-21 sludges. The more recently generated soft sludges (W-21, W-23, and W-26) have higher uranium-plus-thorium concentrations than do the older wastes. Most alkali metals are soluble. While a small amount of sodium may be present in the sludge solids (e.g., $\mathrm{Na}_{2} \mathrm{U}_{2} \mathrm{O}_{7}$ may be precipitated), it is expected, based on solubility, that most of the sodium and potassium are present as dissolved salts in the interstitial sludge liquid. Most of the other metals are probably precipitated to the sludge solids, based on their low solubilities in the tank liquids (Sect. 4.2.2). The sludges also contain low levels of aluminum $(0.1$ to $0.8 \%)$ and iron $(0.1$ to $0.25 \%)$. The levels are higher in the hard sludge in the bottom of tank W-31. The boron concentrations in the sludges were very low $(<11 \mathrm{ppm}) .^{*}$ The sludges were not analyzed for silica.

*The boron data for the sludges in the report by Peretz gil al. ${ }^{4}$ have no meaning because a lithium borate fusion was used to dissolve the samples. 


\subsubsection{Inorganic Carbon and Total Organic Carbon in the Sludges}

The sludges typically contain 0.4 to 2 wt \% inorganic carbon (IC), as carbonatc. On a mole basis, this amounts to 0.3 to $1.8 \mathrm{~mol}$ of carbonate per kilogram. The inorganic: carbon concentration was lower in the tank W-31 soft (watery) sludge, which has a high sodium content but a relatively low calcium content. The total organic carbon (TOC) was typically in the range 0.2 to $0.6 \mathrm{wt} \%(0.8 \%$ in W-31). The organic carbon characterization is discussed in Sect. 4.3 and Appendix D.

\subsubsection{Anions}

The determination of anions within the sludge phase has been a problem. Ion chromatography may not be appropriate for anion determination in sludge samples since the solid phase must first be dissolved with a strong acid. The use of a sirong acid places severe limitations on the anions that can be determined by ion chromatography. Therefore, considerable development work may be required to obtain useful anion data for the sludge phase of the waste tanks.

Tests are being planned to wash a few sludge samples with water (to remove the interstitial liquid) and with dilute acid. The new ion chromatograph which is currenlly being installed for analyses of radioactive samples, could be used to examine the leachate.

\subsubsection{Radioactive Materials}

\subsubsection{Alpha Emitters (TRU Waste)}

Wastes that are contaminated with transuranium (TRU) alpha emitters with halflives greater than 20 years and activities greater than $3700 \mathrm{~Bq} / \mathrm{g}(100 \mathrm{nCi} / \mathrm{g})$ at the time of assay are classified as ":RU wastes. ${ }^{6}$ All of the composite sludge samples except the soll sludge in tank W-31 exceeded the $3700 \mathrm{~Bq} / \mathrm{g}$ threshold and, therefore, were identified as TRU wastes (see Table 4.2.6). If the tank W-31 sludge were dried, the solid residuc would then also be classifed as a TRU waste. The ${ }^{244} \mathrm{Cm}$ isotope has a half-life of 18 years and is excluded from the TRU-waste definition. However, it is included in Table 4.2 .6 beciase of its high specific activity in the wastes. The ${ }^{244} \mathrm{Cm}$ and TRU-waste isotopes contribute, on the average, 72 and $20 \%$, respectively, of the gross alpha in the sludge (excluding tank W-21); the uranium isotopes contribute only a few perent. The TRU-waste alpha in lank W-21 sludge was considerably higher than in the other sludges. Also included in Talble 4.2.6 are the checks on the alpha balance obtained by a ratio of the sum of the alpha 


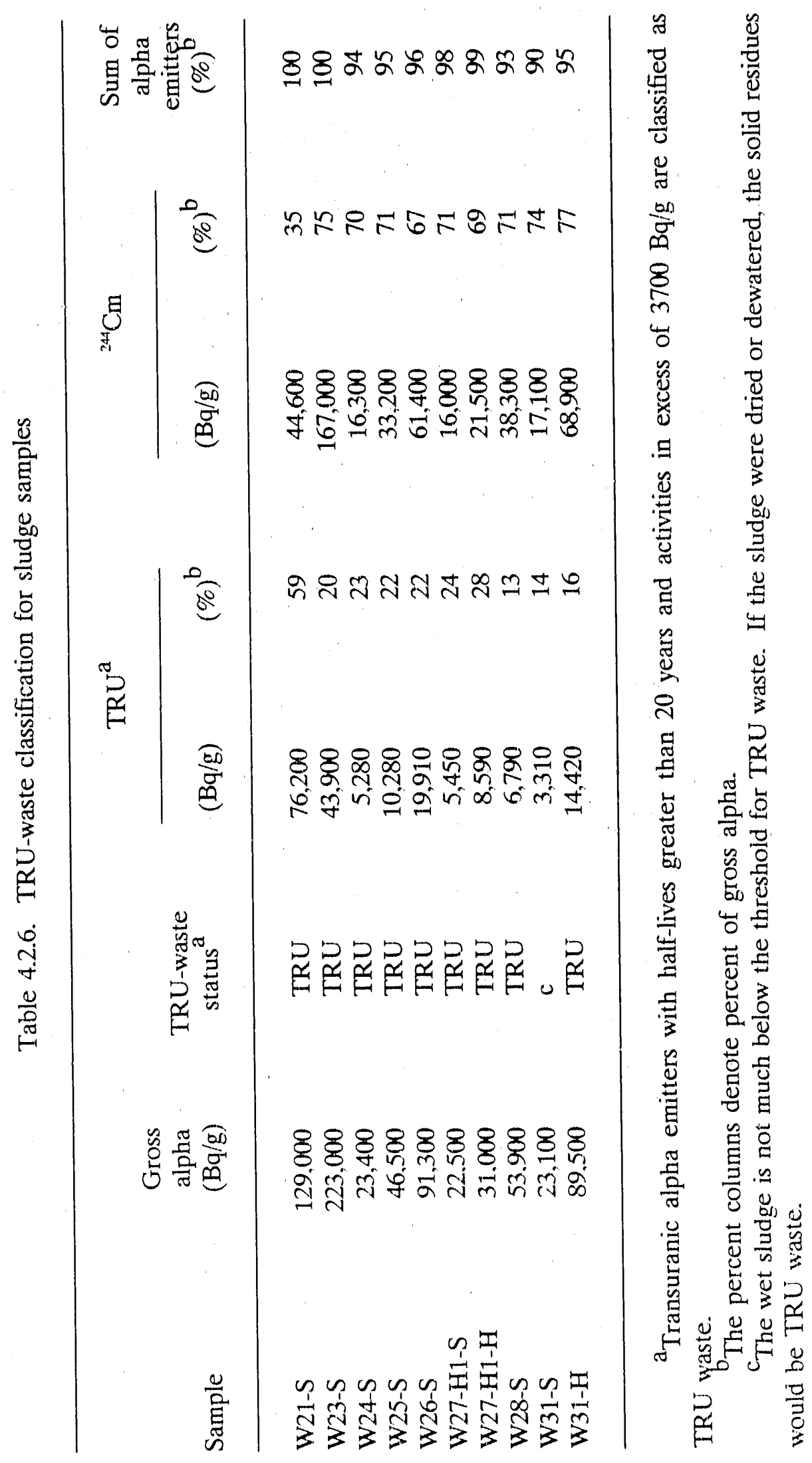


emitters identilied by alpha spectroscopy to the gross alpha. The alpha balance varied from 90 to $100 \%$ (average, $96 \%$ ).

In general, little or no alpha activity was observed in the basic liquid phases in the tanks (see Tables 4.2.1 and 4.2.2). Low levels of alpha activity were observed in the liquid samples from tanks W-21 and W-26. Tank W-21 supernate was acidic when the tank wals sampled for this study. Ninety-six percent of the gross alpha in the tank W-26 liquid can be accounted for as uranium isotopes. This is consistent with the above-average uranium metal content determined by fluorometric analysis (Sect. 4.2.3.2). The liquid samples were all non-TRU solutions; their salt residues, if dried at $115^{\circ} \mathrm{C}$, would also be non-TRU. Individual alpha emitters were determined if the results of the gross alpha analysis were high enough that meaningful results could be obtained by pulse-height analysis. If the gross alpha content was low, individual alpha emitters were not determined.

\subsubsection{Beta-Gamma Ernitters}

The most abundant radionuclides observed in the sludges were ${ }^{137} \mathrm{Cs}$ and ${ }^{n} \mathrm{Sr}$ and their short-lived daughters ${ }^{137} \mathrm{Ba}$ and ${ }^{90} \mathrm{Y}$, respectively. Most of the bela activity in tank solutions containing carbonate resulted from ${ }^{13.7} \mathrm{Cs}$, which was higher than ${ }^{\text {"x }} \mathrm{Sr}$ and other beta emitters by a factor of $\geq 30$. The ${ }^{90} \mathrm{Sr}$ was more soluble in supernates containing little or no carbonate and, together with its ${ }^{90} \mathrm{Y}$ daughter, contributed approximately one-third of the beta activity in those solutions. Gamma-active curopium isotopes were observed in the sludges. They were not detected in the liquid phase of any of the tanks that were basic bul were present in the acidic supernate in tank W-21. This observation is not surprising, considering the low solubility of europium hydroxide (sec Appendix B, Table B.1). Because of the age of the waste, ${ }^{95} \mathrm{Zr},{ }^{95} \mathrm{Nb}$, and ${ }^{144} \mathrm{Ce}$ (half-lives of 64,35 , and $284 \mathrm{~d}$, respectively) were not expected to be present. "Less-than" values for these radionuclides are included in the Tables 4.2.1, 4.2.2, and 4.2.4 for completeness.

Little tritium was found in the liquid samples; the ${ }^{14} \mathrm{C}$ concentration was also low in both the liquid and the sludge phases.

The gross beta balanees were obtained by ratioing the sum of the individual beta emitters, including the ${ }^{90} \mathrm{Y}$ daughter of ${ }^{9} \mathrm{Sr}$, to the gross beta determination. For liquid samples, the gross beta balances varied from 95 to $115 \%$ (average, 101\%) and the sludge samples from 86 to $109 \%$ (average, $98 \%$ ). 


\subsubsection{Nuclear Matcrials}

Estimates were made of the concentrations of nuclear materials in the wastes based on the radiochemical analyses (Table 4.2.7). It should be noted that the values given here are less than values and do not signify that these quantitics are present in the wastes. The

${ }^{239} \mathrm{U}$ and ${ }^{243} \mathrm{Cm}$ concentrations are based on the limit of detection by gamma spectroscopy. The ${ }^{219} \mathrm{Pu}$ and ${ }^{241} \mathrm{Am}$ were calculated by assuming that all the ${ }^{231} \mathrm{Pu} /{ }^{240} \mathrm{Pu}$ was ${ }^{216} \mathrm{Pu}$ and all the ${ }^{218} \mathrm{Pu} /{ }^{241} \mathrm{Am}$ was ${ }^{241} \mathrm{Am}$. The ${ }^{241} \mathrm{Pu}$ cannot be determined accurately by radiochemical analysis; mass spectroscopic analysis is required for quantitative determination. The ratio of the nuclear material to the total uranium, was $<2$ wt \% for wastes containing $480(0)$ to $31,000) \mathrm{ppm}(0.5$ to $3 \%)$ uranium.

\subsubsection{RCRA Evaluation for Inorganic Species}

A waste tank is classified as hazardous if the contents exhibit any of the following characteristics: (1) ignitability, (2) reactivity, (3) corrosivity, or (4) toxicity, according 10 specified procedures. Preliminary screening tests for RCRA characteristics, principally the hazardous metals, were included in the analysis plan. The RCRA metal limits and results of the sereening tests are presented in Tables 4.2 .8 and 4.2 .9 , respectively.

The waste tanks contain only aqueous-liquid phases. None of the tanks contained a RCRA ignitable waste. The liquid wastes in six tanks were corrosive with a $\mathrm{pH} \leq 2$ (W-21) or $\geq 12.5$ (W-23, W-24, W-25, W-29, and W-30). (The waste in tank W.21 has been neutralized since the tank was sampled for this study. ${ }^{2}$ )

The liquid phases in four of the basic tanks (W-23, W-24, W-26, and W-31) conlain one toxic metal each at a concentration that is high enough to classify the waste as RCRA hazardous (Table 4.2.9). The levels are in the low-ppm range and are only slightly above the threshold that defines a waste as RCRA. The supernatant liquid in tank W-21 wils acidic and contained higher levels of dissolved heavy metals than the other tanks. It exhitited the characteristic of "Extraction Procedure (EP) - toxicity" with respect to cadmium, chromium, lead, and mercury. Arsenic, selenium, thallium (a proposed RCRA metal), and silver (exeept tank W-26) were not detected at quantitative levels in the basic waste tank liquids.

The classification of the sludges is preliminary. The measurements listed are the total metal contents obtained with a nitric acid leach and are not the EP-toxicity or Toxicity 
Table 4.2.7 Estimates of nuclear materials in the sludges based on radiochemical analyses ${ }^{a}$

\begin{tabular}{|c|c|c|c|c|c|c|c|}
\hline \multirow[b]{2}{*}{ Sample } & \multicolumn{6}{|c|}{ Concentrations in waste $(\mathrm{mg} / \mathrm{kg})$} & \multirow{2}{*}{ 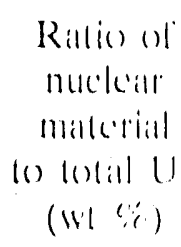 } \\
\hline & ${ }^{213} \mathrm{U}$ & ${ }^{215} \mathrm{U}$ & ${ }^{219} \mathrm{Pu}{ }^{\mathrm{b}}$ & ${ }^{241} \mathrm{Am}^{\mathrm{C}}$ & ${ }^{243} \mathrm{Cm}$ & Tolal U & \\
\hline W21-S & 23.1 & $<350$ & $<22.6$ & $<0.44$ & $<0.013$ & $31,(0)()$ & $<1.2$ \\
\hline W23-S & 33.5 & $<350$ & $<14.2$ & $<0.27$ & $<0.014$ & $17,(0) 00$ & $<2.1$ \\
\hline W24-S & 1.5 & $<46$ & $<0.7$ & $<0.03$ & $<0.0(12$ & $3,7(0)$ & $<1.2$ \\
\hline W25-S & 2.4 & $<53$ & $<1.3$ & $<0.06$ & $<0.0012$ & 4,800 & $<1.1$ \\
\hline W26.S & 18.9 & $<150$ & $<2.2$ & $<0.13$ & $<0.0(0) 7$ & 24,100 & $<0.6$ \\
\hline W27-H1-S & 1.5 & $<73$ & $<0.5$ & $<0.04$ & $<0.0013$ & 2,710 & $<2.7$ \\
\hline W27-H1-H & 1.8 & $<100$ & $<0.8$ & $<0.06$ & $<0.005$ & 1,960 & $<.5 .1$ \\
\hline W28-S & 10.1 & $<210$ & $<0.7$ & $<0.04$ & $<0.0017$ & $17,0(0)$ & $<1.2$ \\
\hline W31-S & 1.4 & $<120$ & $<0.4$ & $<0.02$ & $<0.004$ & 3,000 & $<4.1)$ \\
\hline W31-H & 5.8 & $<180$ & $<1.4$ & $<0.10$ & $<0.007$ & 9,200 & $<2 .(1)$ \\
\hline
\end{tabular}

${ }^{24} 1 \mathrm{Pu}$ cannot be determined accurately by radiochemical analysis; mass spectrosicopic analysis is required for quantitation.

${ }^{6}$ Calculated by assuming that ${ }^{239} \mathrm{Pu} /{ }^{210} \mathrm{Pu}$ is all ${ }^{230} \mathrm{Pu}$.

${ }^{c}$ Calculated by assuming that ${ }^{218} \mathrm{Pu} /{ }^{241} \mathrm{Am}$ is all ${ }^{241} \mathrm{Am}$. 
Table 4.2.8, Regulatory limits for RCRA metals in solid waste

\begin{tabular}{|c|c|c|}
\hline Element & $\begin{array}{c}\text { (Liquid) } \\
\text { Regulatory limit } \\
(\mathrm{mg} / \mathrm{L})\end{array}$ & $\begin{array}{c}\text { (Sludge }) \\
\text { EP-toxicily equivalent } \\
(\mathrm{mg} / \mathrm{kg})\end{array}$ \\
\hline As & 5.0 & 100 \\
\hline $\mathrm{Ba}$ & $1(x)$ & $20(0)$ \\
\hline $\mathrm{Cd}$ & 1.0 & 20 \\
\hline $\mathrm{Cr}$ & 5.0 & 100 \\
\hline $\mathrm{Pb}$ & 5.0 & 100 \\
\hline $\mathrm{Hg}$ & 0.2 & 4 \\
\hline $\mathrm{Se}$ & 1.0 & 20 \\
\hline $\mathrm{Ag}$ & 5.0 & 10() \\
\hline $\mathrm{Ni}$ (proposed) & 50 & $10(0)$ \\
\hline T1 (proposed) & 0.9 & 18 \\
\hline $\mathrm{pH}^{-\cdots}$ & $\leq 2$ or $\geq 12.5$ & $\ldots-\cdots-\cdots-\cdots$ \\
\hline
\end{tabular}




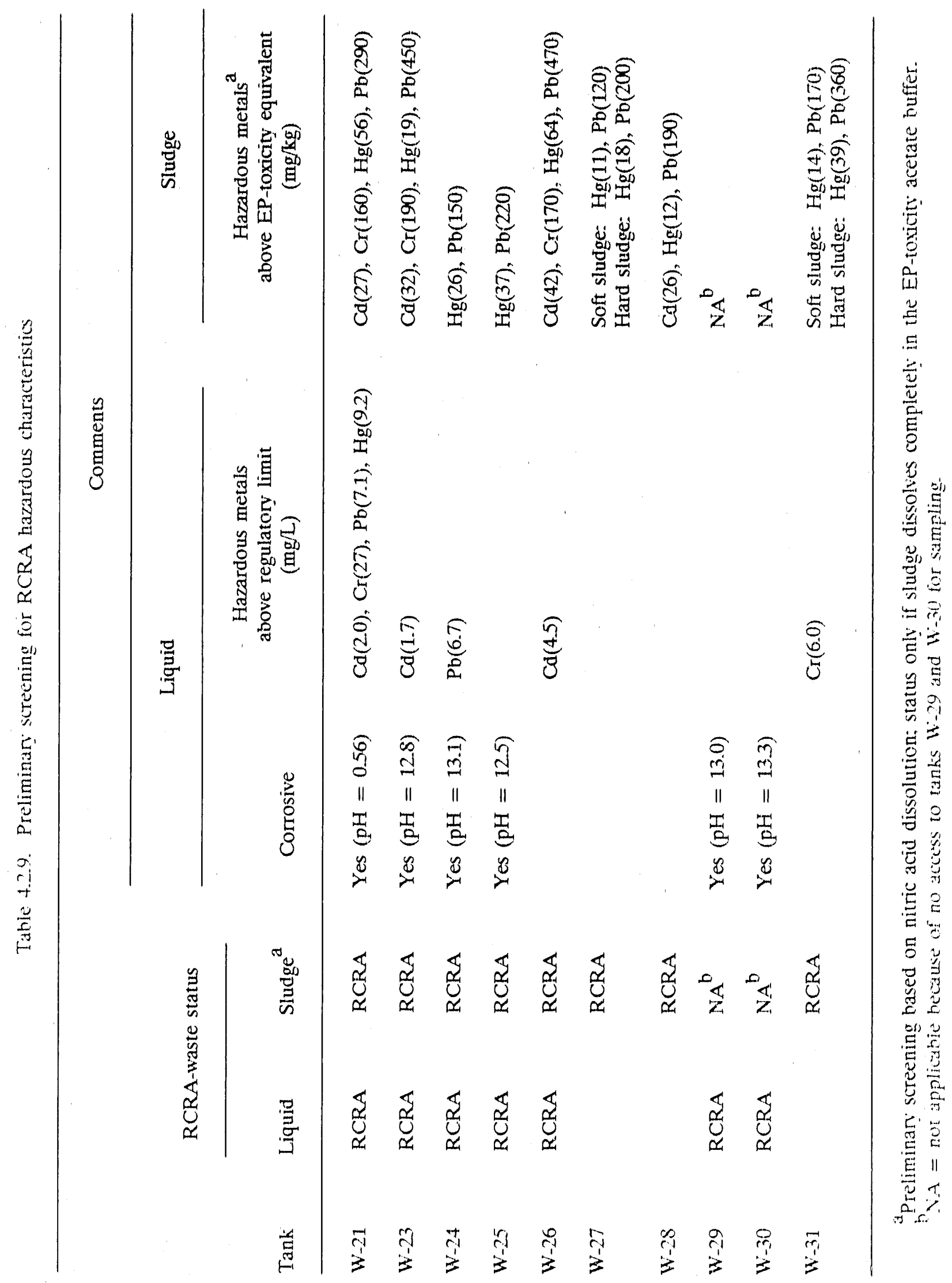


Characteristic Leaching Procodure (TCLP) results. Classilicalion is based on an lip. toxicity/TCLP equivalent. This is a value that accounts for the 2()-fold dilution of the EP. toxicity or TCLP procedures and ropresents the concentration that would resull in classification of the sample as RCRA hazardous waste if the sludge dissolved completely' in the acetate buffers used in these tests.

All sludge samples exceeded the EP-toxicily equivalent limits for mercury and lead. Samples from four tanks exceeded the EP-loxicity equivalent limit for cadmium: threc ol' them also exeeded the criterion for chromium. In general, arsenic, silver, selenium, and thallium were not lound at quantitative levels in the sludge. In the few exceptions, the values were very close to the reporting limits for the instrument.

Because of the high salt eontents of these wastes, it was not possible to mearsure selenium at the required levels by inductively coupled plasma spectrometry (ICP, SW-846, Method 6010). ${ }^{7}$ An elfort weas made to determine selenium in the liquid sumples firom tanks W-29 and W-30 by graphite furnace atomic absorption (GFAA). The high sodium nitrate levels were very corrosive to the graphite tube furnaces, and fewer than 20 sample injections could be completed before complete destruction of the graphite was observed. These difficulties are discussed in Appendix B, Secl. B.4.9.

Liquid samples from tanks W-29 and W-30) were analyzed for total cyanide using EPA Method 9010 modified for small samples. A substance in the waste interfered with the analysis (sec Appendix B, Sect. B.4.5). A new ion chromalograph, which is currenlly being installed, may resolve these questions for future waste samples.

\subsection{SUMMARY OF ORGANIC CHEMICAL CHARACTERIZATION}

A subset of samples from the waste tanks (W.24, $-2.5,-29,-30$, and .31 ) were analyzed for EPA Target Compound List (TCL) volatile and semivolatile organic compounds using modified EPA SW-846 methodologies (see Tables 4.3.1 and 4.3.2 for TCL. constituents and reporting limits). Decontaminated organic extracts were prepared by modifications of SW-846 Methods 5030) (volatiles in aqueous liquids) and 3510 (scmivolatiles in aqueous liquids) or 355 () (semivolatiles in sludges) in radioactive contamination-zoned facilities. The extracts were analyzed by Contract Laboratory Program (CLP) methods equivalent to SW-846 gas chromatography with mass spectromelty (GC/MS) Methods 8240 ) (volatiles) or 8270 (semivolatiles) in a conventional analytical laboratory. These analyses 
Table 4.3.1. Target Compound List volulle orgunles and reporting limils

Compound

Roporting limil

$(\mu \mathrm{g} / \mathrm{L}$.

Chloremelhane

Bromomethane

10

Vlnyl chloride

1)

Chlorocthane

10

Methylene chloride

10

Acolone

10

Carbon disullide

5

1,1. Dichloroethene

5

1,1-Dichlorocilane

1,2-1)ichlorocthene (lolal)

Chaloroform

1,2-Dichlorocthane

2-Butanone

1,1,1-Trichlorocthane

Carbon tetrachloride

Vinyl acclalce

Bromodichloromethane

1,2-Dichloropropane

Cis-1,3-dichloropropene

Trichlorocthene

Dibromoshloromethane

1,1,2-Trichlorecthane

Benzene

Trans-1,3-dichlorepropene

Bromolorm

4.Methyl-2-pentanone

2-Hexanone

Tetrachlorocthene

1,1,2,2-Tetrachlorocthane

Tholuene

Chlorelsenzene

Ethylberizene

Styrene

Xylene (totial)

5

5

5

5

10

5

5

10

5

5

5

5

5

5

5

5

5

1)

(1)

5

5

5

5

5

5

5 


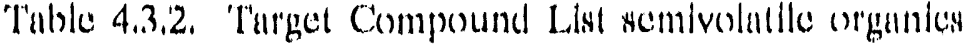
and reporting limits

\begin{tabular}{|c|c|c|c|}
\hline \multirow[b]{3}{*}{ Compound } & \multicolumn{3}{|c|}{ Reporting limits } \\
\hline & \multirow[b]{2}{*}{$\begin{array}{c}\text { Acpuosus sumple } \\
\left(\mu g / L_{L}\right)\end{array}$} & \multicolumn{2}{|c|}{ Sludge sumple } \\
\hline & & $\begin{array}{c}3-\mathrm{gg} \text { extract } \\
(\mu \mathrm{g} / \mathrm{kg})\end{array}$ & $\begin{array}{c}4 . g \text { exiracl } \\
(\mu \mathrm{g} / \mathrm{kg})\end{array}$ \\
\hline Phenol & 250 & 3.3()() & $2.501)$ \\
\hline Bis (2-chlorocthyl)ether & 25() & 3.300 & 2.5() 0 \\
\hline 2.Chlorophenol & 25() & 3.3() 0 & 2.5()$(1)$ \\
\hline 1,3-Dichlorobenzene & 25() & 3300 & $2.5(1)$ \\
\hline 1,4-Dichlorobenzene & 25() & $33(0)$ & $2.5(1)$ \\
\hline Benzyl uleoliol & 25() & 33()() & $2.5(1)()$ \\
\hline 1,2-Dichlorobenzene & 250 & $33(0)$ & $2.5(1)$ \\
\hline 2-Methylphenol & 250 & $33(1)$ & $25(1)$ \\
\hline Bis(2-chlorolsopropyl)ether & 250 & 33() 0 & $25(1)$ \\
\hline 4.Mcthylphenol & 250 & $33(0)$ & $2.5(1)$ \\
\hline NuNitros(o-di-Nupropylamine & 250 & 3.3()() & $25(1)$ \\
\hline Hexachlorocthane & 250 & 33() 0 & $2.5(1)$ \\
\hline Nitrobenzene & 25() & 3.300 & 2.5() 0 \\
\hline Isophorone & 25() & 3.3() 0 & 25()() \\
\hline 2-Nitrophenol & 250 & $33(1) 0$ & 25()() \\
\hline 2,4-Dimethylphenol & 250 & 33() 0 & 25()() \\
\hline Benzoic acid & 1300 & $17(0)(0)$ & 13()()$)$ \\
\hline Bis (2-chlorocthoxy) methane & 2.50 & 33()() & 25()() \\
\hline 2,4-Dichlorophenol & 250 & $33(1)()$ & 25()() \\
\hline 1,2,4-Trichlorobenzene & $250^{\circ}$ & $3.3(1)$ & $25(1)$ \\
\hline Naphthalene & 250 & 33() 0 & 25()() \\
\hline 4-Chloroaniline & 2.5() & $33(0)$ & $25(1)$ \\
\hline Hexachlorobutadiene & 25() & 3.3()() & 2.5()() \\
\hline 4-Chlore-3-methylphenol & 250 & $33(0)$ & 2.5()() \\
\hline 2-Methylnaphthalene & 250 & 33()() & 25()() \\
\hline Hexachlorocyclopentadiens: & 25() & $3.3(1)$ & 25()() \\
\hline $2,4,6$-Trichlorephenol & 25() & 3.3()() & 2.5()() \\
\hline 2,4,5-Trichlorophenol & 1.30() & 17()() & 1.3()()$(1)$ \\
\hline 2-Chloronaphthalene & 25() & 3.3()() & 2.5()() \\
\hline 2-Nitroaniline & 13() 0 & 17()()() & 1.3()$(0)$ \\
\hline Dimethylphthalute & 250 & 33()() & 2.5()() \\
\hline Acenaphthylene & 250 & 3.3()() & 2.5()() \\
\hline
\end{tabular}


Tublo 4.3.2 (continuod)

\begin{tabular}{|c|c|c|c|}
\hline \multirow[b]{3}{*}{ Compound } & \multicolumn{3}{|c|}{ Roporting Ilmits } \\
\hline & \multirow[b]{2}{*}{$\begin{array}{l}\text { Aqueous sumple } \\
\qquad(\mu \mathrm{g} / \mathrm{L})\end{array}$} & \multicolumn{2}{|c|}{ Sludge simple } \\
\hline & & $\begin{array}{l}3 \times g \text { extruct } \\
(\mu \mathrm{g} / \mathrm{kg})\end{array}$ & $\begin{array}{l}4 . g \mathrm{~g} \text { cxirucl } \\
(\mu \mathrm{g} / \mathrm{kg})\end{array}$ \\
\hline 2,6-Dinitrotoluene & 250 & $33(x)$ & 250() \\
\hline 3-Nitroaniline & 1300 & $17(0)$ & $1.30(0)$ \\
\hline Acenuphthene & 25() & 3300 & 2500 \\
\hline 2,4-Dinitrophenol & $13(x)$ & $170(5)$ & $130(0)$ \\
\hline 4-Nilrophonol & $13(k)$ & 1700 & $13(0)(0)$ \\
\hline Dibenzofuran & 250 & $3.3(1)$ & 250() \\
\hline 2,4-Dinitrotoluene & 250 & 3300 & $25(1)()$ \\
\hline Dlethylphthalatc & 250 & $33(k)$ & 2500 \\
\hline 4. Chlorophenylphenylether & 2.50 & $3,3(1)$ & 250() \\
\hline Fluorene & 250 & $33(k)$ & $250(0)$ \\
\hline 4-Nitroaniline & 1300 & $170(0)$ & $13(0) 00$ \\
\hline 4,6-Dinitro-2-mathylphenol & $13(k)$ & $170(k)$ & $13(x)(0)$ \\
\hline N-Nitrosodiphenylamine ${ }^{a}$ & 250 & $33(k)$ & 2500 \\
\hline 4-Bromophenylphenylether & 250 & $3.3(x)$ & 250() \\
\hline Hexachlorobenzene & 250 & $3.3(K)$ & 250() \\
\hline Pentuchlorophenol & 1700 & $17(x)$ & 13()()() \\
\hline Phenanthrene & 250 & $33(x)$ & 25()() \\
\hline Anthracence & 250 & $33(10)$ & 25() \\
\hline Di-n-bulylphthalate & 25() & $33(x)$ & 25() 0 \\
\hline Fluorunthene & 250 & 3.300 & 2500 \\
\hline Pyrene & 250 & $33(x)$ & 25()() \\
\hline Butylbenzylphthalate & 250 & $3.3(x)$ & 25()() \\
\hline 3,3 Dichlorobenzidine & $5(K)$ & $67(x)$ & 5()$(1)$ \\
\hline Benzo(a)anthracene & 250 & $3.3(k)$ & 25()() \\
\hline Chrysene & 250 & $3.3(k)$ & 25()() \\
\hline Bis(2-cthylhexyl)phthalate & 250 & $33(x)$ & 250() \\
\hline Di-n-octylphthalate & 25() & 3.3()() & 25() 0 \\
\hline Benes(b)fluoranthene & 250 & $33(x)$ & 25()() \\
\hline Benzo(k)fluoranthene & 250 & $3.3(x)$ & 25()() \\
\hline Benzo(a)pyrene & 250 & $3.3(K)$ & $25(1)$ \\
\hline Indeno(1,2,3-cd)pyrene & 250 & $3.3(1)$ & $25(1)$ \\
\hline Dibenz(a,h)anthracene & $25(x)$ & 33()() & 25()() \\
\hline $\operatorname{Benzo}(g, h, i)$ perylene & 25() & $3.3(x)$ & 2.50() \\
\hline
\end{tabular}

"Cannot be resolved from diphenylamine. 


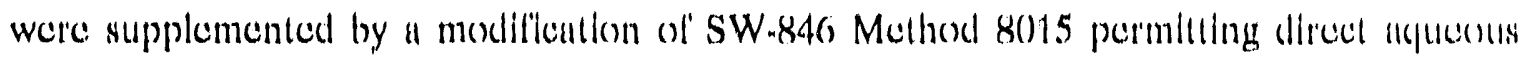
Injection gas chromatographic (DAICC) decermination of majer water-soluhle organic compounds that are not amenable to purgenand-trap GC/MS.

Very f'ew EPA TCL compounds were found in the waste samples. Resulls are shown in Tables 4.3.3 and 4.3.4 lor the volatile and semivolatile organis compononds, respectively. These tables list only eompounds whose possible prescence was indicaled by the analysis. No volatile organics attributable to the samples were determinod by the purge-andintrap GC/MS or by DAIGC procedures with reporting limits of 5 (o $10 \mu \mathrm{k} / \mathrm{l}$. and 1 to $2 \mathrm{mg} / \mathrm{L}$, respectively. The volatile compounds methylene chloride, acetone, and colucenc: wore found in cach of the lank samples but were also observed in blanks at similar concentrations and thus cannot be attributed to the aqueous samples. Semivolatile phthalates, which are almost ublquitous in nature, were present in the sludge samples and some liquid samples. Phthalates were also present in relatively high concentrations in the water and sand blanks. The main TCL hit was the semivolatile organic compound benzoic acid (40 to $35(K) \mu \mathrm{g} / \mathrm{L}$ ). Naphthalene and phenanthrene were found (40) $10520 \mu \mathrm{g} / \mathrm{kg}$ ) in two sludges. Most of the organic matter was found as Tentatively Identilied Compounds (TICs). The main TICs were not identiliable, but 2,6-dibromo-4-nitrophenol was estimated at 600$)$ to $20(0) \mu \mathrm{g} / \mathrm{L}$. Tributyl phosphate was only found in the solt sludge $(1900 \mu \mathrm{g} / \mathrm{kg})$ and the hard sludge $(12,(5) 0 \mu \mathrm{g} / \mathrm{kg})$ of tank W-31. Dimethylbenzene and diethylbenzene also were detected in a lew samples. Polychlorinated biphenyls were not specilically determined, but they would have been estimated as T'ICs. Reporting limits for individual polychlorinaled biphenyl cogeners (not Aroclor mixtures) were cach $2.5 \mathrm{mg} / \mathrm{L}$ for alyueous liquids and $131017 \mathrm{mg} / \mathrm{kg}$ for sludges. Recoveries of surrogate standards and matrix spikes were generally good and consistent with previous experiences with nuclear wastes.

Very little (4 10 14\%) of the organic natter suggested to be present by tolal organic carbon analyses was aceounted for by the regulatory organics decterminations. The remainder may consist of highly polar, walcr-soluble, and possibly polymeric compounds arising from the radiolysis and degradation of chelators, extractants, or other compounds originally present in the wastes. Ictentilication of these eompounds would require lurther development and application of the analytical methods. 


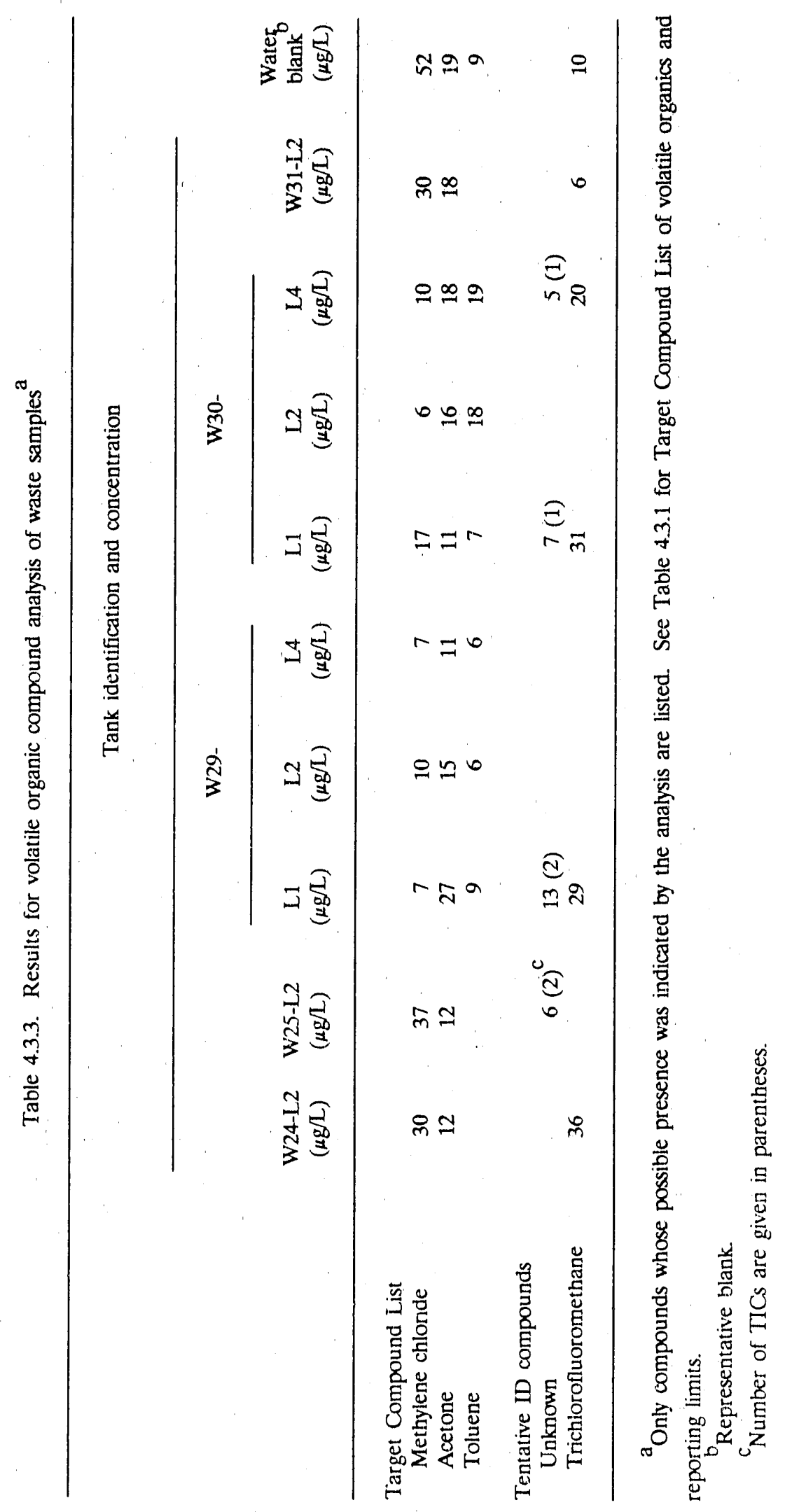


61

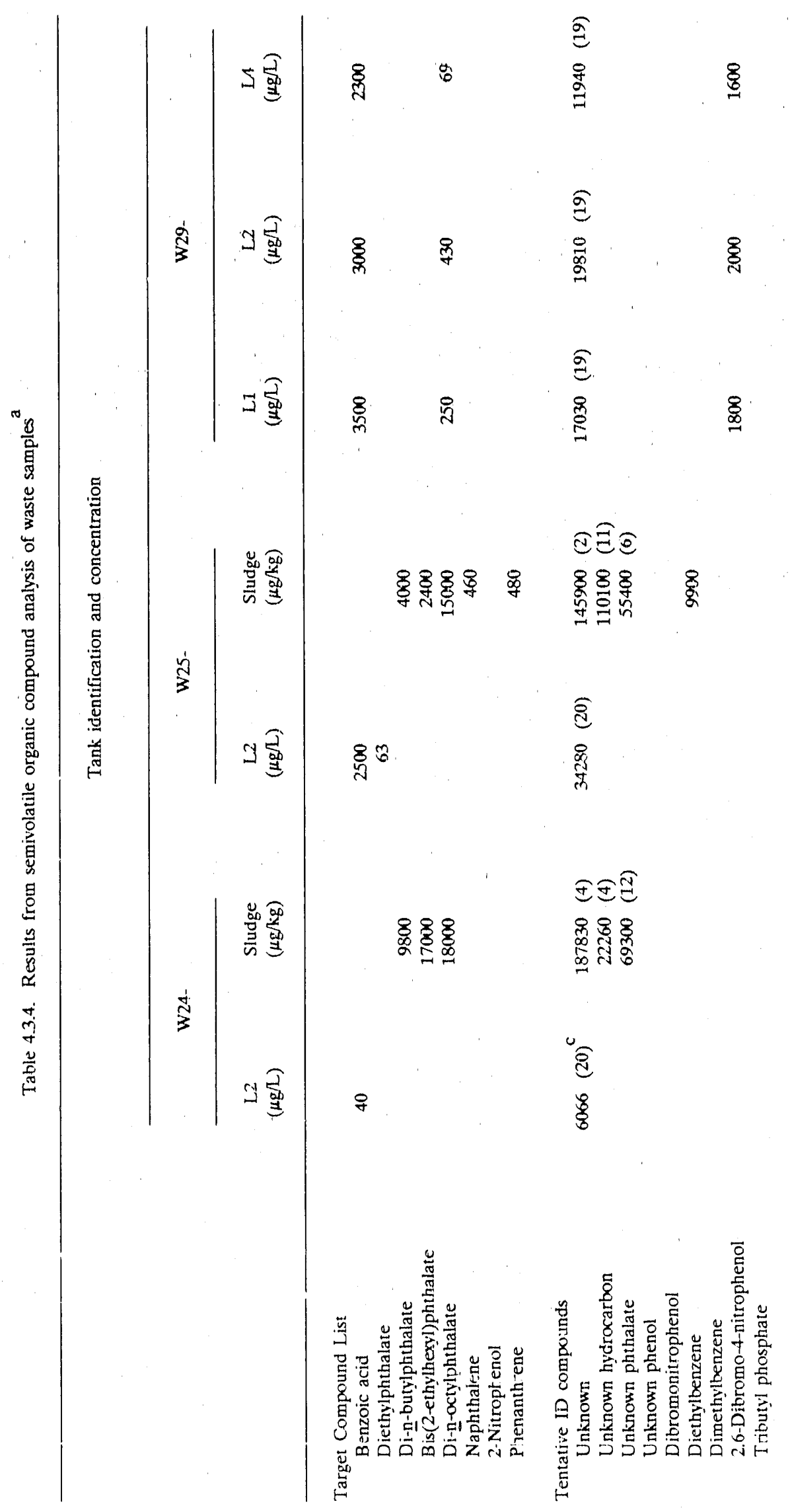




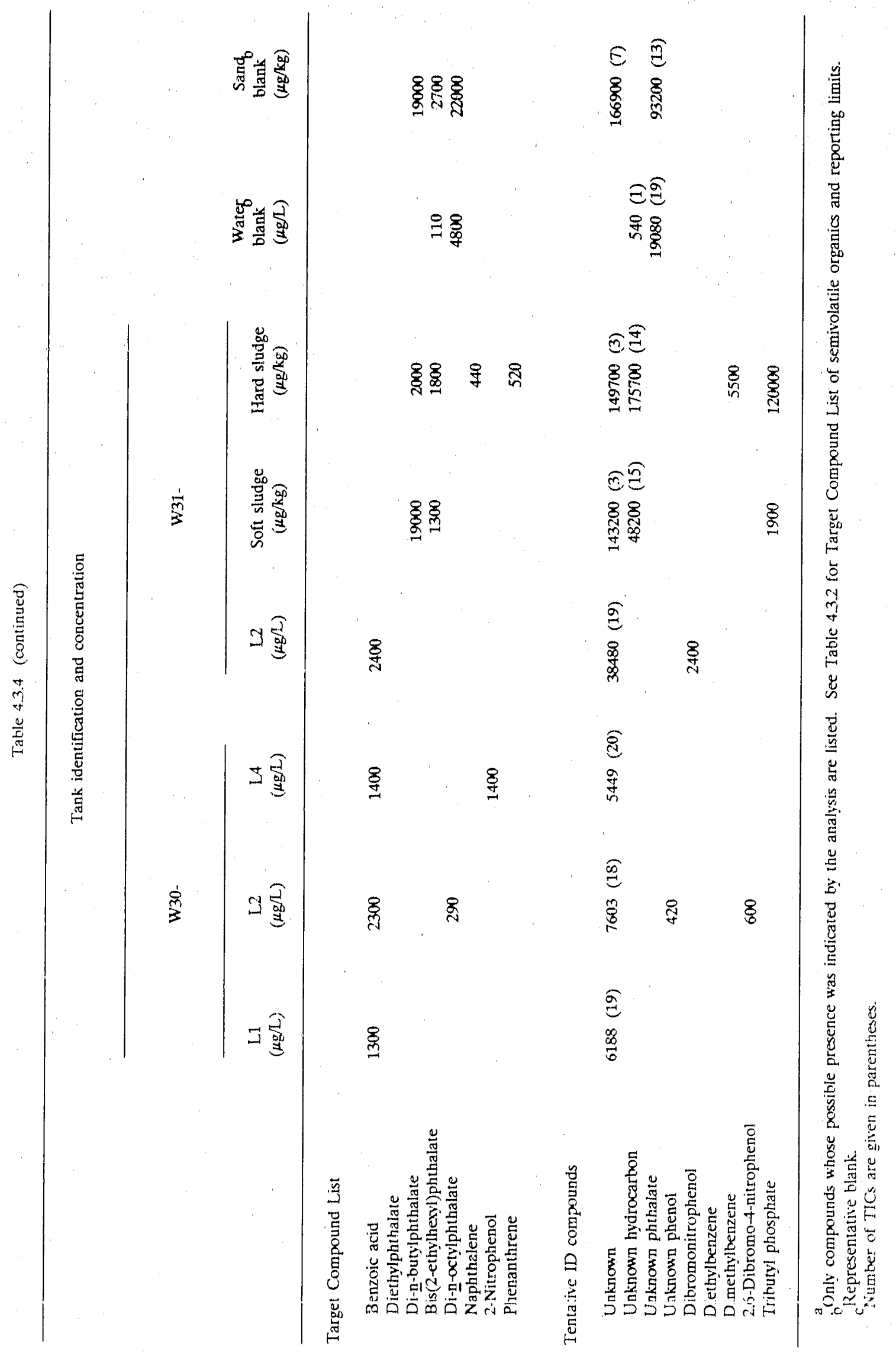


Additional information on the organic chemical characterization is presented in Appendix D; a brief description of the analytical methods and a more extensive discussion of the results are also included.

\subsection{DISCUSSION AND RECOMMENDATIONS}

This study provides a relatively extensive characterization of the liquid wastes in the tanks in the winter of 1989-1990. The in-tank-evaporation project using air sparging of the MVSTs, which was started shortly after the samples had been taken, may cause shifts in equilibrium related to $\mathrm{pH}$ and carbonate as carbon dioxide is absorbed from the air, in addition to concentrating the wastes. The general properties of the supernates will probably continue to be similar, but some changes in composition should be expected with time.

In this study, sludge samples could be collected at only one location in each tank (i.e., directly under the aceess pipe); remote equipment was not available to examine other locations. Therefore, the sludge data should be regarded as merely an indicator of the tank contents. Statistical sampling of these tanks, as defined by EPA SW-846, is not possible because of the high radiation levels and limited access. Results of the study provide a relatively extensive characterization of the metals and radioactive materials in the sludge samples. Although not determined in this study, it is recommended that both ${ }^{99} \mathrm{Tc}$ $\left(\mathrm{t}_{1 / 2}=2.13 \times 10^{5} \mathrm{y}\right)$ and ${ }^{129} \mathrm{I}\left(\mathrm{t}_{1 / 2}=1.6 \times 10^{7} \mathrm{y}\right)$ be determined on selected samples. However, the determination of anions within the sludge phase of the waste tanks is a

problem area. Some preliminary washing tests and dilute acid leaching of the sludge are planned. This might provide some information about anions which are soluble in water or dilute acid (e.g., the anions in the interstitial liquid). Considerable development work may be required to obtain useful anion data.

About $90 \%$ of the organic carbon compounds determined by the total organic carbon analysis were not accounted for by the EPA regulatory procedures. The application of high-performance liquid chromatography might yield information about the possible presence of low-molecular-weight organic acids/salts (e.g., oxalates, acetates, butyrates). This would require a special column for the new ion chromatograph as well as methods development. Considerable additional development and application of analytical methods would be required to identify other types of organic compounds such as radiolytical and chemical degradation products. 
This study was primarily focused on support for WHPP design and included only a preliminary RCRA characterization. The full RCRA characterization will be needed in the future.

The EPA regulatory procedures for solid wastes were not designed for radioactive wastes or the types of chemical matrices found in the waste tanks. There is a need for greater flexibility and modifications in the regulatory procedures to give a high priority to worker health and safety [e.g., As Low As Reasonably Achicvable (ALARA)]. This is especially true in cases where the spirit and intent of environmental regulations can be satisfied technically using alternative procedures. With the current visibility that DOE facilities are receiving on health and safety practices, it is becoming increasingly diflicult, if not impossible, to satisfy some of the EPA regulatory procedures. In this study, modifications were made in the EPA procedures to reduce worker exposure; however, there has been no agreement that these modifications will be acceptable for compliance purposes. Many of these modifications involved reduced sample size, which also reduces the amount of contaminated waste requiring disposal from sampling and laboratory activities.

Some additional issues must be considered along with ALARA requirements. Some holding time requirements (e.g., mercury, volatile organics, and cyanide) are unrealistic since radiological data must be obtained on all samples prior to other measurements 10 ensure that activity limits are maintained in various laboratories. The volumes (sample sizes) required and/or suggested for various analytical measurements (volatile and semivolatile organic compounds, EP-TOX, TCLP, cyanide and sulfide distillations) are unacceptable for the levels of activity involved. On-site filtration and acid preservation are unaceptable for field operations with radioactive samples since these operations would result in unnecessary radiation exposures to personnel. Required measurements on undiluted samples are unaceeptable for the levels of activity involved. The drying of samples for dissolved solid determinations creates an extreme hazard due to possible dusting. The QA/QC requirements (duplicates, spikes, etc.) for nonautomated procedures result in additional radiation exposure to personnel.

Some of the EPA regulatory procedures do not work on the chemical matrices found in the waste tank samples. For example, GFAA for metals and the EPA cyanide procedure do not work. 
There is a need for specialized analytical instrumentation (capital equipment) to meet the needs for regulatory characterization of radioactive samples. The analytical equipment includes items such as an inductively coupled plasma-mass spectrometer (ICP-MS) for more efficient and sensitive measurement of metals and isotopes, a gats chromatograph-mass spectrometer (GC-MS) for volatile and semivolatile organics determination on radioactive samples, and a liquid chromatograph-mass spectrometer (LCMS) for identification and measurement of polar organic compounds.

\subsection{REFERENCES}

1. R. N. Ceo and J. T. Shor, Physical Characterization of Radioactive Sludges in Selected Melton Valley and Evaporator Facility Storage Tanks, ORNL/TM-11653, in preparation.

2. J. J. Maddox, Oak Ridge National Laboratory, personal communication, August 3, 1990.

3. R. C. Merritt, The Extractive Metallurgy of Uranium, Colorado School of Mines Rescarch Institute, 1971, pp. 85, 227.

4. F. J. Peretz, B. R. Clark, C. B. Scott, and J. B. Berry, Characterization of LowLevel Liquid Wastes at the Oak Ridge National Laboratory, ORNL/TM-10218, December 1986.

5. D. A. Costanzo, Oak Ridge National Laboratory, personal communication to $M$. B. Scars, Mar. 23, 1989.

6. U.S. Department of Energy, DOE Order 5820.2A, "Radioactive Waste Management."

7. U.S. Environmental Protection Agency, Test Materials for Evaluating Solid Waste, SW.846, 3rd ed., Office of Waste and Emergency Responses, Washington, D.C., November 1986. 
APPENDIX A

FIELD SAMPLING DATA 


\section{INTRODUC'TION}

Field sampling data are presented in this appendix. The dala are from the perspective of the sampling erew slanding on the pad ovel the lank, with distancess measured from the flange on the access pipe down into the lanks. Prolites of the tank conlents are presented in Table A.1. The paramelers were determined as follows:

1. Locations of the air-liquid and liquid-sludge interfinces as measured with the Markland detectori;

2. location of the tank botlom messured by pushing a rod (i.e., the simpling equipment) down into the tank and measuring the length on the red;

3. location of the lop ol the settled sludge solids layer derived from the height of the sludge solids phase in the sample collected at the licjuid-sludge inlerface (meatsured in the analytical laboratory, sece Appendix B, Table B.3, "S1" code samples) and the locallion where the sample was collected (Table A.3);

4. Iocation of any hard-sludge layer measured by pushing the solt-sludge siampler into the tank until a consolidated layer was reached; and

5. calculated values for the one-third, one-half, and (wo-thirds liquid levels in the lanks, based on the presampling survey with the Markland detector.

A comprehensive listing of the samples collected, dates of collection, sampling locations in the tanks, and field survey radiation levels is presented for the liquid and sludge samples in Tables A.2 and A.3, respectively.

The estimated personnel exposures (pocket-meter readings) from lield sampling activities are given in Table A.4. 'The doses received during the collection of 18 licpuid samples (0.1 to $1.2 \mathrm{R} / \mathrm{h}$ ) at the MVSTs using the vacutum pump sampling system were aboul the same as those received during collection of 8 liguid samples $(0.1 \mathrm{R} / \mathrm{h})$ using the pump module (Isolock) system, including the maintenance to make the system operaltionall. 'The doses from sampling tanks at the cvaporator service lacility are higher than those firom sampling the MVST's because "hol" piping/ductwork near the access to lank W-21 makes the work-area radiation levels higher around that lank (and also tank W-22, which was nol part of this study). The doses to the hand (finger ring dosimelers) were about the sime as these from handling MVSTs samples. Tank W-23, also localed at the evalporater liacility, is in a differenil valult. 


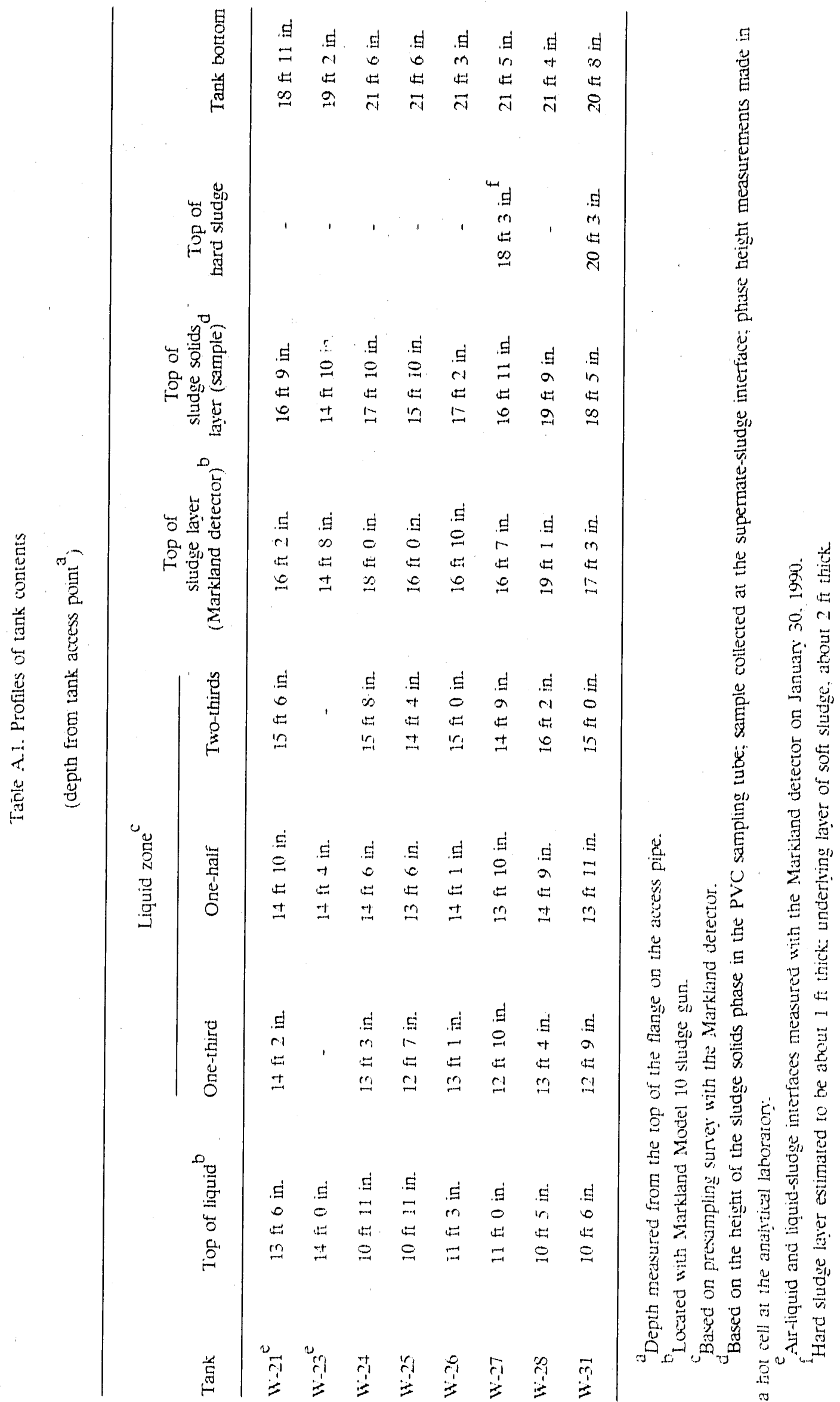


Table A.2. rikeld informallon for llepuld sumples

\begin{tabular}{|c|c|c|c|c|c|}
\hline l'ank & Sumple & $\begin{array}{c}\text { Dulle } \\
\text { colleciled }\end{array}$ & $\begin{array}{l}\text { Liguld level } \\
\text { sumpled }\end{array}$ & $\begin{array}{l}\text { Sampllng depth } \\
\text { from lank } \\
\text { acress poinl" }\end{array}$ & 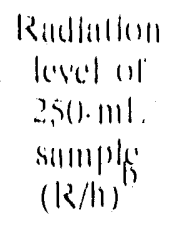 \\
\hline$W .21$ & $\begin{array}{l}W 21 \cdot 1.1 \\
W 21 \cdot 1.2 \\
W 21 \cdot 1.3\end{array}$ & $\begin{array}{l}1 / 3(1 /(9) \\
1 / 3(1)(9) \\
1 / 3(1)(9)\end{array}$ & $\begin{array}{l}\text { Onc-lhird } \\
\text { Once-hall } \\
\text { Two-lhirds }\end{array}$ & $\begin{array}{l}14 \| 2 \mathrm{ln} . \\
14 \| 10 \mathrm{ln} . \\
1506 \mathrm{in.}\end{array}$ & $\begin{array}{l}(0.310) \\
(0.31)(1) \\
(1.3(1))\end{array}$ \\
\hline$W-2.3$ & IW2.3-1.1 & $1 / 3(1 /(9)$ & Onc-half & $14 \mathrm{li}+\mathrm{in}$. & 1.1211 \\
\hline$W .24$ & $\begin{array}{l}W 24-1.1 \\
W 24-1.2 \\
W 24-1.3\end{array}$ & $\begin{array}{l}0 / 19 / 80 \\
0 / 19 / 89 \\
(y / 19 / 89)\end{array}$ & $\begin{array}{l}\text { One-lhird } \\
\text { Onc-hall } \\
\text { Tw(1)-lhinds }\end{array}$ & $\begin{array}{l}1.3 \mathrm{ll} .3 \mathrm{ln} . \\
1.4 \mathrm{li} 6 \mathrm{ln} . \\
1.5118 \mathrm{in.}\end{array}$ & $\begin{array}{l}0.1201 \\
0.18181 \\
0.1801\end{array}$ \\
\hline$W-25$ & $\begin{array}{l}W 25-1.1 \\
W 25.1 .2 \\
W 25-1.3\end{array}$ & $\begin{array}{l}9 / 19 / 89 \\
9 / 19 / \$ 9 \\
9 / 19 / 89\end{array}$ & $\begin{array}{l}\text { One-hird } \\
\text { One-half } \\
\text { 'lwo-lhirds }\end{array}$ & $\begin{array}{l}12 \| 7 \mathrm{in.} \\
1.3116 \mathrm{in.} \\
14 \mathrm{in}^{4} 4 \mathrm{in.}\end{array}$ & $\begin{array}{l}0.1(1) \\
0.28(1) \\
0.2(1)\end{array}$ \\
\hline W-26 & $\begin{array}{l}\text { W26-1.1 } \\
\text { W20-1.2 } \\
\text { W20-1.3 }\end{array}$ & $\begin{array}{l}9 / 19 / 89 \\
9 / 19 / 89 \\
9 / 19 / 89\end{array}$ & $\begin{array}{l}\text { One-third } \\
\text { One-half } \\
\text { Two-thirds }\end{array}$ & 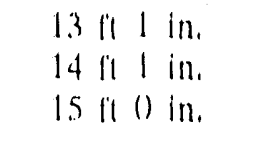 & $\begin{array}{l}1.2(1) \\
1.2(1) \\
1.2(1)\end{array}$ \\
\hline W.27 & $\begin{array}{l}W 27.1 .1 \\
W 27-1.2 \\
W 27-1.3\end{array}$ & $\begin{array}{l}y / 19 / 8(9) \\
\left.y / 19 / R^{\prime}\right) \\
\left.y / 19 / \mathrm{S}^{\circ}\right)\end{array}$ & $\begin{array}{l}\text { Onc-third } \\
\text { One-hall } \\
\text { Two-thirds }\end{array}$ & $\begin{array}{l}12 " 10 \mathrm{in} . \\
1.3 \mathrm{ll} 10 \mathrm{in} . \\
14 \mathrm{ll} 9 \mathrm{in.}\end{array}$ & $\begin{array}{l}0.1(0) \\
0.2(1) \\
0.1(0)\end{array}$ \\
\hline$W-28$ & $\begin{array}{l}\text { W28-1.1 } \\
\text { W2s-1.2 } \\
\text { W28-1.3 }\end{array}$ & $\begin{array}{l}9 / 19 / 80 \\
9 / 19 / 80 \\
9 / 19 / 89\end{array}$ & $\begin{array}{l}\text { One-third } \\
\text { One-hall' } \\
\text { 'Tw()-hirds }\end{array}$ & $\begin{array}{l}1.3 \mathrm{ll} 4 \mathrm{in.} \\
14 \mathrm{fl} 9 \mathrm{in.} \\
16 \mathrm{ll} 2 \mathrm{in.}\end{array}$ & $\begin{array}{l}(1.50)(1) \\
(1.480) \\
(1.480)\end{array}$ \\
\hline$(V-2)$ & $\begin{array}{l}W 29-1.1 \\
W 29-1.2 \\
W 29-1.3 \\
W 29-1.4\end{array}$ & $\begin{array}{l}11 / 3(1) / 89 \\
11 / 3(0) / 89 \\
11 / 30 / 89 \\
11 / 3(0) / 89\end{array}$ & . & $\begin{array}{l}d \\
d \\
d \\
d\end{array}$ & $\begin{array}{l}0.1110 \\
0.1101 \\
0.1111 \\
0.1111\end{array}$ \\
\hline$W-3()$ & $\begin{array}{l}W .3()-1.1 \\
W .3()-1.2 \\
W .3(1)-1.3 \\
W .3(1) \cdot 1.4\end{array}$ & $\begin{array}{l}11 / 3(1) / 80 \\
11 / 3(1) / 80 \\
11 / 3(1) / 89 \\
11 / 3(1)(39)\end{array}$ & . & $\begin{array}{l}d \\
d \\
d \\
d\end{array}$ & $\begin{array}{l}0.110 \\
0.110) \\
0.110 \\
0.110\end{array}$ \\
\hline W. .31 & $\begin{array}{l}\text { W.31-L.1 } \\
W .31-1.2 \\
W .31-1.3\end{array}$ & $\begin{array}{l}0 / 10 / 80 \\
0 / 10 / 80 \\
y / 10 / 80\end{array}$ & $\begin{array}{l}\text { Onc-third } \\
\text { Onc-half } \\
\text { 'lw'-thirds }\end{array}$ & $\begin{array}{l}12119 \mathrm{in} . \\
1.31111 \mathrm{in.} \\
1.5110 \mathrm{in.}\end{array}$ & $\begin{array}{l}(1.190) \\
0.1801 \\
0.1801\end{array}$ \\
\hline
\end{tabular}

"Depth measured from the lop of the liange on the alecessip pipe.

Ficeld survey.

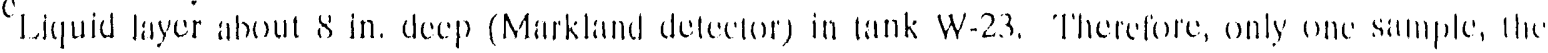
midpeint sample, was collected.

Sample collected using the pump module sampler. Pump plekup is all onc-hall the tank alephth. There is no access (o) lanks W-20 and W-30 for measuring sludge depth. 


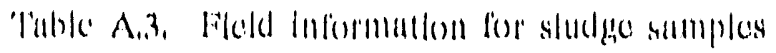

\begin{tabular}{|c|c|c|c|c|c|c|}
\hline 'lank & Simple/luyer & $\begin{array}{l}\text { Dute sumple } \\
\text { collected }\end{array}$ & $\begin{array}{l}\text { 'Type of' } \\
\text { sumple }\end{array}$ & $\begin{array}{l}\text { Depuln from lunk } \\
\text { access polnt }\end{array}$ & 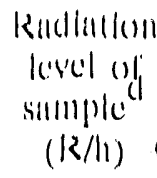 & (') (c)mmsinls \\
\hline \multirow[t]{3}{*}{ W.21 } & 'Top of' solle sludge & & & $16112 \mathrm{in.}$ & & \\
\hline & $W 2 \mid-S 1$ & $1 / 31 / 9(1)$ & Sofl sludge & 17 ll I0 ill. & 1.5 & \\
\hline & W2I-S2 & $1 / 31 / 9()$ & Soflt sludge & $\begin{array}{l}\text { Is It II ln. } \\
\text { (lunk bott(om) }\end{array}$ & $1.1)$ & 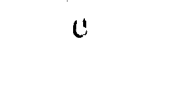 \\
\hline \multirow[t]{4}{*}{$W-23$} & Top of soft sludge & & & 14118111. & & \\
\hline & W2.3-S1 & $1 / 31 / 90$ & Soll sludge & $1611+4 \mathrm{ln}$ & 2.5 & \\
\hline & W23.S2 & $|/ 3| / 90$ & Sollt siludge & Is It () III. & $2 .(1)$ & \\
\hline & W2.3-S.3 & $1 / 31 / 9()$ & Solt sludge & $\begin{array}{l}\text { 19) Il } 2 \text { In. } \\
(\text { lunk: hollom) }\end{array}$ & $1,()$ & \\
\hline \multirow[t]{3}{*}{$W-24$} & Top of solt sludge & & & $18 \mathrm{ll} 0 \mathrm{in}$ & & \\
\hline & W2.4-S1 & $9 / 21 / 89$ & Solt sludge & 181110111. & $(1,10)$ & \\
\hline & $W 24 \cdot S 2$ & $y / 21 / 89$ & Soft sludge & $\begin{array}{l}21 \text { li o in. } \\
\text { (lank bollomin) }\end{array}$ & 1.2 & \\
\hline \multirow[t]{4}{*}{$1 W .25$} & lop of solt sludge & & & $16110 \mathrm{ln}$. & & \\
\hline & W2.5-SI & $9 / 21 / 89$ & Solt sludge & $17 \mathrm{ft}+\mathrm{in}$. & $(0.50)(0)$ & \\
\hline & W2.5.S2 & $9 / 21 / 89$ & Soft sludge & $18119 \mathrm{in.}$ & $(0.5())$ & \\
\hline & W25-S.3 & $9 / 21 / 89$ & Solt sludge & $\begin{array}{l}21 \text { ll o in. } \\
\text { (lank bollom) }\end{array}$ & 1.3 & \\
\hline \multirow[t]{4}{*}{$W-26$} & Top of softi sludge & & & $161110 \mathrm{in}$. & & \\
\hline & W20.S1 & $12 / 5 / 84$ & Soft sludge: & 18 ll $6 \mathrm{in.}$ & $2.1)$ & \\
\hline & W26-S2 & $12 / 5 / 80$ & Soft sludge & 20) $l 101 \mathrm{ln}$. & 10,8 & \\
\hline & $W_{2}(0-S 3$ & $12 / 5 / 80$ & Soft sludge & $\begin{array}{l}21 \mathrm{fl} 3 \mathrm{in.} \\
\text { (lank bollom) }\end{array}$ & 1.2 & \\
\hline \multirow[t]{5}{*}{$1 W-27$} & Top of soli sludge & & & $16 \mathrm{ll} 7 \mathrm{in.}$ & & \\
\hline & W27-S1 & $9 / 21 / 80$ & Solt sludge & $17 \mathrm{ll} 6 \mathrm{ln}$ & $(0.1(1)$ & \\
\hline & $W 27-S 2$ & $12 / 5 / 80$ & Solt sludge & l'o hilld sludge & ().2 & l' \\
\hline & T'op of hard studge & $9 / 21 / 80$ & & $18 \mathrm{li} .3 \mathrm{in.}$ & & \\
\hline & W27-H1 & $12 / 5 / 89$ & Hard sludge & $\begin{array}{l}21 \text { li } 6 \mathrm{in.} \\
\text { (tank bollom) }\end{array}$ & $(0.3$ & $g$ \\
\hline \multirow[t]{3}{*}{ W. 28} & Top of solt sludgec & & & $19111 \mathrm{in.}$ & & \\
\hline & $\mathrm{W} 28 \cdot \mathrm{S} 1$ & $9 / 21 / 89$ & Soft sludge & $\begin{array}{l}21 \mathrm{ll} 4 \mathrm{in} . \\
(l a n k \text { boll(om) }\end{array}$ & 1.2 & \\
\hline & W2B-S2 & $9 / 21 / 89$ & Soft sludge & $\begin{array}{l}21 \mathrm{fl} \text { if in. } \\
(\text { lank boll()m) }\end{array}$ & $(1.8$ & $\|$ \\
\hline
\end{tabular}


I'uble: $A .3$ (comlnnude)

\begin{tabular}{|c|c|c|c|c|c|}
\hline 'lank & Sumple/layer & $\begin{array}{l}\text { Dute sumple } \\
\text { colleceled }\end{array}$ & $\begin{array}{l}\text { 'Type of' } \\
\text { sample }\end{array}$ & $\begin{array}{l}\text { Depell from lynlk } \\
\text { ucecess prolum }\end{array}$ & 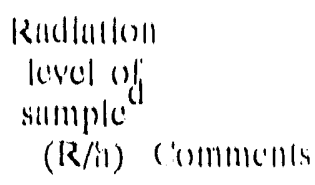 \\
\hline$W-31$ & 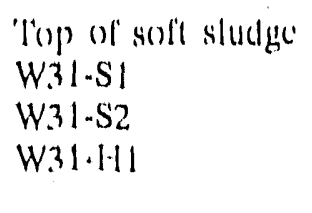 & $\begin{array}{l}9 / 27 / 89 \\
9 / 27 / 89 \\
9 / 27 / 89\end{array}$ & $\begin{array}{l}\text { Soll sludge } \\
\text { Sollt sludge } \\
\text { Hurd sludge }\end{array}$ & 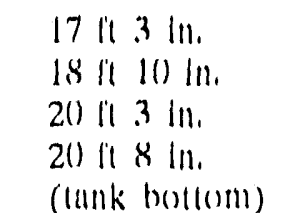 & $\begin{array}{l}1.5 \\
2.2 \\
2.8\end{array}$ \\
\hline
\end{tabular}

"Depen measured from the top of the flange on the aecess plpe.

bliculd-sludge interline leculed with the Markland detecion.

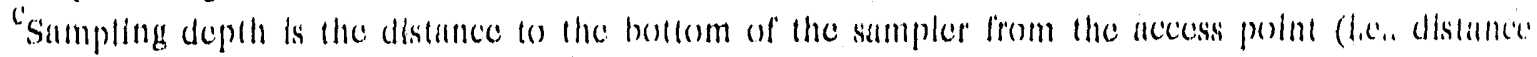
S1, $S_{2}$, , . . shown in $[1 \mathrm{lg}, 3,1,3)$.

Pirild survey,

'An older design sampler used which collected a shorler core (15 In.) than the others.

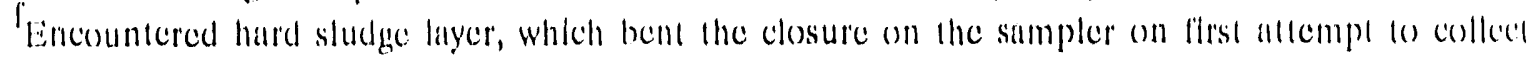
sample W27-S2 (9/21/89); no sample was collected at that time. Wont back 12/5/89 lo sample llis liank. Simple W27.S2 overlaps the solids layer of sample W27-S1.

BAuger bit cut through an estimated 1-fi-lhick layer of hard situdge, then pushed sampler through underlying solt layer lo tank bollom. Hard sludge plagged the sampler; a simple of the underlying soll lilyer wass nol oblained.

heollected a second sample al same focallion to shtaln more mulcrial. 
APPENDIX B

INORGANIC AND RADIOCHEMICAL ANALY'TICAL SUPPOR'I' 


\section{APPENDIX B CONTEN'IS}

B.1 INTRODUCTION $\ldots \ldots \ldots \ldots \ldots \ldots \ldots \ldots \ldots \ldots \ldots, 1, .5$

B.2 INITIAL SAMPLE HANDLING $\ldots \ldots \ldots \ldots \ldots \ldots \ldots \ldots, \ldots, \ldots$

B.2.1 Lequid Sumples . . . . . . . . . . . . . . . . . . . B.4)

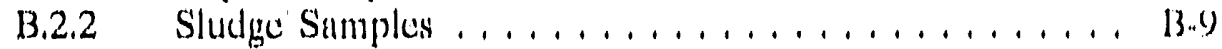

B.3 ANALYTICAL METHODOLOGY $\ldots \ldots \ldots \ldots \ldots \ldots \ldots \ldots, 13-14$

B.4 INORGANIC AND PHYSICAL MEASUREMENTS , . . . . . , B.14

B.4.1 Sample Preparation for Metal Analysis . . . . . . . . . B.14

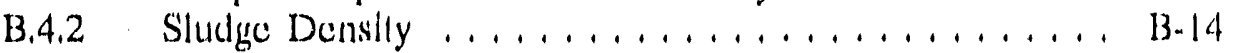

B.4.3 Common Antons . . . . . . . . . . . . . . . . . . B.19

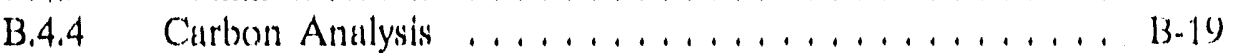

B.4.5 Cyanides ... . . . . . . . . . . . . . . . . B B.20

B.4.6 Motal Analysis by Inductively Coupled Plasma

Alomic Emission Spectroseopy (ICP.AES) . . . . . . . 13-20

B.4.7 Sample Preparation for Morcury Analysis ........, B.21

B.4.8 Mercury Analysis by Cold Vapor Technique . . . . . . B B.21

B.4.9 Metal Anulysis by Graphite Furnace Alomic Absorption (GFAA) . . . . . . . . . . . . . $13-22$

B.4.10 QA/QC Data and Comments for Metal Anulysis . . . . B. B.2.3

B.5 RADIOCHEMICAL MEASUREMENTS $\ldots \ldots \ldots \ldots \ldots \ldots$ B.28

B.5.1 Sample Preparation for Alpha Counting . . . . . . . B. 28

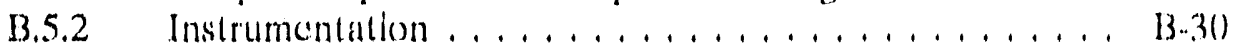

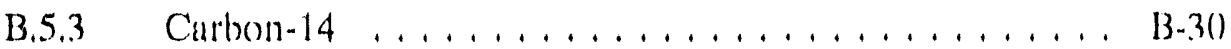

B.5.4 Qunlity Control ................... B-31

B.6 REFERENCES $\ldots \ldots \ldots \ldots \ldots \ldots \ldots \ldots \ldots \ldots \ldots \ldots, \ldots, \ldots, \ldots \ldots$ 


\section{INORGANIC AND RADIOCHEMICAL ANALYTICAL SUPPORT}

\section{B.1 INTRODUCTION}

The objective of this project was to characterize the concentrates from the liquid low-level wastes (LLLW) generated at the Oak Ridge National Laboratory (ORNL). The historical information and the various sources of waste are discussed in Sect. 2 of this report. Since information obtained from these studies will be used in support of various activities, standardized analytical procedures were used as much as possible for all measurements. ${ }^{1-3}$ Some modifications to the standard procedures were necessary because of the high radiation level, high salt content, and generally complex chemical matrix in the samples. Deviations from standard procedures were documented in the raw data files for these measirements. This project has involved the cooperation and participation of groups from all sections of the Analytical Chemistry Division (ACD) at ORNL. The organization, sample preparation, sample distribution, and many analyses were performed by the Inorganic and Physical Analysis (IPA) Group. An example of a sample flow diagram is shown in Fig. B.1.

All of the waste tank solutions analyzed for this project had a high dissolved solid content and high ionic strength. The high ionic strength has a significant effect on both the solution chemistry and various chemical measurements. For example, a potentionetric pH measurement is not based upon the hydronium ion concentration but is a function of the hydronium ion activity, which can vary significantly at high ion strength. The pH measurements on the waste samples discussed in this report ean only be considered as apparent $\mathrm{pH}$ values. In addition, the ionic strength affects the kinetics of reactions involving ionic species and can shilt the solubility behavior of many species. In general, the waste tank solution chemistry is far from ideal, and expected behavior for many species may not be observed.

The complex chemical composition of the waste tank samples is compounded by the effects of radiolysis. ${ }^{4}$ Within the liquid and sludge phases, the sample matrix experienced very high dose rates due to the intimate contact of the radioactive species. A majority of the radiation effects on the matrix is due to the alpha activity, which is primarily present in the sludge phase. The alpha radiation can result in decomposition of water to generate hydrogen peroxide and interactions with solute molecules to generate free radicals. The free radicals can interact with "ther solute species, including initiating the polymerization of organic materials.

The formation of the sludge phase is due to the insolubility of many st the species present at high $\mathrm{pH}$. A list of solubility products for many of the species of aterest is included in Table B.1 for the convenience of the reader.

Several miscellaneous deviations, not discussed under procedures, involve the initial handling of samples. Frequently the analytical methodology, as written by the U. S. Environmental Protection Agency (EPA) for regulatory measurements, was not appropriate for characterizing the contents of radio.etive waste tanks. It was then necessary to modify the regulatory procedures to (i) reduce radiation exposure io personnet to unect the policy of anaintaining radiation exposure As Low As Reasonably Achicvable (ALARA), (2) accomonodate the 


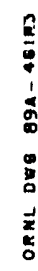
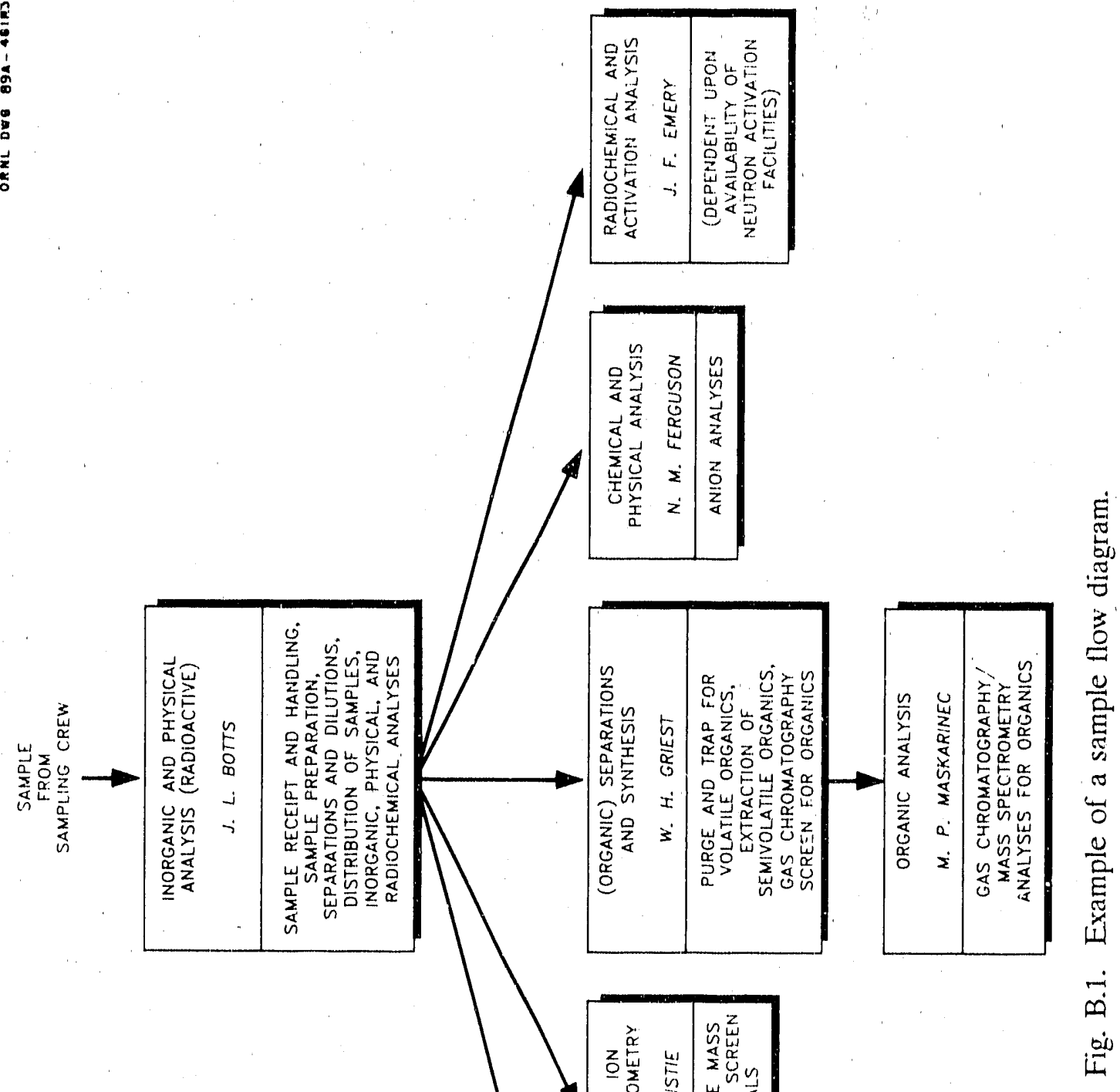
Table B.1. Solubility products for RCRA metals and T'RU metals

\begin{tabular}{|c|c|c|c|c|c|}
\hline Compound & Formula & $\mathrm{pK}_{\mathrm{ap}}{ }^{\mathrm{a}}$ & Compound & Formula & $p K_{y p}{ }^{a}$ \\
\hline RCRA Metah & & & $\begin{array}{l}\text { Silver cartontate } \\
\text { Silver chloride }\end{array}$ & $\begin{array}{l}\mathrm{Ag}_{2} \mathrm{CO}_{3} \\
\mathrm{AgCl} \mathrm{C}\end{array}$ & $\begin{array}{r}11.09 \\
0.75\end{array}$ \\
\hline Barium cartonale & $\mathrm{BaCO}_{3}$ & 8.29 & Silver chromate & $\mathrm{Ag}_{2} \mathrm{CrO}_{4}$ & 11.95 \\
\hline Barium chromate. & $\mathrm{BaCrO}_{4}$ & 9.93 & Silver hydroxide & $\mathrm{AgOH}$ & 7.71 \\
\hline Barium fluoride & $\mathrm{BaF}_{2}$ & 5.98 & Silver phosphate & $\mathrm{Ag}_{3} \mathrm{PO}_{4}$ & 15.84 \\
\hline Barium hỵdroxide & $\mathrm{Ba}(\stackrel{\mathrm{OH}}{\mathrm{O}})_{2}$ & 230 & Silver sulfate & $\mathrm{Ag}_{2} \mathrm{SO}_{4}^{4}$ & 4.84 \\
\hline Bariulu hydrogen phosphate & $\mathrm{BaHPO}_{4}$ & 6.50 & Silver sulfide (alpha) & $\mathrm{Ag} 2 \mathrm{~S}$ & 49.18 \\
\hline Barium phosphate & $\mathrm{Ba}_{3}\left(\mathrm{PO}_{4}\right)_{2}$ & 22.47 & Silvet sulfide (bela) & $\mathrm{Ag}_{2} \mathrm{~S}$ & 49,00 \\
\hline Barium nitrate & $\mathrm{Ba}\left(\mathrm{NO}_{3}\right)_{2}$ & 235 & & & \\
\hline Barium sulfate & $\mathrm{BaSO}_{4}$ & 9.96 & Thallium(l) chloride & $\Pi \mathrm{Cl}$ & 3.76 \\
\hline & & & Thallium(I) chromate & $\mathrm{Tl}_{2} \mathrm{CrO}_{4}$ & $12 .(0)$ \\
\hline Cadmium carbonate & $\mathrm{CdCO}_{3}$ & 11.28 & Thallium(I) sulfide & $\mathrm{Il}_{2} \mathrm{~S}$ & 20.30 \\
\hline Cadmium fluoride & $\mathrm{CdF}_{2}$ & 2.19 & Thallium(III) hydroxide & $\mathrm{Tl}(\mathrm{OH})_{3}$ & 45.20 \\
\hline Cadmium hydroxide & $\mathrm{Cd}(\mathrm{OH})_{2}$ & 13.60 & & & \\
\hline Cadrifum phosphate & $\mathrm{Cd}_{3}\left(\mathrm{PO}_{4}\right)_{2}$ & 3260 & \multicolumn{3}{|c|}{ TKU and Otber Hements of Interest } \\
\hline \multirow[t]{2}{*}{ Cadnium sulfide } & $\operatorname{CdS}$ & 26.10 & & & \\
\hline & & & Americlum(III) hydroxide & $\operatorname{Am}(\mathrm{OH})_{3}$ & 19.57 \\
\hline Chromium(III) fluoride & $\mathrm{CrH}_{3}$ & 10.18 & Americium (IV) hydroxide & $\mathrm{Am}(\mathrm{OHI})_{4}$ & 56.00 \\
\hline Chromium(II) hydroxide & $\mathrm{Cr}(\mathrm{OHI})_{2}$ & 15.70 & & & \\
\hline Chromium(III) hydroxide & $\operatorname{Cr}(\mathrm{O}) 1)_{3}$ & 30.20 & Calcium cartonate" & $\mathrm{CaCO}_{3}$ & 8.03 \\
\hline Chromium(III) phosphate (green) & $\mathrm{CrPO}_{4}-4 \mathrm{H}_{2} \mathrm{O}$ & 2262 & Calcium hydroxide & $\mathrm{Ca}(\mathrm{OH})_{2}$ & 5.10 \\
\hline \multirow[t]{2}{*}{ Chromium(11I) phosphate (violet) } & $\mathrm{CrPO}_{4}^{4}-4 \mathrm{H}_{2}^{2} \mathrm{O}$ & 17,00 & & & \\
\hline & & & Europium hydroxide & $\mathrm{Eu}(\mathrm{OH})_{3}$ & 23.05 \\
\hline Lead carbonate & $\mathrm{PbCO}_{3}$ & 13.13 & & & \\
\hline Lead chromate & $\mathrm{PhCOO}_{4}$ & 12.55 & Magnesium carbonate & $\mathrm{MgCO}_{3}$ & 4.40 \\
\hline lead chloride & $\mathrm{PbCl}_{2}{ }^{\mathrm{a}}$ & 4.79 & Magnesium hydroxide ${ }^{b}$ & $\mathrm{Mg}(\mathrm{OH})_{2}$ & 1092 \\
\hline Lead flusrode & $\mathrm{PhP}_{2}^{2}$ & 7.57 & & & \\
\hline Leot rhloride fluoride & Pbcils: & 8.62 & Neptunyl hydroxide & $\mathrm{NpO}_{2}(\mathrm{OH})_{2}$ & 21.60 \\
\hline lead hydroxide & $\mathrm{Pb}(\mathrm{OH})_{2}$ & 14.93 & & & \\
\hline Lead(IV) hydroxide & $\mathrm{Pb}(\mathrm{OH})_{4}$ & 65.50 & Plutonium(III) hydroxide & $\mathrm{Pu}(\mathrm{OIX})_{3}$ & 19.70 \\
\hline Lead hydroxide chloride & $\mathrm{PHOHCl}$ & 13,70 & Plutonium(IV) hydroxide & $\mathrm{Pu}(\mathrm{OH})_{4}$ & 55.00 \\
\hline Lead hydroxide nitrate & $\mathrm{PtOHNO}_{3}$ & 3.55 & Plutonyl(IV) hydroxide & $\mathrm{PuO}_{2}(\mathrm{OII})_{2}$ & 24.70 \\
\hline Lead hydrogen phosphate & $\mathrm{PbHPO}_{4}$ & 6.24 & Plutonium hydrogen phosphate & $\mathrm{Hu}\left(\mathrm{HPO}_{4}\right)_{2}$ & 27.70 \\
\hline lead phosphate & $\mathrm{Pb}_{3}\left(\mathrm{PO}_{4}^{4}\right)_{2}$ & 42.10 & & & \\
\hline Lend sulfale & $\mathrm{PbSO}_{4}$ & 7.79 & Scandium fuoride & $\mathrm{Scl}_{3}$ & 17.37 \\
\hline lead sulfide & $\mathrm{PbS}$ & 27.90 & Scandium hydroxide & $\mathrm{Sc}(\mathrm{OH})_{3}$ & 30.10 \\
\hline MAercury(l) cartionate & $\mathrm{Hg}_{2} \mathrm{CO}_{3}$ & 16.05 & Strontium cartonale & $\mathrm{SrCO}_{3}$ & 9.5 \\
\hline Anecury(I) chloride & $\mathrm{Hg}_{2} \mathrm{Cl}_{2}$ & 17.88 & Strontiun chromale & $\operatorname{SrCr()_{4}}$ & 4.65 \\
\hline Mercury(I) chromale & $\mathrm{Hg}_{2} \mathrm{CrO}_{4}$ & 8.70 & Strontium fluoride & $\mathrm{SrF}_{2}$ & 8.61 \\
\hline Mercury(1) hydroxide & $\mathrm{Hg}_{2}(\mathrm{OH})_{2}$ & 23.70 & Stronliuan phosphate & $\operatorname{Sr}_{3}\left(\mathrm{PO}_{4}\right)_{2}$ & 27.39 \\
\hline Mercury(II) hydroxide & $\left.\mathrm{Hg}_{\mathrm{g}} \mathrm{OH}\right)_{2}$ & 25.52 & Strontium sulfate & $\mathrm{SrSO}_{4}$ & 6.49 \\
\hline Mercury(I) hydrogen phosphate & $\mathrm{Hg}_{2} \mathrm{I} \mathrm{PO}_{4}$ & 12.40 & & & \\
\hline Mercury(I) sulfide & $\mathrm{Hg}_{2} \mathrm{~S}$ & 47.00 & Thorium hydroxide & $\mathrm{Th}(\mathrm{OH})_{4}$ & 44.40 \\
\hline Mercury(Il) sulfide (black) & $\mathrm{HgS}$ & 51.80 & Thorium phosphate & $\mathrm{Th}_{3}\left(\mathrm{PO}_{4}\right)_{4}$ & 78,60 \\
\hline Mercury(II) sulfide (red) & $\mathrm{HgS}$ & 52.40 & Thorium hydrogen phosphate & $\operatorname{Th}\left(1 \mathrm{IPO}_{4}\right)_{2}$ & 20.00 \\
\hline Nickel(II) cartonate & $\mathrm{NiCO}_{3}$ & 8.18 & Uranyl carbonate & $\mathrm{UO}_{2} \mathrm{CO}_{3}$ & 11.73 \\
\hline Nickel(II) bydroxide & $\mathrm{Ni}(\mathrm{OH})_{2}$ & 14.70 & Uranyl hydroxide & $\mathrm{UO}_{2}(\mathrm{OH})_{2}$ & 21.95 \\
\hline Nickel(1I) phosphate & $\mathrm{Ni}_{3}\left(\mathrm{PO}_{4}\right)_{2}$ & 30.30 & Uranyl phisphate & $\left(\mathrm{UO}_{2}\right)_{3}\left(\mathrm{POO}_{4}\right)_{2}$ & 46.70 \\
\hline Nickel(II', sulfide (alpha) & $\mathrm{NiS}$ & 18.50 & Uranyl hydrogen phosphate & $\mathrm{UO}_{2} \mathrm{HPO}_{4}$ & 10.67 \\
\hline Nickel(II) sulfide (beta) & $\mathrm{NiS}$ & 24.00 & & & \\
\hline \multirow[t]{2}{*}{ Nickel(11) sulfide (gamma) } & $\mathrm{NiS}$ & 25.70 & Y'trium fluoride & $Y^{\prime} F_{3}$ & 12.14 \\
\hline & & & Yutrium hydroxide & $Y^{\prime}(\mathrm{OH})_{3}$ & 22.10 \\
\hline
\end{tabular}

"Solubility product dala taken from Lange's Handboak of Chemistry, 12th Ed., edited by J. A. Dean. McGraw.Hill Hexolk (o). (1979)

${ }^{b}$ W. B. Meldrum and A. F. Daggell, A Texthxok of Qualitative Analysis, American Beok Conprany, p. 136, (1946). 
limitations of the instrumentation and facilities available, and (3) handle the complex nature of the sample composition (e.g. high levels of salt, dissolved solids, uranium, and thorium) to obtain valid data. To reduce radiation exposure, sample-size requirements were reduced significantly for numerous measurements. The reduced sample sizes and instrumental limitations resulted in redued sensitivities and other conflicts with some of the regulatory quality assurance/quality control (QA/QC) procedures that were too stringent to iceommodate these problems. The deviations from regulatory QA/QC practices will be discussed for individual procedures under the topic of Analytical Methods.

First, the EPA sample-preservation procedures that involve maintenance of samples at $4^{\circ} \mathrm{C}$ were avoided because of the lack of refrigeration facilitios for radioactive samples and to prevent shifts in the equilibrium states of solutions with elevated levels of both $\mathrm{pH}$ and dissolved solids. In addition, the on-site filtration, upon collection, and the on-site acid preservation of metals in aqueous samples were not performed because of the danger of handling radioactive materials. The EPA requirement, which states that all samples must initially be run undiluted, was not met for samples with high radiation levels or for techniques in which high-salt content interlered with the measurement. 


\section{B.2 INITIAL SAMPLING HANDLING}

The request numbers and the ACD numbers for all samples from this project are summarized in Table B.2. This information is useful for retrieval of data from the ACD data management system.

The waste samples were inspected by a health physics representative, and a field survey was performed on each sample before it was packaged and delivered to the High Radiation Level Analytical Laboratory (HRLAL). Based upon the field survey, all liquid samples exeept those from tank W-26 were handled in radiochemical laboratories (classified as radiation contamination zones). The sludge samples required remote handling for dissolution and dilution before their removal from the hot cell and distribution to various laboratories. The liquid samples from tank W-26 also required remote handling in the hot cell with subsamples removed for analysis. Sample volumes or weights were adjusted to comply with Appendix 7 of the ORNL Health Physics Manual.

\section{B.2.1 Liquid Samples}

Liquid samples, designated with " $L$ " in the sample identification number, were decanted into 250)-mL glass "I-CHEM" jars at the sampling point. Some minor leakage problems were experienced with these jars. The jars, which had previously been cleaned aceording to EPA protocol, were labeled and capped using lids with Tellon scals. Each jar was enclosed in a plastic bag and shielded in a lead pig before delivery to Building 2026. Dose rates on contact with full jars were on the order of a few hundred $\mathrm{mR} / \mathrm{h}$, except the "W26-L" code samples where the dose rate was about $1.2 \mathrm{R} / \mathrm{h}$. The sample liquids all appeared to be single-phase and ranged from pale to deep yellow with little, if any, turbidity. Upon delivery, liquid samples were phoiographed in plastic bags on the benchtop using ambient light, returned to their lead pigs, then secured in the sample storage room.

\section{B.2.2 Sludge Samples}

Each sludge sample was delivered to Building 2026 contained in its original sampler and sealed in two 6-mil plastic slecves. The completed package was delivered in a metal can inside a stainless steel (SS) carrier. Samplers were placed in a hot eell on arrival, then removed from the SS carricr and inner can. The samples were allowed to siand overnight in the PVC samplers to allow the solids to settle. The heights of the sludge (solids) and liquid layers were then measured. Each sludge sample was transferred to one or more "I-CHEM" jars wilhin about three days of sampling except request IPA6282, which was transferred after seven days. After the sludges were transferred to I-CHEM jars, they were photographed through the cell window. The resulting pictures had poor resolution, and a strong yellow cast from light filtered through the zine bromide-filled window. Sluciges were designated either as "-H" (hard sludge) or "-S" (soft sludge); this designation was made at the sampling point and refers to the type of sampler used to collect the sludge.

The dimensional characteristics of the sludge samples as received are listed in Table B.3. The original sampling plan called for removal of the liquid layer before a transfer of sludge to its receiving jar. All tanks except W-28 contained thick sludge blankets that required more than one sampler to obtain a full vertical core. These sludges were to be divided in the hot eell 
'lable 13.2. ACD Sample Codes (Request Number / Sample Corde')

\begin{tabular}{|c|c|c|c|}
\hline Stumple & $11 A(2026)$ & $C P \wedge(4 S O N) S)$ & IAI. $(7920)$ \\
\hline W21-1,1 & $\operatorname{IPA}(3279 \times 200130-092$ & & \\
\hline$W 21-12$ & $11 / 10279 \times 900130.093$ & C'A10585/900307.075 & 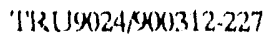 \\
\hline$W 21-1.3$ & 1)/ $19279 / 9(9) 130-094$ & & \\
\hline W23-L1 & (HAG & CPA10585/K00307-076 & 'I'RU(X)24/(x) 312.228 \\
\hline$W 24-1.1$ & TPA6222/890925166 & & \\
\hline$W 24-1.2$ & 11 A $6222 / 890925-167$ & CPA10231/891121-047 & 'I'RU8742/R9I023-()2I \\
\hline$W 24 \cdot 1,3$ & IPA6222/810925-168 & & \\
\hline W25-1,1 & IPA6222/890925-169 & & \\
\hline$W 25-1.2$ & $\left.I^{\prime} \wedge 6222 / 89\right) 925-170$ & CPA10231/891121-048 & 'I'RU8742/891023-(122 \\
\hline$W 25-1.3$ & $\operatorname{IP} \wedge 6222 / 8 \% 09254171$ & & \\
\hline W26-1 1 & IPA6222/890925-197 & & \\
\hline$W 26-1,2$ & $1 P \wedge 6222 / 8(\mathcal{Y}) 92.5 .198$ & CPA10231/891121-049 & 'I'RU8742/X91(123.023 \\
\hline$W 26.1 .3$ & $I P \wedge 6222 / 890925.199$ & & \\
\hline W27-1.1 & IPA6222/890925.172 & & \\
\hline W27.1.2 & $1 P \wedge 6222 / 890925.173$ & CPA10231/891121-050 & $\operatorname{ITR}(187428991023-124$ \\
\hline W27.1.3 & $11^{\prime} A 6222 / 89(1) 25.1 \% 4$ & & \\
\hline W28-1.1 & IPA6222/890925-175 & & \\
\hline$W 28 \cdot 12$ & $11 \times 16222 / 890925-176$ & $C P A 10231 / 891121-051$ & TRR J8742891023.025 \\
\hline$W 28 \cdot 1.3$ & $I 1 \times 6222 / 890925-174$ & & \\
\hline W31-1.1 & $\operatorname{IPA} 6222 / 8(3) 925-178$ & & \\
\hline$W 31 \cdot L 2$ & IPA6222/890925-179 & CPA10231/891121-052 & 'I'RU 87428891023-(126 \\
\hline$W 31-1.3$ & IPA6222/890925-180 & & \\
\hline W29.1.1 & $1 P \wedge 6255 / 891204-048$ & $C P A 10367 / 900110-012$ & 'I'R U $88875 \times(0) 1(02-1) 56$ \\
\hline$w 29-1.2$ & IP $\triangle 6255 / 891204-049$ & CPA10367/900110-013 & 'TRRU J8875/(9)(X)1(02-057 \\
\hline W29.1.4 & IPA6255/891204-050 & CPA10367/900110-014 & 'I'RU $88875 / 900102-058$ \\
\hline W30-I.1 & IPA6255/891204-(051 & CPA10367/M(M)110-015 & 'TRU J8875/MOO102.059) \\
\hline$w 30 \cdot 1.2$ & IPA6255/891204-0.52 & CPA10367KM(X)110-016 & 'I'RU $88 \times 75 / . \times 0(0) 102-(x)$ \\
\hline W30-1.4 & IPA6255/891204-(053 & CPA10.367/MOO0110-017 & TRR U.8875/900102-(x)] \\
\hline W21-S & $I P \wedge 6282 / 900131-107$ & & TRRU(U)23/X)(1)312-210 \\
\hline W23-S & IPA6282/\%OO131-108 & & 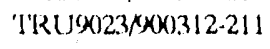 \\
\hline W24-S & IPA6223/890925-205 & & 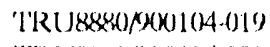 \\
\hline W25-S & $\operatorname{IP} \wedge 6223 / 890925-209$ & & 'TRUS880)(9001(04-020) \\
\hline W28-S & $I^{P} A 6223 / 8 \mathcal{M} 0925-217$ & & 'I'RU U888() (900)L(04-1)2L \\
\hline W31-S & IPA6229/8910099.019 & & 'I'RU U8880/M(K)I(04.022 \\
\hline $\mathrm{W} 31-\mathrm{H}$ & IPA6229/891009-(020 & & I'RU J88880/9001(04-023 \\
\hline W26-S & $\mathbb{I P} \wedge 6257 / 891205-0.51$ & & ITRU 18944/X(N)130)-168 \\
\hline W26S-1) & IPA6257/891205-051 & & 'IRU $8994(x)(x) 13(3)-169$ \\
\hline W27.111-S & $I P A 6257 / 891205.052$ & & 'I'R U \\
\hline$W 27 \cdot 111-11$ & IPA6257/891205-053 & & 'IRUU8944אX(X)t30-171 \\
\hline$W 27-111-11-1)$ & IP $\triangle 6257 / 891205-053$ & 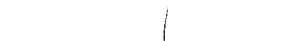 & 'I'RU J J9944/(x)1.3(3)-172 \\
\hline
\end{tabular}


13-11

I'able B.3. Dimerisional characteristics of sludgo sample

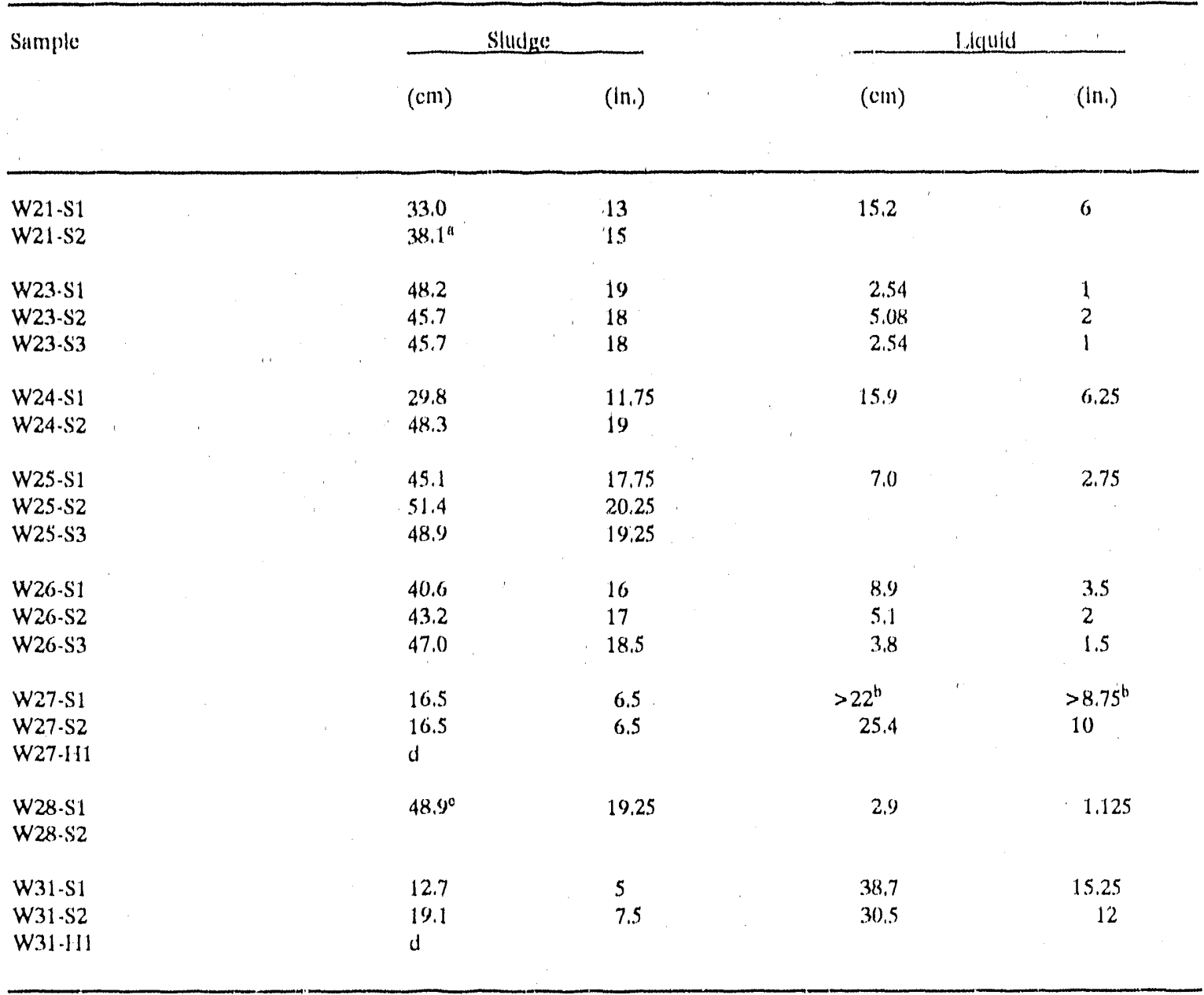

"Sample W21-S2 was taken with an older design sampler that collected a shorter core $(38.1 \mathrm{~cm})$ than the other samplers.

bestimated. Sampler W27-S1 leaked a small amount. Exact liquid height was not measured.

"Sampler' W28-S1 contained a full vertical core of the sludge in the tank.

${ }^{d}$ Could not measure the vertical core thickness with the hard sludge sampler. 
so that one-fourth of the solids from each related sampler were mixed logether and sonicated, Physical and chemical analysis would be pertormed on the sonicated composite sludge, and the remaining liquid and solids fractions would be reserved.

During the project, there were some variations in sludge handling procedures. The first batch of samples were transferred from sumplers to jars without removal of excess liquid, including sample W27-S1 and all solt sludges from tanks W24, W25, W28, and W31. All other sludge samples had excess liquid decanted before transler to jars. Funncls were used in transferring solt, fluid sludges, but denser, more viscous sludges were transferred directly to avoid sample loss.

Sludge sample W25-S2 was noticeably stratified, so it was split into two components using two jars- the lower layer was thick and brown with hard gritly particles, and the upper layer was soft and yellow.

Composite sludge samples were made up for each tank in proportions representative of the complete vertical core (see Table B.4). "Solt" sludges and "hard" sludges were analyzed separately. The first batch of samples were split without any mixing, but samples from the second batch were gently stirred with SS spatulas in their receiving jars before separating. All samples were recombined in representative proportions for inorganic and radiochemical analyses. Portions were taken from each jar using the spatula- each portion consisting of approximately $25 \%$ of the total from that jar.

Composite sludges were sonicated for about 1 min each to ensure complete mixing. Sonicated sludges appeared to be well-mixed, but often contained hard particles suspended in the body of sludge. No practical amount of mixing will completely homogenize these samples.

The W27-H1 sampler contained both liquid and hard sludge. Liquid was poured into one jar and the sludge was scraped out into another jar using a SS spatula. Since the hard sludge sampler was opaque, liquid and solids depths could not be measured. The hard fraction of W27-H1 was too stiff to sonicate.

Jar lids did not always seal properly, especially if any sludge got smeared on the jar lip. Sludge liquid would evaporate from poorly sealed jars, leaving a crust of dried salts between jar and lid. The W27-S1 sampler was leaky, and an indeterminate amount $(<13 \mathrm{~cm})$ of the licyuid was lost through seepage. 
Table B.4. Components of eomposite sludge samples

\begin{tabular}{ll}
$\begin{array}{l}\text { Composite } \\
\text { sumple }\end{array}$ & Constituents \\
\hline W21-S & W21-S1, W21-S2 \\
W23-S & W23-S1, W23-S2, W23-S3 \\
W24-S & W24-S1, W24-S2 \\
W25-S & W25-S1, W25-S2, W25-S3 \\
W26-S & W26-S1, W20 W26-S3 \\
W27-H1-S & W27-H1 soft : Jge \\
W27-H1-H & W27-H1 hard sludge \\
W28-S & W28-S1 \\
W31-S & W31-S1, W31-S2, W31-S3 \\
W31-H & W31-H1 \\
\hline
\end{tabular}

${ }^{a}$ Sample W27-H1-H contained no free liquid and was not sonicated. 


\section{B.3 ANALY'TICAL METHODOLOGY}

'The unalytical procedures are listed in Table B.S, which includes a bricl' summary for ench procedure and detection limits for most measurements. Additional discussion on selected procedures and techniques is provided to document deviations from procedures or problems encountered.

\section{B.4 INORGANIC AND PHYSICAL MEASUREMEN'IS}

\section{B.4.1 Sample Preparation for Mctal Analysis}

Liquid samples were prepared by a $5.0 \mathrm{~mL} / 50.0 \mathrm{~mL}$ dilution with $5 \%$ nitric acid. A 0.5 - $\mathrm{mL}$. aliquot of a $1.0 \mathrm{mg} / \mathrm{mL}$ scandium standard was added prior to dilution to serve as an internal standard for Inductively-Coupled Plasma (ICP) analyses.

Sludge samples were preparod by microwave digestion with a CEM MDS.81D microwave instrument. The digestion procedure is similar to the proposed SW-846 Method 3(151, Microwave Assisted Acid Digestion of Sediments, Sludges, Soils, and Oils. Approximulcly 1.() g of sludge sample was placed in a Tellon vessel $(120 \mathrm{~mL}$ size) with $10 \mathrm{~mL}$ of nitric acid. After heating for 2.5 min al $100 \%$ power and $10 \mathrm{~min}$ at $80 \%$ power, the sample was allowed to cool to room temperature. After cooling, $2-5 \mathrm{~mL}$ of $30 \%$ hydrogen peroxide was added dropwise to the solution. On the completion of efferveseence, the samples were liftered through a \#541 Whatman lilter and diluted to $100 \mathrm{~mL}$ with ASTM Type II watcr. A 1.0 $\mathrm{mL}$ aliquot of a $1.0 \mathrm{mg} / \mathrm{mL}$ scandiun standard was added prior to the ditution. The scandium serves as an internal standard to account for matrix interferenees with ICP analyses.

\section{B.4.2 Sludge Density}

The densitics of the wet sludges (including the interstitial liguid) were measured using graduated 15- mL centrifuge tubes. Portions of sludge were packed into thin Teflon tubing, then extruded from the tubing into the bottoms of tared centrifuge tubes using a glass stirring rod as a plunger. Care was laken not to smear sludge on the inside wall of the ecritriluge tubes. Samples were capped and centrifuged at high speed $(>4000) \mathrm{G}$ ) for $15 \mathrm{~min}$ to displace any air, then total (both liquid and solids) and compacted solids volumes were recorded and the loaded lubes were reweighed. Densities were eomputed as net mass/total volume.

Sample W27-H1 was dry and contained lumps and fines. A modilication of the above technique was used to delermine this sample's density. $1 .(0) \mathrm{mL}$ of liquid from the same tank (liquid sample W27-L.3) was placed in a centriluge tube and weighed. The solid sludge wiss added to the liquid and centrifuged to compact the solids and displace any air. Sludge volume was computed as the diflerence between liquid volume and total volume after centriftigation, and sludge mass was computed as the differenee between total mass and the mass of tube plus liquid. Densily was computed as net mass/net volume. 


\section{1 .5}

'linble 13.5. Antalylical melhods

\begin{tabular}{|c|c|}
\hline Pruramoles & Roforence \\
\hline \multicolumn{2}{|c|}{ Radiochernical Proxodure } \\
\hline Gross alpha & $\begin{array}{l}\text { ACD 9 } 0(2301, \\
\text { BPA.600.90010 } \\
\text { ACD } 90733005\end{array}$ \\
\hline
\end{tabular}

Ciross bela

ACI) $90733(00) 5$

ACD 9002302

Ciamma

ACD 221096

Spectroscopy

ACD 200376

EPA. $600 \cdot 901.1$

Alphthu

ACD 22109

speciroscopy

(Americlum.241

ACD 100,3115

Curlum-244

Uranlum-232,-233, $-235,-238$

Plutonium-238, $-239,-240$ )

Sirontlum.90

EPA-600.S(X)5.0

ACD 221807

I'rillum

ACD 20950

Carlon-14

Technetium-99

ACD 511873

Iexdine-129

ACD 221393
Sample is dissolved, if necessary, then sumples are dill. uled, if needed, to reduco dlssolved sollds; if small volume of sample (usually $0.1 \mathrm{ml}$ ) is ovaporated on 11 stulnless slecel planchet that is alphit counted with a gas-flow proportional counler in $2 \cdot \mathrm{pl}$ geometly.

Sample is dissolved, if necessary, then samples me dill. uled, If needed, Io redice dissolved sollds; a small volume of sample (usually $0.1 \mathrm{~mL}$ ) is evaporaled on a slatiless slect planchet that is beta counted with a gas-flow proportionul counter.

Sannple is dissolved, if necessinty, and a 10-ml. alliguen is analyaed by gamma spectrosecopy. If the dend lime excededs $5 \%$, the sample lis dlluted or mounled in a less efficlent geomotry and re-analyaced.

Sample is dissolved, if necessary, colpreciplenled wlth ferric hydroxlde to separate acilnides from complex malrixi a small volume of ample is then evaporated on a sininless stcel plate that is counted with a surface barrlor detector.

Sample is dissolved, if necessary; strontium catrier is added, and the sample is processed through several puri. fication steps; final puriflcation is made by preciplatilon of the strontium as the carbonate. The preclpltate la mounte ed for trela counilng with a gas-flow proportional counter.

Tritium is distilled from açueous samples and a perrion of the distillate is analyzed by liquid scintllation counting.

Samples were healed to 900$)^{\circ} \mathrm{C}$ (o volat lize organle species and decompose carbonates. Organics were converted to $\mathrm{CO}_{2}$ In an oxlalizing bed. Off-gases were collected in a basic solution and counted by llquid scintlliation.

Technellum is first separated from other fisslon products by an oxidation step followed by extractlon of the pertechnelate anion. The "9a' I'c is then stripped Into water and loaded onto an anlon exchange resin. The "xhl'c content is determined by neutron activation analysis of the resin column.

lodine actlvity is separated from olher flssion products by oxidation to periedate with sodlum hypochlorlte in basic solution, followed by reduction to lodine whith hydroxylamine hydrochloride and extraction of lodlene Into carbon tetrachloride. The locline is stripped Into an aqueous solution of potasslum metabisulfate which reduces the iodine to lodicte.
Appreximate Detectlonl 1. InIlt

$2 \mu(1 / 1$

4 p. $1 / 1$

varles with encrgy

50 p. $(1 / 1 \mathrm{ml}$

$4 \mathrm{pc} . \mathrm{l} / \mathrm{I}$

$s p(: 1 / \mathrm{ml}$.

$5 p(\mathrm{p} / \mathrm{ml} \mathrm{l}$ 


\section{Inorumuic: Amulytleal Proxxodurex}

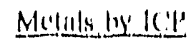

IitA $2(x) .71$

$S W \cdot-4+4(1 \cdot-60) 10$

\begin{tabular}{|c|c|}
\hline silver & $(\Lambda g)$ \\
\hline Arsenk: & $(\Lambda s)$ \\
\hline Martum & (13:1) \\
\hline Cralmium & $(C, d)$ \\
\hline Chromilum & $(c r)$ \\
\hline Nickel & (Ni) \\
\hline l.end & (l'b) \\
\hline Sictenitum & (Se) \\
\hline I'halllu|II & (II) \\
\hline \multirow[t]{2}{*}{ Aluminilum } & $(A I)$ \\
\hline & $(\mathrm{NI})$ \\
\hline \multirow[t]{2}{*}{ H(r) } & (B) \\
\hline & (B) \\
\hline C'nlcium & (C'il) \\
\hline Cobill & $(C)$ \\
\hline $\mid r(u||$ & (lie) \\
\hline P'ulassilumu & (K) \\
\hline Magnesilum & $(\mathrm{Mg})$ \\
\hline Sinflium & (Nii) \\
\hline \multirow[t]{2}{*}{ Silroullium } & (Sir) \\
\hline & (Sr) \\
\hline I'horiul & (Ihi) \\
\hline |maniumu & (1) \\
\hline zime: & $(/ 111)$ \\
\hline
\end{tabular}

Mutinls by ciliss

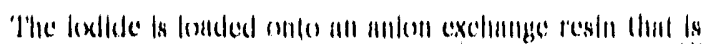

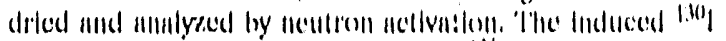

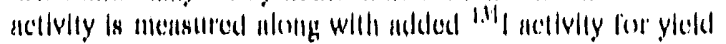
corresilonis,

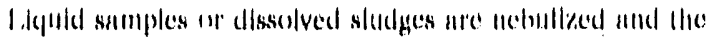

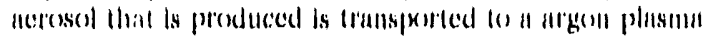

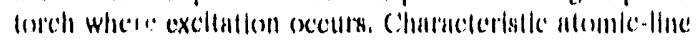
spectra are prexlueced by an incluctively conpled plinsma (IC.P); the intensily of the emission lines from the exciled elenents

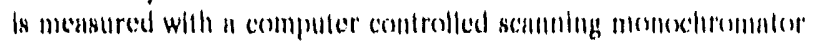

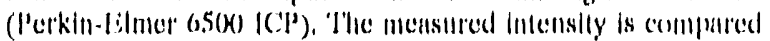
lo stored calibralion curves for quantitution.

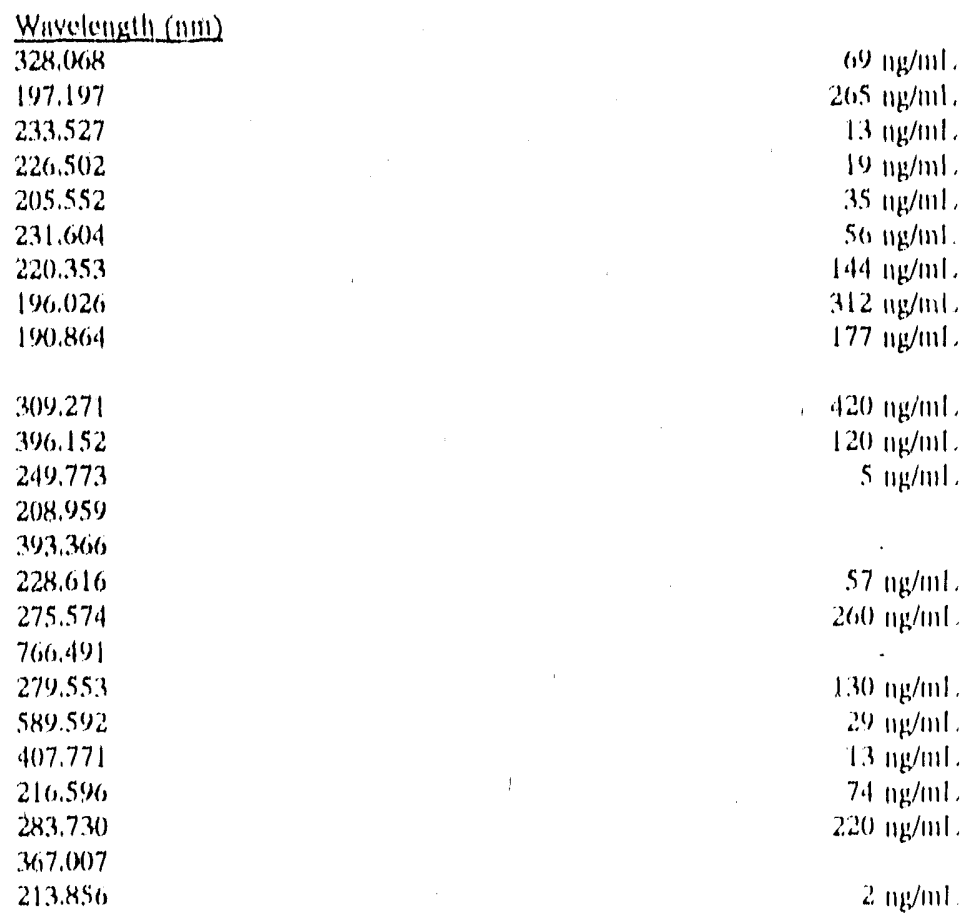

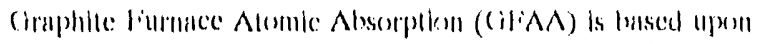

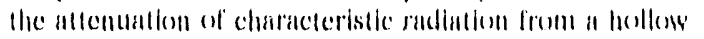

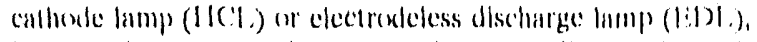

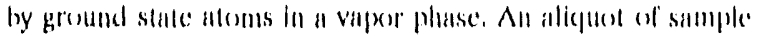

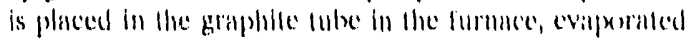
wn dryness, char red, and alomized. A momechromator and a

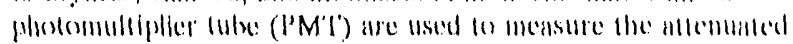

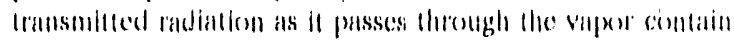

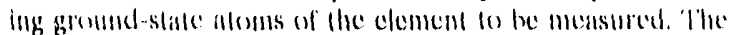

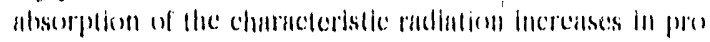

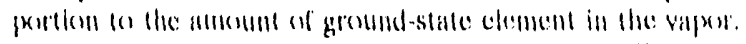
The: measured absorplion is compared lo stored callibration curves for cymanthallon. 
'l'nble 13.5, comilinined

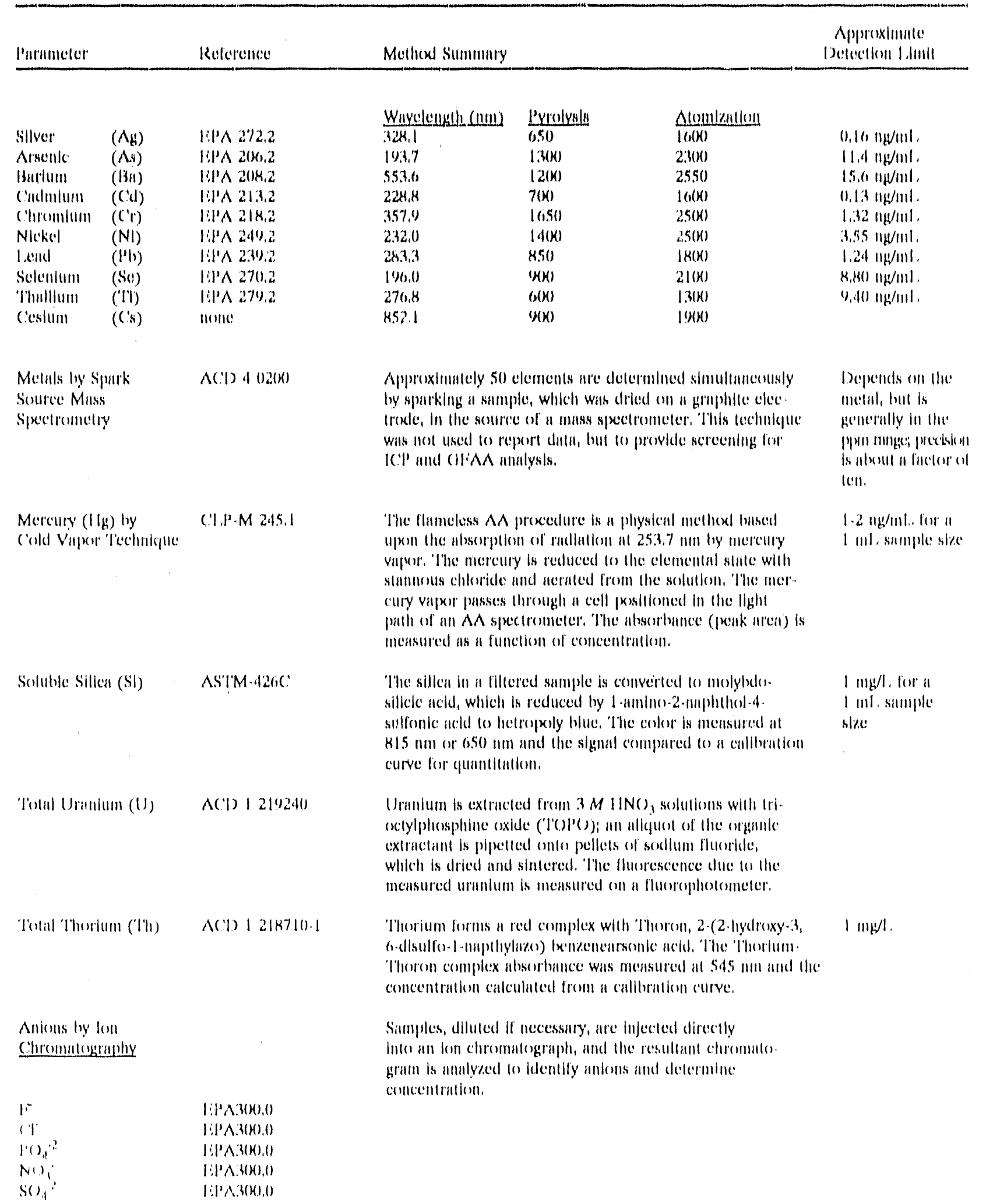


'l'uble 13.5, connllnued

\begin{tabular}{|c|c|c|c|}
\hline Parmincler & Relorence: & Mothexd Summunty & 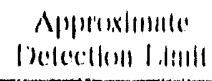 \\
\hline pll & $\begin{array}{l}A(D) 12: 3(x) 41 \\
S W \cdot S 4(6.1)(x) 40\end{array}$ & 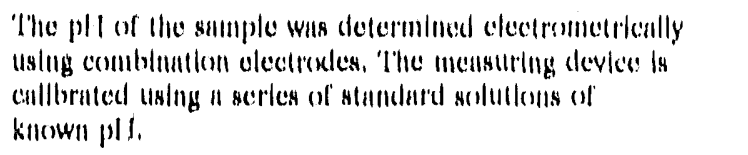 & $\|\omega\|\|\eta\|\|(n \|)\|$ \\
\hline 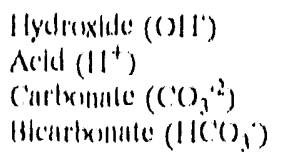 & $A(D) \mid 0013105$ & 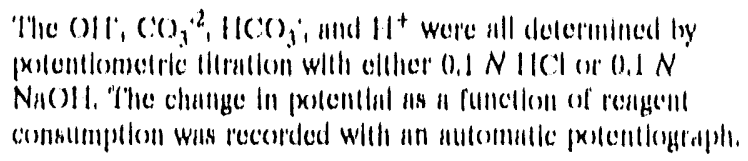 & $(0,1) 1 \mathrm{~N}$ \\
\hline (ymmlde $\left(C N^{\prime}\right)$ & $S W \cdot 844(1.9) 10$ & 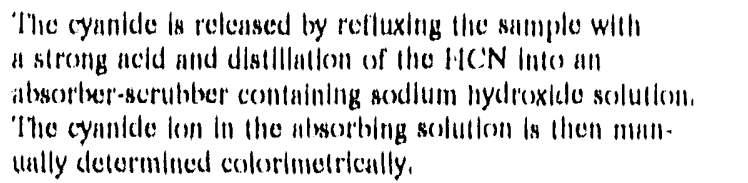 & 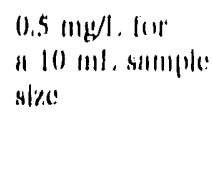 \\
\hline Sulfide $\left(S^{\prime \prime 2}\right)$ & SW- $84(1.9) 30$ & 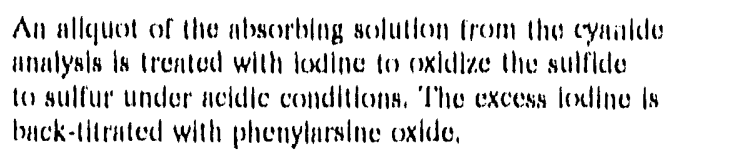 & $\begin{array}{l}2 \mathrm{mg} / \mathrm{l} \text {. for } \\
\text { a } 10 \mathrm{mI} \text {, sillmple } \\
\text { slat: }\end{array}$ \\
\hline 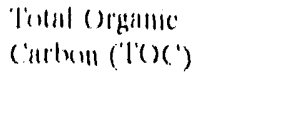 & $S W \cdot 8+46 \cdot 10060$ & 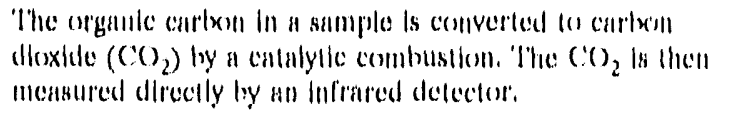 & \\
\hline follal carlond (l'(') & & Sece 1 ext, Sect, 13,4,4. & \\
\hline Imerganife ('arloull (IC') & & sece text, secel, 13,4,4. & \\
\hline \multicolumn{4}{|c|}{ Plinsical Mesisurement Proxexlurex } \\
\hline Thulal Solids & $\operatorname{l} P^{\prime} \wedge \cdot 6(0) / 6(6) . .3$ & 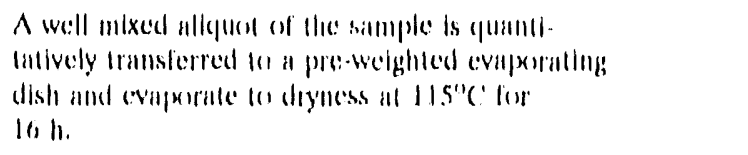 & $10 \mathrm{~m} / \mathrm{h} / \mathrm{I}$ \\
\hline 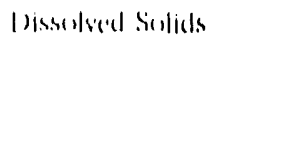 & $\ln \wedge \cdot 6(x) / 6(0) 2$ & 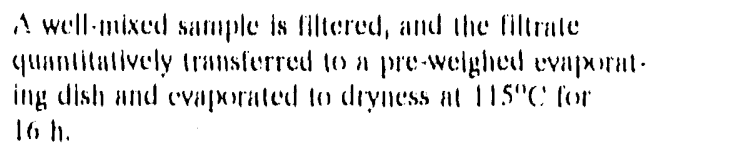 & $4 \mathrm{mg} / \mathrm{l}$. \\
\hline Susprended sollids & $1: 1 \times \theta(x) / 10(1) .2$ & 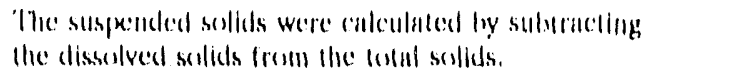 & $4 m g / 1$ \\
\hline In'msily (licguids) & $A(') 111111$ & $\begin{array}{l}\text { A mesasured volume of sample is weighed it annblent } \\
\text { lemperalure. }\end{array}$ & \\
\hline |xensly (sludgen & & See text, Secl, 4.4.2 & \\
\hline
\end{tabular}




\section{B.4.3 Common Anions}

The determination of anions was primarily for developing process flow sheets, but the anion data were also useful in understanding the distribution of various metals between the liquid and solid phases. Liquid samples were analyzed by ion chromalography (Dioncx, Model 16 instrument) for nitrate, chloride, fluoride, sulfate, and phosphate. Because of the high nitrate concentration, it was necessary to dilute the samples so that the nitrate peak would not overlap the other peaks. This resulted in some loss of sensitivity relative to the original solution. The detection limits for these high nitrate samples were $5,000 \mathrm{ppm}$ for sulfate and phosphate, and $50(0) \mathrm{ppm}$ for lluoride. Hydroxide, carbonate, and bicarbonate (if present) were determined by potentiometric titration.

A basic limitation of ion chromatography is that the relative concentration of all anions must be within a factor of about 100 , or the predominate species behaves as an eluant for the other anionic species, which results in all anions eluting in a single band. High levels of certain anions can be tolerated by the use of special precolumns to reduce the level of a predominate species, however; these precolumns were not available for this project. A new ion chromatograph is currently being installed for radioactive samples. Following some methods development work, much more detailed anion data should be obtainable for future waste-tank type samples.

The determination of anions within the sludge phase of the waste tanks is a problem area. Ion chromatography may not be appropriate for anion determinatic $n$ in sludge samples since the solid phase must first be placed into solution with a strong acid. The use of a strong acid to dissolve the sludge samples places severe limitations on the anions that can be determined by ion chromatography. Considerable development work may be required to obtain useful anion data for the sludge phase of the waste tanks.

\section{B.4.4 Carbon Analysis}

Liquids were assayed for total carbon (TC) and inorganic carbon (IC) on the Dohrmann DC90 carbon analyzer. The TC was measured by direct sample injection into a combustion tube packed with cobalt oxide at $900^{\circ} \mathrm{C}$. The furnace was continually sparged with oxygen, which converted all carbon to carbon dioxide and transported the off-gases through a detector chamber. The carbon dioxide was detected by a nondispersive infrared (IR) detector. Liquids were assayed for IC by sample injectic $n$ into a phosphoric acid bath that converted carbonates to carbon dioxide. The phosphoric acid bath was continually sparged with oxygen, which transported the evolved carbon dioxide to the IR detector.

An optional solids adapter for the Dohrmann DC-90) carbon analyzer was employed for the measurement of total carbon and total organic carbon (TOC) on the sludge samples. Sludges were assayed for TC by placing the sample in a platinum boat, then heating it $10900{ }^{\circ} \mathrm{C}$ to oxidize organic species and decompose carbonates. The furnace was continually sparged with oxygen, which passed through a combustion bed packed with cobalt oxide for conversion of carbon-bearing species to carbon dioxide. The evolved carbon dioxide was transported to the IR detector. Sludges were assayed for organic carbon after pretreatment with concentrated nitric acid. The sample was weighed, acidified, and dried before placement in the same furnace used for total carbon determination. 


\section{B.4.5 Cyanides}

Liquid samples from tanks W29 and W30 were analyzed for total cyanide using EPA method 9010 modified for small samples. Sample size was reduced from $5(X)$ to $10 \mathrm{~mL}$ in order to reduce the radiation hazard to the analyst and to conserve the limited sample. Trap solutions were reduced from 50 to $40 \mathrm{~mL}$, and the scrubber bottles were modified to maintain collection efficiency using smaller trap solution volumes. Volumes and concentrations of colorimetric reagents were adjusted so that final concentrations were the same as they would have been using the unmodified EPA procedure.

Although good results were obtained from an external control solution, no color developed in either spiked or unspiked samples. An additional $2 \mu \mathrm{g}$ of cyanide was added directly to a leftover trap solution from sample W29-LA and then reanalyzed; still no color was observed. The failure of color to develop in the sample with post-distillation spike added indicates that an interfering substance was distilled from the samples and absorbed in the trap solutions.

Two types of interference are possible. The interfering substance could destroy any cyanide present, or it could prevent color formation between cyanides and pyridine/barbituric acid. This question will be resolved using either an ion-selective electrode for cyanide or by ion chromatography.

\section{B.4.6 Metal Analysis by Inductively Coupled Plasma Atomic Emission Spectroscopy (ICP- AES)}

A Perkin-Elmer XR 6500 ICP was modified for use with radioactive samples by isolating the ICP torch box in a SS enclosure for containment of radioactivity. The enclosure is provided with sliding glass doors and ports that may be gloved if higher levels of radioactivity must be handled. The performance of the system with the separation of the torein box and monochromator was evaluated and found to be comparable with normal operation.

The Perkin-Elmer ICP, cmployed for the analysis of the tank samples, has a poor dynamic range relative to most other ICP systems. The poor dynamic range translates into a narrow calibration range, which resulted in numerous measurements excecding the high stanciard of the calibration curve. When a measurement exceeded the calibration range, several dilutions were usually required to obtain a valid result. The additional dilutions and sample handling resulted in a significant increase in the analysis time and radiation exposure to the analyst.

A Perkin-Elmer Cross-Flow, a Hildebrand Grid, and a Meinhard Type C nebulizer were evaluated for operation and effectiveness with samples containing high dissolved solids contes. while maintaining acceptable standard deviations. The Meinhard Type $\mathrm{C}$ nebulizer was chosen for measurements on the waste tank samples. This ncbulizer is similar to a standard glass concentric type, but has the inner capillary recessed from tip to improve performance with samples containing high solids. In addition, a mass flow controller was added to the nebulizer gas flow to improve the precision of the ICP measurements. 
Quality control (QC) was applied to batches of tank samples, where a batch was defined by grouping samples with similar matrices. All samples were analyzed with an internal standard (scandium) to compensate for matrix differences on the nebulization of the sample.

Batch acceptance criteria for the ICP measurements were based upon several factors. The percent relative difference (PRD) for the calibration check standard (CCS) was required to be within $\pm 20 \%$ of the known standard value. The PRD for duplicates and serial dilutions were required to be between $\pm 20 \%$ for analytes at 10 times the instrument detection limit (IDL), or higher. Spike recoveries were required to be within the range of $75-125 \%$. If an analyte spike recovery was outside this range, the analytical line employed was inspected graphically, and a hardcopy of the original sample data was saved. The PRD for an interference check standard was required to be within $\pm 25 \%$ of the known standard concentration. The relative errors for analytes at or near the IDL were not employed for batch acceptance. The calibration blank and reagent blanks were monitored to check for contamination of the reagent and/or the sample introduction system. It was up to the discretion of the analyst to determine if there was a problem with the blank measurements and take the necessary action for correction.

\section{B.4.7 Sample Preparation for Mercury Analysis}

In addition to inorganic forms of mercury, the EPA procedures suggest that organo-mercury compounds may be present which will not respond to the cold vapor technique unless they are first broken down to the mercuric ions. Due to biological activity this expectation is reasonable for environmental or sewage-type samples, but is questionable for the type of waste found in the storage tank samples. Based upon the operations and processes that are employed by the waste storage system, only elemental or inorganic mercury is likely to be present. As a result of the harsh environment (high $\mathrm{pH}$, high salt, and radioactivity), it is unlikely that sufficient biological activity is present in the waste storage tanks to convert inorganic mercury to organo-mercury compounds. Therefore, to reduce sample handling and radiation exposure to personnel, the sample digestion steps to oxidize organo-mercury compounds to mercuric ions was not used.

Hydrogen peroxide, which results from radiolytic decomposition of water ${ }^{4}$ in aqueous solutions, is probably present in the waste storage tanks. Hydrogen peroxide is a strong oxidizing agent in alkaline solutions that tends to stabilize the mercury in the high pH waste tanks. Potassium permanganate was used to evaluate the reducing power of the waste tank samples prior to mercury measurements. The samples were tested by observing the decolorization following the addition of several drops of $5 \%$ potassium permanganate. The sludge samples, which were prepared for ICP spectrochemical analysis (Sec. B.4.1), were employed for the mercury measurements. The liquid samples were diluted with $5 \%$ nitric acid prior to mercury analysis.

\section{B.4.8 Mercury Analysis by Cold Vapor Technique}

The instrumentation for the mercury cold vapor technique was a MHS-20) (Mercury-Hydride System) attachment for the Perkin-Elmer 5100 Atomic Absorption (AA) system. The MHS-20) includes a heated $10 \mathrm{~cm}$ quartz cell which is placed in the flame AA light path of the 51()() system, sample handling system, and a system controller for programing the addition on 
reductant and reaction times. The signal from the spectrometer is then processed by the $51(0)$ system computer and peak areas are employed for quantitation. A listing of the quality control data for merculy analyses is included in Table B.6.

\section{B.4.9 Metal Analyses by Graphite Furnace Alomic Absorption (GFAA)}

The instrumentation employed for the GFAA measurements was a Perkin-Elmer 5100 AA system with the HGA-600 furnace option with Zeeman-effect background correction. The spectrometer was placed in a SS enclosure, similar to the ICP system, to permit measurements on radioactive samples. The technique used for all GFAA samples was an approach referred to as the stabilized temperature platform furnace (STPF) ${ }^{5}$ concept, which was developed by Perkin-Elmer Corporation. The STPF approach is based on the use of the L'vov platform, fast electronics, quantitation by peak area, matrix modifiers, pyrolytically coated graphite tubes, fast heating of furnace, no flow of support gas during the atomization step, and Zeeman-effect background correction. Based on recent literature, an additional step was added to the typical furnace temperature program that consists of a cool-down step. ${ }^{6}$ It was reported that, in some instances, better results were obtained if the furnace was allowed to cool down to ambient temperature before the atomization step. Also reported was that, for some real samples, the use of a cool-down step reduced or completaly eliminated interferences that could not be controlled otherwise. Therefore, the furnace temperature program for all GFAA measurements included a cool-down step before atomization.

The analytical approach developed for GFAA measurements provided adequate QA/QC and followed the ALARA principle by minimizing the radiation exposure to the analyst. Instrument calibration consisted of constructing calibration curves from the average absorbance values, which were obtained with double injections of a blank and 3-4 standards, vs the known concentrations. The concentration of the standards were chosen to be within the optimum range, as listed by the EPA GFAA procedures. ${ }^{1}$ Calibration verification, which followed the generation of the calibration curve, consisted of measurements for a calibration blank (CB) and a calibration check standard (CCS). The tolerance limits for CB and CCS have not been set at this time due to a lack of sufficient data to statistically define the limits. Additional QC data was obtained for $\mathrm{CB}$ and CCS at a frequency such that no more than five samples were analyzed between calibration verification samples. For each batch of samples (4-5 samples), an additional divisional QC sample was measured for the elements of interest.

The analysis of samples, which followed the initial calibration verification, included sample and spike measurements, each witt double injections from which the average concentrations were reported or employed for spike recovery calculations. With the double injection for samples and spikes, the analysis of five samples implied twenty furnace injections between QC samples. For concentrations greater than 5 times the Instrument Detection Limit (IDL), the duplicate sample measurement should have agreed within a $30 \%$ relative standard deviation (RSD), or the sample was rerun once. If the RSD still exceeded $30 \%$, the sample was flagged. If the spike recoveries were within the range of $75-125 \%$, the data were quantified directly from the calibration curve and reported to the IDL. If spike recoveries were outside the range, the sample was flagged for a more detailed examination at a later date. Up to this point in the analysis scheme, details are similar to CLP procedures with the exception of the 
broader spike recovery range and duplicate RSD. The CLP procedure specifies analysis by Method of Standard Addition (MSA) when spike recoveries are poor. However, for this work, the MSA technique was not used due to increased sample handling that would increase the radiation exposure to the analyst.

The high sodium nitrate levels found in the active waste tanks was very corrosive to the graphite tube furnaces employed for GFAA. Even with a 5-10 fold dilution of the sample, fewer than 20 sample injections could be completed before ccmpicte destruction of the graphite was observed. Since replacement of the graphite furnace requires recalibration, it was difficult to complete the QA/QC batch ceitification specified by SW-846 with these samples. Although the batch certification discussed above involves more than twenty sample injections, many of the measurements are on standards that do not contain the high sodium nitrate. This problem not only increases the sample analysis time but also involves extensive handling of contaminated equipment and much more radiation exposure time to the analyst.

\section{B.4.10 QAVQC Data and Comments for Metal Analyses}

In general, the QA requirements from SW-846 were employed for all regulatory type measurements. In addition, ACD's blind quality control samples were analyzed with each batch of waste tank samples.

As discussed above, the QC data were obtained on batches of samples. The spike recoveries for the RCRA metals and mercury are listed in Table B.6. The comments on each request are discussed below.

\section{REQUEST IPA6222 (samples: W24-L2, W25-L2, W26-L2, W27-12, W28-L2, W31-L2)}

- The mercury results on samples W24-L2, W25-L2, and W28-L2 are suspect due to spike recovery values less than $75 \%$.

- Thallium results are suspect due to spike recovery value less than $75 \%$.

- The duplicate sample on cadmiurn has a $25 \%$ relative percent error, however, the error bars overlap.

- Cadmium analysis on W26-L2 was repeated and samples W26-L1 and W26-L.3 were analyzed in order to verify the initial findings.

- Although no unusual occurrences were observed with sample W26-L2 in the analyses for potassium and sodium by ICP, the samples were rechecked for sodium and potassium.

- The samples were analyzed for thorium by ICP. No thorium was observed above the IDL except on W26-L2, and this observance seems to be a spectral interference. Sample W26L2 was rerun by colormetric thorium analysis (Thoron procedure). 
Table B,6. RCRA element percent spike recovery tatie

\begin{tabular}{|c|c|c|c|c|c|c|}
\hline bilement & $\underline{\text { IPAG222 }}$ & $1 P A 6223 \& 29$ & IPA6257 & IPA6279 & IPAG282 & IPAn2SS \\
\hline $\mathrm{TI}$ & 70 & 90 & 95 & 91 & 86 & 70 \\
\hline So & 119 & 89 & 109 & 102 & 97 & 177 \\
\hline As & 104 & (9) & 84 & 103 & 138 & 115 \\
\hline$C r$ & 96 & 94 & 92 & $\kappa^{\prime \prime}$ & 75 & או \\
\hline $\mathrm{Pb}$ & 86 & $(x$ & 40 & 82 & $\kappa$ & 1114 \\
\hline (d & 91. & 76 & 62 & 88 & 94 & 10.5 \\
\hline $\mathrm{Ni}$ & 87 & 84 & 92 & 95 & 95 & 97 \\
\hline Ba & 89 & 93 & 99 & 87 & 101 & 9.5 \\
\hline $\mathrm{Ag}$ & 86 & 3 & 3 & -20 & 1 & 12 \\
\hline \\
\hline \multicolumn{7}{|c|}{$\begin{array}{ll}\operatorname{Hg}(W 24-L 2) & 74 \\
\operatorname{llg}(W 25-L 2) & 71\end{array}$} \\
\hline \multicolumn{7}{|c|}{$\lg (W 20-1.2) \quad 86$} \\
\hline \multicolumn{7}{|c|}{$\operatorname{llg}(W 27-L .2)$} \\
\hline \multirow{2}{*}{\multicolumn{7}{|c|}{$\begin{array}{rr}\operatorname{llg}(W 28-1.2) & 67 \\
\lg (W 31-1.2) & 104\end{array}$}} \\
\hline & & & & & & \\
\hline \multicolumn{2}{|c|}{$\operatorname{Hg}(\mathrm{W} 24-\mathrm{S})$} & 114 & & & & \\
\hline \multicolumn{2}{|c|}{$1 \lg (W 25-S)$} & 117 & & & & \\
\hline \multicolumn{2}{|c|}{$1 \mathrm{gg}(\mathrm{W} 28-\mathrm{S})$} & 107 & & & & \\
\hline \multicolumn{2}{|c|}{$\lg (\mathrm{W} 31 \cdot \mathrm{S})$} & 116 & & & & \\
\hline \multicolumn{2}{|c|}{$1 \lg (\mathrm{W} 31-\mathrm{H})$} & 84 & & & & \\
\hline \multicolumn{2}{|c|}{ Matrix spike } & 111 & & & & \\
\hline \multicolumn{2}{|c|}{$\operatorname{Hg}(\mathrm{W} 26-\mathrm{S})$} & & 87 & & & \\
\hline \multicolumn{2}{|c|}{$\operatorname{Hg}(\mathrm{W} 27-\mathrm{H} 1-11)$} & & 121 & & & \\
\hline \multicolumn{2}{|c|}{$1 \lg (\mathrm{W} 27-\mathrm{H} 1-\mathrm{S})$} & & 104 & & & \\
\hline \multicolumn{2}{|c|}{ Matrix spike } & & 167 & & & \\
\hline \multicolumn{2}{|c|}{$\lg (W 21-L 2)$} & & & 89 & & \\
\hline \multicolumn{2}{|c|}{$\lg (\mathrm{W} 23 \cdot \mathrm{L} 1)$} & & & 80 & & \\
\hline \multicolumn{2}{|c|}{$\lg \left(W_{21} \mid S\right)$} & & & & 77 & \\
\hline \multicolumn{2}{|c|}{$\operatorname{lgg}\left(W_{23}-S\right)$} & & & & 97 & \\
\hline \multicolumn{2}{|c|}{ Matrix spike } & & & & 100 & \\
\hline \multicolumn{3}{|c|}{$\operatorname{llg}(W 2 \% \cdot L .1)$} & & & & 82 \\
\hline \multicolumn{3}{|c|}{$\lg (W 29-1.2)$} & & & & 86 \\
\hline \multicolumn{3}{|c|}{$\operatorname{llg}(W 29 \cdot L-4)$} & & & & 75 \\
\hline \multicolumn{3}{|c|}{$\operatorname{Hg}(W 30-1.1)$} & & & & 84 \\
\hline \multicolumn{3}{|c|}{$\lg (\mathrm{W} 30-1.2)$} & & & & 79 \\
\hline \multicolumn{3}{|c|}{$\lg (W 30-1.4)$} & & & & 81 \\
\hline
\end{tabular}

$a^{\prime}(x)=$ over callibration 
REQUEST IPA6223 and IPA6229 (samples: W24-S, W25-S, W'28-S, W31-S, W31-H)

The mercury analysis for sample W28-S was inadvertently skipped and analyzed after the hold time had expired. (Sample W28-S was held 27 d.)

The aliquots for mercury analysis on samples W24-S and W25$\mathrm{S}$ were found to reduce the $5 \% \mathrm{KMnO}_{4}$ in the reaction vessel. This action is probably due to an excess amount of unreacted hydrogen peroxide from the sample preparation.

The ICP external control sample was out of control for selenium.

All of the silver results are suspect due to poor spike recovery $(3 \%)$.

Some of the magnesium and aluminum values were over calibration initially and had to be diluted and reanalyzed. Upon reanalysis, the magnesium external control was out of control.

Precision was poor for the boron analysis by ICP; however, these measurements were done near the detection limit.

Cesium analysis by GFAA was difficult as expected. High (>125\%) spike recovery values encountered on the first analysis attempt. A second analysis attempt produced acceptable spike recoveries, but outof-control results on the calibration verification standards. It is interesting to note that the sample results on both runs were virtually identical.

Density was not measured on W31-H because the sample had dried to hard lumps and, thus, meaningful data could not be obtained.

\section{REQUEST IPA6255 (samples: W29-L1, -L2, -LA, W30-L1, -L2, -LA)}

- Spike recovery on W29-L1, for mercury analysis, was initially $73 \%$ but analysis was repeated at a later date with acceptable results $(82 \%)$.

- The thallium results by ICP are suspect due to low spike recovery $(70 \%)$.

- A difference exists between original analysis and scrial dilution for chromium; however, the serial dilution has a large error bar associated with it (Results are: original $2.4 \pm 0.6 \mathrm{\mu g} / \mathrm{ml}$, vs scrial dilution $1.2 \pm 1 .() \mu \mathrm{g} / \mathrm{ml}$.) 
The silver results are suspect due to poor spike recoveries (12\%).

Initial spike recovery of magnesium was $136 \%$, but the entire magnesium analysis was repeated and the second analysis yielded an acceptable spike recovery $(90 \%)$.

Two external controls were analyzed for sodium, one being outside the control limits. The other control sample was acceptable.

\section{REQUEST IPA6257 (samples: W26-S, W27-H1-H, W27-H1-S)}

- Samples were composited (when appropriate) and sonicated in the hot cells. Sample W27-H1-H could not be sonicated due to its consistency (no interstitial liquid). After digostion, the samples from tank W27 had visual residuc left. This residuc was light gray in color.

Matrix-spiked sample for mercury yielded a higher result than expected (167\% recovery, $150 \%$ recovery on recheck).

The mercury analysis for samples W27-H1-H and W27-H1-S were completed after the hold time had expired. This delay was the result of environmental problems in the laboratory (ic. elevated radon levels in laboratory). (The samples were held for $28 \mathrm{~d}$.)

Spike recoveries for lead and cadmium were $40 \%$ and $62 \%$, respectively.

The lead analysis was initially over calibration and had to be reanalyzed on a second calibration curve.

The diplicate samples for this batch checked well.

The boron was measured at the 208.959-nm emission line. The $249.773-\mathrm{nm}$ line was not employed due to a spectral interference at that wavelength.

Initially, there was a variation in the sample handling, and the samples were not sonicated prior to sample dissolution. Upon attempting the mercury analysis, great differenecs were observed between the original sample and duplicale. This discrepancy demonstrates that the sludge samples lack homogereity. The attempt to analyze these preps was aborted, and the samples were composited and reprepared for analysis. 


\section{REQUEST IPA6279 (samples: W21-L2, W23-L1)}

Arsenic value on W21-L2 is suspect. This value is very close to the IDL, and the large error bar indicates that the value is probably due to excessive baseline noise (As result $=3.8 \pm$ $7.3 \mu \mathrm{g} / \mathrm{ml})$.

- No chromium spike recovery was calculated since the spiked sample vas over calibration.

- There was a discrepancy between the original and duplicate sample for thallium analysis; however, there was a large error bar on the duplicate, and the values were close to the IDL.

- The presence of cadmium and nickel were verified at alternate wavelengths in the graphics spectrum mode.

The aluminum emission line at $309.271 \mathrm{~nm}$ could not be used due to spectral interferences, so the 396.152-nm line was employed instead.

\section{REQUEST IPA6282 (samples: W21-S, W23-S)}

- The holding time for mercury on these samples had expired due to hardware problems with the Perkin-Elmer 5100 spectrometer. The samples were held for $22 \mathrm{~d}$.

- The arsenic values are suspect due to a spike recovery of $138 \%$. Also, there was a large error bar associated with arsenic analysis of sample W21-S.

- No spike recovery was calculated for lead as this result was over calibration.

Duplicate sample on the $\mathrm{Pb}$ analysis had a $32 \%$ Relative Percent Difference (RPD) value, but there was a large error bar on the duplicate (i.e. original $\mathrm{Pb}=450 \pm 60 \mu \mathrm{g} / \mathrm{ml} \mathrm{vs}$ duplicate $\mathrm{Pb}=620 \pm 250 \mathrm{\mu g} / \mathrm{ml}$ ).

The aluminum emission line at $309.271 \mathrm{~nm}$ could not be used due to spectral interferences, so the 396.152-nm line was employed instead.

The boron emission line at $249.773 \mathrm{~nm}$ could not be used due to spectral interferences, so the 208.959-nm line was employed instead. 


\section{B.5 RADIOCHEMICAL MEASUREMENTS}

The radiochemical characterization of the waste tanks included gross alpha, gross beta, gamma spectrometry, strontium-90, and actinides by alpha spectrometry. To ensure valid data, all of the above radiochemical measurements except the alpha spectrometry were duplicated by two separate laboratories. A brief description of the radiochemical methods are listed in Table B.5, along with typical detection limits. In addition, carbon-14 and tritium were determined by liquid scintillation on all liquid samples, and carbon-14 was determined for all sludge samples. Although not measured for this project, it is recommended that both technetium-99) $\left(t_{1 / 2}=2.13 \times 10^{5} \mathrm{y}\right)$ and iodine-129 $\left(t_{1 / 2}=1.6 \times 10^{7} \mathrm{y}\right)$ be determined on selected samples from this project.

Most of the radiochemcial data presented in the surnmary tables in Sect. 4 are from the Transuranium Analytical Laboratory (TAL) to provide a consistent data package from one laboratory. The ${ }^{\text {so }} \mathrm{Sr}$ data are from the IPA because of the experience of the analyst performing the testing. Tritium and ${ }^{14} \mathrm{C}$ data are also from the IPA. Results that were duplicated by iwo separate laboratories are presented in Appendix C.

\section{B.5.1 Sample Preparation for Alpha Counting}

A rapid and reliable mothod was needed to prepare clean alpha plates from samples of the LLLW concentrates. Excessive solid materials on alpha plates led to self absorption, llaking, and poor alpha spectrometry for isotopic determination. The method used to ciean up these samples is based on a double precipitation with ferric iron. Ferric nitrate is first added to the sample solution, which is then heated to boiling, followed by dropwise addition of $\mathrm{NH}_{4} \mathrm{OH}$ 10 precipitate what is best described as hydrous ferric oxide $\left(\mathrm{Fe}_{2} \mathrm{O}_{3}-\mathrm{nH}_{2} \mathrm{O}\right.$, but is commonly called ferric hydroxide). Yields in excess of $97 \%$ for uranium and the transuranic actinides have been reported for coprecipitation with ferric hydroxide. ${ }^{7}$ A test solution was prepared with three isotopes found in waste tank samples.

Table B.7. Composition of alpha test solution

\begin{tabular}{llrr}
\hline Isotope & $\begin{array}{c}\text { Energy } \\
(\mathrm{MeV})\end{array}$ & $\begin{array}{r}\text { Activity } \\
\text { Ratio }\end{array}$ & $\begin{array}{r}\text { Activity } \\
(\mathrm{Bc} / \mathrm{mL})\end{array}$ \\
\hline${ }^{233} \mathrm{U}$ & 4.82 & $34.0 \%$ & 659.6 \\
${ }^{240} \mathrm{Pu}$ & 5.15 & $44.6 \%$ & 865.2 \\
${ }^{241} \mathrm{Am}$ & 5.50 & $21.4 \%$ & 415.2 \\
& & Total: & $1940 \mathrm{~Bq} / \mathrm{mL}$ \\
\hline
\end{tabular}

Results on 2 aliquots of the above solution with double ferric hydroxide precipitations to separate and recover the actinides are given in Table B.8. 
Table B.8. Recovery of actinides from test solution

\begin{tabular}{lllll}
$\begin{array}{l}\text { Gross } \\
\text { Alpha } \\
(\mathrm{Bq} / \mathrm{mL})\end{array}$ & ${ }^{233} \mathrm{U}$ & $\begin{array}{l}{ }^{240} \mathrm{Pu} \\
(\%)\end{array}$ & $\begin{array}{l}{ }^{241} \mathrm{Am} \\
(\%)\end{array}$ & $\begin{array}{l}\text { Recovery } \\
(\%)\end{array}$ \\
\hline 1900 & 31.9 & 45.3 & 22.8 & 98 \\
1960 & 33.9 & 44.2 & 21.9 & 103 \\
\hline
\end{tabular}

Four dissolved sludge samples were analyzed for alpha concentration and isotopic composition. The alpha concentration was determined with to precipitation, a single ferric hydroxide precipitation, and a double ferric hydroxide precipitation. Results were as follows:

Table B.9. Alpha recovery for actual sludge samples

\begin{tabular}{lllll}
\hline $\begin{array}{l}\text { Sludge } \\
\text { sample }\end{array}$ & $\begin{array}{l}\text { No } \\
\mathrm{ppt} .\end{array}$ & $\begin{array}{l}\text { Single } \\
\text { Fe ppt. } \\
(\mathrm{Bq} / \mathrm{gq})\end{array}$ & $\begin{array}{l}\text { Double } \\
\text { Fe ppt. } \\
(\mathrm{Bq} / \mathrm{g})\end{array}$ & $\begin{array}{l}\text { \% Lost } \\
\text { No ppt. }\end{array}$ \\
& & & \\
\hline & & & & \\
\hline & 17,100 & 18,400 & 22,300 & 23 \\
3 & 62,000 & 67,300 & 83,800 & 26 \\
4 & 84,900 & 105,000 & 99,700 & 15 \\
& 147,000 & 165,000 & 204,000 & 28 \\
\hline
\end{tabular}

Due to excessive solids, the isotopic composition could not be determined on the waste tank samples that were plated directly. There was no significant difference in the pulse-height analysis (PHA) of the single and double iron precipitates. This method is reliable, rapid, and generates very little waste. It can easily be carried out on samples with low alpha activity and results in minimal dilution of the sample (dilution factor less than 5). 
Table B.10. Typical gross alpha spike recoveries for liquid samples

\begin{tabular}{|c|c|c|c|c|c|}
\hline \multicolumn{2}{|c|}{ IPA 6222} & \multicolumn{2}{|c|}{ IPA 6255} & \multicolumn{2}{|c|}{ IPA 6279} \\
\hline Sample : & $\begin{array}{l}\text { Spike } \\
\text { recovery } \\
(\%)\end{array}$ & Sample & $\begin{array}{l}\text { Spike } \\
\text { recovery } \\
(\%)\end{array}$ & Sample & $\begin{array}{l}\text { Spike } \\
\text { recovery } \\
(\%)\end{array}$ \\
\hline W24-L2 & 77 & W29.L1 & 87 & W21-L2 & 85 \\
\hline W25-L2 & 75 & W29-L2 & 83 & W23-L1 & 8.3 \\
\hline W26-L2 & 75 & W29-L4 & 86 & & \\
\hline W27-L.2 & 78 & W30-L1 & 89 & & \\
\hline$W 28-L 2$ & 77 & W30.L2 & 88 & & \\
\hline W31-L2 & 77 & W3()-L4 & 86 & & \\
\hline
\end{tabular}

\section{B.5.2 Instrumentation}

The gross alpha and gross beta measurements were done on 2-pi gas-flow proportional counters. Also, a Ludlum alpha scintillation counter was employed for gross alpha measurements. All the gross alpha data reported in the summary tables were taken from the alpha scintillation counter because of its superior performance in the presence of a high bela background. Several Tenneled high purity germanium (HPGe) detectors, with a nominal efficiency of $25 \%$, were employed for all gamma spectroscopy measurements - all spectral data was processed with Nuclear Data software. The alpha spectroscopy was done on both Tennelec TC-256 alpha spectrometers or a Canberra Quad Four alpha spectrometer, using surface barrier detectors which had active areas that ranged from $300-1000 \mathrm{~mm}^{2}$. Carbon-14 and tritium measurements were done on a Packard 2500TR liquid scintillation system.

\section{B.5.3 Carbon-14}

The Dohrmann DC-90 carbon analyzer is equipped with a combustion tube for solids analysis that was adapted to the analysis of ${ }^{14} \mathrm{C}$. In this procedure, samples were heated to $9000^{\circ} \mathrm{C}$ to volatilize organic compounds and decompose carbonates. The furnace was continually sparged with oxygen and all off-gases passed through an oxidizing bed (cobalt oxide) to convert organic species to carbon dioxide. Samples were collected in gas washing bottles filled with a carbon dioxide-absorbent solution. Aliquots of the carbon dioxide absorber solutions viere pipetted into a compatible liquid scintillation cocktail and counted. 


\section{B.5.4 Quality Control}

As mentioned earlier, many of the radiochemical measurements were duplicated by two separate laboratories. The duplicated measurements included gross alpha, gross beta, gamma spectroscopy, and strontium-90 measurements. Also, duplicate measurements were done for most radiochemical measurements by each laboratory. Finally, both laboratories particirate in the ACD Qr, that involves the measurement of blind QC samples. 


\section{B.6 REFERENCES}

1. U.S. Environmental Protection Agency, Test Methods for Evaluating Solid Wastc, SW-846, 3rd ed., November 1986.

2. U.S. Environmental Protection Agency, Statement of Work for Inorganic Analysis, SOW No. 787.

3. U.S. Environmental Protection Agency, Methods for Chemical Analysis of Watcr and Wastes, EPA-600/4-79-020, Revised March 1983.

4. A. O. Allen, The Radiation Chemistry of Water and Aqueous Solutions, D. Van Nostrand Company Inc., 1961.

5. W. Slavin, D. C. Manning, and G. R. Carnrick, The Stabilized Temperature Platform Furnace, Atomic Spectroscopy, Vol. 2, No. 5, pp. 137-145 (1981).

6. G. R. Carnrick and W. Slavin, Modern Graphite Furnace AA: Part 2, Americar: Laboratory, pp. 90-95, February 1989.

7. G. T. Seaborg and J. J. Katz, The Actinide Elements, Vol. IV-14A, McGraw-Hill Book Company, Inc., 1954, pp. 545-591. 
APPENDIX C

COMPREHENSIVE LISTING OF PHYSICAL, INORGANIC, AND

RADIOCHEMICAL ANALYTICAL DATA. 
Physical properties and miscellaneous data

$\begin{array}{lll}\mathrm{TDS}^{\mathrm{C}} & (\mathrm{mg} / \mathrm{mL}) & 393 \\ \mathrm{TS}^{\mathrm{d}} & (\mathrm{mg} / \mathrm{mL}) & 421\end{array}$

$\begin{array}{lll}\text { Density } & (\mathrm{g} / \mathrm{mL}) & 1.2391 \\ & & \\ \mathrm{IC}^{\mathrm{e}} & (\mathrm{mg} / \mathrm{L}) & <1.0 \\ \mathrm{TC}^{\mathrm{f}} & (\mathrm{mg} / \mathrm{L}) & 571 \\ \text { TOC }^{\mathrm{g}} & (\mathrm{mg} / \mathrm{L}) & 571\end{array}$

\section{$\underline{\text { RCRA metals }}$}

\begin{tabular}{|c|c|c|}
\hline $\mathrm{Ag}$ & $(\mathrm{mg} / \mathrm{L})$ & 1.2 \\
\hline As & $(\mathrm{mg} / \mathrm{L})$ & 3.8 \\
\hline $\mathrm{Ba}$ & $(\mathrm{mg} / \mathrm{L})$ & 25 \\
\hline $\mathrm{Cd}$ & $(\mathrm{mg} / \mathrm{L})$ & 2.0 \\
\hline $\mathrm{Cr}$ & $(\mathrm{mg} / \mathrm{L})$ & 27 \\
\hline $\mathrm{Hg}$ & $(\mathrm{mg} / \mathrm{L})$ & 0.92 \\
\hline $\mathrm{Ni}$ & $(\mathrm{mg} / \mathrm{L})$ & 15 \\
\hline $\mathrm{Pb}$ & $(\mathrm{mg} / \mathrm{L})$ & 7.1 \\
\hline $\mathrm{Se}$ & $(\mathrm{mg} / \mathrm{L})$ & $<2.3$ \\
\hline $\mathrm{T}]$ & $(\mathrm{mg} / \mathrm{L})$ & $<0.94$ \\
\hline
\end{tabular}

\section{Process metals}

$\begin{array}{lcc}\mathrm{Al} & (\mathrm{mg} / \mathrm{L}) & <1.2 \\ \mathrm{~B} & (\mathrm{mg} / \mathrm{L}) & 1.0 \\ \mathrm{Ca} & (\mathrm{mg} / \mathrm{L}) & 23000 \\ \mathrm{Fe} & (\mathrm{mg} / \mathrm{L}) & 240 \\ \mathrm{~K} & (\mathrm{mg} / \mathrm{L}) & 20000 \\ \mathrm{Mg} & (\mathrm{mg} / \mathrm{L}) & 5600 \\ \mathrm{Na} & (\mathrm{mg} / \mathrm{L}) & 61000 \\ \mathrm{Si} \text { (color) } & (\mathrm{mg} / \mathrm{L}) & <1.0 \\ \mathrm{Sr} & (\mathrm{mg} / \mathrm{L}) & 160 \\ \mathrm{Th} \text { (color) } & (\mathrm{mg} / \mathrm{L}) & - \\ \mathrm{U} \text { (fluor) } & (\mathrm{mg} / \mathrm{L}) & 750\end{array}$


TAL

Anions (analyzed by CPA Lab.) ${ }^{h}$

$\begin{array}{llc}\text { Chloride } & (\mathrm{mg} / \mathrm{L}) & 2.10 \mathrm{e}+03^{\mathrm{i}} \\ \text { Fluoride } & (\mathrm{mg} / \mathrm{L}) & <1.0 \mathrm{e}+03 \\ \text { Nitrate } & (\mathrm{mg} / \mathrm{L}) & 3.10 \mathrm{c}+05 \\ \text { Phosphate } & (\mathrm{mg} / \mathrm{L}) & <5.0 \mathrm{c}+03 \\ \text { Sulfate } & (\mathrm{mg} / \mathrm{L}) & <5.0 \mathrm{e}+0.3\end{array}$

Alkalinity

$\begin{array}{ll}\mathrm{pH} & (\underline{\mathrm{M}}) \\ \mathrm{H}^{+} & (\underline{\mathrm{M}}) \\ \mathrm{OH}^{-} & (\underline{\mathrm{M}}) \\ \mathrm{CO}_{3}{ }^{2 \cdot} & (\underline{\mathrm{M}})\end{array}$

Beta/gamma cmitters

\begin{tabular}{llcc}
\hline Gross alpha & $(\mathrm{Bq} / \mathrm{mL})$ & $1.67 \mathrm{e}+03$ & $2.14 \mathrm{e}+03$ \\
Gross beta & $(\mathrm{Bq} / \mathrm{mL})$ & $4.24 \mathrm{e}+05$ & $4.99 \mathrm{e}+05$ \\
${ }^{14} \mathrm{C}$ & $(\mathrm{Bq} / \mathrm{mL})$ & $<1 .(1 \mathrm{e}+00$ & - \\
${ }^{144} \mathrm{Ce}$ & $(\mathrm{Bq} / \mathrm{mL})$ & - & $<1.5 \mathrm{e}+03$ \\
${ }^{60} \mathrm{Co}$ & $(\mathrm{Bq} / \mathrm{mL})$ & $8.62 \mathrm{e}+03$ & $8.50 \mathrm{e}+03$ \\
${ }^{134} \mathrm{Cs}$ & $(\mathrm{Bq} / \mathrm{mL})$ & $5.22 \mathrm{e}+03$ & $5.12 \mathrm{e}+03$ \\
${ }^{1.37} \mathrm{Cs}$ & $(\mathrm{Bq} / \mathrm{mL})$ & $3.21 \mathrm{e}+0$. & $3.19 \mathrm{e}+05$ \\
${ }^{152} \mathrm{Eu}$ & $(\mathrm{Bq} / \mathrm{mL})$ & $3.58 \mathrm{e}+04$ & $3.31 \mathrm{e}+04$ \\
${ }^{15.4} \mathrm{Eu}$ & $(\mathrm{Bq} / \mathrm{mL})$ & $1.63 \mathrm{e}+04$ & $1.66 \mathrm{e}+04$ \\
${ }^{15.5} \mathrm{Eu}$ & $(\mathrm{Bq} / \mathrm{mL})$ & $4.77 \mathrm{e}+03$ & $5.22 \mathrm{e}+03$ \\
${ }^{3} \mathrm{H}$ & $(\mathrm{Bq} / \mathrm{mL})$ & $3.50 \mathrm{e}+02$ & - \\
${ }_{95}^{95} \mathrm{Nb}$ & $(\mathrm{Bq} / \mathrm{mL})$ & - & $<1.5 \mathrm{e}+02$ \\
${ }^{106} \mathrm{Ru}$ & $(\mathrm{Bq} / \mathrm{mL})$ & - & $1.95 \mathrm{e}+03$ \\
${ }_{90}^{90} \mathrm{Sr}$ & $(\mathrm{Bq} / \mathrm{mL})$ & $7.46 \mathrm{c}+04$ & $7.64 \mathrm{E}+04$ \\
${ }^{95} \mathrm{Zr}$ & $(\mathrm{Bq} / \mathrm{mL})$ & - & $<7.1 \mathrm{e}+03$
\end{tabular}

\section{Alpha emitters}

$\begin{array}{ll}{ }^{221} \mathrm{U} & (\mathrm{Bq} / \mathrm{mL}) \\ { }^{273} \mathrm{U} & (\mathrm{Bq} / \mathrm{mL}) \\ { }^{279} \mathrm{Pu} /{ }^{40} \mathrm{Pu} & (\mathrm{Bq} / \mathrm{mL}) \\ { }^{278} \mathrm{Pu} /{ }^{241} \mathrm{Am} & (\mathrm{Bq} / \mathrm{mL}) \\ { }^{241} \mathrm{Cm} & (\mathrm{Bq} / \mathrm{mL})\end{array}$

aIPA = Inorganic and Physical Analysis.

$\begin{array}{ll}0.75 & 0.56 \\ - & 0.085 \\ - & - \\ - & - \\ - & -\end{array}$

$b_{T A L}=$ Transuranium Analytical Laboratory.

TDS = total dissolved solids.

d. TS = total solids.

$\mathrm{c}_{\mathrm{IC}}=$ inorganic carbon.

$6.80 \mathrm{e}+01$

$3.96 \mathrm{c}+02$

$6.20 \mathrm{e}+01$

$2.61 \mathrm{c}+02$

$1.15 \mathrm{c}+(0) 3$

$\mathrm{i}_{\mathrm{TC}}=$ total carbon.

gTOC = total organic carbon.

${ }^{h} \mathrm{CPA}=$ Chemical and Physical Analysis.

${ }^{\mathrm{i}}$ Read as $2.10 \times 10^{3}$. 
Physical propertics and miscellancous data

TDS

TS

Density

IC

TC

TOC

$\begin{array}{ll}(\mathrm{mg} / \mathrm{mL}) & 381 \\ (\mathrm{mg} / \mathrm{mL}) & 383\end{array}$

$(\mathrm{g} / \mathrm{mL})$

1.2423

$(\mathrm{mg} / \mathrm{L})$

(mg/L)

(mg/L)

\section{RCRA metals}

Ag

As

Ba

$\mathrm{Cd}$

$\mathrm{Cr}$

$\mathrm{Hg}$

$\mathrm{Ni}$

$\mathrm{Pb}$

Se

TI

$(\mathrm{mg} / \mathrm{L})$
$(\mathrm{mg} / \mathrm{L})$
$(\mathrm{mg} / \mathrm{L})$
$(\mathrm{mg} / \mathrm{L})$
$(\mathrm{mg} / \mathrm{L})$
$(\mathrm{mg} / \mathrm{L})$
$(\mathrm{mg} / \mathrm{L})$
$(\mathrm{mg} / \mathrm{L})$
$(\mathrm{mg} / \mathrm{L})$
$(\mathrm{mg} / \mathrm{L})$

$$
<0.44
$$$$
<3.0
$$$$
<0.19
$$

1.7

0.42

0.07

3.0

2.7

$<2.3$

$<0.94$

Process metals

Al

B

$\mathrm{Ca}$

$\mathrm{FC}$

$\mathrm{K}$

$\mathrm{Mg}$

$\mathrm{Na}$

Si (color)

$\mathrm{Sr}$

Th (color)

U (fluor) $(\mathrm{mg} / \mathrm{L})$ ( $\mathrm{mg} / \mathrm{L}$ )

$(\mathrm{mg} / \mathrm{L})$

(mg/L)

(mg/L)

(mg/L)

(mg/L)

( $\mathrm{mg} / \mathrm{L}$ )

$(\mathrm{mg} / \mathrm{L})$

(mg/L)

(mg/L)

1.8
10
18
0.70
78000
3.4
$820(0)$
$<1.0$
0.40
-
17




\section{Anions (analyzed by CPA Lab.)}

$\begin{array}{ll}\text { Chloride } & (\mathrm{mg} / \mathrm{L}) \\ \text { Fluoride } & (\mathrm{mg} / \mathrm{L}) \\ \text { Nitrate } & (\mathrm{mg} / \mathrm{L}) \\ \text { Phosphate } & (\mathrm{mg} / \mathrm{L}) \\ \text { Sulfute } & (\mathrm{mg} / \mathrm{L})\end{array}$

$$
\begin{aligned}
& 3.60 \mathrm{c}+03 \\
&< 1.0 \mathrm{e}+03 \\
& 2.00 \mathrm{c}+05 \\
&< \\
&<.0 \mathrm{e}+03 \\
& 7.80 \mathrm{c}+0.3
\end{aligned}
$$

Alkalinity

$\begin{array}{lccc}\mathrm{pH} & & 12.8 & 12.8 \\ \mathrm{OH} & (\underline{\mathrm{M}}) & - & 0.15 \\ \mathrm{CO}_{3}^{2 .} & (\underline{\mathrm{M}}) & - & 0.70 \\ \mathrm{HCO}_{3} & (\underline{\mathrm{M}}) & - & -\end{array}$

\section{Beta/gamma emitters}

$\begin{array}{lllc}\text { Gross alpha } & (\mathrm{Bq} / \mathrm{mL}) & 6.80 \mathrm{c}+01 & 8.20 \mathrm{e}+01 \\ \text { Gross beta } & (\mathrm{Bq} / \mathrm{mL}) & 4.15 \mathrm{c}+05 & 4.62 \mathrm{c}+05 \\ { }^{14} \mathrm{C} & (\mathrm{Bq} / \mathrm{mL}) & 6.35 \mathrm{c}+01 & - \\ { }^{144} \mathrm{Ce} & (\mathrm{Bq} / \mathrm{mL}) & - & <1.6 \mathrm{c}+03 \\ { }^{60} \mathrm{Co} & (\mathrm{Bq} / \mathrm{mL}) & 5.97 \mathrm{c}+02 & 6.21 \mathrm{e}+02 \\ { }^{13.4} \mathrm{Cs} & (\mathrm{Bq} / \mathrm{mL}) & 4.48 \mathrm{c}+03 & 4.63 \mathrm{c}+03 \\ { }^{1.37} \mathrm{Cs} & (\mathrm{Bq} / \mathrm{mL}) & 4.52 \mathrm{c}+05 & 4.36 \mathrm{c}+05 \\ { }^{152} \mathrm{Eu} & (\mathrm{Bq} / \mathrm{mL}) & <8.8 \mathrm{e}+02 & <2.1 \mathrm{c}+02 \\ { }^{15.4} \mathrm{Eu} & (\mathrm{Bq} / \mathrm{mL}) & <2.2 \mathrm{c}+02 & <1.6 \mathrm{c}+02 \\ { }^{155} \mathrm{Eu} & (\mathrm{Bq} / \mathrm{mL}) & <7.7 \mathrm{e}+02 & <8.5 \mathrm{c}+02 \\ { }^{3} \mathrm{H} & (\mathrm{Bq} / \mathrm{mL}) & 1.19 \mathrm{e}+02 & - \\ { }^{95} \mathrm{Nb} & (\mathrm{Bq} / \mathrm{mL}) & - & <1 .(0 \mathrm{c}+02 \\ { }^{106} \mathrm{Ru} & (\mathrm{Bq} / \mathrm{mL}) & - & 3.78 \mathrm{c}+(03 \\ { }^{90} \mathrm{Sr} & (\mathrm{Bq} / \mathrm{mL}) & 4.12 \mathrm{c}+(02 & 4.36 \mathrm{c}+02 \\ { }^{95} \mathrm{Zr} & (\mathrm{Bq} / \mathrm{mL}) & - & <1 .(1) \mathrm{c}+() 2\end{array}$

\section{Alpha emitters}

$\begin{array}{llll}{ }^{222} \mathrm{U} & (\mathrm{Bq} / \mathrm{mL}) & - & 4.00 \mathrm{c}+(0) \\ { }^{23 .} \mathrm{U} & (\mathrm{Bq} / \mathrm{mL}) & - & 6.00 \mathrm{c}+(0) \\ { }^{230} \mathrm{Pu} /{ }^{40} \mathrm{Pu} & (\mathrm{Bq} / \mathrm{mL}) & - & 6.00 \mathrm{c}+(0) \\ { }^{238} \mathrm{Pu} /{ }^{241} \mathrm{Am} & (\mathrm{Bg} / \mathrm{mL}) & -. & 3.90 \mathrm{c}+01 \\ { }^{291} \mathrm{Cm} & (\mathrm{Bg} / \mathrm{mL}) & - & 4.00 \mathrm{c}+(0)\end{array}$


Physical propertics and miscellancous data

TDS $\quad(\mathrm{mg} / \mathrm{mL}) \quad 377$

TS $\quad(\mathrm{mg} / \mathrm{mL}) \quad 383$

$\begin{array}{lcc}\text { Density } & (\mathrm{g} / \mathrm{mL}) & 1.2348 \\ & & \\ \text { IC } & (\mathrm{mg} / \mathrm{L}) & 1910 \\ \text { TC } & (\mathrm{mg} / \mathrm{L}) & 24(0.0 \\ \text { TOC } & (\mathrm{mg} / \mathrm{L}) & 489\end{array}$

\section{$\frac{\text { RCRA mctals }}{A g}$}

\begin{tabular}{|c|c|c|}
\hline $\mathrm{Ag}$ & $(\mathrm{mg} / \mathrm{L})$ & $<0.69$ \\
\hline As & $(\mathrm{mg} / \mathrm{L})$ & $<3.7$ \\
\hline $\mathrm{Ba}$ & $(\mathrm{mg} / \mathrm{L})$ & 0,29 \\
\hline $\mathrm{Cd}$ & $(\mathrm{mg} / \mathrm{L})$ & 0.22 \\
\hline $\mathrm{Cr}$ & $(\mathrm{mg} / \mathrm{L})$ & 3.1 \\
\hline $\mathrm{Hg}$ & $(\mathrm{mg} / \mathrm{L})$ & 0.04 \\
\hline $\mathrm{Ni}$ & $(\mathrm{mg} / \mathrm{L})$ & $<0,38$ \\
\hline $\mathrm{Pb}$ & $(\mathrm{mg} / \mathrm{L})$ & 6.7 \\
\hline $\mathrm{Se}$ & $(\mathrm{mg} / \mathrm{L})$ & $<4.7$ \\
\hline $\mathrm{Tl}$ & $(\mathrm{mg} / \mathrm{L})$ & $<1.4$ \\
\hline
\end{tabular}

\section{Process metals}

$\begin{array}{lcc}\mathrm{Al} & (\mathrm{mg} / \mathrm{L}) & 46 \\ \mathrm{~B} & (\mathrm{mg} / \mathrm{L}) & 0.95 \\ \mathrm{Ca} & (\mathrm{mg} / \mathrm{L}) & 7.2 \\ \mathrm{Co} & (\mathrm{mg} / \mathrm{L}) & <0.57 \\ \mathrm{Fc} & (\mathrm{mg} / \mathrm{L}) & <2.6 \\ \mathrm{~K} & (\mathrm{mg} / \mathrm{L}) & 11(00) \\ \mathrm{Mg} & (\mathrm{mg} / \mathrm{L}) & <1.3 \\ \mathrm{Na} & (\mathrm{mg} / \mathrm{L}) & 100(0) 0 \\ \mathrm{Si} \text { (color) } & (\mathrm{mg} / \mathrm{L}) & 245 \\ \mathrm{Sr} & (\mathrm{mg} / \mathrm{L}) & <0.74 \\ \mathrm{Tr} \text { (ICP) } & (\mathrm{mg} / \mathrm{L}) & <2.2 \\ \mathrm{U} \text { (lluor) } & (\mathrm{mg} / \mathrm{L}) & 9.4\end{array}$


Anions (analyzed by CPA Lab.)

$\begin{array}{llc}\text { Chloride } & (\mathrm{mg} / \mathrm{L}) & 2.60 \mathrm{c}+03 \\ \text { Fluoride } & (\mathrm{mg} / \mathrm{L}) & <5 .(0 \mathrm{c}+02 \\ \text { Nitrate } & (\mathrm{mg} / \mathrm{L}) & 2.60 \mathrm{e}+05 \\ \text { Phosphate } & (\mathrm{mg} / \mathrm{L}) & <5.0 \mathrm{c}+0.3 \\ \text { Sultate } & (\mathrm{mg} / \mathrm{L}) & <5 .(\mathrm{e}+0.3\end{array}$

\section{Alkalinity}

$\begin{array}{lrrr}\mathrm{pH} & & \cdot & 13.1 \\ \mathrm{OH}^{\circ} & (\underline{\mathrm{M}}) & \cdot & 0.29 \\ \mathrm{CO}_{3}{ }^{2} & (\underline{\mathrm{M}}) & \cdot & 0.15 \\ \mathrm{HCO}_{3}{ }^{\circ} & (\underline{\mathrm{M}}) & - & <0.01\end{array}$

\section{Beta/gamma cmitters}

\begin{tabular}{|c|c|c|c|}
\hline Gross alpha & $(\mathrm{Bq} / \mathrm{mL})$ & $1.05 c+01$ & $5 .(0) \mathrm{e}+(x)$ \\
\hline Gross beta & $(\mathrm{Bc} / \mathrm{mL})$ & $2.05 c+0.5$ & $2.30 \mathrm{c}+0.5$ \\
\hline${ }^{14} \mathrm{C}$ & $(\mathrm{Bq} / \mathrm{mL})$ & $7.87 \mathrm{e}+(02$ & - \\
\hline${ }^{144} \mathrm{Ce}$ & $(\mathrm{Bc} / \mathrm{mL})$ & . & $<7.4 c+() 2$ \\
\hline${ }^{n 0} \mathrm{Co}$ & $(\mathrm{Bq} / \mathrm{mL})$ & $4.06 \mathrm{c}+02$ & $3.29 \mathrm{c}+(12$ \\
\hline${ }^{1.34} \mathrm{Cs}$ & $(\mathrm{Bq} / \mathrm{mL})$ & $1.13 c+0.3$ & $1.34 c+03$ \\
\hline${ }^{1.37} \mathrm{C}^{4} \mathrm{~s}$ & $(\mathrm{Bg} / \mathrm{mL})$ & $2.24 c+05$ & $2.21 \mathrm{c}+0.5$ \\
\hline${ }^{152} \mathrm{Eu}$ & $(\mathrm{Bi} / \mathrm{mL})$ & - & $<3.2 c+() 2$ \\
\hline${ }^{15.4} \mathrm{Eu}$ & $(\mathrm{Bq} / \mathrm{mL})$ & . & $<6.0 \mathrm{c}+01$ \\
\hline${ }^{15 s} \mathrm{Eu}$ & $(\mathrm{Bq} / \mathrm{mL})$ & - & $<4 .(1)+() 2$ \\
\hline${ }^{3} \mathrm{H}$ & $(\mathrm{Bq} / \mathrm{mL})$ & $3.08 \mathrm{c}+\left(02^{\mathrm{a}}\right.$ & - \\
\hline${ }^{95} \mathrm{Nb}$ & $(\mathrm{Bq} / \mathrm{mL})$ & - & $<2.8 c+() 2$ \\
\hline${ }^{1 *} R u$ & $(\mathrm{~Bq} / \mathrm{mL})$ & - & $<1.1 \mathrm{c}+(03$ \\
\hline${ }^{*} \mathrm{Sr}$ & $(\mathrm{Bq} / \mathrm{mL})$ & $9.13 c+(1) 2$ & $8.86 x+02$ \\
\hline${ }^{95} \mathrm{Zr}$ & $(\mathrm{Bq} / \mathrm{mL})$ & - & $<5 .() c+(1) 2$ \\
\hline
\end{tabular}

"Tritium determined on sample: W'24-L1. 
C.8

Sample: W25-L2

IPA

TAL

Physical proportics and miscollaneous data

TDS

(mg/mL)

348

TS

$(\mathrm{mg} / \mathrm{mL})$

334

Density

$(\mathrm{g} / \mathrm{mL})$

1.2018

IC

TC

$(\mathrm{mg} / \mathrm{L})$

15.8

TOC

$(\mathrm{mg} / \mathrm{L})$

478

$(\mathrm{mg} / \mathrm{L})$

462

RCRA motuls

$\mathrm{Ag}$

As

$\mathrm{Ba}$

$\mathrm{Cd}$

$\mathrm{Cr}$

$\mathrm{Hg}$

$\mathrm{Ni}$

$\mathrm{Pb}$

$\mathrm{Sc}$

TI $(\mathrm{mg} / \mathrm{L})$

$(\mathrm{mg} / \mathrm{L})$

( $\mathrm{mg} / \mathrm{L})$

$(\mathrm{mg} / \mathrm{L})$

$(\mathrm{mg} / \mathrm{L})$

$(\mathrm{mg} / \mathrm{L})$

$(\mathrm{mg} / \mathrm{L})$

$(\mathrm{mg} / \mathrm{L}$ )

$(\mathrm{mg} / \mathrm{L})$

$(\mathrm{mg} / \mathrm{L})$
$<(1,69$

$<3.7$

3.2

$<0.12$

1.9

0.054

0.45

$<2.1$

$<4.7$

$<1.4$

Process motals

$\mathrm{Al}$

B

$\mathrm{Ca}$

$\mathrm{Co}$

$\mathrm{FC}$

$\mathrm{K}$

$\mathrm{Nig}$

$\mathrm{Na}$

$\mathrm{Si}$

$\mathrm{Sr}$

Th (ICP)

$\mathrm{U}$ (fluor) $(\mathrm{mg} / \mathrm{L})$

$(\mathrm{mg} / \mathrm{L}$.)

$(\mathrm{mg} / \mathrm{L})$

(mg/L)

$(\mathrm{mg} / \mathrm{L})$

(mg/L)

(ng/L)

$(\mathrm{mg} / \mathrm{L})$

$(\mathrm{mg} / \mathrm{L})$

$(\mathrm{mg} / \mathrm{L})$

(mg/L)

$(\mathrm{mg} / \mathrm{L})$
$<4.2$

0.60

280

$<0.57$

$<2.6$

$17(0) 1)$

$<1.3$

$78000)$

$<1.0$

23

$<2.2$

$<(0.1)$ 


\section{Anions (analyzed by CPA Lab.)}

$\begin{array}{llc}\text { Chloride } & (\mathrm{mg} / \mathrm{L}) & 2.50 \mathrm{c}+03 \\ \text { Fluoride } & (\mathrm{mg} / \mathrm{L}) & <5 .(\mathrm{c}+02 \\ \text { Nitrate } & (\mathrm{mg} / \mathrm{L}) & 2.60 \mathrm{c}+05 \\ \text { Phosphate } & (\mathrm{mg} / \mathrm{L}) & <5.0 \mathrm{c}+(03 \\ \text { Sulfate } & (\mathrm{mg} / \mathrm{L}) & <5.0 \mathrm{c}+(03\end{array}$

\section{Alkulinity}

$\begin{array}{ll}\mathrm{pH} & \\ \mathrm{OH}^{2} & (\underline{M}) \\ \mathrm{CO}_{3}{ }^{2} & (\underline{M}) \\ \mathrm{HCO}_{3} & (\underline{M})\end{array}$$$
-\quad 12.5
$$$$
\text { - } \quad 0.06
$$$$
-\quad<0.01
$$$$
-\quad<0.01
$$

\section{Beta/gamma cmilters}

\begin{tabular}{|c|c|c|c|}
\hline Gross alpha & $(\mathrm{Bc} / \mathrm{mL}$ ) & $2.71 \mathrm{c}+01$ & $2 .()(\mathrm{c}+1+())$ \\
\hline Gross bela & $(\mathrm{Bc} / \mathrm{mL})$ & $3.21 \mathrm{c}+0.5$ & $3.92 \mathrm{c}+.15$ \\
\hline${ }^{14} \mathrm{C}$ & $(\mathrm{Bc} / \mathrm{mL})$ & $3.29 \mathrm{c}+(1) 2$ & - \\
\hline${ }^{1 / 4} \mathrm{Ce}$ & $(\mathrm{Br}, / \mathrm{mL})$ & . & $<1.3 \mathrm{e}+0.3$ \\
\hline${ }^{6,1} \mathrm{Co}$ & $(\mathrm{Bq} / \mathrm{mL})$ & $1.84 \mathrm{c}+03$ & $1.88 \mathrm{c}+(1) 3$ \\
\hline${ }^{1.44} \mathrm{Cs}$ & $(\mathrm{Bq} / \mathrm{mL})$ & 3.6()$c+03$ & $3.77 c+0.3$ \\
\hline${ }^{137} \mathrm{Cs}$ & $(\mathrm{Bq} / \mathrm{mL})$. & $3.26 c+05$ & $3.27 \mathrm{c}+105$ \\
\hline${ }^{152} \mathrm{Eu}$ & $(\mathrm{B}(\mathrm{g} / \mathrm{mL})$ & - & $<1.6 c+02$ \\
\hline${ }^{15.4} \mathrm{Eu}$ & $\left(\mathrm{Bc} / \mathrm{mL}_{-}\right)$ & - & $<1.2 \mathrm{e}+(12$ \\
\hline${ }^{155} \mathrm{Eu}$ & $(\mathrm{Bc} / \mathrm{mL})$ & - & $<6.9 c+(12$ \\
\hline${ }^{3} \mathrm{H}$ & $(\mathrm{Bq} / \mathrm{mL})$ & $3.45 c+\left(12^{i}\right.$ & - \\
\hline${ }^{95} \mathrm{~N} / \mathrm{b}$ & $(\mathrm{Bq} / \mathrm{mL})$ & - & $<6.3 c+01$ \\
\hline$\left|x_{1}\right| R u$ & $(\mathrm{Bc} / \mathrm{mL})$ & - & $<1.9 \mathrm{c}+03$ \\
\hline${ }^{*} \mathrm{Sr}$ & $(\mathrm{B}(\mathrm{p} / \mathrm{mL})$ & $1.95 c+(04$ & $1.94 c+(14$ \\
\hline${ }^{9 s} \mathrm{Zr}$ & $(\mathrm{B}(\mathrm{g} / \mathrm{mL})$ & . & $<1.2 \mathrm{e}+() 2$ \\
\hline
\end{tabular}

"Tritium determined on sample W25-L1. 
Physical propertics and miscellencous data

TDS
TS

Density

IC

$\mathrm{TC}$

TOC
369

366

1.2177

2580

3860

1280

\section{RCRA mctals}

$\mathrm{Ag}$
$\mathrm{As}$
$\mathrm{Ba}$
$\mathrm{Cd}$
$\mathrm{Cr}$
$\mathrm{Hg}$
$\mathrm{Ni}$
$\mathrm{Pb}$
$\mathrm{Sc}$
$\mathrm{Tl}$

$$
(\mathrm{mg} / \mathrm{L})
$$

$(\mathrm{mg} / \mathrm{L})$

$(\mathrm{mg} / \mathrm{L})$

$(\mathrm{mg} / \mathrm{L})$

$(\mathrm{mg} / \mathrm{L})$

$(\mathrm{mg} / \mathrm{L})$

$(\mathrm{mg} / \mathrm{L})$

$(\mathrm{mg} / \mathrm{L})$

$(\mathrm{mg} / \mathrm{L})$

$(\mathrm{mg} / \mathrm{L})$

1.2
$<3.7$
0.20
$4.5^{\natural 1}$
1.8
$<0.08$
8.2
3.2
$<4.7$
$<1.4$

\section{Prosess metals}

\section{Al}

B

$\mathrm{Ca}$

Co

$\mathrm{Fe}$

$\mathrm{K}$

$\mathrm{Mg}$

$\mathrm{Na}$

$\mathrm{Si}$

$\mathrm{Sr}$

Th (color)

U (fluor) $(\mathrm{mg} / \mathrm{L})$

$(\mathrm{mg} / \mathrm{L})$

$(\mathrm{mg} / \mathrm{L})$

$(\mathrm{mg} / \mathrm{L})$

$(\mathrm{mg} / \mathrm{L})$

$(\mathrm{mg} / \mathrm{L})$

$(\mathrm{mg} / \mathrm{L})$

$(\mathrm{mg} / \mathrm{L})$

$(\mathrm{mg} / \mathrm{L})$

$(\mathrm{mg} / \mathrm{L})$

$(\mathrm{mg} / \mathrm{L})$

$(\mathrm{mg} / \mathrm{L})$

$\begin{array}{cr}4.8 & - \\ 3.9 & - \\ 20 & - \\ <0.57 & - \\ <26 & - \\ 51(0)(6)^{b} & - \\ 3.5 & - \\ 68(0)()^{b} & - \\ 11.9 & - \\ <0.74 & - \\ 11300^{\circ} & 10\end{array}$




\section{Anions (analyzed by CPA Lab.)}

$\begin{array}{llc}\text { Chloride } & (\mathrm{mg} / \mathrm{L}) & 3.50 \mathrm{c}+(13 \\ \text { Fluoride } & (\mathrm{mg} / \mathrm{L}) & <5.0 \mathrm{e}+02 \\ \text { Nitrate } & (\mathrm{mg} / \mathrm{L}) & 2.04 \mathrm{c}+05 \\ \text { Phosphate } & (\mathrm{mg} / \mathrm{L}) & <5.0 \mathrm{c}+(03 \\ \text { Sulfate } & (\mathrm{mg} / \mathrm{L}) & <5.0 \mathrm{e}+(13\end{array}$

\section{Alkalinity}

$\begin{array}{lllc}\mathrm{pH} & & - & 11.2 \\ \mathrm{OH} & (\underline{\mathrm{M}}) & - & <0.01 \\ \mathrm{CO}_{3}{ }^{2} & (\underline{M}) & - & 0.20 \\ \mathrm{HCO}_{3} & (\underline{M}) & - & 0.02\end{array}$

\section{Beta/gamma cmitters}

\begin{tabular}{|c|c|c|c|}
\hline Gross alpha & $(\mathrm{Bq} / \mathrm{mL})$ & $1.10 \mathrm{e}+(03$ & $1.03 e+03$ \\
\hline Gross beta & $\left(\mathrm{Bq} / \mathrm{mLL}^{\prime}\right)$ & $2.10 e+06$ & $2.20 \mathrm{e}+06$ \\
\hline${ }^{11} \mathrm{C}$ & $(\mathrm{Bg} / \mathrm{mL})$ & $1.23 \mathrm{c}+(02$ & - \\
\hline${ }^{144} \mathrm{Ce}$ & $(\mathrm{Bq} / \mathrm{mL})$ & - & $<2.3 \mathrm{e}+03$ \\
\hline${ }^{60} \mathrm{Co}$ & $(\mathrm{Bg} / \mathrm{mL})$ & $1.07 e+04$ & $1.22 \mathrm{e}+0$ \\
\hline${ }^{1.4} \mathrm{Cs}$ & $(\mathrm{Bq} / \mathrm{mL})$ & $1.02 \mathrm{e}+04$ & $1.31 \mathrm{e}+(04$ \\
\hline${ }^{137} \mathrm{Cs}$ & $(\mathrm{Bq} / \mathrm{mL})$ & $2.08 \mathrm{e}+(06$ & $2.07 \mathrm{e}+() 6$ \\
\hline${ }^{1.2} \mathrm{Eu}$ & $(\mathrm{Bg} / \mathrm{mL})$ & - & $<2.1 \mathrm{e}+02$ \\
\hline${ }^{1.64} \mathrm{Eu}$ & $(\mathrm{Bg} / \mathrm{mL})$ & & $<2.4 c+02$ \\
\hline${ }^{15} \mathrm{Eu}$ & $(\mathrm{Bq} / \mathrm{mL})$ & - & $<1,2 \mathrm{e}+03$ \\
\hline${ }^{3} \mathrm{H}$ & $(\mathrm{Bq} / \mathrm{mL})$ & $6.18 \mathrm{c}+\left(12^{\mathrm{d}}\right.$ & \\
\hline${ }^{9.5} \mathrm{Nb}$ & $(\mathrm{Bq} / \mathrm{mL})$ & - & $<1.4 \mathrm{c}+(12$ \\
\hline${ }^{1 *} \mathrm{Ru}$ & $(\mathrm{Bg} / \mathrm{mL})$ & . & $<2.8 \mathrm{c}+(0) 3$ \\
\hline${ }^{10} \mathrm{Sr}$ & $(\mathrm{Bq} / \mathrm{mL})$ & $4.90 \mathrm{c}+02$ & $2.51 \mathrm{c}+(02$ \\
\hline${ }^{\circ} \mathrm{Zr}$ & $(\mathrm{Bq} / \mathrm{mL})$ & - & $<2.7 \mathrm{c}+() 2$ \\
\hline
\end{tabular}

Alpha cmitters

\begin{tabular}{lllc}
${ }^{212} \mathrm{U}$ & $(\mathrm{Bq} / \mathrm{mL})$ & - & $3.60 \mathrm{c}+01$ \\
${ }^{2313} \mathrm{U}$ & $(\mathrm{Bq} / \mathrm{mL})$ & - & $9.20 \mathrm{c}+(02$ \\
${ }^{212} \mathrm{U}$ & $(\mathrm{Bq} / \mathrm{mL})$ & - & $1 .(0) \mathrm{c}+(01$ \\
${ }^{218} \mathrm{Pu} /{ }^{241} \mathrm{Am}$ & $(\mathrm{Bq} / \mathrm{mL})$ & - & $<1.5 \mathrm{c}+(01$ \\
${ }^{219} \mathrm{Pu} /{ }^{240} \mathrm{Pu}$ & $(\mathrm{Bq} / \mathrm{mL})$ & - & $1 .(0) \mathrm{c}+01$ \\
\hline
\end{tabular}

"Recheck: $\mathrm{Cd}, 5.0 \mathrm{mg} / \mathrm{L}$. Cd in other samples from same tank: W26-L1, $4.3 \mathrm{mg} / \mathrm{L} ; \mathrm{W} 26-\mathrm{L} .3,4.3$ $\mathrm{mg} / \mathrm{l}$

${ }^{6}$ Recheck: K, 56(0) mg/Li Na, $\left.750(0) 0\right) \mathrm{mg} / \mathrm{L}$.

Uranium was confirmed by other peaks in ICP spectrum.

Tritium was determined on sample W26-L1. 
C. 12

Sample: W27-L2

IPA

TAL

Physical propertics and miscollancous data

$\begin{array}{lll}\text { TDS } & (\mathrm{mg} / \mathrm{mL}) & 358 \\ \text { TS } & (\mathrm{mg} / \mathrm{mL}) & 355\end{array}$

Density $\quad(\mathrm{g} / \mathrm{mL}) \quad 1.2118$

$\begin{array}{lll}\text { IC } & (\mathrm{mg} / \mathrm{L})^{\prime} & 4.7\end{array}$

TC $\quad(\mathrm{mg} / \mathrm{L}) \quad 364$

TOC $\quad(\mathrm{mg} / \mathrm{L}) \quad 359$

RCRA motals

$\begin{array}{lll}\mathrm{Ag} & (\mathrm{mg} / \mathrm{L}) & <0.69 \\ \mathrm{As} & (\mathrm{mg} / \mathrm{L}) & <3.7 \\ \mathrm{Ba} & (\mathrm{mg} / \mathrm{L}) & 4.1 \\ \mathrm{Cd} & (\mathrm{mg} / \mathrm{L}) & 0.12 \\ \mathrm{Cr} & (\mathrm{mg} / \mathrm{L}) & 2.8 \\ \mathrm{Hg} & (\mathrm{mg} / \mathrm{L}) & <0.048 \\ \mathrm{Ni} & (\mathrm{mg} / \mathrm{L}) & <0.38 \\ \mathrm{~Pb} & (\mathrm{mg} / \mathrm{L}) & <2.1 \\ \mathrm{Se} & (\mathrm{mg} / \mathrm{L}) & <4.7 \\ \mathrm{Tl} & (\mathrm{mg} / \mathrm{L}) & <1.4\end{array}$

\section{Process metals}

$\begin{array}{lcc}\mathrm{Al} & (\mathrm{mg} / \mathrm{L}) & <4.2 \\ \mathrm{~B} & (\mathrm{mg} / \mathrm{L}) & 0.67 \\ \mathrm{Ca} & (\mathrm{mg} / \mathrm{L}) & 2600 \\ \mathrm{Co} & (\mathrm{mg} / \mathrm{L}) & <0.57 \\ \mathrm{Fe} & (\mathrm{mg} / \mathrm{L}) & <2.6 \\ \mathrm{~K} & (\mathrm{mg} / \mathrm{L}) & 8500 \\ \mathrm{Mg} & (\mathrm{mg} / \mathrm{L}) & <1.3 \\ \mathrm{Na} & (\mathrm{mg} / \mathrm{L}) & 9(0)(0) \\ \mathrm{Si} \text { (color) } & (\mathrm{mg} / \mathrm{L}) & <1.0 \\ \mathrm{Sr} & (\mathrm{mg} / \mathrm{L}) & 18 \\ \mathrm{Th} \text { (ICP) } & (\mathrm{mg} / \mathrm{L}) & <2.2 \\ \mathrm{U} \text { (fluor) } & (\mathrm{mg} / \mathrm{L}) & <0.1\end{array}$




\section{C-13}

Sample: W27-L2

IPA

TAL

Anions (analyzed by CPA Lab.)

Chloride

$(\mathrm{mg} / \mathrm{L})$

Fluoride

$(\mathrm{mg} / \mathrm{L})$

Nitrate

$(\mathrm{mg} / \mathrm{L})$

Phosphate $(\mathrm{mg} / \mathrm{L})$

Sulfate

(mg/L)

$\begin{aligned} & 2.50 \mathrm{e}+03 \\ < & 5.0 \mathrm{e}+02 \\ & 2.80 \mathrm{e}+05 \\ < & 5.0 \mathrm{e}+03 \\ < & 5.0 \mathrm{e}+03\end{aligned}$

$-$

-

$-$

$-$

\section{Alkalinity}

$\mathrm{pH}$

$\mathrm{OH}^{-}$

(ㅆ)

$\mathrm{CO}_{3}^{2}$

$(\underline{\mathrm{M}})$

$\mathrm{HCO}_{3}$

(I)

$\begin{array}{cc}- & 11.8 \\ - & 0.01 \\ - & <0.01 \\ - & <0.01\end{array}$

\section{Beta/gamma emitters}

Gross alpha
Gross beta
${ }^{14} \mathrm{C}$
${ }^{144} \mathrm{Ce}$
${ }^{60} \mathrm{Co}$
${ }^{134} \mathrm{Cs}$
${ }^{137} \mathrm{Cs}$
${ }^{152} \mathrm{Eu}$
${ }^{154} \mathrm{Eu}$
${ }^{155} \mathrm{Eu}$
${ }^{3} \mathrm{H}$
${ }^{95} \mathrm{Nb}$
${ }^{106} \mathrm{Ru}$
${ }^{90} \mathrm{Sr}$
${ }^{95} \mathrm{Zr}$

$(\mathrm{Bq} / \mathrm{mL})$

$(\mathrm{Bq} / \mathrm{mL})$

$1.89 \mathrm{e}+01$

$3.02 \mathrm{e}+05$

$1.81 \mathrm{e}+02$

(Bq/mL)

(Bq/mL)

$-$

$2.53 \mathrm{e}+02$

$(\mathrm{Bq} / \mathrm{mL})$

$1.51 \mathrm{e}+03$

$(\mathrm{Bq} / \mathrm{mL})$

$2.18 \mathrm{e}+05$

$<1.0 \mathrm{e}+00$

$(\mathrm{Bq} / \mathrm{mL})$

$(\mathrm{Bq} / \mathrm{mL})$

(Bq/mL)

$(\mathrm{Bq} / \mathrm{mL})$

-

$3.30 \mathrm{e}+05$

$(\mathrm{Bq} / \mathrm{mL})$

(Bq/mL)

(Bq/mL)

$-$

$-$

$2.09 \mathrm{e}+02^{\mathrm{a}}$

$-$

$<7.5 \mathrm{e}+02$

$3.09 \mathrm{e}+02$

$1.61 \mathrm{e}+03$

$2.16 \mathrm{e}+05$

$<1.1 \mathrm{e}+02$

$<6.6 \mathrm{e}+01$

$<4.0 \mathrm{e}+02$

$(\mathrm{Bq} / \mathrm{mL})$

$5.57 \mathrm{e}+04$

$<3.0 \mathrm{e}+01$

$<1.1 \mathrm{e}+03$

$5.24 \mathrm{e}+04$

$<5.2 \mathrm{e}+01$

\footnotetext{
${ }^{a}$ Tritium determined on sample W27-L1.
} 
C-14

Sample: W28-L2

IPA

TAL

Physical propertics and miscellaneous data

$\begin{array}{lll}\text { TDS } & (\mathrm{mg} / \mathrm{mL}) & 485 \\ \text { TS } & (\mathrm{mg} / \mathrm{mL}) & 478\end{array}$

Density $\quad(\mathrm{g} / \mathrm{mL}) \quad 1.2852$

$\begin{array}{lll}\text { IC } & (\mathrm{mg} / \mathrm{L}) & 7.0\end{array}$

TC $\quad(\mathrm{mg} / \mathrm{L}) \quad 581$

TOC $\quad(\mathrm{mg} / \mathrm{L}) \quad 574$

$\underline{\text { RCRA metals }}$

\begin{tabular}{|c|c|c|}
\hline $\mathrm{Ag}$ & $(\mathrm{mg} / \mathrm{L})$ & $<0.69$ \\
\hline As & $(\mathrm{mg} / \mathrm{L})$ & $<3.7$ \\
\hline $\mathrm{Ba}$ & $(\mathrm{mg} / \mathrm{L})$ & 5.8 \\
\hline $\mathrm{Cd}$ & $(\mathrm{mg} / \mathrm{L})$ & 0.51 \\
\hline $\mathrm{Cr}$ & $(\mathrm{mg} / \mathrm{L})$ & 0.38 \\
\hline $\mathrm{Hg}$ & $(\mathrm{mg} / \mathrm{L})$ & 0.14 \\
\hline $\mathrm{Ni}$ & $(\mathrm{mg} / \mathrm{L})$ & 1.4 \\
\hline $\mathrm{Pb}$ & $(\mathrm{mg} / \mathrm{L})$ & $<2.1$ \\
\hline $\mathrm{Se}$ & $(\mathrm{mg} / \mathrm{L})$ & $=4.7$ \\
\hline $\mathrm{Tl}$ & $(\mathrm{mg} / \mathrm{L})$ & $<1.4$ \\
\hline
\end{tabular}

\section{Process metals}

$\begin{array}{lcc}\mathrm{Al} & (\mathrm{mg} / \mathrm{L}) & 5.2 \\ \mathrm{~B} & (\mathrm{mg} / \mathrm{L}) & 0.35 \\ \mathrm{Ca} & (\mathrm{mg} / \mathrm{L}) & 7800 \\ \mathrm{Co} & (\mathrm{mg} / \mathrm{L}) & <0.57 \\ \mathrm{Fe} & (\mathrm{mg} / \mathrm{L}) & <2.6 \\ \mathrm{~K} & (\mathrm{mg} / \mathrm{L}) & 26000 \\ \mathrm{Mg} & (\mathrm{mg} / \mathrm{L}) & 1600 \\ \mathrm{Na} & (\mathrm{mg} / \mathrm{L}) & 96000 \\ \mathrm{Si} \text { (color) } & (\mathrm{mg} / \mathrm{L}) & <1.0 \\ \mathrm{Sr} & (\mathrm{mg} / \mathrm{L}) & 65 \\ \mathrm{Th} \text { (ICP) } & (\mathrm{mg} / \mathrm{L}) & <2.2 \\ \mathrm{U} \text { (fluor) } & (\mathrm{mg} / \mathrm{L}) & <0.10\end{array}$




\section{C-15}

Sample: W28-L2

IPA

TAL

Anions (analyzed by CPA Lab.)

$\begin{array}{llr}\text { Chloric } & (\mathrm{mg} / \mathrm{L}) & 4.80 \mathrm{e}+03 \\ \text { Fluoride } & (\mathrm{mg} / \mathrm{L}) & <5.0 \mathrm{e}+02 \\ \text { Nitrate } & (\mathrm{mg} / \mathrm{L}) & 3.70 \mathrm{e}+05 \\ \text { Phosphate } & (\mathrm{mg} / \mathrm{L}) & <5.0 \mathrm{e}+03 \\ \text { Sulfate } & (\mathrm{mg} / \mathrm{L}) & <5.0 \mathrm{e}+03\end{array}$

Alkalinity

$\begin{array}{lllc}\mathrm{pH} & & - & 9.1 \\ \mathrm{OH}^{-} & (\underline{M}) & - & <0.01 \\ \mathrm{CO}_{3}^{2 \cdot} & (\underline{M}) & - & <0.01 \\ \mathrm{HCO}_{3}{ }^{2} & (\underline{M}) & - & <0.01\end{array}$

Beta/garnma emitters

$\begin{array}{lllc}\text { Gross alpha } & (\mathrm{Bq} / \mathrm{mL}) & 2.14 \mathrm{e}+02 & 4.40 \mathrm{e}+01 \\ \text { Gross beta } & (\mathrm{Bq} / \mathrm{mL}) & 9.35 \mathrm{e}+05 & 9.80 \mathrm{e}+05 \\ { }^{14} \mathrm{C} & (\mathrm{Bq} / \mathrm{mL}) & 1.67 \mathrm{e}+02 & - \\ { }^{144} \mathrm{Ce} & (\mathrm{Bq} / \mathrm{mL}) & - & <1.8 \mathrm{e}+03 \\ { }^{60} \mathrm{Co} & (\mathrm{Bq} / \mathrm{mL}) & 8.64 \mathrm{e}+03 & 8.72 \mathrm{e}+03 \\ { }^{134} \mathrm{Cs} & (\mathrm{Bq} / \mathrm{mL}) & 1.08 \mathrm{e}+04 & 1.06 \mathrm{e}+04 \\ { }^{137} \mathrm{Cs} & \mathrm{Bq} / \mathrm{mL}) & 5.85 \mathrm{e}+05 & 5.66 \mathrm{e}+05 \\ { }^{152} \mathrm{Eu} & (\mathrm{Bq} / \mathrm{mL}) & - & 1.67 \mathrm{e}+03 \\ { }^{154} \mathrm{Eu} & (\mathrm{Bq} / \mathrm{mL}) & - & 7.37 \mathrm{e}+02 \\ { }^{155} \mathrm{Eu} & (\mathrm{Bq} / \mathrm{mL}) & - & <9.3 \mathrm{c}+02 \\ { }^{3} \mathrm{H} & (\mathrm{Bq} / \mathrm{mL}) & 1.19 \mathrm{e}+02^{\mathrm{a}} & - \\ { }^{95} \mathrm{Nb} & (\mathrm{Bq} / \mathrm{mL}) & - & <1.2 \mathrm{e}+02 \\ { }^{106} \mathrm{Ru} & (\mathrm{Bq} / \mathrm{mL}) & - & 3.02 \mathrm{e}+03 \\ { }^{90} \mathrm{Sr} & (\mathrm{Bq} / \mathrm{mL}) & 1.75 \mathrm{c}+05 & 1.22 \mathrm{e}+05 \\ { }^{95} \mathrm{Zr} & (\mathrm{Bq} / \mathrm{mL}) & - & <2.2 \mathrm{c}+02\end{array}$

${ }^{\mathrm{a}}$ Tritium determined on sample W28-L1. 
Physical propertics and miscellancous data

TDS

TS

Density

IC

TC

TOC

$\begin{array}{ll}(\mathrm{mg} / \mathrm{mL}) & 375 \\ (\mathrm{mg} / \mathrm{mL}) & 377\end{array}$

$(\mathrm{mg} / \mathrm{mL})$

$$
(\mathrm{g} / \mathrm{mL})
$$

$$
\text { (mg/L) }
$$

$(\mathrm{mg} / \mathrm{L})$

$(\mathrm{mg} / \mathrm{L})$
377

\subsection{1}

478

985

507

\section{RCRA metals}

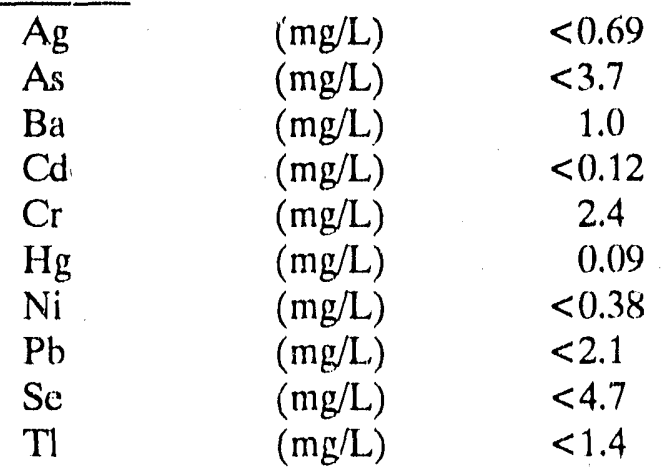

\section{Process metals}

$\begin{array}{lcc}\mathrm{Al} & (\mathrm{mg} / \mathrm{L}) & 18 \\ \mathrm{~B} & (\mathrm{mg} / \mathrm{L}) & 0.50 \\ \mathrm{Ca} & (\mathrm{mg} / \mathrm{L}) & 4.1 \\ \mathrm{Fe} & (\mathrm{mg} / \mathrm{L}) & <2.6 \\ \mathrm{~K} & (\mathrm{mg} / \mathrm{L}) & 10000 \\ \mathrm{Mg} & (\mathrm{mg} / \mathrm{L}) & <1.3 \\ \mathrm{Na} & (\mathrm{mg} / \mathrm{L}) & 110000 \\ \mathrm{Si} & (\mathrm{mg} / \mathrm{L}) & <1 \\ \mathrm{Sr} & (\mathrm{mg} / \mathrm{L}) & 1.9 \\ \mathrm{Th} \text { (color) } & (\mathrm{mg} / \mathrm{L}) & - \\ \mathrm{U} \text { (fluor) } & (\mathrm{mg} / \mathrm{L}) & 4.5\end{array}$




\section{C- 17}

Sumple: W29-L1

IPA

TAL

Anions (analyzed by CPA Lab.)

Chloride

$(\mathrm{mg} / \mathrm{L})$

Fluoride

$(\mathrm{mg} / \mathrm{L})$

Nitrate

(mg/L)

Phosphate

$(\mathrm{mg} / \mathrm{L})$

Sulfate

(mg/L)

$2.9 \mathrm{e}+03$
$<5.0 \mathrm{e}+02$
$2.8 \mathrm{e}+05$
$<5.0 \mathrm{e}+03$
$<5.0 \mathrm{e}+03$

Alkalinity

$\mathrm{pH}$

$\mathrm{OH}$

(M)

$\mathrm{CO}_{3}^{2}$

(M)

$\mathrm{HCO}_{3}$

(프)

12.7

13.0

-

0.064

0.043

$<\quad<0.01$

Beta/gamma cmitters

Gross alpha

Gross beta

${ }^{14} \mathrm{C}$

${ }^{144} \mathrm{Ce}$

${ }^{60} \mathrm{Co}$

${ }^{1.4 .4} \mathrm{Cs}$

${ }^{1.37} \mathrm{Cs}$

${ }^{152} \mathrm{Eu}$

${ }^{154} \mathrm{Eu}$

${ }^{155} \mathrm{Eu}$

${ }^{3} \mathrm{H}$

${ }^{95} \mathrm{Nb}$

${ }^{10 x} \mathrm{Ru}$

${ }^{90} \mathrm{Sr}$

${ }^{95} \mathrm{Zr}$
$(\mathrm{Bq} / \mathrm{mL})$

$(\mathrm{Bq} / \mathrm{mL})$

$(\mathrm{Bq} / \mathrm{mL})$

$(\mathrm{Bq} / \mathrm{mL})$

$(\mathrm{Bq} / \mathrm{mL})$

$(\mathrm{Bq} / \mathrm{mL})$

$(\mathrm{Bq} / \mathrm{mL})$

$(\mathrm{Bq} / \mathrm{mL})$

(Bq/mL)

$(\mathrm{Bq} / \mathrm{mL})$

$(\mathrm{Bq} / \mathrm{mL})$

(Bq/mL)

$(\mathrm{Bq} / \mathrm{mL})$

$(\mathrm{Bq} / \mathrm{mL})$

$(\mathrm{Bq} / \mathrm{mL})$
$8.62 \mathrm{e}+00$

$1.77 \mathrm{e}+05$

$1.43 \mathrm{e}+02$

-

$5.78 \mathrm{c}+02$

$2.43 \mathrm{e}+03$

$2.18 \mathrm{e}+05$

-

$-$

$-$

$2.01 \mathrm{e}+02$

$-$

-

$7.13 e+03$

$7.13 \mathrm{e}+03$

$$
\begin{aligned}
&< 1.0 \mathrm{e}+01 \\
& 2.11 \mathrm{c}+(05 \\
&- \\
&< 1.4 \mathrm{e}+0.3 \\
& 6.44 \mathrm{c}+(02 \\
& 2.51 \mathrm{e}+0.3 \\
& 2.21 \mathrm{e}+05 \\
&< 1.6 \mathrm{c}+02 \\
&<1.5 \mathrm{e}+02 \\
&<7.2 \mathrm{e}+02 \\
&- \\
&<6.4 \mathrm{e}+01 \\
&<2.1 \mathrm{c}+0.3 \\
& 6.98 \mathrm{c}+03 \\
&<9.3 \mathrm{e}+01
\end{aligned}
$$


C.18

Sumple: W29-L2

IPA

TAL

Physical propertics and miscellancous data

TDS

TS

$(\mathrm{mg} / \mathrm{mL}) \quad 376$

$(\mathrm{mg} / \mathrm{mL}) \quad 379$

Density

$(\mathrm{g} / \mathrm{mL})$

1.2277

IC

TC

$(\mathrm{mg} / \mathrm{L})$

$(\mathrm{mg} / \mathrm{L})$

$(\mathrm{mg} / \mathrm{L})$

477

1040

563

RCRA motals

$\mathrm{Ag}$

As

$\mathrm{Ba}$

Cd

$\mathrm{Cr}$

$\mathrm{Hg}$

$\mathrm{Ni}$

$\mathrm{Pb}$.

$\mathrm{Se}$

TI

$\begin{array}{cc}(\mathrm{mg} / \mathrm{L}) & <0.69 \\ (\mathrm{mg} / \mathrm{L}) & <3.7 \\ (\mathrm{mg} / \mathrm{L}) & 1.1 \\ (\mathrm{mg} / \mathrm{L}) & <0.12 \\ (\mathrm{mg} / \mathrm{L}) & 2.4 \\ (\mathrm{mg} / \mathrm{L}) & 0.08 \\ (\mathrm{mg} / \mathrm{L}) & <0.38 \\ (\mathrm{mg} / \mathrm{L}) & <2.1 \\ (\mathrm{mg} / \mathrm{L}) & <4.7 \\ (\mathrm{mg} / \mathrm{L}) & <1.4\end{array}$

\section{Process motals}

$\mathrm{Al}$

B

$\mathrm{Ca}$

$\mathrm{Fe}$

$\mathrm{K}$

$\mathrm{Mg}$

$\mathrm{Na}$

$\mathrm{Si}$

$\mathrm{Sr}$

Th (color)

U (iluor) $(\mathrm{mg} / \mathrm{L})$

$(\mathrm{mg} / \mathrm{L})$

$(\mathrm{mg} / \mathrm{L})$

(mg/L)

(mg/L)

$(\mathrm{mg} / \mathrm{L})$

(mg/L)

(mg/L)

$(\mathrm{mg} / \mathrm{L})$

$(\mathrm{mg} / \mathrm{L})$

$(\mathrm{mg} / \mathrm{L})$

$\begin{array}{cc}18 & - \\ 0.47 & - \\ 5.5 & - \\ <2.6 & - \\ 100(0) & - \\ <1.3 & - \\ 110000) & - \\ <1 & - \\ 2.1 & - \\ - & <1.0 \\ 4.3 & -\end{array}$




\section{Anions (analyzed by CPA Lab.)}

$\begin{array}{llr}\text { Chloride } & (\mathrm{mg} / \mathrm{L}) & 2.8 \mathrm{c}+0.3 \\ \text { Fluoride } & (\mathrm{mg} / \mathrm{L}) & <5 .() \mathrm{c}+02 \\ \text { Nitrate } & (\mathrm{mg} / \mathrm{L}) & 2.8 \mathrm{c}+(05 \\ \text { Phosphate } & (\mathrm{mg} / \mathrm{L}) & <5 .(0 \mathrm{c}+(0) 3 \\ \text { Sulfate } & (\mathrm{mg} / \mathrm{L}) & <5 .(0 \mathrm{c}+(0) 3\end{array}$

Alkalinity

$\begin{array}{lccc}\mathrm{pH} & & 12.8 & 13.0 \\ \mathrm{OH}^{2} & (\underline{\mathrm{M}}) & - & 0.069 \\ \mathrm{CO}_{3}{ }^{2 .} & (\underline{\mathrm{M}}) & - & 0.04 \\ \mathrm{HCO}_{3}{ }^{2} & (\underline{\mathrm{M}}) & - & <0.01\end{array}$

Beta/gamma cmitlers

\begin{tabular}{|c|c|c|c|}
\hline Gross alpha & $(\mathrm{B}(\mathrm{g} / \mathrm{mL})$ & $1.24 \mathrm{c}+01$ & $<1 .() \mathrm{e}+() 1$ \\
\hline Gross beta & $(\mathrm{Bq} / \mathrm{mL})$ & $1.82 \mathrm{e}+05$ & $1.98 \mathrm{c}+0.5$ \\
\hline${ }^{14} \mathrm{C}$ & $(\mathrm{B}(\mathrm{q} / \mathrm{mL})$ & $7.3 c+01$ & - \\
\hline${ }^{144} \mathrm{Ce}$ & $(\mathrm{Bq} / \mathrm{mL})$ & 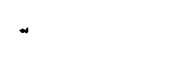 & $<1.3 c+03$ \\
\hline${ }^{n 0} \mathrm{Co}$ & $(\mathrm{Bc} / \mathrm{mL})$ & $6.06 \mathrm{c}+(02$ & $5.99 \mathrm{c}+(12$ \\
\hline${ }^{1.44} \mathrm{CSS}$ & $(\mathrm{Bq} / \mathrm{mL})$ & $2.37 c+0.3$ & $2.57 c+03$ \\
\hline${ }^{137} \mathrm{Cs}$ & $(\mathrm{Bq} / \mathrm{mL})$ & $2.17 e+05$ & $2.22 \mathrm{e}+05$ \\
\hline${ }^{152} \mathrm{Eu}$ & $(\mathrm{Bq} / \mathrm{mL})$ & - & $<2 .() \mathrm{e}+02$ \\
\hline${ }^{154} \mathrm{Eu}$ & $(\mathrm{Bc} / \mathrm{mL})$ & . & $<1.6 \mathrm{c}+() 2$ \\
\hline${ }^{155} \mathrm{Eu}$ & $(\mathrm{Bc} / \mathrm{mL})$ & - & $<7.1 \mathrm{c}+02$ \\
\hline${ }^{3} \mathrm{H}$ & $(\mathrm{Bq} / \mathrm{mL})$ & $2.01 \mathrm{e}+02$ & - \\
\hline${ }^{9 .} \mathrm{Nb}$ & $(\mathrm{Bq} / \mathrm{mL})$ & 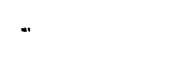 & $<6.2 \mathrm{c}+(01$ \\
\hline${ }^{16 x} \mathrm{Ru}$ & $(\mathrm{Bc} / \mathrm{mL})$ & - & $<2 .() \mathrm{c}+0.3$ \\
\hline${ }^{40} \mathrm{Sr}$ & $(\mathrm{Bc} / \mathrm{mL})$ & $7.0(0)+03$ & $7.08 c+03$ \\
\hline${ }^{95} \mathrm{Zr}$ & $(\mathrm{Bq} / \mathrm{mL})$ & - & $<1.1 \mathrm{c}+02$ \\
\hline
\end{tabular}




\begin{tabular}{|c|c|c|c|}
\hline Sample: W29-L4 & & IPA & TAL \\
\hline \multicolumn{4}{|c|}{ Physical propertics and miscellaneous data } \\
\hline TDS & $(\mathrm{mlg} / \mathrm{mL})$ & 375 & “ \\
\hline TS & $(\mathrm{mg} / \mathrm{mL})$ & 382 & - \\
\hline Density & $(g / m L)$ & 1.2254 & - \\
\hline IC & $(\mathrm{mg} / \mathrm{L})$ & 4.56 & . \\
\hline $\mathrm{TC}$ & $(\mathrm{mg} / \mathrm{L})$ & 8.33 & - \\
\hline $\mathrm{TOC}$ & $(\mathrm{mg} / \mathrm{L})$ & 377 & - \\
\hline
\end{tabular}

\section{RCRA mictuls}

\begin{tabular}{|c|c|c|}
\hline $\mathrm{Ag}$ & $(\mathrm{mg} / \mathrm{L})$ & $<0.69$ \\
\hline As & $(\mathrm{mg} / \mathrm{L})$ & $<3.7$ \\
\hline $\mathrm{Ba}$ & $(\mathrm{mg} / \mathrm{L})$ & 1.0 \\
\hline $\mathrm{Cd}$ & $(\mathrm{mg} / \mathrm{L})$ & $<0,12$ \\
\hline $\mathrm{Cr}$ & $(\mathrm{mg} / \mathrm{L})$ & 2.3 \\
\hline $\mathrm{Hg}$ & $(\mathrm{mg} / \mathrm{L})$ & 0.09 \\
\hline $\mathrm{Ni}$ & $(\mathrm{mg} / \mathrm{L})$ & $<0,38$ \\
\hline $\mathrm{Pb}$ & $(\mathrm{mg} / \mathrm{L})$ & 2.3 \\
\hline $\mathrm{Se}$ & $(\mathrm{mg} / \mathrm{L})$ & $<4.7$ \\
\hline$T$ & $(\mathrm{mg} / \mathrm{L})$ & $<1.4$ \\
\hline
\end{tabular}

Process metals

\begin{tabular}{|c|c|c|c|}
\hline $\mathrm{Al}$ & $(\mathrm{mg} / \mathrm{L})$ & 17 & - \\
\hline$B$ & $(\mathrm{mg} / \mathrm{L})$ & 0.36 & - \\
\hline $\mathrm{Ca}$ & $(\mathrm{mg} / \mathrm{L})$ & 3.6 & " \\
\hline $\mathrm{FC}$ & $(\mathrm{mg} / \mathrm{L})$ & $<2.6$ & - \\
\hline $\mathrm{K}$ & $(\mathrm{mg} / \mathrm{L})$ & $10(0) 00$ & - \\
\hline $\mathrm{Mg}$ & $(\mathrm{mg} / \mathrm{L})$ & $<1.3$ & - \\
\hline $\mathrm{Na}$ & $(\mathrm{mg} / \mathrm{L})$ & $110(0)(0$ & - \\
\hline $\mathrm{Si}$ & $(\mathrm{mg} / \mathrm{L})$ & $<1$ & . \\
\hline $\mathrm{Sr}$ & $(\mathrm{mg} / \mathrm{L})$ & 1.9 & - \\
\hline Th (color) & $(\mathrm{mg} / \mathrm{L})$ & - & $<1.0$ \\
\hline U (lluor) & $(\mathrm{mg} / \mathrm{L})$ & 4.3 & - \\
\hline
\end{tabular}




\section{Anions (anulyead by CPA Lab.)}

Chloride

Fluoride

Nitrute

Phosphate

sullate $(\mathrm{mg} / \mathrm{L})$

$(m g / L)$

$(\mathrm{mg} / \mathrm{L})$

$(\mathrm{mg} / \mathrm{L})$

$(\mathrm{mg} / \mathrm{L}$ )
$2.90+(1.3$

$<5 .(k+1) 2$

$2.80+(0.5$

$5 .(k+1) 3$

$5.0 \mathrm{c}+(), 3$

\section{Alkalinity}

$\mathrm{pH}$

$\mathrm{OH}$

$\mathrm{CO}_{3}{ }^{2+}$

$\mathrm{HCO}_{i}$
(M)

(M)

(M)
12.7

.

.
$13 .()$

0.074

(). 154

$<(),() 1$

\section{Bel.a/gamma cmillors}

\begin{tabular}{|c|c|c|c|}
\hline Gross alpha & $(\mathrm{Bc} / \mathrm{mL})$ & $8.490+(K)$ & $<1,() \mathrm{c}+() 1$ \\
\hline Gross bela & $(\mathrm{Bc} / \mathrm{m} 1 \mathrm{~L})$. & $1.84 c+(25$ & $2.09 c+(1) 5$ \\
\hline${ }^{14} \mathrm{C}$ & $(\mathrm{Bc} / \mathrm{mL})$ & $5.6 x+(0) 1$ & - \\
\hline${ }^{1.4} \mathrm{Cc}$ & $(B \mathrm{~B} / \mathrm{mL})$ & 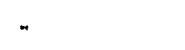 & $<1.3 \mathrm{c}+(1.3$ \\
\hline${ }^{(x)} \mathrm{Cos}$ & $(\mathrm{Bc} / \mathrm{mL})$ & $6.410+(12$ & $6.2(c+1) 2$ \\
\hline${ }^{1.14} \mathrm{Cs}$ & $(\mathrm{Bc} / \mathrm{mL})$ & $2.67 c+0.3$ & $2.5 .3 c+() .3$ \\
\hline $1.31 \mathrm{Cs}$ & $(\mathrm{Bg} / \mathrm{mL})$ & $2.18 \mathrm{c}+(05$ & $2.16 c+(1) 5$ \\
\hline${ }^{152} \mathrm{Eu}$ & $(\mathrm{Bc} / \mathrm{mL})$ & + & $<2.7 \mathrm{c}+() 2$ \\
\hline${ }^{154} \mathrm{Eu}$ & $(\mathrm{Bg} / \mathrm{mL})$ & - & $<1.2 \mathrm{c}+(02$ \\
\hline${ }^{1 S E u}$ & $(\mathrm{Bc} / \mathrm{mL})$ & - & $<7.2 \mathrm{c}+(1) 2$ \\
\hline${ }^{\cdot} \mathrm{H}$ & $(\mathrm{Bg} / \mathrm{mL})$ & $2.010+02$ & - \\
\hline${ }^{95} \mathrm{Nb}$ & $(\mathrm{Bu} / \mathrm{mL})$ & 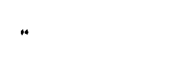 & $<6.3 \mathrm{c}+(1) 2$ \\
\hline$|(x)| R . u$ & $(\mathrm{Bg} / \mathrm{mL} \mathrm{L})$ & - & $<2 .() c+0) .3$ \\
\hline${ }^{x / 1} \mathrm{Sr}$ & $(\mathrm{Bc} / \mathrm{mL})$ & $7.110+(0.3$ & $6.73 c+0.3$ \\
\hline${ }^{45} \mathrm{Zr}$ & $(\mathrm{Bc} / \mathrm{mL})$ & - & $<1,() c+() 2$ \\
\hline
\end{tabular}


Sumple: W3()-L,

IPA

TAL

Physical proportics and miscellaneous data

TDS

TS

Density

IC

TC

TOC $(\mathrm{mg} / \mathrm{mL})$

$(\mathrm{mg} / \mathrm{mL})$

$(\mathrm{g} / \mathrm{mL} \mathrm{L})$

( $\mathrm{mg} / \mathrm{L}$ )

$(\mathrm{mg} / \mathrm{L})$

$(\mathrm{mg} / \mathrm{L})$
371

396

1.222 .5

6(1)

$8(1) 5$

203

\section{RCRA motuls}

$\begin{array}{lccc}\mathrm{Ag} & & (\mathrm{mg} / \mathrm{L}) & <0.69 \\ \mathrm{As} & & (\mathrm{mg} / \mathrm{L}) & <3.7 \\ \mathrm{Ba} & & (\mathrm{mg} / \mathrm{L}) & 0.80 \\ \mathrm{Cl} & & (\mathrm{mg} / \mathrm{L}) & <(1.12 \\ \mathrm{Cr} & & (\mathrm{mg} / \mathrm{L}) & 3.0 \\ \mathrm{Hg} & (\mathrm{mg} / \mathrm{L}) & 0.10 \\ \mathrm{Ni} & (\mathrm{mg} / \mathrm{L}) & <(1.38 \\ \mathrm{Pb} & (\mathrm{mg} / \mathrm{L}) & 3.0 \\ \mathrm{Sc} & (\mathrm{mg} / \mathrm{L}) & <4.7 \\ \mathrm{Tl} & (\mathrm{mg} / \mathrm{L}) & <1.4\end{array}$

\section{Proceass motals}

Al

B

Ca

$\mathrm{Fc}$

$\mathrm{K}$

$\mathrm{Mg}$

$\mathrm{Na}$

$\mathrm{Si}$

$\mathrm{Sr}$

Th (color)

U (fluor)

$(\mathrm{mg} / \mathrm{L})$

( $\mathrm{mg} / \mathrm{L}$ )

$(\mathrm{mg} / \mathrm{L})$

$(\mathrm{mg} / \mathrm{L})$

(mg/L)

$(\mathrm{mg} / \mathrm{L})$

$(\mathrm{mg} / \mathrm{L}$ )

$(\mathrm{mg} / \mathrm{L})$

( $\mathrm{mg} / \mathrm{L}$ )

(mg/L)

$(\mathrm{mg} / \mathrm{L})$

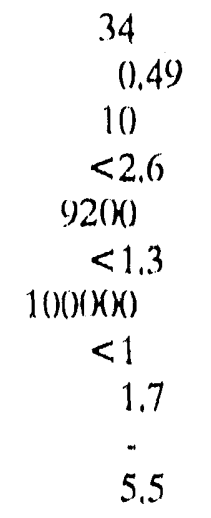


Sumplo: W3().L.1

IPA

T'AL,

Anions (anulyexed by CPA Lub.)

\begin{tabular}{|c|c|c|}
\hline Chiloricle & $(m g / L)$ & $2.8 c+1) .3$ \\
\hline Irluoride & $(m g / L)$ & $<5,(k)+(1) 2$ \\
\hline Nltinle & $(\mathrm{mg} / \mathrm{L})$ & $2.7 c+(15$ \\
\hline Phosphate & (mg/L) & $<5,(k+1), 3$ \\
\hline Sullinte & $(\mathrm{mg} / \mathrm{l})$ & $<5 .(k \mathrm{c}+1), 3$ \\
\hline
\end{tabular}

Alkulinity

$\begin{array}{ll}\text { PH } & \\ \mathrm{OH}^{2} & (\mathrm{M}) \\ \mathrm{CO}_{3}^{2} & (\underline{M}) \\ \mathrm{HCO}_{3} & (\mathrm{M})\end{array}$

12.8

13.2

- $\quad 0.13$

-
.

$-\quad<(),() 1$

Beta/gammu omillors

\begin{tabular}{|c|c|c|c|}
\hline Gross alpha & $(\mathrm{Bc} / \mathrm{mL})$ & $8.36 x+(k)$ & $<1 .() 0+(0)$ \\
\hline Gross bola & $(\mathrm{BC} / \mathrm{mL})$ & $1 .(88 c+1) 5$ & $1.97 c+0.5$ \\
\hline${ }^{11} \mathrm{C}$ & $(\mathrm{BC} / \mathrm{mL})$ & $6.8 \mathrm{c}+01$ & - \\
\hline${ }^{1+1} \mathrm{Cc}$ & $(\mathrm{Bc} / \mathrm{mL})$ & - & $<1.2 c+0.3$ \\
\hline${ }^{(1)} \mathrm{C} \cdot(0)$ & $(B(j / m L)$ & $5 .(1)+(1) 2$ & $4.93 c+112$ \\
\hline${ }^{11} \mathrm{Cr}$ & $(\mathrm{Bc} / \mathrm{mL})$ & $1.82 \mathrm{c}+(0.3$ & $2.0 .5 c+0.3$ \\
\hline${ }^{1.17} \mathrm{Css}$ & $(\mathrm{Bc} / \mathrm{mL})$ & $1.95 c+1.5$ & $1.86 x+0.5$ \\
\hline${ }^{12 \mathrm{EU}}$ & $(\mathrm{B}(\mathrm{j} / \mathrm{mL})$. & - & $<1.7 \mathrm{c}+(1) 2$ \\
\hline${ }^{15.4} \mathrm{Eu}$ & $(B(j / m L)$ & . & $<1.5 \mathrm{c}+() 2$ \\
\hline${ }^{19} \mathrm{EU}$ & $(B(j / m L)$ & . & $<6.7 \mathrm{c}+(1) 2$ \\
\hline${ }^{3} \mathrm{H}$ & $(\mathrm{Bc} / \mathrm{mL})$. & $2 .(14 c+(1) 2$ & - \\
\hline${ }^{45} \mathrm{Nb}$ & $(\mathrm{Bc} / \mathrm{mL})$ & - & $<5.10+() 1$ \\
\hline${ }^{10 x} \mathrm{R} \cdot \mathrm{Ru}$ & $\left(B\left(p^{\prime} m L\right)\right.$ & " & $<1.9 c+(0.3$ \\
\hline${ }^{4} \mathrm{SI}$ & $(\mathrm{Bc} / \mathrm{mL})$ & $6.75 c+(13$ & $0.24 c+(0.3$ \\
\hline${ }^{4} \mathrm{Zr}$ & $(B(j / m L)$ & - & $<9.5 c+(0) 1$ \\
\hline
\end{tabular}


Simple: W.3(1) 1.2

IPA

'T'AL,

Physical proportices and misecollancous data

$\begin{array}{lll}\text { TDS } & (\mathrm{mg} / \mathrm{mL}) & 377 \\ \text { TS } & (\mathrm{mg} / \mathrm{mL}) & 391\end{array}$

Densily $\quad(\mathrm{g} / \mathrm{mL}) \quad 1.2218$

IC $\quad(\mathrm{mg} / \mathrm{L}) \quad 596$

'T'C (mg/L) $\quad 695$

TOC $\quad(\mathrm{mg} / \mathrm{L}) \quad 99$

RCRA motuls

$\begin{array}{ccc}\mathrm{Ag} & (\mathrm{mg} / \mathrm{L}) & <0.60 \\ \mathrm{As} & (\mathrm{mg} / \mathrm{L}) & <3.7 \\ \mathrm{Ba} & (\mathrm{mg} / \mathrm{L}) & 0.84 \\ \mathrm{Cd} & (\mathrm{mg} / \mathrm{L}) & <0.12 \\ \mathrm{Cr} & (\mathrm{mg} / \mathrm{L}) & 2.9 \\ \mathrm{Hg} & (\mathrm{mg} / \mathrm{L}) & 0.10 \\ \mathrm{NI} & (\mathrm{mg} / \mathrm{L}) & <0.38 \\ \mathrm{~Pb} & (\mathrm{mg} / \mathrm{L}) & 2.9 \\ \mathrm{Sc} & (\mathrm{mg} / \mathrm{L}) & <4.7 \\ \mathrm{Tl} & (\mathrm{mg} / \mathrm{L}) & <1.4\end{array}$

Process molals

Al

B

$(\mathrm{mg} / \mathrm{L}$.

3.3

$(n g / L)$

0.42

$\left(m g / L_{-1}\right)$

9.4

lic

(mg/L)

$<2.6$

K

(mg/L)

$93(k)$

$\mathrm{Mg}$

$\mathrm{Na}$

(mg/L.)

$<1.3$

$\mathrm{Si}$

$\mathrm{Sr}$

$(\mathrm{mg} / \mathrm{L})$

$(\mathrm{mg} / \mathrm{l}$ )

$(\mathrm{mg} / \mathrm{L})$

()()(x)(x)

Th (color) (mg/L)

$<1$

U (lluor)

$(\mathrm{mg} / \mathrm{L})$

1.8

$*$

5.8

$<1,0$ 
C.25

TAL.

\section{Anions (analyead by CPA Lab.)}

Chloride

Fluorido

$(\mathrm{mg} / \mathrm{L})$

$(\mathrm{mg} / \mathrm{L})$

Nitrate

$(\mathrm{mg} / \mathrm{L})$

Phosphate

$(\mathrm{mg} / \mathrm{L})$

Sulfure

$(m g / L)$

$2.9 \mathrm{c}+0.3$
$<5 .(\mathrm{c}+() 2$
$2.7 \mathrm{c}+(0.5$
$<5 .(\mathrm{c}+0) .3$
$<5 .(\mathrm{k}+0) .3$

Alkulinity

$\begin{array}{ll}\mathrm{pH} & \\ \mathrm{OH}^{\circ} & (\underline{\mathrm{M}}) \\ \mathrm{CO}^{2} & \\ \mathrm{HCO}_{3} & (\underline{\mathrm{M}})\end{array}$

12.9

13.3

$\begin{array}{cc}- & 0.13 \\ - & 0.052 \\ \therefore & <0 .(01\end{array}$

Beta/gamma omilters

\begin{tabular}{|c|c|c|c|}
\hline Gross alpha & $(\mathrm{Bg} / \mathrm{mL})$ & $7.76 \mathrm{c}+00)$ & $<1 .() \mathrm{c}+(-1) 1$ \\
\hline Gross bela & $(\mathrm{Bq} / \mathrm{mL})$ & $1.9(x+05$ & $1.93 c+(05$ \\
\hline${ }^{11} \mathrm{C}$ & $(\mathrm{Bq} / \mathrm{mL})$ & $8.6 \mathrm{c}+01$ & 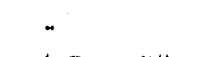 \\
\hline${ }^{1}{ }^{\prime} \mathrm{Ca}$ & $(\mathrm{Bq} / \mathrm{mL})$ & - & $<1.2 c+03$ \\
\hline${ }^{(1)} \mathrm{Co}$ & $\left(\mathrm{Bq} / \mathrm{ml}^{\prime}\right)$ & $4.04 c+() 2$ & $4.8 .3 \mathrm{c}+(12$ \\
\hline${ }^{1.94} \mathrm{Cs}$ & $(\mathrm{Bq} / \mathrm{mL})$ & $2.02 \mathrm{e}+0.3$ & $2.03 c+(1) 3$ \\
\hline${ }^{1.97} \mathrm{Cs}$ & $(\mathrm{Bc} / \mathrm{mL})$ & $1.9(x+0) 5$ & $1.87 c+05$ \\
\hline${ }^{152} \mathrm{Eu}$ & $(\mathrm{Bc} / \mathrm{mL})$ & - & $<2.2 \mathrm{e}+(1) 2$ \\
\hline${ }^{154} \mathrm{EU}$ & $(\mathrm{Bq} / \mathrm{mL})$ & . & $<1.1 c+(12$ \\
\hline${ }^{155} \mathrm{Eu}$ & $(\mathrm{Bc} / \mathrm{mL})$ & - & $<6,6 c+() 2$ \\
\hline 'H & $(\mathrm{Bq} / \mathrm{mL})$ & $2 .(0) 1 \mathrm{c}+() 2$ & $"$ \\
\hline${ }^{9 !} \mathrm{Nb}$ & $(\mathrm{Bq} / \mathrm{mL})$ & " & $<5.5 c+(01$ \\
\hline${ }^{\prime \prime x_{1}} \mathrm{Ru}$ & $(\mathrm{Bc} / \mathrm{mL})$ & $\cdot$ & $<1.9 \mathrm{c}+(03$ \\
\hline${ }^{*} \mathrm{Sr}$ & $(\mathrm{Bq} / \mathrm{mL})$ & $6.70) e+(03$ & $6.55 c+03$ \\
\hline${ }^{95} \mathrm{Zr}$ & $(B c / m L)$ & - & $<1.10+(1) 2$ \\
\hline
\end{tabular}


Sumple: W3()-L4

IPA

T'AL

Physical properticy and misccellancous data

TDS

TS

$(\mathrm{mg} / \mathrm{mL})$

$(\mathrm{mg} / \mathrm{mL})$

$\left(\mathrm{g} / \mathrm{mL}_{-}\right)$

$(\mathrm{mg} / \mathrm{L})$

$(\mathrm{mg} / \mathrm{L})$

(mg/L)

IC

TC

TOC

Density

1.2211

600

799

199

\section{RCRA mctals}

\begin{tabular}{|c|c|c|}
\hline $\mathrm{Ag}$ & $(\mathrm{mg} / \mathrm{L})$ & $<0.69$ \\
\hline As & $(\mathrm{mg} / \mathrm{L})$ & $<3.7$ \\
\hline $\mathrm{Ba}$ & $(\mathrm{mg} / \mathrm{L})$ & 0.79 \\
\hline $\mathrm{Cd}$ & $(\mathrm{mg} / \mathrm{L})$ & $<0.12$ \\
\hline $\mathrm{Cr}$ & $(\mathrm{mg} / \mathrm{L})$ & 2.9 \\
\hline $\mathrm{Hg}$ & $(\mathrm{mg} / \mathrm{L})$ & 0.10 \\
\hline $\mathrm{Ni}$ & $(\mathrm{mg} / \mathrm{L})$ & $<0,38$ \\
\hline $\mathrm{Pb}$ & $(\mathrm{mg} / \mathrm{L})$ & 2.3 \\
\hline $\mathrm{Se}$ & $\left(\mathrm{mg} / \mathrm{L}_{1}\right)$ & $<4.7$ \\
\hline $\mathrm{Tl}$ & $(\mathrm{mg} / \mathrm{L})$. & $<1.4$ \\
\hline
\end{tabular}

\section{Process melals}

$\begin{array}{lccc}\mathrm{Al} & (\mathrm{mg} / \mathrm{L}) & 34 & - \\ \mathrm{B} & (\mathrm{mg} / \mathrm{L}) & 0.42 & - \\ \mathrm{Ca} & (\mathrm{mg} / \mathrm{L}) & 11 & - \\ \mathrm{Fc} & (\mathrm{mg} / \mathrm{L}) & <2.6 & - \\ \mathrm{K} & (\mathrm{mg} / \mathrm{L}) & 94(0) & - \\ \mathrm{Mg} & (\mathrm{mg} / \mathrm{L}) & <1.3 & - \\ \mathrm{Na} & (\mathrm{mg} / \mathrm{L}) & 110(0)(0) & - \\ \mathrm{Si} & (\mathrm{mg} / \mathrm{L}) & <1 & - \\ \mathrm{jr} & (\mathrm{mg} / \mathrm{L}) & 1.9 & - \\ \mathrm{Th} \text { (color) } & (\mathrm{mg} / \mathrm{L}) & - & <1.0 \\ \mathrm{U} \text { (fluor) } & (\mathrm{mg} / \mathrm{L}) & 5.9 & -\end{array}$




\section{Sample: W30-L4 \\ Aniors (analyzed by CPA Lab.)}

IPA

TAL

$\begin{array}{llr}\text { Chloride } & (\mathrm{mg} / \mathrm{L}) & 2.8 \mathrm{e}+03 \\ \text { Fluoride } & (\mathrm{mg} / \mathrm{L}) & <5.0 \mathrm{e}+02 \\ \text { Nitrate } & (\mathrm{mg} / \mathrm{L}) & 2.7 \mathrm{e}+05 \\ \text { Phosphate } & (\mathrm{mg} / \mathrm{L}) & <5.0 \mathrm{e}+03 \\ \text { Sulfate } & (\mathrm{mg} / \mathrm{L}) & <5.0 \mathrm{e}+03\end{array}$

Alks linity

$\begin{array}{ll}\mathrm{pH} & (\underline{\mathrm{M}}) \\ \mathrm{OH}^{-} & (\underline{\mathrm{M}}) \\ \mathrm{CO}_{3}^{2} & (\underline{\mathrm{M}})\end{array}$

12.8

13.3

-

0.13

$-\quad 0.052$
$-\quad 0.01$

$<0.01$

Beta/gamma emitters

$\begin{array}{lllc}\text { Gross alpha } & (\mathrm{Bq} / \mathrm{mL}) & 7.17 \mathrm{e}+00 & <1.0 \mathrm{e}+01 \\ \text { Gross beta } & (\mathrm{Bq} / \mathrm{mL}) & 1.84 \mathrm{e}+05 & 1.92 \mathrm{e}+05 \\ { }^{14} \mathrm{C} & (\mathrm{Bq} / \mathrm{mL}) & 1.10 \mathrm{e}+02 & - \\ { }^{144} \mathrm{Ce} & (\mathrm{Bq} / \mathrm{mL}) & - & <1.3 \mathrm{e}+03 \\ { }^{60} \mathrm{Co} & (\mathrm{Bq} / \mathrm{mL}) & 4.78 \mathrm{e}+02 & 4.91 \mathrm{e}+02 \\ { }^{134} \mathrm{Cs} & (\mathrm{Bq} / \mathrm{mL}) & 1.99 \mathrm{e}+03 & 1.96 \mathrm{e}+03 \\ { }^{1.17} \mathrm{Cs} & (\mathrm{Bq} / \mathrm{mL}) & 1.89 \mathrm{e}+05 & 1.90 \mathrm{e}+05 \\ { }^{152} \mathrm{Eu} & (\mathrm{Bq} / \mathrm{mL}) & - & <2.1 \mathrm{e}+02 \\ { }^{154} \mathrm{Eu} & (\mathrm{Bq} / \mathrm{mL}) & - & <1.0 \mathrm{e}+02 \\ { }^{155} \mathrm{Eu} & (\mathrm{Bq} / \mathrm{mL}) & - & <6.6 \mathrm{e}+02 \\ { }^{3} \mathrm{H} & (\mathrm{Bq} / \mathrm{mL}) & 2.01 \mathrm{e}+02 & - \\ { }^{95} \mathrm{Nb} & (\mathrm{Bq} / \mathrm{mL}) & - & <5.8 \mathrm{e}+01 \\ { }^{106} \mathrm{Ru} & (\mathrm{Bq} / \mathrm{mL}) & - & <1.9 \mathrm{e}+03 \\ { }^{90} \mathrm{Sr} & (\mathrm{Bq} / \mathrm{mL}) & 6.70 \mathrm{e}+03 & 6.57 \mathrm{e}+03 \\ { }^{95} \mathrm{Zr} & (\mathrm{Bq} / \mathrm{mL}) & - & <9.3 \mathrm{e}+01\end{array}$


Physical propertics and miscellaneous data

\section{TDS}

TS

Density

IC.

TC

TOC $(\mathrm{mg} / \mathrm{mL})$

$(\mathrm{mg} / \mathrm{mL})$

$(\mathrm{g} / \mathrm{mL})$

(mg/L)

$(\mathrm{mg} / \mathrm{L})$

(mg/L)
351

349

\subsection{5}

18.9

464

445

\section{$\underline{\text { RCRA metals }}$}

$\mathrm{Ag}$
$\mathrm{As}$
$\mathrm{Ba}$
$\mathrm{Cd}$
$\mathrm{Cr}$
$\mathrm{Hg}$
$\mathrm{Ni}$
$\mathrm{Pb}$
$\mathrm{Se}$
$\mathrm{Tl}$

$$
(\mathrm{mg} / \mathrm{L})
$$

$(\mathrm{mg} / \mathrm{L})$

$(\mathrm{mg} / \mathrm{L})$

$(\mathrm{mg} / \mathrm{L})$

$(\mathrm{mg} / \mathrm{L})$

$(\mathrm{mg} / \mathrm{L})$

$(\mathrm{mg} / \mathrm{L})$

$(\mathrm{mg} / \mathrm{L})$

$(\mathrm{mg} / \mathrm{L})$

(mg/L)

$<0.69$
$<3.7$
3.5
$<0.12$
6.0
0.15
$<0.38$
$<2.1$
$<4.7$
$<1.4$

\section{Process metals}

$\mathrm{Al}$
$\mathrm{B}$
$\mathrm{Ca}$
$\mathrm{Co}$
$\mathrm{Fe}$
$\mathrm{K}$
$\mathrm{Mg}$
$\mathrm{Na}$
$\mathrm{Si}$
$\mathrm{Sr}$

(mg/L)

$(\mathrm{mg} / \mathrm{L})$

(mg/L)

$(\mathrm{mg} / \mathrm{L})$

$(\mathrm{mg} / \mathrm{L})$

$(\mathrm{mg} / \mathrm{L})$

(mg/L)

$(\mathrm{mg} / \mathrm{L})$

(mg/L)

$(\mathrm{mg} / \mathrm{L})$

Th (ICP)

(mg/L)

$\mathrm{U}$ (fluor)

$(\mathrm{mg} / \mathrm{L})$ 


\begin{tabular}{|c|c|c|c|}
\hline Sample: W31-L2 & & IPA & TAL \\
\hline \multicolumn{4}{|c|}{ Anions (analyzed by CPA Lab.) } \\
\hline Chloride & $(\mathrm{mg} / \mathrm{L})$ & $2.60 \mathrm{c}+03$ & - \\
\hline Fluoride & $(\mathrm{mg} / \mathrm{L})$ & $<5.0 \mathrm{c}+02$ & - \\
\hline Nitrate & $(\mathrm{mg} / \mathrm{L})$ & $2.80 \mathrm{e}+05$ & - \\
\hline Phosphate & $(\mathrm{mg} / \mathrm{L})$ & $<5.0 \mathrm{e}+03$ & - \\
\hline Sulfate & $(\mathrm{mg} / \mathrm{L})$ & $<5.0 \mathrm{e}+03$ & - \\
\hline \multicolumn{4}{|l|}{ Alkalinity } \\
\hline $\mathrm{pH}$ & & - & 11.7 \\
\hline $\mathrm{OH}$ & $(\underline{\mathrm{M}})$ & - & 0.01 \\
\hline $\mathrm{CO}_{3}^{2-}$ & $(\underline{\bar{M}})$ & - & $<0.01$ \\
\hline $\mathrm{HCO}_{3}$ & $(\underline{\overline{\mathrm{M}}})$ & - & $<0.01$ \\
\hline \multicolumn{4}{|l|}{ Beta/gamma emitters } \\
\hline Gross alpha & $(\mathrm{Bq} / \mathrm{mL})$ & $1.24 \mathrm{c}+02$ & $<1.0 \mathrm{e}+00$ \\
\hline Gross beta & $(\mathrm{Bq} / \mathrm{mL})$ & $3.47 \mathrm{e}+05$ & $3.58 \mathrm{e}+05$ \\
\hline${ }^{14} \mathrm{C}$ & $(\mathrm{Bq} / \mathrm{mL})$ & $1.12 e+02$ & - \\
\hline${ }^{144} \mathrm{Ce}$ & $(\mathrm{Bq} / \mathrm{mL})$ & - & $<7.8 \mathrm{e}+02$ \\
\hline${ }^{60} \mathrm{Co}$ & $(\mathrm{Bq} / \mathrm{mL})$ & $<2.0 \mathrm{e}+02$ & $3.23 \mathrm{e}+02$ \\
\hline${ }^{134} \mathrm{Cs}$ & $(\mathrm{Bq} / \mathrm{mL})$ & $4.58 \mathrm{e}+03$ & $5.01 \mathrm{e}+03$ \\
\hline${ }^{1.37} \mathrm{Cs}$ & $(\mathrm{Br} / \mathrm{mL})$ & $2.23 \mathrm{e}+05$ & $2.29 e+05$ \\
\hline${ }^{152} \mathrm{Eu}$ & $(\mathrm{Bq} / \mathrm{mL})$ & - & $<9.3 \mathrm{e}+01$ \\
\hline${ }^{154} \mathrm{Eu}$ & $(\mathrm{Bq} / \mathrm{mL})$ & - & $<6.7 e+01$ \\
\hline${ }^{155} \mathrm{Eu}$ & $(\mathrm{Bq} / \mathrm{mL})$ & - & $<4.2 \mathrm{e}+02$ \\
\hline${ }^{3} \mathrm{H}$ & $(\mathrm{Bq} / \mathrm{mL})$ & $1.56 \mathrm{e}+02^{\mathrm{a}}$ & - \\
\hline${ }^{35} \mathrm{Nb}$ & $(\mathrm{Bq} / \mathrm{mL})$ & - & $<3.3 e+01$ \\
\hline${ }^{106} \mathrm{Ru}$ & $(\mathrm{Bq} / \mathrm{mL})$ & - & $<1.1 \mathrm{e}+03$ \\
\hline${ }^{90} \mathrm{Sr}$ & $(\mathrm{Bq} / \mathrm{mL})$ & $7.38 \mathrm{c}+04$ & $6.32 \mathrm{e}+04$ \\
\hline${ }^{95} \mathrm{Zr}$ & $(\mathrm{Bq} / \mathrm{mL})$ & - & $<5.7 \mathrm{e}+01$ \\
\hline
\end{tabular}

${ }^{a}$ Tritium determined on sample W31-L1. 
Physical propertics and miscellancous data

TS

Density

IC

TC

TOC (mg/g)

$(\mathrm{g} / \mathrm{mL})$

1.40

(mg/kg)

$(\mathrm{mg} / \mathrm{kg})$

$(\mathrm{mg} / \mathrm{kg})$

12000

18500

6480

\section{$\underline{\text { RCRA metals }}$}

\begin{tabular}{|c|c|c|}
\hline $\mathrm{Ag}$ & $(\mathrm{mg} / \mathrm{kg})$ & $(50)$ \\
\hline As & $(\mathrm{mg} / \mathrm{kg})$ & (42) \\
\hline $\mathrm{Ba}$ & $(\mathrm{mg} / \mathrm{kg})$ & 78 \\
\hline $\mathrm{Cd}$ & $(\mathrm{mg} / \mathrm{kg})$ & 27 \\
\hline $\mathrm{Cr}$ & $(\mathrm{mg} / \mathrm{kg})$ & 160 \\
\hline $\mathrm{Hg}$ & $(\mathrm{mg} / \mathrm{kg})$ & 56 \\
\hline $\mathrm{Ni}$ & $(\mathrm{mg} / \mathrm{kg})$ & 75 \\
\hline $\mathrm{Pb}$ & $(\mathrm{mg} / \mathrm{kg})$ & 290 \\
\hline $\mathrm{Se}$ & $(\mathrm{mg} / \mathrm{kg})$ & $<25$ \\
\hline $\mathrm{Tl}$ & $(\mathrm{mg} / \mathrm{kg})$ & $<10$ \\
\hline
\end{tabular}

\section{Process metals}

$\begin{array}{llc}\mathrm{Al} & (\mathrm{mg} / \mathrm{kg}) & 1000 \\ \mathrm{~B} & (\mathrm{mg} / \mathrm{kg}) & <6.6 \\ \mathrm{Ca} & (\mathrm{mg} / \mathrm{kg}) & 45000 \\ \mathrm{Cs} & (\mathrm{mg} / \mathrm{kg}) & - \\ \mathrm{Fe} & (\mathrm{mg} / \mathrm{kg}) & 2300 \\ \mathrm{~K} & (\mathrm{mg} / \mathrm{kg}) & 8500 \\ \mathrm{Mg} & (\mathrm{mg} / \mathrm{kg}) & 9600 \\ \mathrm{Na} & (\mathrm{mg} / \mathrm{kg}) & 48000 \\ \mathrm{Sr} & (\mathrm{mg} / \mathrm{kg}) & 200 \\ \mathrm{Th} & (\mathrm{mg} / \mathrm{kg}) & 14000^{\mathrm{a}} \\ \mathrm{U}(\mathrm{ICP}) & (\mathrm{mg} / \mathrm{kg}) & 31000\end{array}$

$<10$ 


\section{C. -31}

Sample: W21-S

IPA

TAL

\section{Beta/gamma cmilters}

$\begin{array}{llll}\text { Gross alpha } & (\mathrm{Bq} / \mathrm{g}) & 1.34 \mathrm{c}+05 & 1.29 \mathrm{e}+05 \\ \text { Gross beta } & (\mathrm{Bq} / \mathrm{g}) & 3.50 \mathrm{c}+06 & 3.36 \mathrm{c}+06 \\ { }^{14} \mathrm{C} & (\mathrm{Bq} / \mathrm{g}) & 1.80 \mathrm{e}+02 & - \\ { }^{144} \mathrm{Ce} & (\mathrm{Bq} / \mathrm{g}) & - & <2.8 \mathrm{c}+04 \\ { }^{60} \mathrm{Co} & (\mathrm{Bq} / \mathrm{g}) & 7.04 \mathrm{c}+04 & 8.07 \mathrm{c}+04 \\ { }^{134} \mathrm{Cs} & (\mathrm{Bq} / \mathrm{g}) & - & 6.99 \mathrm{c}+03 \\ { }^{1.17} \mathrm{Cs} & (\mathrm{Bq} / \mathrm{g}) & 2.28 \mathrm{c}+05 & 2.49 \mathrm{c}+05 \\ { }^{152} \mathrm{Eu} & (\mathrm{Bq} / \mathrm{g}) & 1.30 \mathrm{c}+06 & 1.30 \mathrm{c}+06 \\ { }^{154} \mathrm{Eu} & (\mathrm{Bq} / \mathrm{g}) & 3.93 \mathrm{c}+05 & 4.77 \mathrm{e}+05 \\ { }^{155} \mathrm{Eu} & (\mathrm{Bq} / \mathrm{g}) & 1.17 \mathrm{e}+05 & 1.33 \mathrm{e}+05 \\ { }^{95} \mathrm{Nb} & (\mathrm{Bq} / \mathrm{g}) & - & <4.7 \mathrm{e}+03 \\ { }^{106} \mathrm{Ru} & (\mathrm{Bq} / \mathrm{g}) & - & <4.4 \mathrm{e}+04 \\ { }^{90} \mathrm{Sr} & (\mathrm{Bq} / \mathrm{g}) & 7.52 \mathrm{c}+05 & 7.83 \mathrm{c}+05 \\ { }^{155} \mathrm{Zr} & (\mathrm{Bq} / \mathrm{g}) & - & <3.9 \mathrm{c}+04\end{array}$

Alpha cmitters

${ }^{233} \mathrm{U}$
${ }^{235} \mathrm{U}$
${ }^{239} \mathrm{Pu} /{ }^{240} \mathrm{Pu}$
${ }^{228} \mathrm{Pu} /{ }^{241} \mathrm{Am}$
${ }^{213} \mathrm{Cm}$
${ }^{244} \mathrm{Cm}$

$(\mathrm{Bq} / \mathrm{g})$

$(\mathrm{Bq} / \mathrm{g})$

$(\mathrm{Bq} / \mathrm{g})$

$(\mathrm{Bq} / \mathrm{g})$

$(\mathrm{Bq} / \mathrm{g})$

$(\mathrm{Bq} / \mathrm{g})$

$$
\begin{aligned}
& 8.13 c+(03 \\
< & 2.8 c+04 \\
& 2.49 c+04 \\
5.13 c+04 & <2.5 c+(04 \\
< & 4.46 c+04
\end{aligned}
$$

\footnotetext{
Thorium by ICP.

b Thorium by colorimetric.
} 
Physical propertics and miscellancous data

TS

Density

IC

$\mathrm{TC}$

TOC $(\mathrm{mg} / \mathrm{g})$

$(\mathrm{g} / \mathrm{mL})$

$(\mathrm{mg} / \mathrm{kg})$

$(\mathrm{mg} / \mathrm{kg})$

$(\mathrm{mg} / \mathrm{kg})$
544

1.34

181(K)

222(K)

4120

\section{RCRA molals}

$\begin{array}{lcc}\mathrm{Ag} & (\mathrm{mg} / \mathrm{kg}) & (28) \\ \mathrm{As} & (\mathrm{mg} / \mathrm{kg}) & (<50) \\ \mathrm{Ba} & (\mathrm{mg} / \mathrm{kg}) & 63 \\ \mathrm{Cd} & (\mathrm{mg} / \mathrm{kg}) & 32 \\ \mathrm{Cr} & (\mathrm{mg} / \mathrm{kg}) & 190 \\ \mathrm{Hg} & (\mathrm{mg} / \mathrm{kg}) & 19 \\ \mathrm{Ni} & (\mathrm{mg} / \mathrm{kg}) & 110 \\ \mathrm{~Pb} & (\mathrm{mg} / \mathrm{kg}) & (450) \\ \mathrm{Sc} & (\mathrm{mg} / \mathrm{kg}) & <39 \\ \mathrm{Tl} & (\mathrm{mg} / \mathrm{kg}) & <16\end{array}$

Processs metals

$\mathrm{Al}$

B

$\mathrm{Ca}$

$\mathrm{Cs}$

$\mathrm{Fe}$

$\mathrm{K}$

$\mathrm{Mg}$

$\mathrm{Na}$

$\mathrm{Sr}$

Th

$\mathrm{U}(\mathrm{ICP})$
( $\mathrm{mg} / \mathrm{kg}$ )

$(\mathrm{mg} / \mathrm{kg})$

$(\mathrm{mg} / \mathrm{kg})$

$(\mathrm{mg} / \mathrm{kg})$

$(\mathrm{mg} / \mathrm{kg})$

$(\mathrm{mg} / \mathrm{kg})$

( $\mathrm{mg} / \mathrm{kg})$

(mg/kg)

(mg/kg)

(mg/kg)

$(\mathrm{mg} / \mathrm{kg})$ $28(x)$

$<10$

55()$(x)$

$19(x)$

$18000)$

$160(0)$

82()$(x)$

29()

$130(x)^{a}$

17(0)
3

9)

19

$450)$

39 


\section{Bota/gamma emilters}

\begin{tabular}{|c|c|c|c|}
\hline Gross alpha & $(\mathrm{Bq} / \mathrm{g})$ & $2.23 \mathrm{c}+0.5$ & $2.23 c+(15$ \\
\hline Gross betu & $(\mathrm{Bq} / \mathrm{g})$ & $6.90 \mathrm{c}+(1) 6$ & $6.67 c+06$ \\
\hline${ }^{14} \mathrm{C}$ & $(\mathrm{Bu} / \mathrm{g})$ & $3.65 c+02$ & " \\
\hline${ }^{14} \mathrm{Ce}$ & $(\mathrm{Bq} / \mathrm{g})$ & - & $<2.7 \mathrm{e}+(04$ \\
\hline${ }^{60} \mathrm{Co}$ & $(\mathrm{Bq} / \mathrm{g})$ & $2.41 \mathrm{c}+05$ & $2.52 \mathrm{c}+(1) 5$ \\
\hline $1.34 \mathrm{Cs}$ & $(\mathrm{Bq} / \mathrm{g})$ & - & $<6.5 \mathrm{e}+(0.3$ \\
\hline${ }^{1.37} \mathrm{Cs}$ & $(\mathrm{Bq} / \mathrm{g})$ & $4.81 \mathrm{c}+(05$ & $4.95 c+05$ \\
\hline${ }^{152} \mathrm{Eu}$ & $(\mathrm{Bq} / \mathrm{g})$ & $7.81 \mathrm{c}+05$ & $7.22 \mathrm{e}+(05$ \\
\hline${ }^{154} \mathrm{Eu}$ & $(\mathrm{Bc} / \mathrm{g})$ & $5 .(0) c+0+05$ & $5.14 c+05$ \\
\hline${ }^{15 s} \mathrm{Eu}$ & $(\mathrm{Bq} / \mathrm{g})$ & $1.16 c+05$ & $1.21 \mathrm{e}+(05$ \\
\hline${ }^{95} \mathrm{Nb}$ & $(\mathrm{Bc} / \mathrm{g})$ & - & $<7 .() \mathrm{c}+0.3$ \\
\hline${ }^{I N i} \mathrm{Ru}$ & $(\mathrm{Bc} / \mathrm{g})$ & . & $<6.2 \mathrm{e}+04$ \\
\hline${ }^{2} \mathrm{Sr}$ & $(\mathrm{Bq} / \mathrm{g})$ & $2.28 c+06$ & $2.33 \mathrm{c}+06$ \\
\hline${ }^{95} \mathrm{Zr}$ & $(\mathrm{Bq} / \mathrm{g})$ & 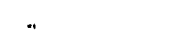 & $<4.50 \div(1) 4$ \\
\hline
\end{tabular}

Alpha emilters

\begin{tabular}{|c|c|c|c|}
\hline${ }^{21 ! 3} \mathrm{U}$ & $(\mathrm{Bc} / \mathrm{g})$ & - & $1.18 \mathrm{c}+() 4$ \\
\hline${ }^{219} \mathrm{U}$ & $(\mathrm{Bq} / \mathrm{g})$ & - & $<2.8 \mathrm{c}+(04$ \\
\hline${ }^{239} \mathrm{Pu} /{ }^{210} \mathrm{Pu}$ & $(\mathrm{Bq} / \mathrm{g})$ & - & $1.18 \mathrm{c}+() 4$ \\
\hline${ }^{218} \mathrm{Pu} /{ }^{211} \mathrm{Am}$ & $(\mathrm{Bq} / \mathrm{g})$ & . & $3.21 \mathrm{c}+(04$ \\
\hline${ }^{243} \mathrm{Cm}$ & $(\mathrm{Bq} / \mathrm{g})$ & - & $<2.6 c+(04$ \\
\hline${ }^{24} \mathrm{Cm}$ & $(B \mathrm{~g} / \mathrm{g})$ & - & $1.67 \mathrm{c}+05$ \\
\hline
\end{tabular}

athorium by ICP.

b Thorium by colorimetric. 
$\frac{\text { Sample: W24-S }}{\text { Physical propertics und miscollancous data }}$

TS $(\mathrm{mg} / \mathrm{g}) \quad 487$

Density $\quad(\mathrm{g} / \mathrm{mL}) \quad 1.26$

IC $\quad(\mathrm{mg} / \mathrm{kg}) \quad 6630$

TC $\quad(\mathrm{mg} / \mathrm{kg}) \quad 9570$

TOC (mg/kg) 2940

\section{RCRA motals}

$\begin{array}{llc}\mathrm{Ag} & (\mathrm{mg} / \mathrm{kg}) & (<7.7) \\ \mathrm{As} & (\mathrm{mg} / \mathrm{kg}) & <42 \\ \mathrm{Ba} & (\mathrm{mg} / \mathrm{kg}) & 44 \\ \mathrm{Cd} & (\mathrm{mg} / \mathrm{kg}) & 6.1 \\ \mathrm{Cr} & (\mathrm{mg} / \mathrm{kg}) & 36 \\ \mathrm{Hg} & (\mathrm{mg} / \mathrm{kg}) & 26 \\ \mathrm{Ni} & (\mathrm{mg} / \mathrm{kg}) & 22 \\ \mathrm{~Pb} & (\mathrm{mg} / \mathrm{kg}) & 150 \\ \mathrm{Sc} & (\mathrm{mg} / \mathrm{kg}) & <52 \\ \mathrm{Tl} & (\mathrm{mg} / \mathrm{kg}) & <16\end{array}$

Process motals

\begin{tabular}{|c|c|c|c|}
\hline $\mathrm{Al}$ & $(\mathrm{mg} / \mathrm{kg})$ & $16(4)$ & - \\
\hline $\mathrm{B}$ & $(\mathrm{mg} / \mathrm{kg})$ & 3.1 & - \\
\hline $\mathrm{Ca}_{\mathrm{a}}$ & $(\mathrm{mg} / \mathrm{kg})$ & $290 \times 10$ & - \\
\hline Cs & $(\mathrm{mg} / \mathrm{kg})$ & $(<1.3)$ & - \\
\hline $\mathrm{Fe}$ & $(\mathrm{mg} / \mathrm{kg})$ & 600 & - \\
\hline $\mathrm{K}$ & $(\mathrm{mg} / \mathrm{kg})$ & $76(k)$ & - \\
\hline $\mathrm{Mg}$ & $(\mathrm{mg} / \mathrm{kg})$ & $560(0)$ & - \\
\hline $\mathrm{Na}$ & $(\mathrm{mg} / \mathrm{kg})$ & $69(0)(0)$ & ."' \\
\hline $\mathrm{Sr}$ & $(\mathrm{mg} / \mathrm{kg})$ & 110 & - \\
\hline Th (color) & $(\mathrm{mg} / \mathrm{kg})$ & - & 148() \\
\hline$U(I C P)$ & $(\mathrm{mg} / \mathrm{kg})$ & $37(K)$ & - \\
\hline
\end{tabular}

T'AL 


\section{C..35}

Stumple: W24-S

IPA

T'AL

Bota/gamma omiltors

Gross alpha

Gross beta

${ }^{14} \mathrm{C}$

${ }^{14} \mathrm{Ce}$

${ }^{n 10} \mathrm{Co}$

${ }^{1.44} \mathrm{C}$ 's

${ }^{1.17} \mathrm{Cs}$

${ }^{152} \mathrm{Eu}$

${ }^{15.4} \mathrm{Eu}$

${ }^{15 s} \mathrm{Eu}$

${ }^{9.5} \mathrm{Nb}$

${ }^{1 / 6} \mathrm{Ru}$

${ }^{90} \mathrm{Sr}$

${ }^{95} \mathrm{Zr}$

${ }^{21 .} \mathrm{U}$
${ }^{219} \mathrm{U}$
${ }^{219} \mathrm{Pu} /{ }^{240} \mathrm{Pu}$
${ }^{24.9} \mathrm{Cm}$
${ }^{241} \mathrm{Cm}$

\section{Alpha emilters}

$(\mathrm{Bc} / \mathrm{g})$

$(\mathrm{Bq} / \mathrm{g})$

$(\mathrm{Bc} / \mathrm{g})$

$(\mathrm{Bq} / \mathrm{g})$

$(\mathrm{Bq} / \mathrm{g})$

$(\mathrm{Bq} / \mathrm{g})$

$(\mathrm{Bq} / \mathrm{g})$

$(\mathrm{Bg} / \mathrm{g})$

$(\mathrm{Bq} / \mathrm{g})$

$(\mathrm{Bq} / \mathrm{g})$

$(\mathrm{Bq} / \mathrm{g})$

$(\mathrm{Bq} / \mathrm{g})$

$(\mathrm{Ba} / \mathrm{g})$

$(\mathrm{Bc} / \mathrm{g})$
$2.03 \mathrm{c}+(04$

$2.73 c+1) 6$

$8.43 \mathrm{c}+(12$

$-$

$3.510+(1) 4$

$1,94 c+(05$

$6.44 c+() 4$

$3.24 \mathrm{c}+(04$

.

.

$1.05 c+06$
$2.340+(14$

$2.620+16$

$<3,9 c+(1) 3$

$3.39 c+(1) 4$

$<6.2 \mathrm{c}+() 2$

$1.96 x+(1) 5$

$6.2(\mathrm{c}+(1) 4$

3.6()$+(1) 4$

$1.03 \mathrm{c}+(1) 4$

$<.5 .6 \mathrm{c}+(1) 2$

$<5.7 \mathrm{c}+(13$

$1.15 \mathrm{e}+(1) 6$

$<2.8 c+(0.3$

$\begin{array}{ccc}(\mathrm{Bq} / \mathrm{g}) & - & 5.15 \mathrm{c}+(1) \\ (\mathrm{Bq} / \mathrm{g}) & - & <3.7 \mathrm{c}+(13 \\ (\mathrm{Bq} / \mathrm{g}) & - & 1.54 \mathrm{c}+(0.3 \\ (\mathrm{Bq} / \mathrm{g}) & - & 3.74 \mathrm{c}+() 3 \\ (\mathrm{Bc} / \mathrm{g}) & - & <3.6 \mathrm{c}+(0) \\ (\mathrm{Bq} / \mathrm{g}) & - & 1.63 \mathrm{c}+() 4\end{array}$


Physical proporticas and miscollaneous data

$\begin{array}{llc}\text { TS } & (\mathrm{mg} / \mathrm{g}) & 531 \\ \text { Density } & (\mathrm{g} / \mathrm{mL}) & 1.32 \\ & & \\ \text { IC } & (\mathrm{mg} / \mathrm{kg}) & 3920 \\ \text { TC } & (\mathrm{mg} / \mathrm{kg}) & 6250 \\ \text { TOC } & (\mathrm{mg} / \mathrm{kg}) & 23.30\end{array}$

\section{RCRA motals}

\begin{tabular}{|c|c|c|}
\hline$\overline{\mathrm{Ag}}$ & $(\mathrm{mg} / \mathrm{kg})$ & $(<7.6)$ \\
\hline As & $(\mathrm{mg} / \mathrm{kg})$ & $<41$ \\
\hline $\mathrm{Ba}$ & $(\mathrm{mg} / \mathrm{kg})$ & 59 \\
\hline $\mathrm{Cd}$ & $(\mathrm{mg} / \mathrm{kg})$ & 11 \\
\hline $\mathrm{Cr}$ & $(\mathrm{mg} / \mathrm{kg})$ & 59 \\
\hline $\mathrm{Hg}$ & $(\mathrm{mg} / \mathrm{kg})$ & 37 \\
\hline $\mathrm{Ni}$ & $(\mathrm{mg} / \mathrm{kg})$ & .34 \\
\hline $\mathrm{Pb}$ & $(\mathrm{mg} / \mathrm{kg})$ & 220 \\
\hline $\mathrm{Sc}$ & $(\mathrm{mg} / \mathrm{kg})$ & $<51$ \\
\hline $\mathrm{Tl}$ & $(\mathrm{mg} / \mathrm{kg})$ & $<16$ \\
\hline
\end{tabular}

\section{Process motals}

$\begin{array}{lcc}\mathrm{Al} & (\mathrm{mg} / \mathrm{kg}) & 28(K) \\ \mathrm{B} & (\mathrm{mg} / \mathrm{kg}) & <1.5 \\ \mathrm{Ca} & (\mathrm{mg} / \mathrm{kg}) & 38(0)(0) \\ \mathrm{Cs} & (\mathrm{mg} / \mathrm{kg}) & (<1.3) \\ \mathrm{Fe} & (\mathrm{mg} / \mathrm{kg}) & 940) \\ \mathrm{K} & (\mathrm{mg} / \mathrm{kg}) & 920() \\ \mathrm{Mg} & (\mathrm{mg} / \mathrm{kg}) & 59(k) \\ \mathrm{Na} & (\mathrm{mg} / \mathrm{kg}) & 66(K) \\ \mathrm{Sr} & (\mathrm{mg} / \mathrm{kg}) & 150 \\ \mathrm{Th} \text { (color) } & (\mathrm{mg} / \mathrm{kg}) & - \\ \mathrm{U} \text { (ICP) } & (\mathrm{mg} / \mathrm{kg}) & 48(K)\end{array}$


TAL

\section{Bola/gamma conittors}

\begin{tabular}{|c|c|c|c|}
\hline Gross ulpha & $(\mathrm{Bq} / \mathrm{g})$ & $3.74 c+(14$ & $4.650+(1) 4$ \\
\hline Gross beta & $(\mathrm{Bc} / \mathrm{g})$ & $4.160+(k)$ & $4.1(1) c+(16)$ \\
\hline${ }^{11} \mathrm{C}$ & $(\mathrm{Bc} / \mathrm{g})$ & $1.710+(12$ & * \\
\hline${ }^{1+4} \mathrm{Cc}$ & $(\mathrm{Bq} / \mathrm{g})$ & - & $<4.2 c+(0) 3$ \\
\hline${ }^{(1)} \mathrm{Co}$ & $(\mathrm{Bq} / \mathrm{g})$ & $3.94 c+(04$ & $4 .(1) 3 \mathrm{c}+(04$ \\
\hline${ }^{1.4} \mathrm{Cs}$ & $(\mathrm{Bc} / \mathrm{g})$ & . & $7 .(17 c+(12$ \\
\hline${ }^{1.17} \mathrm{Cs}$ & $(\mathrm{Bq} / \mathrm{g})$ & $2.14 c+05$ & $2.21 \mathrm{c}+(1) 5$ \\
\hline${ }^{152} \mathrm{Eu}$ & $(\mathrm{Bc} / \mathrm{g})$ & $8.54 c+04$ & $8.14 c+(14$ \\
\hline${ }^{154} \mathrm{Eu}$ & $(\mathrm{Bq} / \mathrm{g})$ & $4.96 c+04$ & $5 .(16 c+0) 4$ \\
\hline${ }^{159} \mathrm{Eu}$ & $(\mathrm{Bq} / \mathrm{g})$ & $1.59 \mathrm{c}+(14$ & $1.63 c+(14$ \\
\hline${ }^{95} \mathrm{Nb}$ & $(B \mathrm{~B} / \mathrm{g})$ & - & $<5.9 c+(1) 2$ \\
\hline${ }^{10 x} \mathrm{Ru}$ & $(\mathrm{Bg} / \mathrm{g})$ & 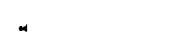 & $<5.9 c+(1) 3$ \\
\hline${ }^{91} \mathrm{Sr}$ & $(\mathrm{Bq} / \mathrm{g})$ & $1.65 c+06$ & $1.730+(1) 6$ \\
\hline${ }^{95} \mathrm{Zr}$ & $(\mathrm{Bc} / \mathrm{g})$ & . & $<4.6 x+(1) 3$ \\
\hline
\end{tabular}

Alpha cmittors

${ }^{21.1} \mathrm{U}$
${ }^{21 .} \mathrm{U}$
${ }^{210} \mathrm{Pu} /{ }^{214} \mathrm{Pu} /{ }^{211} \mathrm{Pum}$
${ }^{24.1} \mathrm{Cm}$
${ }^{2 \cdot 14} \mathrm{Cm}$

$\begin{array}{cc} & 8.37 \mathrm{c}+(12 \\ . & <4.2 \mathrm{c}+(1) 3 \\ - & 2.93 \mathrm{c}+(0.3 \\ . & 7.35 \mathrm{c}+(1.3 \\ - & <3.9 \mathrm{c}+(0.3 \\ . & 3.32 \mathrm{c}+(14\end{array}$


Physical proportics and miscollancous datil

TSS

Donsily

IC

TC

TOC

$(\mathrm{mg} / \mathrm{g})$

$(\mathrm{g} / \mathrm{mL})$

1.54

12(KK)

$(\mathrm{mg} / \mathrm{kg})$

(mg/kg')

(mg/kg)

$182(x)$

6220

RCRA motuls

Ag

As

$B \backsim$

$\mathrm{Cd}$

$\mathrm{Cr}$

$\mathrm{Hg}$

$\mathrm{Ni}$

$\mathrm{Pb}$

Sc

'Tl $(\mathrm{mg} / \mathrm{kg})$

( $\mathrm{mg} / \mathrm{kg})$

(mg/kg)

( $\mathrm{mg} / \mathrm{kg})$

(mg/kg)

(mg/kg)

( $m g / k g)$

(mg/kg)

$(\mathrm{mg} / \mathrm{kg})$

(mg/kg)
(3))

(b)

87

42

170)

64

92

470)

$<.55$

$<17$

Processs motals

Al

B

$\mathrm{Ca}$

$\mathrm{Fc}$

$\mathrm{K}$

$\mathrm{Mg}$

$\mathrm{Na}$

$\mathrm{Sr}$

Th (color)

U (fluor) $(\mathrm{mg} / \mathrm{kg})$

$(\mathrm{mg} / \mathrm{kg})$

( $\mathrm{mg} / \mathrm{kg}$ )

( $\mathrm{mg} / \mathrm{kg}$ )

$(\mathrm{mg} / \mathrm{kg})$

( $m g / k g)$

(mg/kg)

$(\mathrm{mg} / \mathrm{kg})$

(mg/kg)

(mg/kg)
75()

$<7.3$

$3(0)(1)$

$23(k)$

15()K)

11(KK)

$510(x)$

120)

$241(k)$

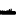


Bota/gamma omiltors

\begin{tabular}{|c|c|c|c|}
\hline Gross alpha & $(\mathrm{Bq} / \mathrm{g})$ & $8.14 c+(144$ & $9.13 c+(14$ \\
\hline Gross betu & $(\mathrm{Bc} / \mathrm{g})$ & $5.6(5) c+06$ & 5.7() $\mathrm{e}+(1) 6$ \\
\hline${ }^{11} \mathrm{C}$ & $(B \mathrm{~g} / \mathrm{g})$ & $2.13 c+02$ & - \\
\hline${ }^{14} \mathrm{Ce}$ & $(\mathrm{Bq} / \mathrm{g})$ & - & $<1.20+(14$ \\
\hline${ }^{60} \mathrm{Co}$ & $(\mathrm{Bg} / \mathrm{g})$ & $1,03 \mathrm{c}+0.5$ & $1.03 \mathrm{c}+05$ \\
\hline${ }^{1.94} \mathrm{Cs}$ & $(\mathrm{Bc} / \mathrm{g})$ & $2.38 \mathrm{c}+(1) 3$ & $2.97 c+13$ \\
\hline${ }^{1.31} \mathrm{Cs}$ & $(B c / g)$ & $7.03 c+05$ & $6.84 c+05$ \\
\hline${ }^{1 \leqslant 2} E \mathrm{Eu}$ & $(\mathrm{Bq} / \mathrm{g})$ & $5.53 c+0.5$ & $4.92 c+(05$ \\
\hline${ }^{1: 4} \mathrm{Eu}$ & $(\mathrm{Bq} / \mathrm{g})$ & $3 .(1) \mathrm{c}+0.5$ & $3.190+(05$ \\
\hline${ }^{M} \mathrm{Eu}$ & $(\mathrm{Bq} / \mathrm{g})$ & $7.32 \mathrm{e}+(04$ & $7.51 \mathrm{c}+04$ \\
\hline${ }^{4 !} \mathrm{Nb}$ & $(\mathrm{Bc} / \mathrm{g})$ & - & $<2,6 \mathrm{e}+(0) 3$ \\
\hline${ }^{1 / x_{1}} R u$ & $(\mathrm{~Bq} / \mathrm{g})$ & . & $<2.5 c+() 4$ \\
\hline${ }^{*} \mathrm{Sr}$ & $(\mathrm{Bq} / \mathrm{g})$ & $2 .(03 c+1) 6$ & $1.84 \mathrm{c}+(1)$ \\
\hline${ }^{45} \mathrm{Zr}$ & $(\mathrm{Bc} / \mathrm{g})$ & - & $<1.3 \mathrm{c}+(05$ \\
\hline
\end{tabular}

Alpha cmilters

\begin{tabular}{|c|c|c|c|}
\hline${ }^{211} \mathrm{U}$ & $(\mathrm{Bg} / \mathrm{g})$ & - & $6.66 c+(1.3$ \\
\hline${ }^{21 !} \mathrm{U}$ & $(\mathrm{Bq} / \mathrm{g})$ & - & $<1.20+04$ \\
\hline${ }^{219} \mathrm{Pu} /{ }^{211} \mathrm{Pu}$ & $(\mathrm{Bc} / \mathrm{g})$ & - & $5.11 \mathrm{c}+(0.3$ \\
\hline${ }^{211} \mathrm{Pu} /{ }^{411} \mathrm{Am}$ & $(\mathrm{Bq} / \mathrm{g})$ & " & $1.48 \mathrm{c}+(14$ \\
\hline${ }^{24 \cdot} \mathrm{Cm}$ & $(\mathrm{Bc} / \mathrm{g})$ & - & $<1.3 \mathrm{c}+(1) 4$ \\
\hline${ }^{2+4} \mathrm{Cm}$ & $(\mathrm{Bq} / \mathrm{g})$ & . & $6.14 c+(1) 4$ \\
\hline
\end{tabular}


Physical proportices and miscollancous data

$\begin{array}{llr}\text { TS } & (\mathrm{mg} / \mathrm{g}) & 386 \\ \text { Densily } & (\mathrm{g} / \mathrm{mL}) & 1.26 \\ \text { IC } & (\mathrm{mg} / \mathrm{kg}) & 5250 \\ \text { TC } & (\mathrm{mg} / \mathrm{kg}) & 7690 \\ \text { TOC } & (\mathrm{mg} / \mathrm{kg}) & 2440\end{array}$

\section{RCRA motals}

\begin{tabular}{|c|c|c|}
\hline $\mathrm{Ag}$ & $(\mathrm{mg} / \mathrm{kg})$ & $(<7.2)$ \\
\hline As & $(\mathrm{mg} / \mathrm{kg})$ & $<39$ \\
\hline $\mathrm{Ba}$ & $(\mathrm{mg} / \mathrm{kg})$ & 49 \\
\hline $\mathrm{Cd}$ & $(\mathrm{mg} / \mathrm{kg})$ & 13 \\
\hline $\mathrm{Cr}$ & $(\mathrm{mg} / \mathrm{kg})$ & 65 \\
\hline $\mathrm{Hg}$ & $(\mathrm{mg} / \mathrm{kg})$ & 11 \\
\hline $\mathrm{Ni}$ & $(\mathrm{mg} / \mathrm{kg})$ & 27 \\
\hline $\mathrm{Pb}$ & $(\mathrm{mg} / \mathrm{kg})$ & 120 \\
\hline Sc & $(\mathrm{mg} / \mathrm{kg})$ & $<49$ \\
\hline 'T'] & $(\mathrm{mg} / \mathrm{kg})$ & 20 \\
\hline
\end{tabular}

\section{Process motals}

Al

B

$\mathrm{Ca}$

$\mathrm{Fe}$

$\mathrm{K}$

$\mathrm{Mg}$

$\mathrm{Na}$

$\mathrm{Sr}$

Th (color)

U (fluor) $(\mathrm{mg} / \mathrm{kg})$

(mg/kg)

$(\mathrm{mg} / \mathrm{kg})$

$(\mathrm{mg} / \mathrm{kg})$

( $\mathrm{mg} / \mathrm{kg}$ )

$(\mathrm{mg} / \mathrm{kg})$

$(\mathrm{mg} / \mathrm{kg})$

(mg/kg)

(mg/kg)

(mg/kg)

$43(10)$
$<6.4$
$380(0)$
$14(0)$
$61(0)$
$48(0)$
$710(0)$
120
2710

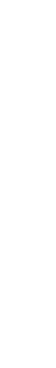




\section{Beta/gamma emitters}

Gross alpha
Gross beta
${ }^{14} \mathrm{C}$
${ }^{144} \mathrm{Ce}$
${ }^{60} \mathrm{Co}$
${ }^{134} \mathrm{Cs}$
${ }^{137} \mathrm{Cs}$
${ }^{152} \mathrm{Eu}$
${ }^{154} \mathrm{Eu}$
${ }^{155} \mathrm{Eu}$
${ }^{95} \mathrm{Nb}$
${ }^{106} \mathrm{Ru}$
${ }^{95} \mathrm{Sr}$
${ }^{95} \mathrm{Zr}$

$(\mathrm{Bq} / \mathrm{g})$

$(\mathrm{Bq} / \mathrm{g})$

$(\mathrm{Bq} / \mathrm{g})$

$(\mathrm{Bq} / \mathrm{g})$

$(\mathrm{Bq} / \mathrm{g})$

$(\mathrm{Bq} / \mathrm{g})$

$(\mathrm{Bq} / \mathrm{g})$

$(\mathrm{Bq} / \mathrm{g})$

(Bq/g)

$(\mathrm{Bq} / \mathrm{g})$

(Bq/g)

$(\mathrm{Bq} / \mathrm{g})$

(Bq/g)

(Bq/g)
$1.85 \mathrm{e}+04$

$1.50 \mathrm{e}+06$

$1.89 \mathrm{e}+02$

$1.55 \mathrm{e}+04$

-

$4.26 \mathrm{e}+05$

$2.16 \mathrm{e}+04$

$1.28 \mathrm{e}+04$

$2.72 \mathrm{e}+03$

-

-

$4.55 \mathrm{e}+05$

-

$$
\begin{gathered}
2.25 \mathrm{e}+04 \\
1.44 \mathrm{e}+06 \\
- \\
<5.6 \mathrm{e}+03 \\
1.61 \mathrm{e}+04 \\
<1.2 \mathrm{e}+03 \\
3.75 \mathrm{e}+05 \\
1.99 \mathrm{e}+04 \\
1.26 \mathrm{e}+04 \\
<3.4 \mathrm{e}+03 \\
<7.3 \mathrm{e}+02 \\
<1.1 \mathrm{e}+04 \\
4.21 \mathrm{e}+05 \\
<1.7 \mathrm{e}+03
\end{gathered}
$$

\section{Alpha emitters}

${ }^{233} \mathrm{U}$
${ }^{239} \mathrm{U}$
${ }^{238} \mathrm{Pu} /{ }^{40} \mathrm{Pu} /{ }^{41} \mathrm{Am}$
${ }^{243} \mathrm{Cm}$
${ }^{244} \mathrm{Cm}$

(Bq/g)

$(\mathrm{Bq} / \mathrm{g})$

$(\mathrm{Bq} / \mathrm{g})$

$(\mathrm{Bq} / \mathrm{g})$

$(\mathrm{Bq} / \mathrm{g})$

(Bq/g)

$\begin{array}{cc}- & 5.18 \mathrm{e}+02 \\ - & <5.8 \mathrm{e}+03 \\ - & 1.04 \mathrm{e}+03 \\ - & 4.41 \mathrm{e}+03 \\ - & <6.5 \mathrm{e}+03 \\ - & 1.60 \mathrm{e}+04\end{array}$


Sample: W27-H1-H ${ }^{\mathrm{a}}$ IPA

TAL

Physical properties and miscellaneous data

TS

Density

IC

TC

TOC

RCRA metals

$\mathrm{Ag}$

As

$\mathrm{Ba}$

$\mathrm{Cd}$

$\mathrm{Cr}$

$\mathrm{Hg}$

$\mathrm{Ni}$

$\mathrm{Pb}$

$\mathrm{Se}$

$\mathrm{Tl}$ $(\mathrm{mg} / \mathrm{g})$

$(\mathrm{g} / \mathrm{mL})$

( $\mathrm{mg} / \mathrm{kg}$ )

$(\mathrm{mg} / \mathrm{kg})$

$(\mathrm{mg} / \mathrm{kg})$
471

\subsection{3}

12700

16500

3830

$\begin{array}{llr}\mathrm{Al} & (\mathrm{mg} / \mathrm{kg}) & 6800 \\ \mathrm{~B} & (\mathrm{mg} / \mathrm{kg}) & <11 \\ \mathrm{Ca} & (\mathrm{mg} / \mathrm{kg}) & 54000 \\ \mathrm{Fe} & (\mathrm{mg} / \mathrm{kg}) & 2500 \\ \mathrm{~K} & (\mathrm{mg} / \mathrm{kg}) & 6700 \\ \mathrm{Mg} & (\mathrm{mg} / \mathrm{kg}) & 5900 \\ \mathrm{Na} & (\mathrm{mg} / \mathrm{kg}) & 66000 \\ \mathrm{Sr} & (\mathrm{mg} / \mathrm{kg}) & 150 \\ \mathrm{Th} \text { (color) } & (\mathrm{mg} / \mathrm{kg}) & - \\ \mathrm{U} \text { (lluor) } & (\mathrm{mg} / \mathrm{kg}) & 1960\end{array}$

$(<13)$

$<69$

72

17

90

18

40

200

$<86$

$<27$

\section{Process metals}

B

(mg/kg)

( $\mathrm{mg} / \mathrm{kg})$

(mg/kg)

(mg/kg)

$(\mathrm{mg} / \mathrm{kg})$

- 


\begin{tabular}{|c|c|c|c|}
\hline Sample: W27-H1-H ${ }^{a}$ & & IPA & TAL \\
\hline \multicolumn{4}{|l|}{ Beta/gamma emitters } \\
\hline Gross alpha & $(\mathrm{Bq} / \mathrm{g})$ & $2.59 e+04$ & $3.10 \mathrm{e}+04$ \\
\hline Gross beta & $(\mathrm{Bq} / \mathrm{g})$ & $1.88 \mathrm{e}+06$ & $2.02 e+06$ \\
\hline${ }^{14} \mathrm{C}$ & $(\mathrm{Bq} / \mathrm{g})$ & $4.86 \mathrm{e}+02$ & - \\
\hline${ }^{144} \mathrm{Ce}$ & $(\mathrm{Bq} / \mathrm{g})$ & - & $<7.7 e+03$ \\
\hline${ }^{60} \mathrm{Co}$ & $(\mathrm{Bq} / \mathrm{g})$ & $1.83 e+04$ & $2.50 \mathrm{e}+04$ \\
\hline${ }^{134} \mathrm{Cs}$ & $(\mathrm{Bq} / \mathrm{g})$ & $7.36 \mathrm{e}+02$ & $<1.8 \mathrm{e}+03$ \\
\hline${ }^{137} \mathrm{Cs}$ & $(\mathrm{Bq} / \mathrm{g})$ & $5.40 \mathrm{e}+05$ & $5.71 \mathrm{e}+05$ \\
\hline${ }^{152} \mathrm{Eu}$ & $(\mathrm{Bq} / \mathrm{g})$ & $2.86 \mathrm{e}+04$ & $2.42 \mathrm{e}+04$ \\
\hline${ }^{154} \mathrm{Eu}$ & $(\mathrm{Bq} / \mathrm{g})$ & $1.42 \mathrm{e}+04$ & $1.51 \mathrm{e}+04$ \\
\hline${ }^{155} \mathrm{Eu}$ & $(\mathrm{Bq} / \mathrm{g})$ & $4.19 e+03$ & $3.26 \mathrm{e}+03$ \\
\hline${ }^{95} \mathrm{Nb}$ & $(\mathrm{Bq} / \mathrm{g})$ & - & $<1.4 \mathrm{e}+03$ \\
\hline${ }^{106} \mathrm{Ru}$ & $(\mathrm{Bq} / \mathrm{g})$ & - & $<1.6 \mathrm{e}+04$ \\
\hline${ }^{x} \mathrm{Sr}$ & $(\mathrm{Bq} / \mathrm{g})$ & $5.51 \mathrm{e}+05$ & $6.15 \mathrm{e}+05$ \\
\hline${ }^{9} \mathrm{Zr}$ & $(\mathrm{Bq} / \mathrm{g})$ & - & $<2.6 \mathrm{e}+03$ \\
\hline \multicolumn{4}{|l|}{ Alpha emitters } \\
\hline${ }^{233} \mathrm{U}$ & $(\mathrm{Bq} / \mathrm{g})$ & - & $6.20 \mathrm{e}+02$ \\
\hline${ }^{215} \mathrm{U}$ & $(\mathrm{Bq} / \mathrm{g})$ & - & $<8.3 \mathrm{e}+03$ \\
\hline${ }^{239} \mathrm{Pu} /{ }^{240} \mathrm{Pu}$ & $(\mathrm{Bg} / \mathrm{g})$ & - & $1.86 \mathrm{e}+03$ \\
\hline${ }^{238} \mathrm{Pu} /{ }^{241} \mathrm{Am}$ & $(\mathrm{Bq} / \mathrm{g})$ & - & $6.73 e+03$ \\
\hline${ }^{243} \mathrm{Cm}$ & $(\mathrm{Bq} / \mathrm{g})$ & - & $<1.0 \mathrm{e}+04$ \\
\hline${ }^{244} \mathrm{Cm}$ & $(\mathrm{Bq} / \mathrm{g})$ & - & $2.15 \mathrm{c}+04$ \\
\hline
\end{tabular}

a Sample W27-H1-H contained no free liquid and was not sonicated. 
Physical propertics and miscellaneous data

$$
\text { 'TS }
$$

Density

IC

TC

TOC

$(\mathrm{mg} / \mathrm{g})$

$(\mathrm{g} / \mathrm{mL})$

1.49

$(\mathrm{mg} / \mathrm{kg})$

$(\mathrm{mg} / \mathrm{kg})$

$(\mathrm{mg} / \mathrm{kg})$

3620

6120

2500

\section{RCRA metals}

$\begin{array}{lll}\mathrm{Ag} & (\mathrm{mg} / \mathrm{kg}) & (17) \\ \mathrm{As} & (\mathrm{mg} / \mathrm{kg}) & 27 \\ \mathrm{Ba} & (\mathrm{mg} / \mathrm{kg}) & 39 \\ \mathrm{Cd} & (\mathrm{mg} / \mathrm{kg}) & 26 \\ \mathrm{Cr} & (\mathrm{mg} / \mathrm{kg}) & 55 \\ \mathrm{Hg} & (\mathrm{mg} / \mathrm{kg}) & 12 \\ \mathrm{Ni} & (\mathrm{mg} / \mathrm{kg}) & 62 \\ \mathrm{~Pb} & (\mathrm{mg} / \mathrm{kg}) & 190 \\ \mathrm{Se} & (\mathrm{mg} / \mathrm{kg}) & <29 \\ \mathrm{Tl} & (\mathrm{mg} / \mathrm{kg}) & <9\end{array}$

\section{Process metals}

$\begin{array}{lccc}\mathrm{Al} & (\mathrm{mg} / \mathrm{kg}) & 830 \\ \mathrm{~B} & (\mathrm{mg} / \mathrm{kg}) & 4.9 \\ \mathrm{Ca} & (\mathrm{mg} / \mathrm{kg}) & 57000 \\ \mathrm{Cs} & (\mathrm{mg} / \mathrm{kg}) & (<0.8) \\ \mathrm{Fc} & (\mathrm{mg} / \mathrm{kg}) & 630 \\ \mathrm{~K} & (\mathrm{mg} / \mathrm{kg}) & 110(K K) \\ \mathrm{Mg} & (\mathrm{mg} / \mathrm{kg}) & 150(0) \\ \mathrm{Na} & (\mathrm{mg} / \mathrm{kg}) & 66000 \\ \mathrm{Sr} & (\mathrm{mg} / \mathrm{kg}) & 130 \\ \mathrm{Th} \text { (color) } & (\mathrm{mg} / \mathrm{kg}) & - \\ \mathrm{U} \text { (ICP) } & (\mathrm{mg} / \mathrm{kg}) & 17000\end{array}$$$
<9
$$ 


\section{Sample: W28-S \\ Beta/gamma emitters}

IPA

TAL

Gross alpha
Gross beta
${ }^{14} \mathrm{C}$
${ }^{144} \mathrm{Ce}$
${ }^{60} \mathrm{Co}$
${ }^{134} \mathrm{Cs}$
${ }^{137} \mathrm{Cs}$
${ }^{152} \mathrm{Eu}$
${ }^{154} \mathrm{Eu}$
${ }^{155} \mathrm{Eu}$
${ }^{95} \mathrm{Nb}$
${ }^{106} \mathrm{Ru}$
${ }^{90} \mathrm{Sr}$
${ }^{95} \mathrm{Zr}$

$(\mathrm{Bq} / \mathrm{g})$

$(\mathrm{Bq} / \mathrm{g})$

$(\mathrm{Bq} / \mathrm{g})$

$(\mathrm{Bq} / \mathrm{g})$

$(\mathrm{Bq} / \mathrm{g})$

$(\mathrm{Bq} / \mathrm{g})$

$(\mathrm{Bq} / \mathrm{g})$

$(\mathrm{Bq} / \mathrm{g})$

$(\mathrm{Bq} / \mathrm{g})$

$(\mathrm{Bq} / \mathrm{g})$

$(\mathrm{Bq} / \mathrm{g})$

$(\mathrm{Bq} / \mathrm{g})$

$(\mathrm{Bq} / \mathrm{g})$

$(\mathrm{Bq} / \mathrm{g}$ )
$4.66 \mathrm{e}+04$

$2.39 \mathrm{e}+06$

$7.60 \mathrm{e}+01$

$-$

$7.48 \mathrm{e}+04$

$3.38 \mathrm{e}+03$

$1.84 \mathrm{e}+05$

$7.08 \mathrm{e}+05$

$2.84 \mathrm{e}+05$

$8.87 \mathrm{e}+04$

-

$1.92 \mathrm{e}+04$

$5.57 \mathrm{e}+05$

-

$\begin{array}{cc}- & 1.46 \mathrm{c}+03 \\ - & 3.56 \mathrm{c}+03 \\ - & <1.7 \mathrm{e}+04 \\ - & 1.51 \mathrm{c}+03 \\ - & 5.28 \mathrm{c}+03 \\ - & <1.4 \mathrm{c}+04 \\ - & 3.83 \mathrm{c}+04\end{array}$

$$
\begin{gathered}
5.39 \mathrm{e}+04 \\
2.40 \mathrm{e}+06 \\
- \\
<1.7 \mathrm{e}+04 \\
7.91 \mathrm{e}+04 \\
<4.6 \mathrm{e}+03 \\
1.94 \mathrm{e}+05 \\
7.18 \mathrm{e}+05 \\
3.20 \mathrm{e}+05 \\
9.70 \mathrm{e}+04 \\
<2.9 \mathrm{e}+03 \\
<2.8 \mathrm{e}+04 \\
6.06 \mathrm{e}+05 \\
<2.4 \mathrm{e}+04
\end{gathered}
$$

\section{Alpha cmitters}

${ }^{2213} \mathrm{U}$
${ }^{23.5} \mathrm{U}$
${ }^{219} \mathrm{Pu} /{ }^{240} \mathrm{Pu}$
${ }^{238} \mathrm{Pu} /{ }^{241} \mathrm{Am}$
${ }^{243} \mathrm{Cm}$
${ }^{244} \mathrm{Cm}$

(Bq/g)

(Bq/g)

(Bq/g)

$(\mathrm{Bq} / \mathrm{g})$

$(\mathrm{Bq} / \mathrm{g})$

$(\mathrm{Bq} / \mathrm{g})$

$(\mathrm{Bq} / \mathrm{g})$ 
Physical propertics and miscellancous data

$\begin{array}{llr}\text { TS } & (\mathrm{mg} / \mathrm{g}) & 369 \\ \text { Density } & (\mathrm{g} / \mathrm{mL}) & 1.26 \\ & & \\ \text { IC } & (\mathrm{mg} / \mathrm{kg}) & 1410 \\ \text { TC } & (\mathrm{mg} / \mathrm{kg}) & 1820 \\ \text { TOC } & (\mathrm{mg} / \mathrm{kg}) & 410\end{array}$

\section{RCRA metals}

$\begin{array}{llc}\mathrm{Ag} & (\mathrm{mg} / \mathrm{kg}) & (6.1) \\ \mathrm{As} & (\mathrm{mg} / \mathrm{kg}) & <33 \\ \mathrm{Ba} & (\mathrm{mg} / \mathrm{kg}) & 17 \\ \mathrm{Cd} & (\mathrm{mg} / \mathrm{kg}) & 1.7 \\ \mathrm{Cr} & (\mathrm{mg} / \mathrm{kg}) & 27 \\ \mathrm{Hg} & (\mathrm{mg} / \mathrm{kg}) & 14 \\ \mathrm{Ni} & (\mathrm{mg} / \mathrm{kg}) & 17 \\ \mathrm{~Pb} & (\mathrm{mg} / \mathrm{kg}) & 170 \\ \mathrm{Se} & (\mathrm{mg} / \mathrm{kg}) & <41 \\ \mathrm{Tl} & (\mathrm{mg} / \mathrm{kg}) & <13\end{array}$

\section{Process molals}

$\begin{array}{llcc}\mathrm{Al} & & (\mathrm{mg} / \mathrm{kg}) & 1400 \\ \mathrm{~B} & & (\mathrm{mg} / \mathrm{kg}) & <1.2 \\ \mathrm{Ca} & & (\mathrm{mg} / \mathrm{kg}) & 5600 \\ \mathrm{Cs} & & (\mathrm{mg} / \mathrm{kg}) & (<1.1) \\ \mathrm{Fe} & & (\mathrm{mg} / \mathrm{kg}) & 420 \\ \mathrm{~K} & (\mathrm{mg} / \mathrm{kg}) & 7900 \\ \mathrm{Mg} & (\mathrm{mg} / \mathrm{kg}) & 870 \\ \mathrm{Na} & (\mathrm{mg} / \mathrm{kg}) & 69000 \\ \mathrm{Sr} & (\mathrm{mg} / \mathrm{kg}) & 30 \\ \mathrm{Th} \text { (color }) & (\mathrm{mg} / \mathrm{kg}) & - \\ \mathrm{U} \text { (ICP) } & (\mathrm{mg} / \mathrm{kg}) & 300()\end{array}$


TAL

\section{Beta/gamma emitters}

Gross alpha

Gross bela

${ }^{14} \mathrm{C}$

${ }^{144} \mathrm{Ce}$

${ }^{(n)} \mathrm{Co}$

${ }^{13.4} \mathrm{Cs}$

${ }^{1.7 .7 \mathrm{Cs}}$

${ }^{152} \mathrm{Eu}$

${ }^{15.4} \mathrm{Eu}$

${ }^{155} \mathrm{Eu}$

${ }^{95} \mathrm{Nb}$

${ }^{106} \mathrm{Ru}$

${ }^{\mathrm{N}} \mathrm{Sr}$

${ }^{95} \mathrm{Zr}$

Alpha emitters

${ }^{233} \mathrm{U}$
${ }^{235} \mathrm{U}$
${ }^{239} \mathrm{Pu} /{ }^{240} \mathrm{Pu}$
${ }^{238} \mathrm{Pu} /{ }^{241} \mathrm{Am}$
${ }^{24.3} \mathrm{Cm}$
${ }^{244} \mathrm{Cm}$

$(\mathrm{Bq} / \mathrm{g})$

$(\mathrm{Bq} / \mathrm{g})$

$(\mathrm{Bq} / \mathrm{g})$

$(\mathrm{Bq} / \mathrm{g})$

$(\mathrm{Bq} / \mathrm{g})$

$(\mathrm{Bq} / \mathrm{g})$
$2.12 \mathrm{e}+(14$

$3.35 \mathrm{c}+(1)$

$3.14 \mathrm{c}+(12$

$-$

$7.26 x+0.3$

$3.52 \mathrm{e}+(0) 3$

$2.35 \mathrm{c}+0.5$

$8.73 \mathrm{c}+(0) 3$

$5.66 \mathrm{c}+0.3$

-

$-$

-

$1.42 \mathrm{c}+06$

$(\mathrm{Bq} / \mathrm{g})$

$(\mathrm{Bq} / \mathrm{g})$
$2.31 \mathrm{c}+(14$

$3.18 \mathrm{c}+06$

-

$<9.4 \mathrm{c}+(03$

$8.1(c+0) 3$

$3.64 \mathrm{c}+03$

$2.35 \mathrm{c}+0.5$

$<1.7 \mathrm{e}+(04$

$5.86 c+0.3$

$<5.9 \mathrm{c}+(0.3$

$<9.2 \mathrm{e}+(12$

$<1.4 \mathrm{c}+04$

$1.43 \mathrm{c}+(06$

$<4.7 \mathrm{e}+(03$
$5.08 \mathrm{c}+02$

$<9.7 \mathrm{e}+0.3$

$8.78 \mathrm{c}+02$

$2.43 \mathrm{c}+(03$

$<8.4 \mathrm{e}+(03$

$1.71 \mathrm{e}+04$ 
Physical propertics and miscellancous data

TS

Densily

IC

TC

TOC

$(\mathrm{mg} / \mathrm{g})$

$(\mathrm{g} / \mathrm{mL})$

( $\mathrm{mg} / \mathrm{kg}$ )

$(\mathrm{mg} / \mathrm{kg}$ )

( $\mathrm{mg} / \mathrm{kg}$ )

$219(x)$

$3(04()$

853()

RCRA motals

$\mathrm{Ag}$

As

$\mathrm{Ba}$

$\mathrm{Cd}$

$\mathrm{Cr}$

$\mathrm{Hg}$

$\mathrm{Ni}$

$\mathrm{Pb}$

$\mathrm{Sc}$

TI $(\mathrm{mg} / \mathrm{kg})$

( $\mathrm{mg} / \mathrm{kg})$

$(\mathrm{mg} / \mathrm{kg})$

$(\mathrm{mg} / \mathrm{kg})$

$(\mathrm{mg} / \mathrm{kg})$

$(\mathrm{mg} / \mathrm{kg})$

(mg/kg)

$(\mathrm{mg} / \mathrm{kg})$

$(\mathrm{mg} / \mathrm{kg})$

(mg/kg)
(5.4)

$<29$

18()

1.5

75

39

52

$360)$

$<37$

$<11$

Process motals

$\begin{array}{lcc}\mathrm{Al} & (\mathrm{mg} / \mathrm{kg}) & 160(0) \\ \mathrm{B} & (\mathrm{mg} / \mathrm{kg}) & 22 \\ \mathrm{Ca} & (\mathrm{mg} / \mathrm{kg}) & 620(0) \\ \mathrm{Cs} & (\mathrm{mg} / \mathrm{kg}) & (2.4) \\ \mathrm{Fc} & (\mathrm{mg} / \mathrm{kg}) & 77(0) \\ \mathrm{K} & (\mathrm{mg} / \mathrm{kg}) & 6700 \\ \mathrm{Mg} & (\mathrm{mg} / \mathrm{kg}) & 310() \\ \mathrm{Na} & (\mathrm{mg} / \mathrm{kg}) & 4800() \\ \mathrm{Sr} & (\mathrm{mg} / \mathrm{kg}) & 170 \\ \mathrm{Th} \text { (color) } & (\mathrm{mg} / \mathrm{kg}) & - \\ \mathrm{U} \text { (ICP) } & (\mathrm{mg} / \mathrm{kg}) & 920()\end{array}$

$118(0)$ 
IPA

T'AL

Beta/gamma emitters

$\begin{array}{ll}\text { Gross alpha } & (\mathrm{Bq} / \mathrm{g}) \\ \text { Gross beta } & (\mathrm{Bq} / \mathrm{g}) \\ { }^{14} \mathrm{C} & (\mathrm{Bq} / \mathrm{g}) \\ { }^{144} \mathrm{Ce} & (\mathrm{Bq} / \mathrm{g}) \\ { }^{60} \mathrm{Co} & (\mathrm{Bq} / \mathrm{g}) \\ { }^{134} \mathrm{Cs} & (\mathrm{Bq} / \mathrm{g}) \\ { }^{13.7} \mathrm{Cs} & (\mathrm{Bq} / \mathrm{g}) \\ { }^{152} \mathrm{Eu} & (\mathrm{Bq} / \mathrm{g}) \\ { }^{154} \mathrm{Eu} & (\mathrm{Bq} / \mathrm{g}) \\ { }^{155} \mathrm{Eu} & (\mathrm{Bq} / \mathrm{g}) \\ { }^{95} \mathrm{Nb} & (\mathrm{Bq} / \mathrm{g}) \\ { }^{106} \mathrm{Ru} & (\mathrm{Bq} / \mathrm{g}) \\ { }^{90} \mathrm{Sr} & (\mathrm{Bq} / \mathrm{g}) \\ { }^{95} \mathrm{Zr} & (\mathrm{Bq} / \mathrm{g})\end{array}$

Alpha emitters

${ }^{2313} \mathrm{U}$
${ }^{235} \mathrm{U}$
${ }^{219} \mathrm{Pu} /{ }^{210} \mathrm{Pu} /{ }^{241} \mathrm{Am}$
${ }^{219} \mathrm{Cm}$
${ }^{244} \mathrm{Cm}$

$(\mathrm{Bq} / \mathrm{g})$

$(\mathrm{Bq} / \mathrm{g})$

$(\mathrm{Bq} / \mathrm{g})$

$(\mathrm{Bq} / \mathrm{g})$

$(\mathrm{Bc} / \mathrm{g})$

$(\mathrm{Bq} / \mathrm{g})$

$\begin{array}{lc}8.52 \mathrm{c}+04 & 8.95 \mathrm{c}+(04 \\ 1.17 \mathrm{c}+07 & 1.1(0 \mathrm{c}+(07 \\ 1.05 \mathrm{c}+(03 & - \\ - & <1.4 \mathrm{c}+(04 \\ 2.83 \mathrm{c}+(04 & 3.01 \mathrm{c}+(04 \\ 3.25 \mathrm{c}+03 & 2.07 \mathrm{c}+(03 \\ 5.64 \mathrm{c}+05 & 5.52 \mathrm{c}+05 \\ 2.16 \mathrm{c}+04 & 2.72 \mathrm{c}+(04 \\ 1.62 \mathrm{e}+04 & 2.07 \mathrm{c}+(04 \\ - & <8.7 \mathrm{c}+03 \\ - & <1.2 \mathrm{e}+(13 \\ - & <1.7 \mathrm{c}+(04 \\ 5.17 \mathrm{c}+06 & 5.29 \mathrm{c}+(06 \\ - & <6.6 \mathrm{c}+(1)\end{array}$

$2.05 \mathrm{c}+(0.3$

$<1.4 \mathrm{c}+(04$

$3.22 \mathrm{c}+(0.3$

$1.12 \mathrm{e}+() 4$

$<1.3 \mathrm{c}+() 4$

$6.89 \mathrm{c}+(04$

"Density was not measured on W31-H because the sample had dried to hard lumps and meaningful data could not be obtained. 
APPENDIX D

ORGANIC CHEMICAL CHARACTERIZATION 


\section{APPENDIX D CON'TENTS}

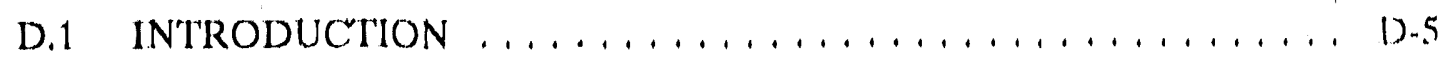

D.2 METHODS AND MA'TERIALS $\ldots \ldots \ldots \ldots \ldots \ldots \ldots \ldots \ldots$

D.2.1 Volatile Organic Components ol Aquoous Sumples . . . . . . . . D-6 D.2.2 Direct Aqueous Injoction Gas Chromatography for Major

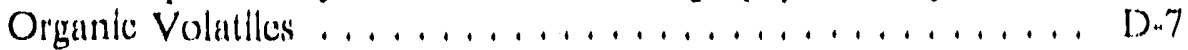

D.2.3 Semivolutile Organic Components of Aqueous Semples . . . . . D.7

D.2.4 Semivolatile Organic Components of Sludge Samples . . . . . . D.8

D.2.5 Loach Test of Organic Layer Sampler. . . . . . . . . . . . . D - 8

D.2.6 Chemicals, Surrogates, Spikes, and Internal Standards . . . . . D D.9

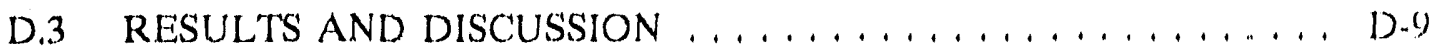

D.3.1 Volatile Organic Components of Aqueous Samples . . . . . . . . D-9

D.3.2 Direct Aqueous Injection Cas Chromalography for Major

Organic Volatiles . . . . . . . . . . . . . . . . . . D D-10

D.3.3 Semivolatile Organic Components ol' Licyudds and Sludges . . . . D-11

D.3.4 Accountability for Total Organic Carbon in Samples . . . . . D D-12

D.3.5 L.ach Test of Organic Sampler . . . . . . . . . . . . . . D 1.3

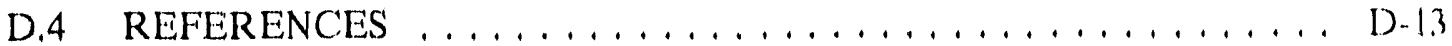




\section{D.1 IN'IRODUC'IION}

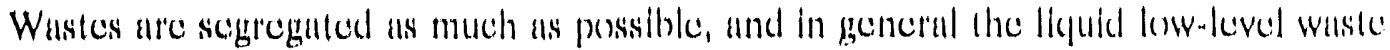

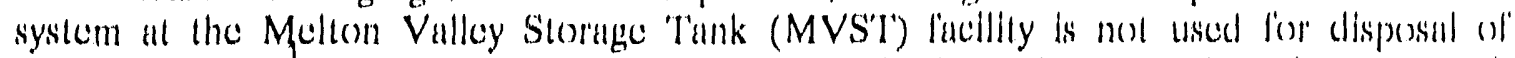
organic solvents. However, the wasle aceeptance eriteria are based on the primary hazard.

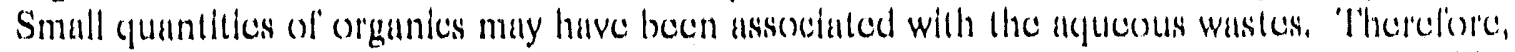
licpuid and sludge samples from throe lanks (W.24, W-25, and W-31) at lhe MVS'l' linellly

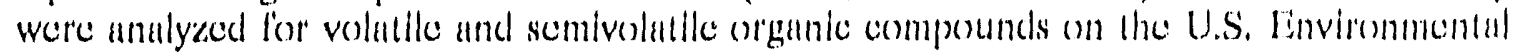

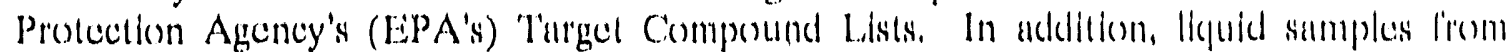
MVST lanks W-29 and W.30 were characteriaced in support of a planned campuign 10 remove supernatant liquid from these tanks and solidify the waste in a cement mantix.

The metheses of anulysis are detalled in the EPA solid waste manual, SW-846. ${ }^{2}$ 'the EPA melhods were not designed lor radionetive hazardous (mixed) waste samples. Modilications for analyzing radionetive samples were develonged and lested during sladiess of the inactive waste lanks at ORNL. The appreach taken lore the determinalten al' largeled organic eompounds in the sumples was to prepare deconlaminaled extracts in an radiation contaminalion-zoned laboratory al the High Radialion level Analytical Laboratory (Building 2(20). The extracts were then transferred to the conventional organic analysis laboratory (Building 45(K)S), where the quantitative mestsurements were pertermed, The preparation methods followed EPA SW-846 melhodology as closely as possible." Some modifications, such as reducing the sample size, wele necessiary to minimize radiation exposure to both the field sampling crew and the analyst. Doviations lirem the methed required by the radionative nature or other characteristics of the samples were documented. All quantitative measurenents were perlenmed using the EPA Contrate Laboralory Program (CLP) methodologics which are equivalent 10 SW-846 Method 8240 and Methex 827() .

The Inorganic and Physical Anulysis Group received and logged in the samples, prepared composite sludge samples for each lank, and transferred licpuid samples and alicyusts of the sludge to the Separalions and Synthesis Group for organic analytical preparalion. Most quanlitative measurements were made by the Organic Analysis (iroup: however, direce afpecous injection gils chromatography (DAICC) was dene by the Separations and Synthesis Group. All sample translers were aceompanied by chain-oflcustexdy documentation.

Results of the characterization of organic chemicals are summarized in Sect. 4.3. A moredetailed discussion of the results and briel descriptions of the methexls are presented in this appendix. 


\section{D.2 METHIODS AND MATERIALSS}

\section{D.2.1 Volatile Organic Components of Aquesous Samples}

The following is a bried deseription of the analysis of organic voluliles in radiondetive:

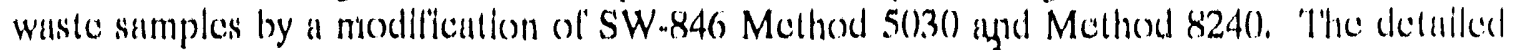
description of the procedure has been reported previously. All samples were received in Building 2026 and externally monitored for gamma radiation levels prior fo processing. The samples were contained in $25($ ) $\mathrm{mL}$ wide-mouth jus with appreximalely 1.5 lo $30 \mathrm{ml}$. of hoadspace in the jar. The sampling of the liquid contents for analysis of targeled organic volatiles was always pertormed at the first opening of the jar'. Sparging of the samples lor volatile organic components was accomplished in a radiation contaminationzoned glove box. Prior to the opening of the sumpla, the sparging assembly system was lasted for f'ree flow of nitrogen gas through the sampling head and trap. The sample bottle was opened, and a 5 -mL aliçuot was placed in a $4(2) \mathrm{mL}$ volatile organic analysis (VOA) vial; then $10 \mu \mathrm{L}$ of the CLP purgeable surrogate standard (Sect. D.2.6) containing $25 \mathrm{\mu g} / \mathrm{mL}$ of each component was added to the sample. The VOA vial was atlached (o) the sampling head, and the sample was sparged for $11 \mathrm{~min}$ at $30 \mathrm{~mL} / \mathrm{min}$ with nitregen. The nitrogen and sparged volatile organics passed through a capillary Telton lubing. and the volatile organic compounds were collected in a solid sorbent trap (EPA Melhod 624) allached externally to the glove box. A second 5 -mL alicuot plus purgeable surrogate was sparged for a back-up sample.

Alter the traps had been removed from the glove box and sealed, they were monitored for radioactivity with standard probe and smear lechniques bolore being transfiered to a nonradioactivity-zoned laboratory for quantitation of volatile organics by GC/MS Melhod 8240.

An integral eomponent of methexd performance evaluation was the acklition of purgeable surrogate standard to all samples and to a water blank with each sel of simple preparalions. A matrix spike and a malrix spike duplicale were prepared will ench sample group.

In the nonradioactivity-zoned laboratory, the traps were thermally desorbed (similar (1) Method 5040) through $5 \mathrm{~mL}$ of distilled water containing CLP purgeable internal standard mix. Both the thermally desorbed organie compounds and the internal standirds were colleced in the internal trap of a Tekmar liquid sample concentrator. 'The orginic components were desorbed from the trap by healing and were swept by a helium llow onto a gas chromatography column localed in a Hewlell-Packard GC/MS. The analyles were detected by the matss spectrometer, which was checked daily against a calibration curve. Reporting limits were 5 to $10 \mu \mathrm{g} / \mathrm{L}$. 


\section{D.2.2 Dircet Aquerous Injection Gas Chromatography for Major Organic Volatiles}

Several highly polar, water-soluble organic compounds (c,g, methyl and sthyl alcohol) are poorly detected by purge-and-arap methods. Therefore, DAIGC pallerned "Ilter SW-846 Mothod 8015 was used to analyze sample alleguts that had beor placed in 1.5 - $\mathrm{mL}$ vials when the sumples were litrst opened in the glove box. Injectlons of $3 \mu \mathrm{L}$ were made into a gas chromatograph equipped with a $3.2-\mathrm{mm}-\mathrm{OD}$ stainless stecl column packed

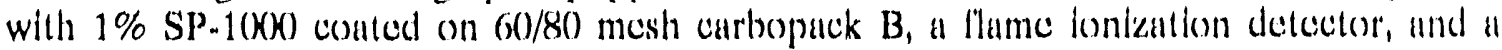
reporting Integrator. The column packing is the same as that used for the detection of volatiles by GC/MS. The llow rate of the hellum curricr gas was 30) $\mathrm{mL} / \mathrm{minh}$. The initial column temperature of 7()$^{\circ} \mathrm{C}$ was held for 2 min, followed by a programmed $16^{\circ} \mathrm{C} / \mathrm{m} / \mathrm{n}$ increase $10220^{\circ} \mathrm{C}$ and a linal isothermal hold of $16 \mathrm{~min}$. The inlet and detector temperatures were 150 and $250^{\circ} \mathrm{C}$, respectively.

The chemical components were quantified by comparing peak areas of the surnple with peak areas of external standards at four concentrations ranging from 4 lo 40$) \mathrm{mg} / \mathrm{L}$. Distilled-in-glass water blanks and matrix spikes (Seot. D.2.6) were analyzed with each group of samples.

The GC conditions were slightly modified from Method 8015, and the callibration was performed daily with standards of four conecntrations. Mothod 8015 suggests a weckly calibration using five concentrations of standards and a daily calibration with a single standard. The detection limit under the conditions described was 1 to $2 \mathrm{mg} / \mathrm{L}$.

\section{D.2.3 Semivolatile Organic Components of Aqueous Samples}

Semivolatile organic compounds can be extracted from aqueous solutions by the liquid-liquid extractions procedures described in SW-846 Method 3510. However, direcel application of this method to the extraction of mixed waste would result in contamination of the GC/MS equipment and exposure of laboratory staff' mombers to unsale levels of radiation. Modifications of the semivolatile organic compound analysis (SVOA) method for use with mixed waste and the subsequent analysis of an extract of the radioactive wastes have previously been reported. ${ }^{4}$ Briefly, the samples were checked for pH using wide-range $\mathrm{pH}$ paper. Aliquots of CLP acid and base/neutral surrogate standards (Sect. D.2.6) were added to a 20-mL sample that was extracted three times with 5 -mL volumes of methylene chloride. The methylene chloride was removed with a Pasteur pipette afler each extraction and put through a Separator $X$ filter unit to remove trace amounts of water; then the organie solvent aliguots were eollected and pooled. Each sample wass extracted at two pH levels: $>10$ and $<2$. The extracts from the acidic and basic pH were pooled and concentrated to approximately 2 to $4 \mathrm{~mL}$ by a flow of dry nitrogen gits. The sample extracts were further concentrated $101 \mathrm{~mL}$ in a volumetric flask and then transferred to a crimp-top vial and spiked with CLP internal standard mix. One sample containing the SVOA matrix spike was extracted in duplicate with each daily preparative simple set. 
Following extraction and concentration, each sample was screened for gross alpha and heta/gamma radinactivity, and the vials were checked for radioactive contamination by standard probe and smear techniques prior to transfer to a conventional GC/MS laboratory for quantitation of the semivolatile components. In virtually all cases, the samples were depleted of radioactive contamination.

All extracts were screened by GC qualitatively against a multiple-component (5) ppm) GC/MS daily calibration standard to identify those which might need dilution prior to GC/MS analysis. Final identification and quantitation of the semivolatile organics were performed by GC/MS as described in SW-846 Method 8270. The reporting limits for the aqueous sample aliquots are 250 to $1300 \mu \mathrm{g} / \mathrm{L}$.

\section{D.24 Semivolatile Organic Components of Sludge Samples}

Due to the high levels of radioactivity and limited volumes of sample, the sludges were extracted for semivolatile organic compounds using a modification of SW-846 Method 3550 . Samples with a radioactivity level greater than approximately $500 \mathrm{mR}$ were extracted in a hot cell. All other samples were extracted in a radiochemical hood.

Approximately 3 to $4 \mathrm{~g}$ of sludge slurry was weighed into a 250 -mL beaker and spiked with CLP base/neutral and acid surrogate standard solutions. The slurry was stirred, and approximately 10 to $20 \mathrm{~g}$ of anhydrous sodium sulfate was slowly mixed into the sample. The sludge mixture was extracted three times with $40-\mathrm{mL}$ aliquots of methylene chloride/acetone $(1 / 1, \mathrm{vol} / \mathrm{vol})$ using a $350-\mathrm{W}$ ultrasonicator filled with a $1.5-\mathrm{cm}-\mathrm{OD}$ horn. Each aliquot was extracted at a $50 \%$ duty cycle and a power level of 5 for 3 to 5 min. After each extraction, the supernatant liquid was decanted into a 60)- or 150)-mL mediumporosity, sintered glass funnel, and the extracts were filtered and eollected as a single sample. The combined extract was concentrated to $1 \mathrm{~mL}$ by nitrogen blowdown, placed in a crimp-top vial, and spiked with internal standard (Sect. D.2.6).

A hlank was prepared by extracting reagent-grade sea sand. One sludge containing matrix spike was extracted in duplicate with each preparative set of samples. All samples were qualitatively screened by GC for semivolatile organic components and checked lor radioactive contamination prior to being transferred to the conventional GC/MS laboratory. The reporting limits varied from $25(x)$ to $17,(0) 0 \mu \mathrm{g} / \mathrm{kg}$, depending on the exact mass of sludge extracted.

\section{D.2.5 Leach Test of Organic Layer Sampler}

A polyvinyl chloride (PVC) organic sampler was tested for leaching of trace organic compounds by filling the collector with $250 \mathrm{~mL}$ of hexane for $24 \mathrm{~h}$. After $24 \mathrm{~h}$, a $1-\mathrm{mL}$ aliquot of the hexane was diluted to $10 \mathrm{~mL}$ with methylene chloride and subsequently analyzed by GC/MS for targeted organic semivolatile components (Waste Dilution Method 3580 followed by GC/MS Method 8270). 


\section{D.2.6 Chemicals, Surrogates, Spikes, and Internal Standards}

All organic solvents were of high purity and were obtained from Burdick and Jackson Laboratories, Inc. (Muskegon, MI) or J. T. Baker, Inc. (Phillipsburg, NJ).

The VOA CLP purgeable surrogate standard mix contained toluene-d8, 1,2dichloroethane-d4, and 4-bromofluorobenzene. The purge-and-trap matrix spike contained 1,1-dichloroethene, trichloroethene, benzene, toluene, and chlorobenzene.

The standards and matrix spike compounds for DAIGC contained methyl alcohol, ethyl alcohol, acetone, isopropyl alcohol, allyl alcohol, 2-butanone, isobutyl alcohol, n-butyl alcohol, and 4-methyl-2-pentanone.

The SVOA surrogate standard contained nitrobenzene-d5, 2-fluorobiphenyl, p-terphenyl-d14, 2-fluorophenol, phenol-d5, and 2,4,6-tribromophenol. The matrix spike solution for SVOA organic analysis contained phenol, 2-chlorophenol, 1,4-dichlorobenzene, $\mathrm{N}$-nitroso-di-n-propylamine, 1,2,4-trichlorobenzenc, 4-chloro-3-methylphenol, acenaphthene, 4-nitrophenol, 2,4-dinitrotoluene, pentachlorophenol, and pyrene. The SVOA internal standard contained acenaphthlene-d10, chrysene-d12, 1,4-dichlorobenzene-d4, naphthalened8, perylene-d12, and phenanthrene-d10. All spikes and standards were obtained from Supelco, Inc. (State College, PA).

\section{D.3 RESULTS AND DISCUSSION}

The EPA Target Compound Lists of volatile and semivolatile organic compounds are given in Sect. 4.3, Tables 4.3.1 and 4.3.2. The reporting limits, the concentrations above which the response of the GC/MS for a calibrated range of concentrations is linear, are included in the tables for the volumes and/or weight of the MVST samples analyzed.

\section{D.3.1 Volatile Organic Components of Aquoxus Samples}

The results of the analysis of the MVST liquid waste samples for volatile organics are shown in Table 4.3.3. The table lists only the volatile organic compounds whose possible presence was indicated by the GC/MS analysis. The targeted volatile compounds, methylene chloride, acetone, and toluene, were observed in each of the tank samples. Since these compounds were also observed in the blanks at similar concentrations, they probably cannot be attributed to the aqueous samples. EPA SW-846 requires that up to 20 unidentified compounds be reported as tentatively identified compounds (TICs) if volatile organic compounds other than those on the Target Compound List were detected by GC/MS. These compounds are identified solely by mass spectrum, and quantitation is based on the response factor of the nearest internal standard present in the gas chromatogr.m. TICs were observed in samples W25-L.2, W29-L1, W30-L1, and W30-L4, and no compounds with similar GC retention time or mass spectra were observed in the 
blank. One compound, trichlorofluoromethane, was identified as a TIC at concentrations up to $36 \mu \mathrm{g} / \mathrm{L}$ in four of the tanks. The water blank contained $10 \mu \mathrm{g} / \mathrm{L}$ of this eompound.

The addition of purgeable surrogate standard to the samples in the glove box permitted the evaluation of recoveries through the entire procedure, sampling and spiking within the glove box, purge-and-trap, and thermal desorption purge-and-trap GC/MS. Generally, recoveries of the purgeable surrogate standards in the glove box were comparable with the quality control aceeptance limits specified by EPA Method 8240 for grcundwater samples. The percent recoveries of the VOA surrogates were as follows: toluene-d8 (84 \pm 19$)$; 4-bromofluorobenzene $(70 \pm 33)$; and 1,2 dichloroethane $(86 \pm$ 11). The QC acceptance limits for these compounds in groundwater are 88 to 110, 86 to 115 , and 76 to 114 , respectively. In three cases, the recoveries of 4-bromolluorobenzene were significantly below the limits for groundwater. This is probably due to the necessity of work within the glove box and the subsequent transfer of the traps to the GC/MS laboratory for analysis as well as a matrix effect. Sinee the most volatile compound had the highest recoveries, it is possible that the other compounds were not as completely purged from the off-line trap. The recoveries of the matrix spikes were usually within the ranges specified by the EPA CLP guidelines for groundwater. The pereent recoveries were as follows: 1,1-dichloroethene $(134 \pm 30)$; trichlorocthene $(118 \pm 24)$; benzene $(120 \pm$ 26); toluene $(98 \pm 27)$; and chlorobenzene $(82 \pm 16)$. The CLP quality control acceptance limits for the matrix spikes are 61 to 145,71 to 120,76 to 127,76 to 125 , and 75 to 130, respectively. A Quality Control Acceptance Limit for matrix spikes is not listed in EPA SW-846.

\section{D.3.2 Direct Aqueous Injection Gas Chromatography for Major Organic Volatiles}

No organic volatiles were detected by DAIGC of any of the MVST tank samples. The detection limits for the compounds listed in Sect. D.2.2 were 1 to $2 \mathrm{mg} / \mathrm{L}$. Matrix spike (Sect. D.2.6) recoveries were very good - greater than $85 \%$ for each of the compounds in all assays. Although there are no EPA quality control aceeptance limits for this procedure, the recoveries are typical of previous performance.

During the course of the analysis of the tank liquids, the project management requested an evaluation of DAIGC for the determination of 0.25 and $0.5 \mathrm{mg} / \mathrm{L}$ of methanol and pyridine, respectively. To permit this evaluation, the procedure was modified by changing the volume of sample injected, changing the column temperature program, and increasing the sensitivity. These changes resulted in delection limits for methanol at $0.5 \mathrm{mg} / \mathrm{L}$ and pyridine at $1.0 \mathrm{mg} / \mathrm{L}$; however, the sizes and shapes of the peaks and the sample blank level did not permit accurate quantitation. Quantitative determination of these lower concentrations of methanol and pyridine would require some development of the present procedures. One approach that should be considered, if these quantitation limits are needed, is the use of a more efficient wall-coated fused silica "Megabore" GC column rather than the conventional packed column that was used during the MVST and inactive tank sample analyses. 


\section{D.3.3 Semivolatile Organic Components of Liquids and Sludges}

Table 4.3.4 shows the results of the analyses of the MVST liquids and sludges for semivolatile organics. Only a few organies were identified, for example, benzoic acid, naphthalene, 2-nitrophenol, phenanthrene, diethylbenzene, dimethylbenzene, nitrophenols, and phthalates. These compounds were also observed in studies of the inactive tanks. 3,4 These organics are compounds or degradation products of organic chemicals that are known to have been used in various plant processes over the years. The compounds constituting the greatest organic mass of semivolatiles were the phthalates, which are almost ubiquitous in nature. As further confirmation of their ubiquitous nature, phthalates were also present in relatively high concentrations in the water and sand blanks. The majority of the recovered semivolatiles were TICs: unknown, unknown hydrocarbons, and unknown phthalates. It is interesting that tributyl phosphate (a common extractant) was only detected in the sludge of tank W-31. If it was present in the waste streams added to the other tanks, it could have decomposed due to unique chemical or radiolytic interactions in the highly alkaline conditions.

Recoveries of the surrogate standards were generally within the quality control aceptance limits specified for groundwater samples by EPA SW-846. The percent recoveries for the SVOA surrogate spike were as follows: nitrobenzene-d5 $(65 \pm 21)$; 2-fluorobiphenyl (73 \pm 16$)$; p-terphenyl-d14 (145 \pm 26$)$; phenol-d5 (47 \pm 41$) ; 2$ fluorophenol $(33 \pm 30)$; and 2,4,6-tribromophenol $(99 \pm 33)$. The QC acceptance limits for these compounds are 35 to 114,43 to 116,33 to 141,10 to 94,21 to 100 , and 10 to 123, respectively, but their applicability to waste samples is unknown at present. The large variation of the phenols was due, at least in part, to a matrix effect in tank samples W-25 and W-31. No phenol surrogates were recovered in these samples. Matrix spike recoveries, with the exception of the highly variable recovery of the acidic phenols, were within the quality control limits defined by the EPA Contract Laboratory Program. The pereent recoveries of the SVOA matrix spikes were as follows: phenol $(36 \pm 20)$; 2-chlorophenol $(33 \pm 9)$; 1,4-dichlorobenzene $(30 \pm 7)$; N-nitroso-di-n-propylamine $(68 \pm 10) ; 1,2,4$ trichlorobenzene $(38 \pm 3) ;$ 4-chloro-3-methylphenol (47 \pm 35$)$ acenaphthene $(58 \pm 3)$; 4-nitrophenol $(88 \pm 16) ; 2$,4-dinitrotoluene $(90 \pm 10)$; pentachlorophenol $(85 \pm 27)$, and pyrene $(89 \pm 6)$. The QC acceptance limits for these compounds are 26 to 90,25 to 102,28 to 104,41 to 126,38 to 107,26 to 103,31 to 137 , 11 to 114,28 to 89,17 to 109 , and 35 to 142 , respectively. We do not know the reasion for the poor recoveries of the matrix spike acid phenols during these studies and those of the inactive tanks, ${ }^{3,4}$ but two possible explanations are proposed: (1) the adjusted pH of the final extract was not sufficient to permit quantitative extraction of the smaller acidie phenols, or (2) the phenols were decomposed by the basic $\mathrm{pH}$ of the waste samples. Decomposition of the phenols is the more likely cause of their poor recovery. All of the MVST samples were strongly basic due to the treatment of these wastes with alkali. It has been demonstrated by the Organic Analysis Laboratory that the phenolic organics are best recovered from acid solution or from acidification of basic solutions that were within a relatively narrow $\mathrm{pH}$ range of approximately 10 to 11 (the phenolic spikes tended to decompose at higher pH levels). A further complication is the length of time that these compounds are retained under highly basic conditions. "The time required for extraction 
may have been too long due to problems, such as foaming, that have been described previously.

As agreed at the start of the project, polychlorinated biphenyls (PCBs) were not specifically determined in the analyses of the lank liquids and sludges. However, individual PCBs would be detected and estimated as TICs in the semivolatile organic eompound analysis. The estimated reporting limits for individual PCBs (not Aroclor mixtures) were $2.5 \mathrm{mg} / \mathrm{L}$ for aqueous liquids and 13 to $17 \mathrm{mg} / \mathrm{kg}$ for sludges (depending on whether 4 or $3 \mathrm{~g}$ of sludge was extracted). The mass spectral fragmentation pattern arising from the chlorine isotopes is easily identified, and PCB cogeners present in the TICs would have been identified. Detection limits of Aroclors (mixtures of PCBs) would be much higher since each component would have the same reporting limit.

\section{D.3.4 Accountability for Total Organic Carbon in Samples}

The samples were analyzed for total organic carbon content (TOC) by the Inorganic and Physical Analysis Group (Sect. 4.2). The resulting values were then used to calculate the pereent of the TOC eontributed by the volatile and semivolatile organic eompounds. No correction was made for contributions from the blanks; therefore, the accountability factor is exaggerated. The calculations indicate that volatile (Table 4.3.3) plus semivolatile (Table 4.3.4) organic compounds determined by the modilied SW-846 methods comprise only $4 \mathrm{to} 14 \%$ of the TOC in the aqueous and/or sludge samples from the MVSTs. These results are similar to those obtained in studies of the inactive tanks at ORNL.

The organics that are not accounted for by EPA methods may consist of highly polar, water-soluble, and possibly polymeric compounds arising from radiolysis or chemical degradation, or compounds originally present in the waste. For example, low-molecularweight organic acids/salts such as oxalate, acetate, and butyrate are not detected by the EPA methods. In a preliminary study of the organic matter in the inactive tank samples for another project, the quantity of the TOC that could be aceounted for was signilicantly increased by treating the samples with silylating or alkylating reagents so that compounds not normally analyzed by GC became more volatile or perhaps more thermally stable and could be detected and/or separated for analysis by GC. The TOC aceounting in the aqueous waste liquids was increased from about $2 \%$ to $25-100 \%$ for three inactive waste lank samples by derivatizing the dried residues and analyzing by $\mathrm{GC}$. Many of the nonregulatory compounds identified by this procedure were chelators, such as oxalates or ethylenediaminetetraacetic acid and its decomposition products, or tributyl phosphate and its degradation products.

We feel that many of the organic compounds that contribute to the TOC in the MVST tanks are of the non-regulatory type. Identification of these compounds would require additional development and application of analytical methods. 


\section{D.3.5 Leach Test of Organic Sampler}

Analysis of the hexane used for determination of the leaching of semivolatiles from the organic sample collection device showed no semivolatile organic compounds, indicating that the PVC material used for the collector was a satisfactory construction material. The reporting limits for the leach test were 50 to $250 \mu \mathrm{g} / \mathrm{L}$.

\section{D.4. REFERENCES}

1. ORNL Environmental Protection Manual, Procedure EPM-18.(), "Liquid Waste Disposal," staff of the Department of Environmental Management, Oak Ridge National Laboratory, Oak Ridge, Tenn.

2. U.S. Environmental Protection Agency, Test Methods for Evaluating Solid Waste, SW-846, 3rd ed., U.S. EPA Office of Solid Waste and Emergency Response, Washington, D.C. 1986.

3. B. A. Tomkins, J. E. Caton, M. D. Edwards, M. E. Garcia, R. L. Schenley, L. J. Wachter, and W. H. Griest, "Determination of Regulatory Organic Compounds in Radioactive Waste Samples. Volatile Organics in Aqueous Liquids," Anal. Chem. 61, 2751-2756 (1989).

4. B. A. Tomkins, J. E. Caton, G. Scott Fleming, M. E. Garcia, S. H. Harmon, R. L. Schenley, C. A. Treese, and W. H. Griest, "Determination of Regulatory Organic Compounds in Radioactive Waste Samples. Semivolatile Organics in Acjucous Liquids," Anal. Chem. 62, 253-257 (1989).

5. R. L. Schenley and W. H. Griest, Investigation of the Organic Malter in Inactive Nuclear Waste Tank Liquids, ORNL/ER-12, 1990. 


\section{APPENDIX E}

SAMPLING PROCEDURES - MELTON VALLEY AND EVAPORATOR STORAGE TANKS FOR WASTE CHARACTERIZATION 
E-3

\section{APPENDIX E CONTENTS}

Procedure SC-001 General Sampling Procedure for Liquid Low-Level Waste Stornge Tanks

Procedure SC-002 Vacuum Pump Liquid Sampling Procedure

Procedure SC-(003 Solt Sludge Sampling Procedure

E-19

Procedure SC-004 Hard Sludge Sampling Procedure

E-23

Procedure SC-005 Decontamination of Sampling Equipment

1:-27 Procedure

Procedure SC-006 Sampling Custody

E-29

Procedure SC-007 Organic Layer Sampling Procedure

$\mathrm{E}-3.5$

Procedure SC-008 Archive lor Liquid Low-Level Waste Samples

$[-39$ 


\section{SAMPLING FOR WASTE CHARACTERIZATION}

\section{SAMPLING PROCEDURES}

Approved by:
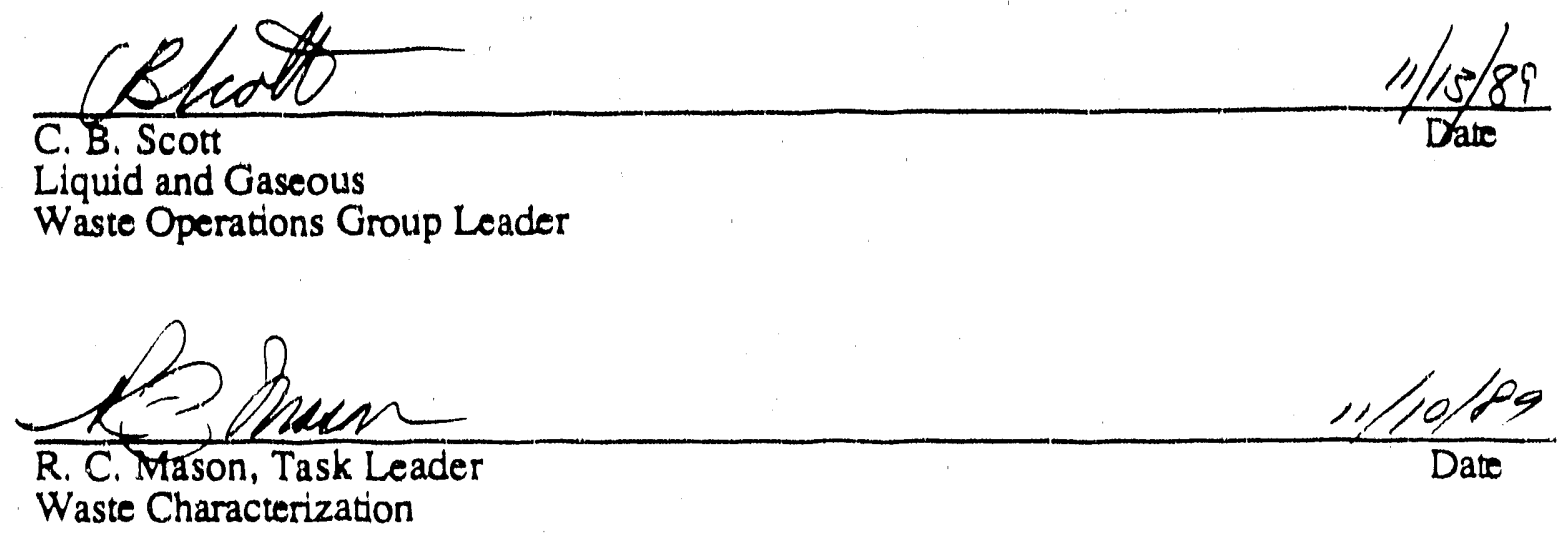

CHBroun 2 .

$11 / 14 / 89$

C. H. Brown, Program Manager

Date

Liquid Low-Level Waste Solidification

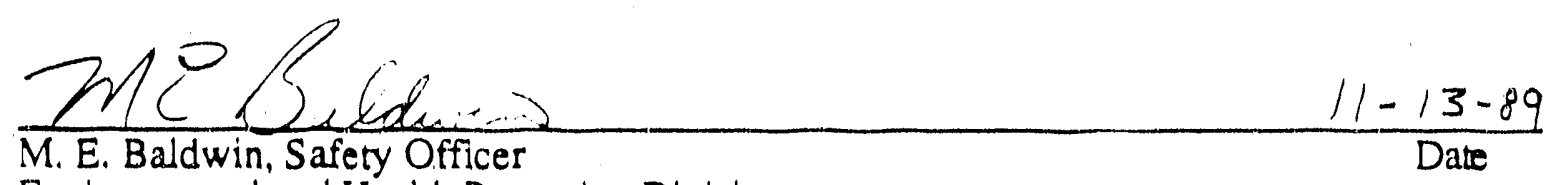

Environmental and Health Protection Division 


\section{Procedure SC-(0)1 Gencral Sampling Procedure for Liquid low-lovel Waste Storage 'Tanks}

Eight low-mevel waste stornge tanks at ORNL are to be sampled and analyzed to determine major chemical constituents, radionuclides, organics, possible constituents listed as hazardous under RCRA, and general waste characteristics. This procedure rovers sample collection actlvities which are common to all of the tanks. The two groups of tanks that will be sumpled are the Melion Valley Storage Tanks (MVS'I's) and the Evaporator Concentrate Storage Tanks. A Radiation Work Permit (RWP) is reguired prior to field activities near any of the waste storage tanks (Fig. 1-1). Sampling is to be conducted by trained chemical operators in "full dress out" protective clothing for handling radionctive wastes. Sampling activities shall be continuously monitored by radiation protection personnel. Air simpling is recpuired. Electrical power (110 V) should be provided at the site to operate the radiation protection air sampler. Sampling shall be conducted during dry wenther.

Pastic sheeting, absorbent paper, and where appropriate pans shall be placed to confine the radionctive materials and prevent contact with the vault roof and other clean surfaces. Waste rags and materials used to wipe down handles and sampler assemblies should be placed in a plastic bag. Spill containment and clean-up materials shall be maintained and readily available within the work area.

Extremity dosimeters (finger rings) are recpuired for all employees that directly handle the filled sample containers. All exposures of the employees involved in this task should be kept segregated from their overall exposures from day-to-daly activities (by use of recording pocket meter readings) so that the overall exposure information can be further utilized in luture waste tank projects.

The sampling crew shall have training in handling low level, TRU, and mixed wastes, in the use of respirators, and in the project specific procedures.

Labels should be attached to the sample jar and to the plastic bags and the container which will be used to package the sample before the sample is collected. Preprinted labels will be provided by J. J. Ferrada.

Care should be taken to keep the samples upright during handling and transport.

\section{Presimpling}

1. If wastes have recently been transferred into the storage tank, the tank contents should be acrated to agitate and mix the liquid wastes before sampling. The air spargers should be lefi on for at least 24 hours (1 day). Omit this step if wastes are allecaly mixed.

2. After mixing, turn off the air spargers which agitalle the tanks and allow the solids to selle for at least 6 days before measuring the interface or collecting samples. Record on the log sheet (Fig. 1-2) under comments the date the air spargers were turned off.

3. Sampling eefupment musl be cleaned and allowed to dry prior to each use per Procedure SC-(x)5, l'xecontamination of Sampling layupment Procedure. Some new exuipment must be cleaned prior to the first use. This eyupment is spelled out in Procedure SC-()().5. 
li-s

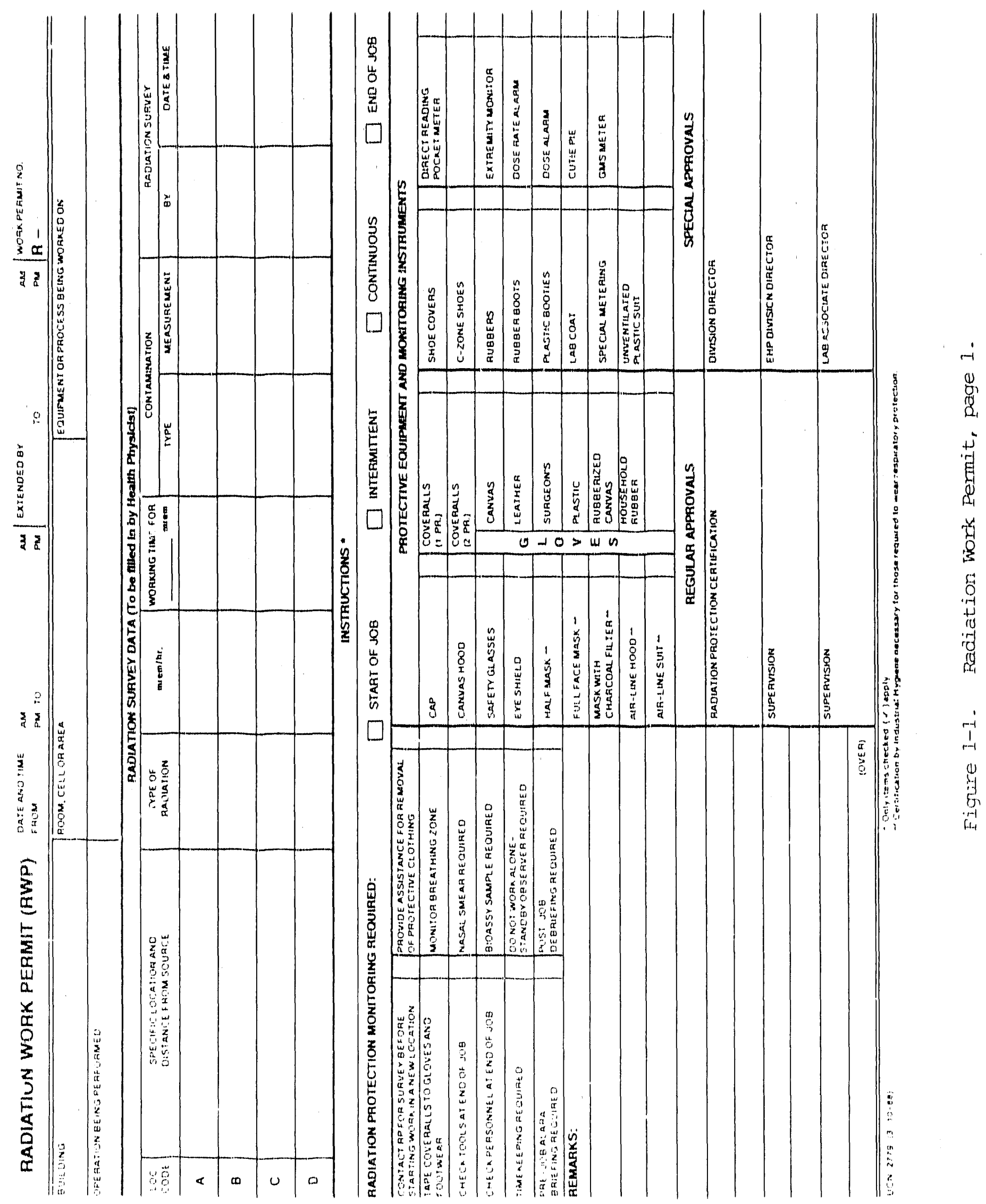


(i.)

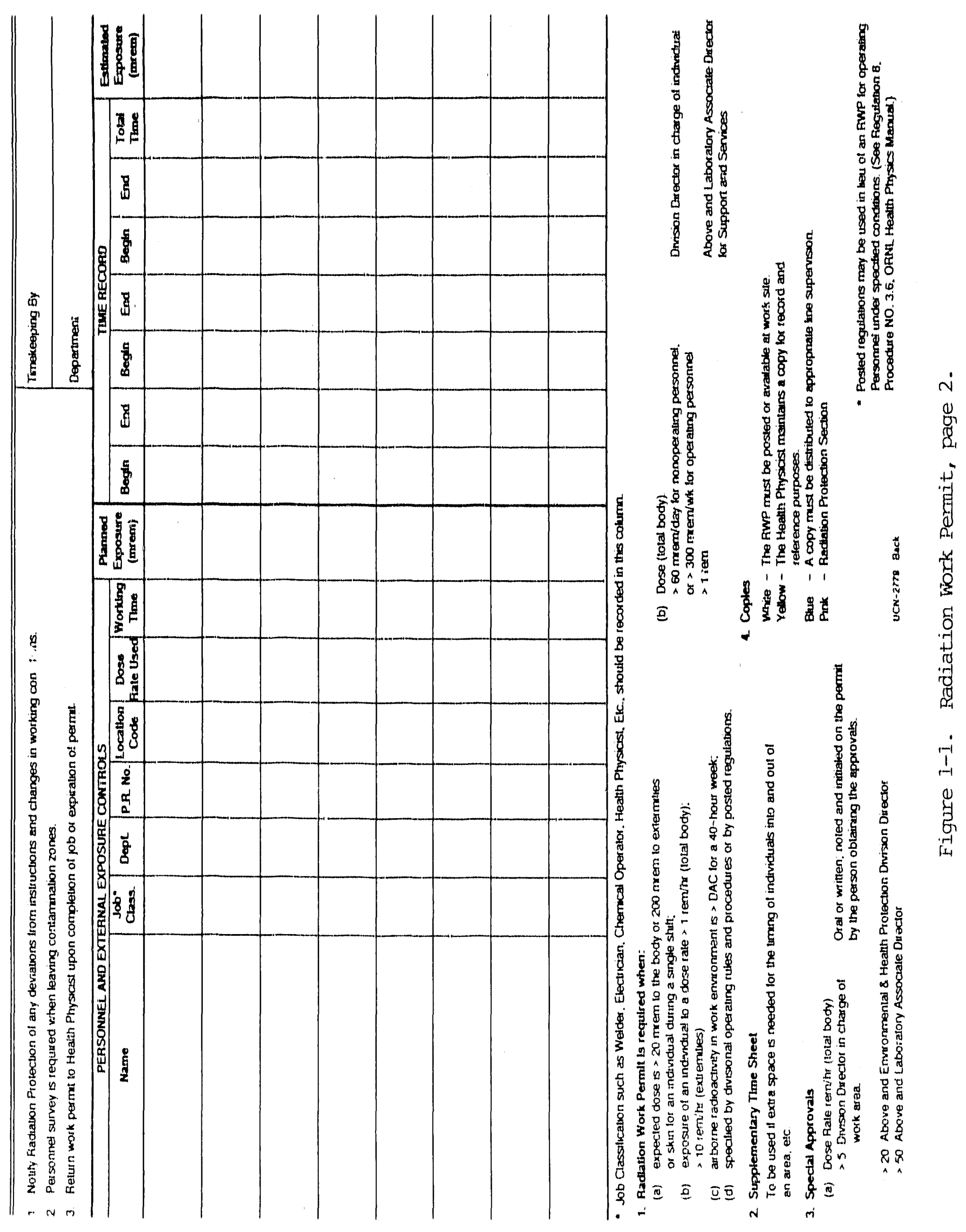



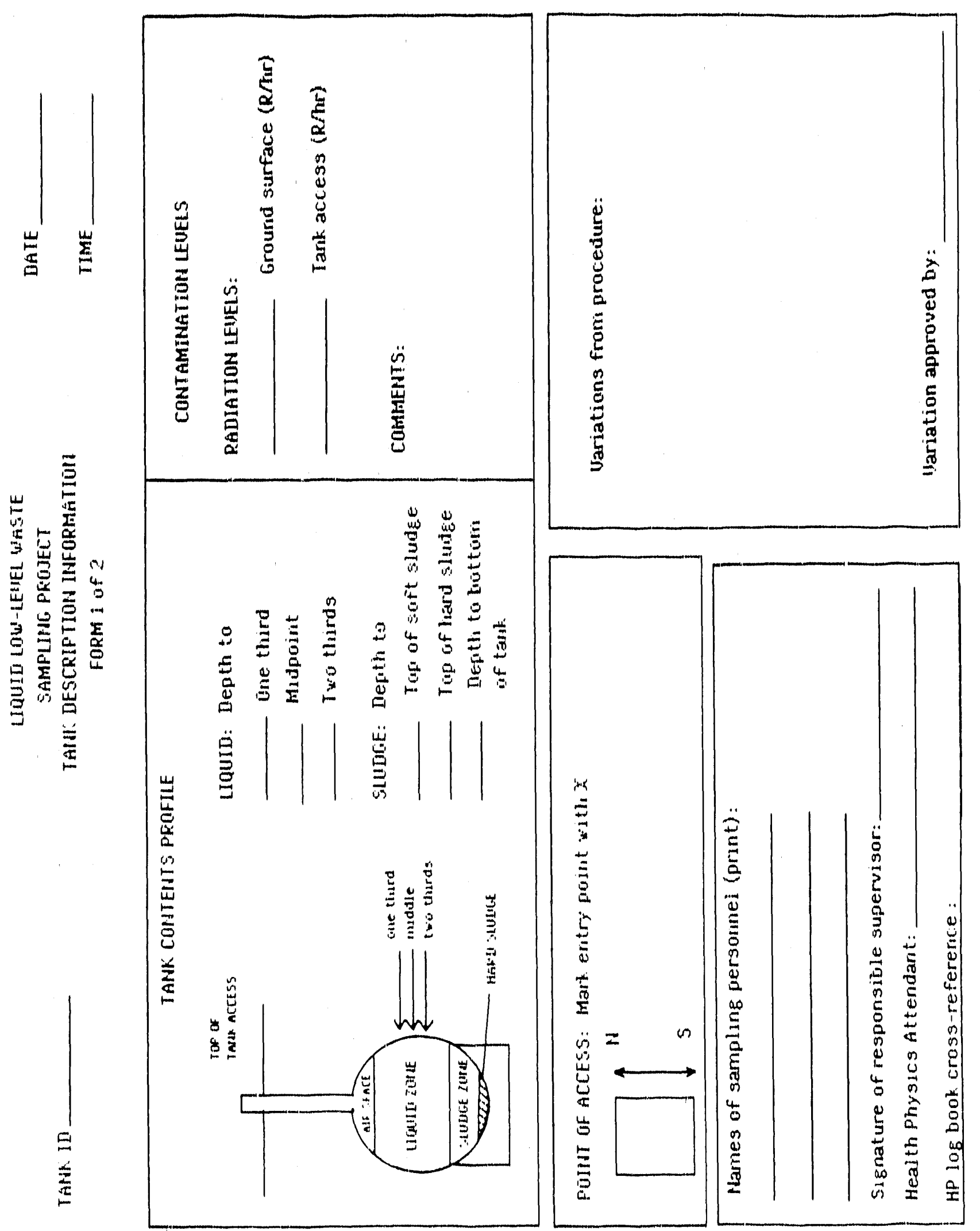
4. A presampling survey will be condected betore collecting the simmples. At this thme

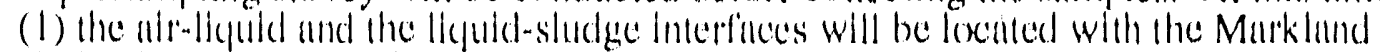
sludge level delector, thus estublishing the depth of the supermatunt licyuld, and (2) a rough estimale of the beta-gamma rallation level will be made. 'The presimpling survey should be conducled all least one day in advance of sample collection lo allow time for the dlsturbed solids to settle.

11. Have the Instrument and Controls (I\&C) Iechnichan disconneet the licpuld level inserumentation. Open the tank anecesss. Radiation levels should be monitored as the aceess ls opened.

b. Measure the air-liguid and licpuid-sludge interfaces. Ruise and lower the sludge level detector slowly and carefilly to minimize the disturbance of the licuid-stadge interliace and any stratified liguld layers. Check also for the presence of immiscible or stratified lieguid layers such as an organle layer and measure any interficess which are observed.

c. Record in the logs sheet (Fig. 1-2) the distance from the top of the tank opening to the lieguid surfice and the distance from the lop of the lank opening to the licyude-sludge interfice. If immiscible or strablied layers are observed record the distariec from the top of the tank opening to the interfice under comments.

d. Wipe down the delector head and cable with spraly cleaner and rags as described in Procedure SC. ()()5.

e. Close the lank alcesss.

f. The information will be evaluated and linal plans mate for collecting samples. 'This will include a review of the radiation protection measures which will be needed.

g. Prepare sumpling eyuipment.

\section{Sumple Collection}

5. Open the tank access. Radtatton levels should be monitored comtinuously as the aceess is opened. Record the radiation level at the tank aceess on the data collection form.

Sumples should be colleceded in the order (1) alyuenus liepuid samples, (2) organic layer samples (if present), and (3) sludge samples.

6. Take the first licyuid sample at the one-third level below the air-liguid surface. Refer' to the liguid simpler operating instructions in Procedure SC.()(1)2. The botlle should be labeled before collecting the simple. Repeat the simpling at the once half and then all the twe-thirds supermate depth measured from the ofop of the lieguid as described in the Procedure SC-()(2). After a lieguid simple has heen taken, prepare the simple as follows:

a. Scial the bonle.

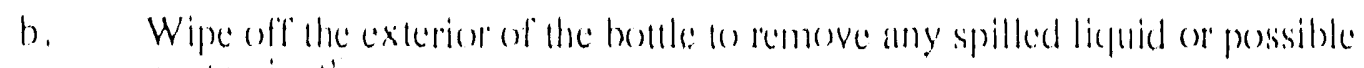
conliamination. 
Rev. 1

c. Place the bottle in plastic bag(s) and seal the bag with tape. Have the HP measure the radiation level of the sample. Then place it in a lead pig for transport. Label the container with information on the radiation level. The lid oi the leadi pig should have a wire handle.

d. Record sample data on page 2 of the sample collection form (Fig. 1-3). Complete chain-of-custody form for the sample.

c. Have the HP monitor the radiation level and tag with the "HP" tag (Radiation Hazard Materials Transfer Tag). If the radiation level at the surface of the pig is $100 \mathrm{mrem} / \mathrm{h}$ or less, the sample will be transported in the pig.

f. In the event that the radiation level at the outer surface of the pig should exceed $100 \mathrm{mrem} / \mathrm{h}$, place the pig in a paint can with crumpled plastic for padding and then into the stainless steel transport carrier.

7. The instructions for organic layer sampling in steps 7-9 are for the most probable scenarios which are either a relatively thin or no organic layer over the aqueous layer. If a thick organic layer (approximately 10 inches thick) is detected with the Markland detector during the presampling survey omit steps 7 to 9 and follow the alternate directions in step 10 .

The bottom opening sampler developed for sampiing soft sludge will be used to collect a column of liquid at the air-liquid interface to determine if an organic layer is present and if present the depth of the layer. Refer to Procedure SC-(0)7 for detailed sampling instructions. Operation of the bottom opening sampler is described in Procedure SC-()()3.

a. Raise the soft sludge sampler to the surface. Inspect the sample visually for the presence of immiscible liquid phases. If an immiscible (i.e. organic) layer is observed on top of the aqueous supernate estimate the thickness of the organic layer in the sample collection tube and record on the data collection form.

b. If an organic layer is present, remove the soft-sludge sampler tube from the handle and follow instructions in step 8.

8. If detectable organics are present, the two-phase sample in the soft sludge sampler tube will be packaged and a larger sample of the organic layer will be taken according to Procedure SC-(0)7.

a. Remove the handle from the soft sludge sampler containing the liquid layers. Cap and wipe the sampler tube.

b. Place the sample tube into the prelabeled plastic bag and tape the bag closed. Place the wrapped sample into a second plastic bag. Close the bag, place it in to the prelabeled can, and then place the packaged sample into the shielded transport carrier. This sample will be taken to the High Radiation Level Andiyicai Laboratory (Building 2(126) in order to measure the exaci height of the organic layer. The packing should keep the sample tube approximately vertical. Record the requested sample data on page 2 of the data collection form (Fig. 1-3). Complete the chain of custody form for the sample. 


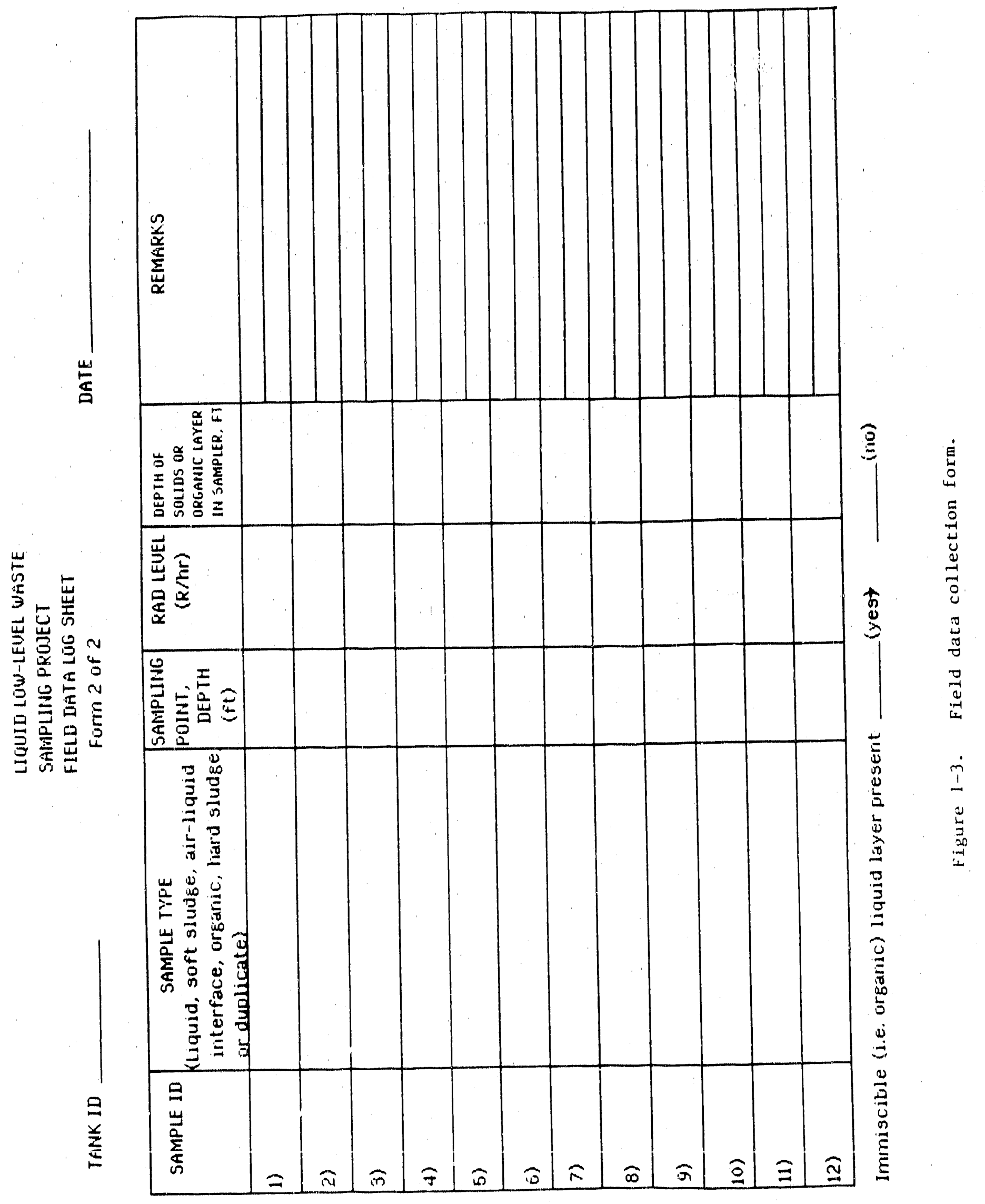


c. Collect a larger sample of the organic layer following Procedure SC-()()7. Cap and wipe the organic sampler tube, and place it in the prelabeled plastic bag. Place it into a second plastic bag, and then into a labeled can. Place the packaged sample into the shielded transport carrier. The packing should keep the sample tube upright. Record the requested sample data on page 2 of the data collection form (Figure 1-3). Complete the chain of custody form for the sample.

d. If the height of the organic layer is less than one-third the height of the organic sampler, take d second sample repeating step $8 c$.

9. If detectable organics are not found, return the liquid sample to the tank, and proceed with the sludge sampling procedure, step 11.

1). This alternate procedure is followed if a thick organic layer ( $>10$ ) inches thick) is detected with the Markland detector during the presampling survey. Determine the thickness of the organic layer from the Markland detector. Take one $250 \mathrm{~mL}$ sample at the one-half level (i. e. midpoint) of the organic layer with the vacuum pump liquid sampling system. Refer to Procedure SC-()()2 for sampler operating instructions, and step 6 of this procedure for handling and preparing the sample for transport.

11. Sample sludge in the tank using the soft sludge sampler as described in Procedure SC-()(3, Soft Sludge Sampling Procedure. The sludge sampler is capable of taking a 15 -inch long core sample. If the sludge depth is suspected to be more than 15 inches, or if the sampler has been lowered 15 inches from the top of the sludge without reaching the bottom of the tank, do not attempt to collect more than a 15inch core with the first sample.

a. Monitor radiation levels continuously as the sampler is removed from the tank, and wipe down the sampler handle and cap the tube.

b. Visually inspect the sample, and estimate the sludge depth in the sample tube.

c. Place the sample tube into the prelabeled plastic bag. Tape the bag closed. Place the wrapped sample into another plastic hag. Close the bag, place it in a labeled can and then into the shielded transport carrier. The packing should keep the sample tube approximately vertical.

d. Record the requested sample data on page 2 of the data collection form. Complete the chain-of-custody form for the sample.

If the sludge depth is greater than 15 inches, or the sampler did not reach the bottom of the tank, take a second sample below the first sample to obtain a full vertical core of the sludge in the tank. Close the sampler until the bottom tip of the sampler is approximately 1 inch above the lowest point previously sampled. Then open the sampler, lower the sampler, and collect the sludge sample. Remove and package the sample as above. Continue collecting samples at successively lower depths until a hard surface is encountered. Record the depth to the level resistance was encountered. 
12. If hard sludge is encountered which cannot be collected with the soft-sludge sampler, use the sampler described in Procedure SC-()()4, Hard Sludge Sampling Procedure.

After the hard sludge sample as been taken, prepare the sample:

a. Place the sampler into a labeled PVC container. Seal the PVC container with the cap. Place the PVC container ir a plastic bag, place it into a labeled can, and place the can in the shielded transport carrier.

b. Record the radiation level of the sample.

c. Complete the chain-of-custudy form for the sample. Record the sample data on page 2 of the data collection form.

13. Close the tank access. Have I\&C personnel reconnect the liquid level instrumentation. Verify that the liquid level instrumentation is working properly.

14. Decontaminate the sampling equipment per the instructions in Procedure SC-(0)5. Tag with the HP tag.

15. Package the waste, tag it with the HP tag, and dispose of the waste per the Waste Management Plan.

16. Deliver the samples, with the HP tags, the chain-of-custody forms (Procedure SC006, Sampling Custody) and the Request for Analytical Services form to the sample custodian or designated alternate authorized to receive samples for Inorganic and Physical Analysis, at the High Radiation Level Analytical Laboratory (Bldg.2026). All samples collected should be delivered the same day before 3:00 p.m. 


\section{Procedure SC-002 Vacuum Pump Liquid Sampling Procedure}

A vacuum pump sampling system will be used to take liquid samples from the waste tanks. A schematic of the system is shown in Fig. 2-1. The samples will be punyped through Teflon tubing directly into the sample bottles. Precleaned glass bottles with Teflon-lined lids will be provided for liquid samples when required for the planned analyses. The pump is arranged with a safety surge bottle as a backup if an overflow should occur, thus minimizing the potential for contamination of the pump. Both bottles should be placed inside a pan for containment in the event that a spill or leak should occur. The sampling bottle system has blotter paper underneath it so that any spills can be contained, collected, and disposed of properly. A small cartridge type HEPA filter will be installed on the vacuum pump air discharge. This is a precautionary measure. No airborne radioactive emissions were detected by the air monitor in previous sampling of these tanks when no filter was used. The waste solutons are viscous and the sample must be lifted by suction a height of $12 \mathrm{ft}$ or more. In the event that the filter causes problems, the filter will not be used.

\section{Presimpling Procedure}

1. A presampling survey will be conducted (see Procedure SC-(K)1). This should be done at least one day in advance to allow time for the disturbed solids to settle. At this time the air-liquid and the licjuid-sludge interfaces will be located, thus establishing the depth of the supernatant licyuid..

2. After the liquid depth had been determined, cut Teflon tubing to the lengths specified by $1 / 3,1 / 2$, and $2 / 3$ of the supernatant depth plus the distance from the top of the supernatant liquid to the sample bottle. Premark the tubes with tape to indicate when the appropriate level has been reached in the tank. Attach a stainless steel weight to the zero end of the tubing and a cap on the sample bottle end. New tubing will be used at each sample location to avoid cross-contamination of the samples. Label the sample bottle before collecting the siample.

\section{Sample Collection}

3. Slowly lower the Teflon tubing into the tank to the specified sampling level. The top end of the tubing is plugged to restrict entry of tank liquid into the tubing while it is lowered to the specified sampling level. The stainless steel weight attached to the lower end of the tubing will keep the tubing vertical during sampling.

4. When the ubhing has reached the specified depth, remove the cap from the top of the tubing, attach the sample bottle, and turn on the vacuum pump. When the $250-\mathrm{mL}$ sample bottle is nearly full turn the pump off and release the vacuum remaining in the system. Disconnect and cap the sample bottle. If duplicate samples are requested, replace it with an empty bottle and collect another liquid sample.

5. After the required sample(s) has been taken, allow any remaining liquid in the tubing to drain back into the tank. The tubing and weight assembly is removed from the tank and placed in a plastic bag along with absorbent paper to absorb any residual free liquid. The bag is sealed for disposal per the Waste Management Plan. 
E-18

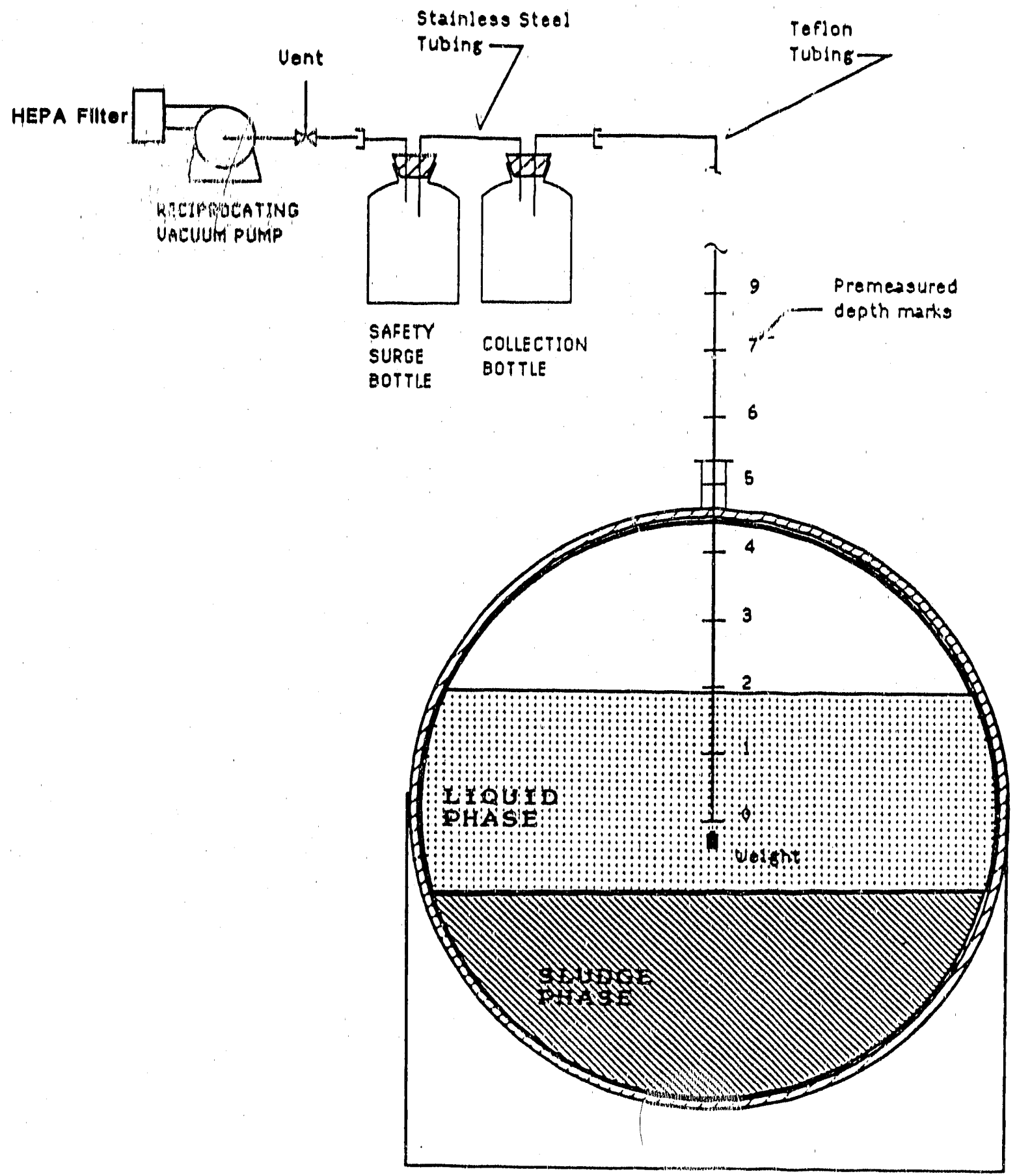

Figure 2-1. Liquid sampling system. 


\section{Procedure SC-(0)3 Soft Sludge Sampling Procedure:}

The soft-sludge sampler developed for the inactive tanks sampling campaign with minor modifications will be used to sample soft tank sludge (see Fig, 3-1). (This bottom opening sampler will also be used to collect a column of liquid to check for immiscible layers or if stratified layers are suspected.). The handle for these samplers can be broken down into 5-foot sections by removing the lock pins. Operation of these samplers is described below. Label the plastic bags and the can which will be used to package the sample in advance of collecting the sample.

1. Assemble the sampler sections and check that the sampler alignment is correct and the sampler operates properly. With the handle in position A (Fig. 3-1), seal the sample collection tube by depressing the handle completely until it contacts the locking hole ling.

Note: Never move the handle from position A without depressing the handle or damage to the gasket at the bottom of the sample collection tube could occur.

'Turn the handle to position $B$, and raise the handle until hole $A$ aligns with the locking hole. Check that the small pipe plug is removed from the side of the PVC sample collection tube.

2. Insert the sampler into the tank until the tip of the sample collection tube is approximately 12 inches below the liquid surface as was measured with the Markland Sludge Level Detector. If the depth of the liquid in the tank is less than 12 inches, lower the sampler until the tip of rhe sample collection tube is just below the liquid surface.

Note: If evidence exists of an organic layer on top of the liquid layer, do not open the sampler until well below the organic layer.

3. Open the sample collection tube by depressing the handle completely. Then turn the handle back to position $A$. Raise the handle until hole $A$ aligns with the locking hole.

4. Take the sludge sample by slowly lowering the sampler to the bottom of the tank. If the sludge of the tank is known or suspected to be more than 15 in deep, follow instructions in Procedure SC-()()1, Step 11 for collecting more than one sample to obtain a full core of sludge.

5. After the sample has been taken, the sample collection tube must be resealed. Depress the handle until it contacts the locking lug. 'To do this, the sampler assembly must be raised slightly off the tank bottom, approximately $1 / 4$ to $1 / 8$ inch. With the handle completely depressed, turn it to position B. Raise the handle until hole $B$ aligns with the locking hole and reinsert the locking pin.

6. Carefully remove the sampler from the tank, maintaining the sampler in the vertical position. Wipe down the outside of the sampler as it is removed from the tank. Place wipes in a plastic bag.

7. Unscrew the sample collection tube from the handle, and replace the small pipe plug in the side of the sampling tube. Place a 1 -in NPT pipe cap which has been prelabeled on the top of the sample collection tube. 


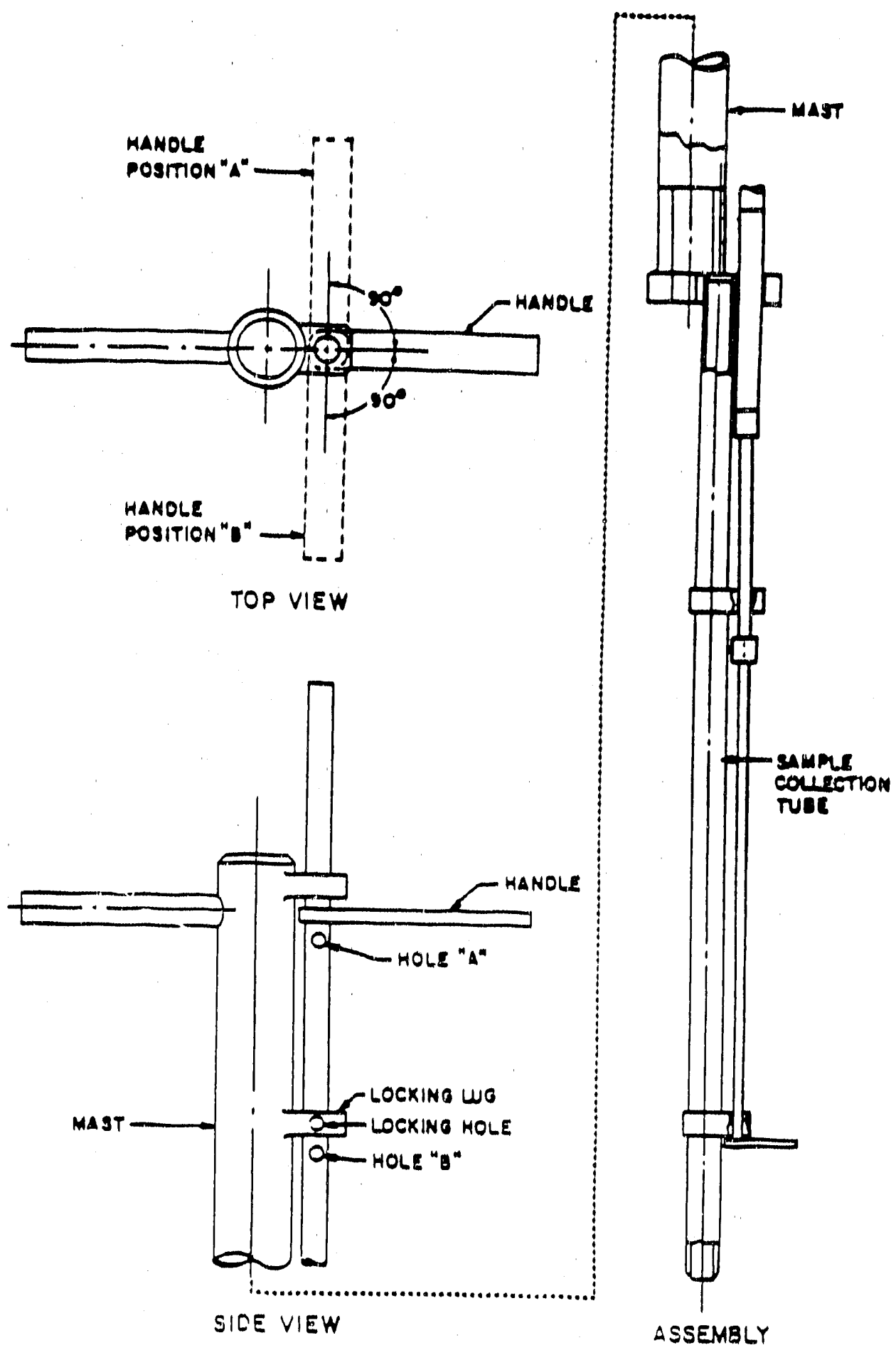

Figure 3-1. Soft sludge equipment. 
Rev. 1

8. Place the sample collection tube in the prelabeled plastic bag and tape the bag closed. Place the wrapped sample tube in a second bag, close the bag, and then put the wrapped sample in the prelabeled can. Place the packaged sample into the shielded transport carrier.

9. Take a second sample if required:

a. If the sludge depth is suspected to be more than 15 inches or if the sampler did not reach bottom take a sample from the lower part of the same hole. Close the sampler until the bottom tip of the sampler is approximately 1 inch above the lowest point previously sampled. Then open the sampler, $k$ the sampler, and collect the sludge sample. Remove and package the sim, is above. Continue collecting samples at successively lower depths until a hard surface is encountered. Record the depth to the level resistance was encountered.

b. If the solids fill less than $2 / 3$ of the sampler used for the bottom of the tank take a second sample from a different hole as much as possible to obtain a larger quantity of solids.

10. After the sample has been taken, the handle rnust be decontaminated as described in Procedure SC-()(5), Decontamination of Sampling Equipment. 


\section{Procedure SC-004 Lard Sludge Sampling Procedure}

\section{Commercial Hurd Sludge Sumpler}

A commercial hard sludge sumpler with a sharper tip will be available for use if the consoliduted sumple cannot be obtained with the soft sludge sampler. This sampler consists of a stainless steel pipe (barrel) with a liner, sharpened blades at the bottom, a gate valve to hold the sample in, a vented cap, and handle sectlons. A schematic of the apparatus is shown in Fig, 4-1. The sampler can be assembled with either an auger type bit for hard sludges (Fig. 4-1) or a push type cutting end for sticky, "mud" consistency sludges. The bit has been designed to cut the hard sludge with little disturbance of the rest of the material. A cross handle will be used to apply turning pressure on the sumpler to cut the sludge.

1. Assemble the sampler sections and handle. Label the PVC container, plastic bag, and and can which will be used to package the sample. Place the PVC contalner near the sampling port.

2. Lower the sampler into the lank. When the sampler reaches the hard sludge, turn the cross handle to cut the sludge. Use only manual pressure and do not force.

3. After the hard sludge has been cut, remove the sampler from the tank. Wipe down the handle and outside of the sampler as the assembly is removed from the tank, Do not wipe the cutting blades. Remove the handle and place the sampler into the PVC container. Seal the PVC container with the cap. Wrap the PVC container in the plastic bag and place it into the can. Place the packaged sample into the shielded transport carrier. Place the wipes in a plastic bag.

4. After the sample has been laken, the handle must be decontaminated as described in Procedure SC-(O) ()5, Decontamination of Sampling Equipment.

\section{Allermile Hard Sludge Sampler}

The hard sludge sampler developed for the inactive lanks simpling project will be available as a backup to the commercial simpler. This device consists of a stainless steel pipe which has a sharp, machine-bevel cutling edge on one end, and is threaded at the other end so that it can be altached to a handle. This simpler is suitable only for very thick, sticky sludges. The cores are stored in a specially designed stainless steel sample containers.

1. Assemble the mast (handle) sections and attach to the sampler. Label the stainless steel container and a "paint" call.

2. Lower the sampler into the lank. Force the sumpler into the sludge by pushing down or twisting the handle. Do not use any impact force or allow more than one person at a time 10 push on the simpler.

3. Position the sample container near the tank port.

4. Remove the sampler assembly from the tank, wiping down the mast sections and removing all but the last mist section as they clear the lank. Place the wipes in a plastic bag. 
1024

ORNL DWG 89-281

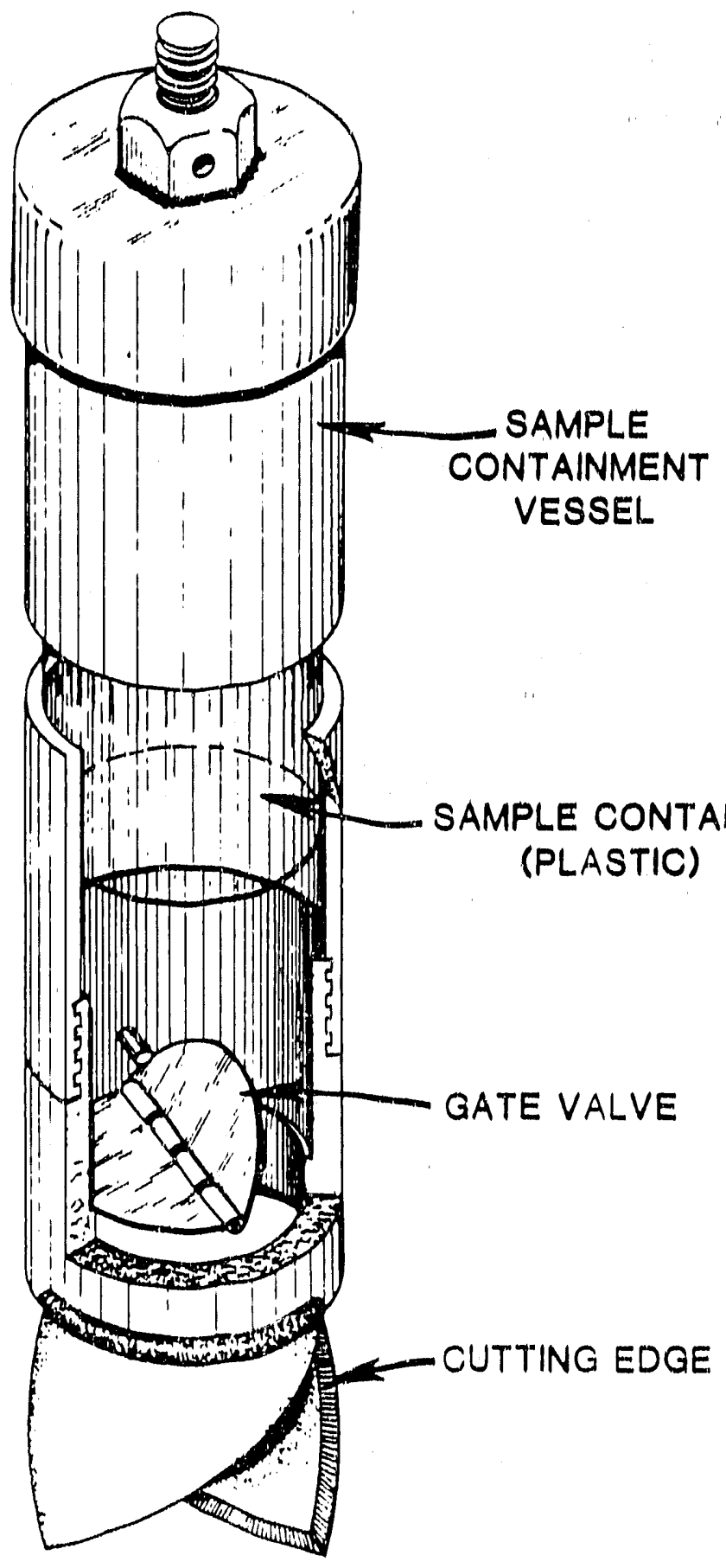

Figure 4-1. Scheme of the hard sludge sampler. 
5. Lift the final mast sectlon and hard sludge sumpling devlec from the tank, and insert the sampler Into the sample container. Unscrew the mast sectlon from the sumpler. Seal the sumple container using the cap. Wipe any residues from the outside surfice of the contalner, wrap it in a plastic bag, and place it into a "palnt" can. Place the packaged sumple in the stainless steel transport carrier.

6. Decontaminate the handle as described in Procedure SC. ()().5. Decomiamination of Sampling Equipment. 


\section{Procedure SC-005 Decontamination of Sampling Lédulpment Procedure}

This procedure describes methods to decontaminate sumpling equipment before and after use to prevent contamination of the samples and to reduce radialon exposure io personnel from contuminated sampling equipment. All sludge simpling equipment must be: decontaminated prior to the first use to remove shop ofls or soll to avold contamination of the sample. The 1-Chem glass sumple bottles have been purchased preceleanced and should not be opened until just before the sumple is collected. The licyuld sumpling eyulpment such as the stainless steel tublng should be rinsed with deionlzed water and methanol prior to use and allowed to dry. It may not be prastical to preclean some equi, nent, such as the feflon lubing before use.

Cleaning of the PVC sludge sumple collectors, the plastic containers for the sludge simplers and the "Mason" furs used with the pump module simpler prior to use: Wash whth tap water and "Micro" detergent (cun be obtained from Analytical Chemistry Division), rinse with tap waler, and then rinse well with deionized water. Allow to dry in a clean area. Alter drying place equipment in a plastic bag or wrap in plastic lo keep equipment clean until use. Leave the bottom of the sludge sampler open so the probe dexes not indent the gasket.

Hard sludge samplers (except for the handles) should be cleaned in a similar manner to the PV'C sludge sample containers prior to use.

Organic layer sumplers should be cleaned in a similar manner to the PVC sludge sample containers prior to use.

Cleaning of sludge sampler handles; Prior to first use clean the outside of the sampler handles will spray cleaner and rags. Between tanks wipe down the outside of the sampler handles with a spray cleaner and rags to remove the residues as the handle is withdriawn from the tank. Place the wipes in a plastic bag. Then wipe down the entire handle exterior with spray cleaner. If sludge has gotten into the handle interior, try to wipe it out. Have the HP check the handle, if the handle cannot be cleaned in the ficld to levels approved by the HP, wrap the handle in plastic, have it tagged by the HP, and transport it to Building 3074 for decontamination.

Sludge level detector: Wipe down the detector head and cable with spraly cleaner and rags alter use in each tank. Visible contamination and oils should be removed. Ilave it checked by the HP.

Any contaminated equipment which is to be transported within the plant area or stored must be tagged by the IIP as a radionctively contaminated item. 


\section{Procedure Sca(0)o Sumpling Custody}

A simple is considered to be under a persom's custody fl it is (1) In a person's physical posisession, (2) In vlew of the persen iffer laking posisession, (3) secured by that person so

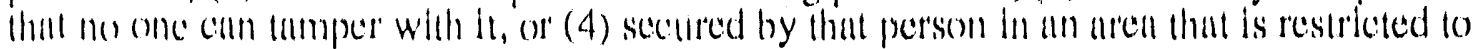
minhorized personncl.

1. Somple Labeds- Simple labels are necessing to prevent the misidentificution of

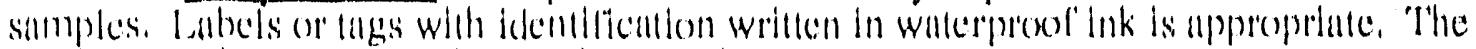
label should include the following information:

- Sample number

- Dille and lime of collection

- Iaciation of collection point

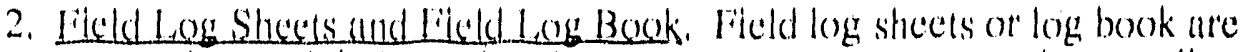

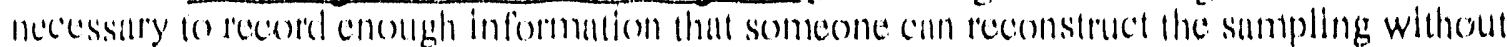
reliance on the collector's memory. 'I'he log sheets or log book should contaln the following information for completeness of the sumpling siluation:

project minne

Purpose of simpling

Sumple number

- Lacition of sampling point

- I'ype of' simple (sludge, walcer, etc.)

- Q (uantily of simple laken

- Description of sampling point and sampling methoxlology

- Dalte and time ol collection

- Namm:(s) of collector(s)

- Signalure(s) of person(s) responsible for sumpling or obscrvaltions written in the log shects/hork.

Liximples of the fïcld log shects are provided in liggs, 6-1 and 6-2.

3. Chain-of-Custexly. The chain-of-custody form should aceompany the sample to

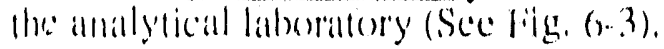

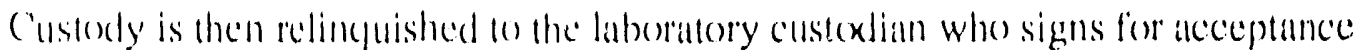
of the simple(s). When the sample is relinguished, than person should sign the chain-ofcuslexly form and indicate the date and lime custody was relinguished. The person ecesiving custorly of the simple should provide al signature, date, time, department, building, and phone: mumber on the chain-of -custexly form. This procedure should be

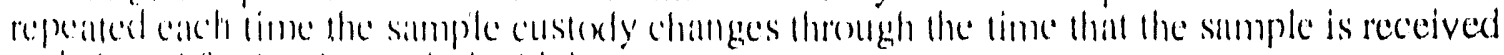

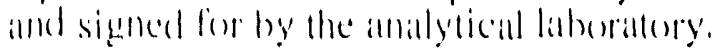

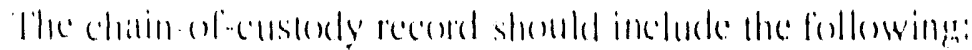

Simple mumber

Signillures(s) of collecomes

Dite and time of conllection

Plice and lexition of collecilinn

Sillmple lype

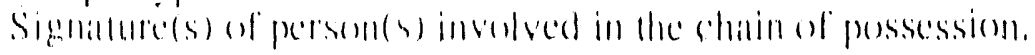

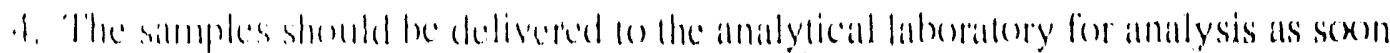

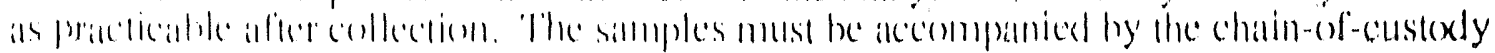


E-30

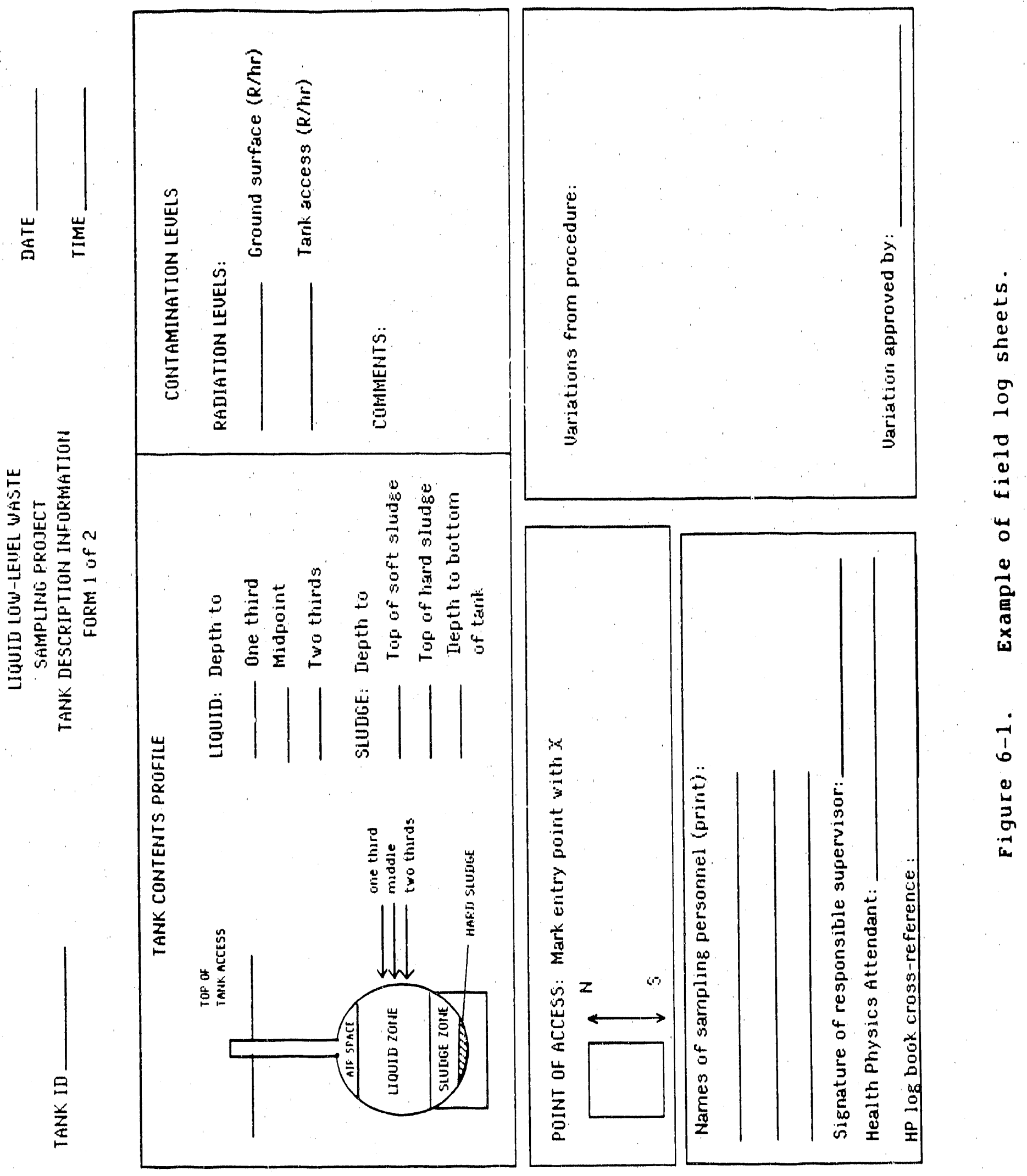




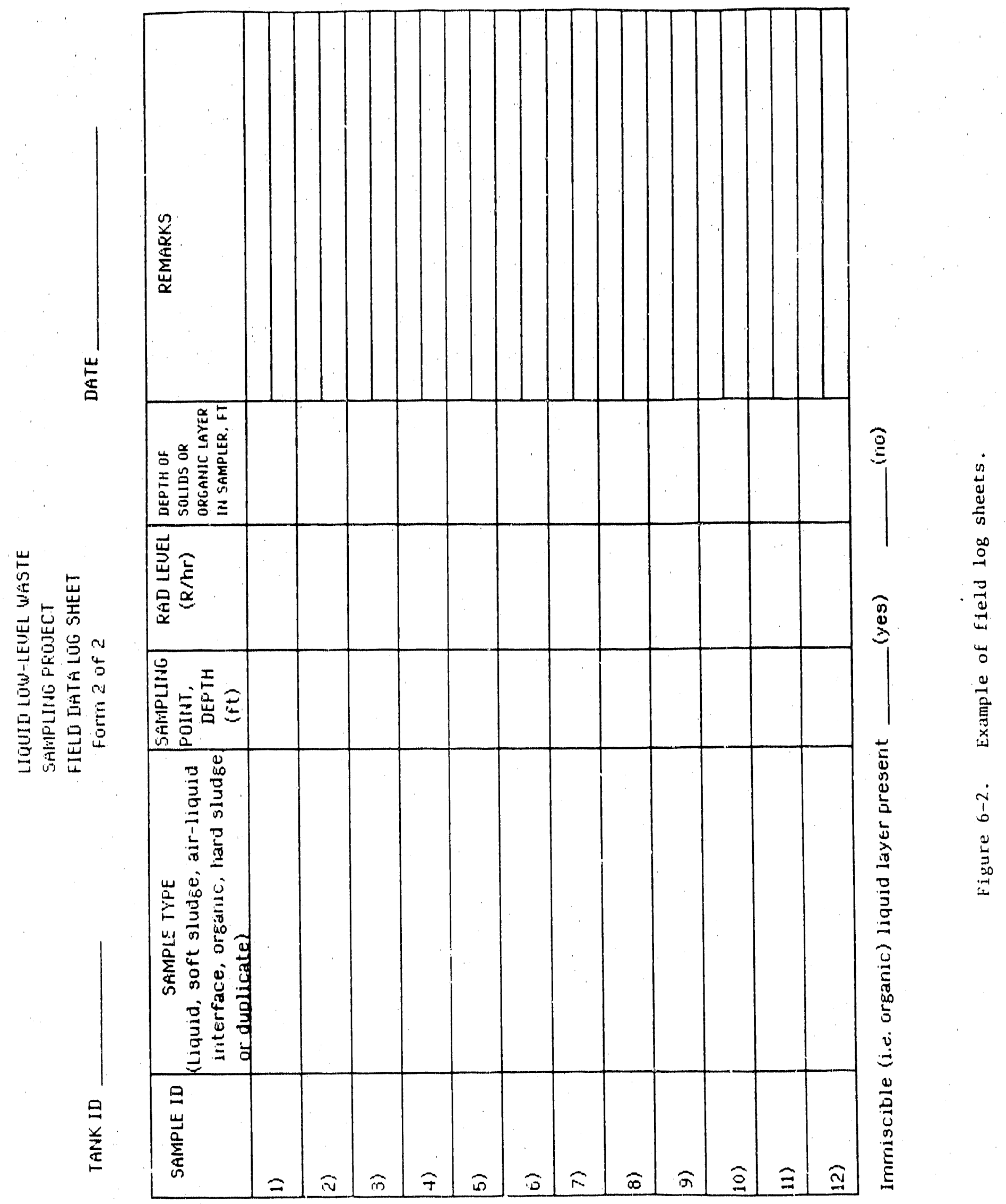




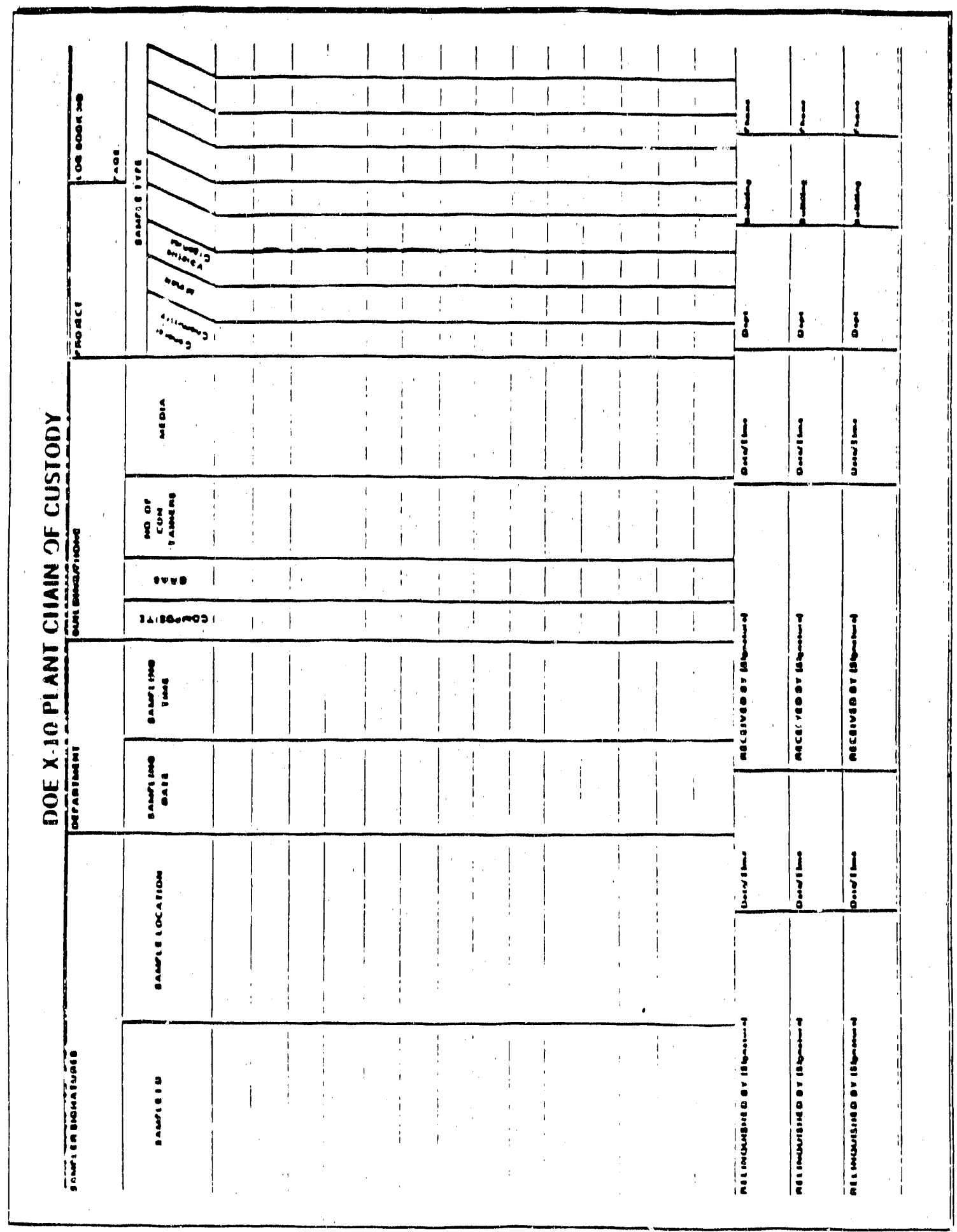

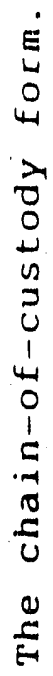

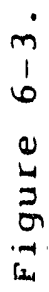


Rev. 1

record. The samples mut be delivered to the person in the laboratory authorized to receive the samples. Custody must be relinquished to the custodian who must sign for acceptance of the samples. Once the sample has been accepted at the laboratory, standard laboratory chain-of-custody procedures will be followed. The completed chain-of-custody forms should be returned to the Task Leader with a xerox copy to J.J. Ferrada.

5. Archive samples should be delivered to the storage area. Initially the northeast cell of the east cell bank in Bldg. 3503 will be used to store samples. The long-term archive plan is to use the east pipe tunnel of Bldg. 3019 for storing samples. The samples must be delivered to the person in the Engineering Development Section of the Chemical Technology Division authorized to receive the samples. J. B. Berry (or designated alternate) should be notified in advance that samples are ready to be archived. Custody must be relinquished to the custodian who must sign for acceptance of the samples. Once the sample has been accepted at the archive, the sample custodian for the Engineering Development Section will maintain the chain-of-custody. The completed chain-of-custody forms should be returned to the Task Leader with a xerox copy to J. J. Ferrada. 


\section{Procedure SC-007 Organic Laver Sampling Procedure}

The organic layer sampling is in two parts: (1) to determine if an organic layer is present and if so the depth of the layer, and (2) if an organic layer is detected a larger sample of the organic phase is collected using a specially designed organic layer sampler. Information about the location of the air-liquid interface will be available from the presampling survey. If an organic layer which is several inches thick is present, information about the organic-aqueous interface may be available from the presampling survey.

1. Take a vertical "core" of liquid at the air-liquid interface using the bottom opening soft sludge sampler to check for the possible presence of an organic layer above the aqueous layer and to estimate the depth of the organic phase. Refer to Procedure SC-(0)3 for ditails of the mechanical operation of the sampler. Submerge the soft sludge sampler, opened at the bottom, until the bottom is approximately 8 inches below the liquid surface. If an organic layer more than 4 inches thick is suspected, submerge the sampler until the bottom is approximately 5 inches below the organic-aqueous interface and not more than about 15 inches below the air-liquid interface. Seal the bottom of the sampling tube. Raise the soft sludge sampler to the surface. Visually inspect the sample for the presence of immiscible phases. If an immiscible (i.e. organic) layer is observed on top the aqueous phase proceed with step 2 of this procedure. If no immiscible phase is present return the sampler to the tank at the same point where it was pulled, release the liquid, and proceed with sampling the sludge as described in Procedure SC-1 ()1, step 11, and Procedure SC-()()3.

2. If an organic phase is prest nt wipe the outside of the soft sludge sampler tube, put the Allen screw back in position, remove the handle, and cap the top of the sampler tube.

3. Place the sampler tube in the prelabeled plastic bag and tape the bag closed. Insert the wrapped sample tube into the second plastic bang and tape the outer bag closed. Then place it into the prelabeled can, and put it into the shielded transport carrier.

4. Collect a second (larger) sample of the organic phase using the special organic sampler. This is a PVC ube with a sealed bottom and a lateral tube for liquid intake near the top (see Fig. 7-1). The handle of the sampler is the same as is used with the soft sludge sampler. Premeasure and mark the handle with tape the appropriate distance for the lateral tube to reach the liquid organic surface. Remove the caps from the lateral tube and the Allen screw from the side. Label the plastic bags and the can which will be used to package the sample.

5. Lower the sampler until the lateral tube reaches the liquid surface. Hold the sampler in that position for 3() seconds to assure that the sampler has filled with liquid.

6. After the time has elapsed, carefully remove the sampler from the tank, maintaining the sampler in the vertical position. Cap the lateral tube with a 1 inch NPT pipe calp and wipe the sampler down as it is removed from the tank. 


\section{E-36}

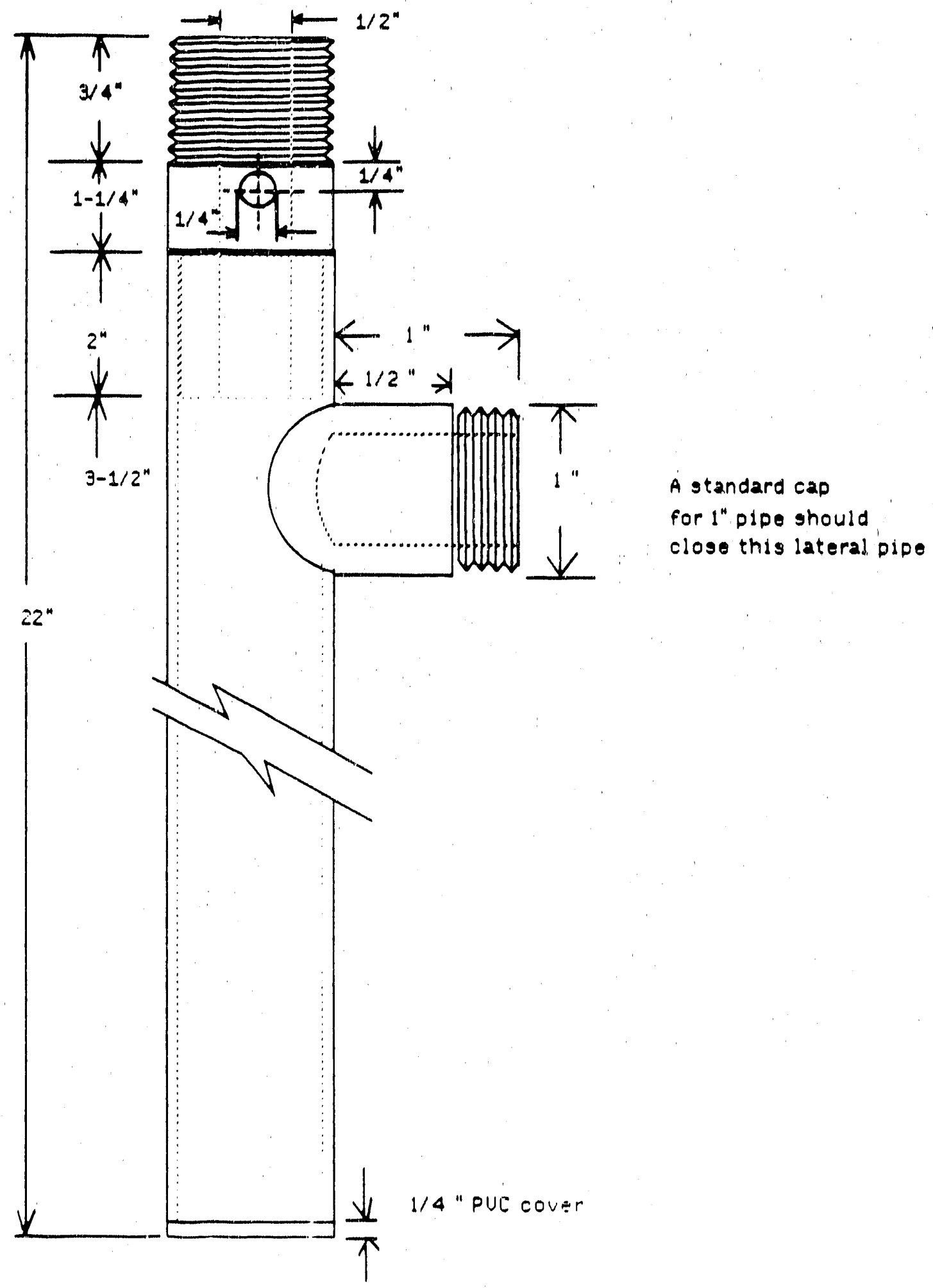

Figure 7-1. organic layer sampler. 
Rev. 1

7. Unscrew the sample collection tube from the handle. Place a 1 -inch NPT pipe cap on the top of the collection tube, and replace the Allen screw in the side of the collection tube.

8. Place the sample collection tube in the prelabeled plastic bag and tape the bag closed. Insert the wrapped sample tube into the second plastic bag and tape the outer bag closed. Then place it into the labeled can, and put it into the shielded transport carrier.

9. If the height of the organic phase is less than one third of the length of the organic sampler tube, take a second sample.

10. Decontaminate the handle as described in Procedure SC-005, Decontamination of Sampling Equipment. 


\section{Procedure SC-008 Archive for Liquid Low-Level Waste Samples}

After the planned analyses have been completed, the residual sample may be stored for use later in experiments to develop methods for processing the wastes for disposal. Duplicate samples from the field or portions of samples which have been divided at the analytical laboratory may also be archived so that additional analyses can be performed if needed.

The northeast cell of the east cell bank in Bldg. 3503 will be used to store samples initially. The long-term archive plan is the use the east pipe tunnel of Bldg. 3019 as the storage area. This area is being prepared for use. When the east pipe tunnel of Bldg. 3()19 is ready for sample storage, all samples will be transferred from Bldg. 3503, and Bldg. 3503 will no longer be used for sample storage.

The samples will be in glass jars, which are placed in plastic bags and the bags sealed with tape. The jar will be labeled with the sample number, the identification code of the tank sampled, and the date collected. Each sample will then be placed in a lead pig, which should be marked with the sample number and date collected on the outside of the pig. The HP tag should be attached to the lead pig. Each pig should be sealed with a custody seal which must be broken to open the pig. The lid of the lead pig should have a wire handle.

The archive custodian (J. B. Berry or designated alternate) for the Engineering Development Section of the Chemical Technology Division is responsible for the sample archive. The custodian should be notified in advance when samples are ready to be archived.

An inventory of stored samples will be maintained and posted outside the storage area. An inspection of the storage area will be conducted at least once a year. A new chain-ofcustody seal should be used with the initials of the inspector and the date of inspection marked on the seal if a lead pig is opened.

Health Physics personnel will monitor the transfer of samples and Health Physics procedures for radiation protection will be followed. 


\section{APPENDIX F}

PROCEDURE FOR SAMPLING TANKS W-29 AND W-30

USING THE PUMP MODULE (ISOLOCK) SAMPLER 
F-3

\section{INTRODUCTION}

The procedure for sampling tanks W-29 and W-30) using the pump module (Isolock) sampler follows in this appendix as the procedure was written. The sampler operated slower than expected which was probably because of corrosion. It was necessary to change some of the switch settings (0) increase the speed of the sampler. 


\section{SAMPLING FOR WASTE CHARACTERIZATION \\ PROCEDURE FOR SAMPLING TANKS W.29 AND W.30 \\ USING THE PUMP MODULE (ISOLOCK) SAMPLER}

Approved by:

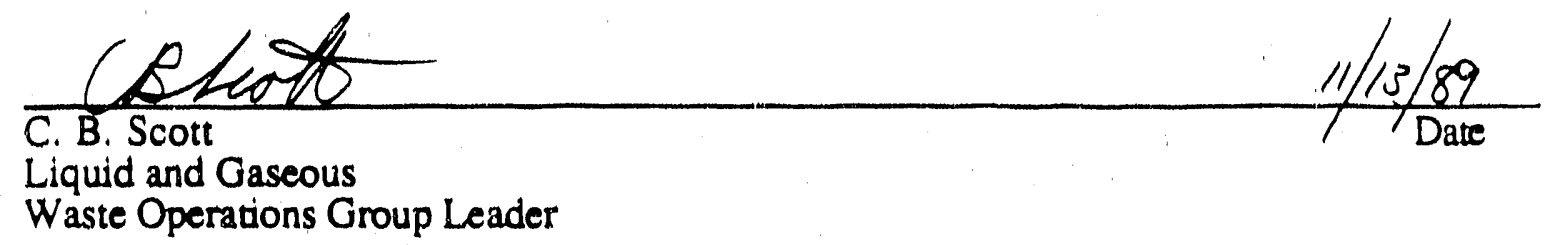

R. C. Tason, Task Leader

Waste Characterization

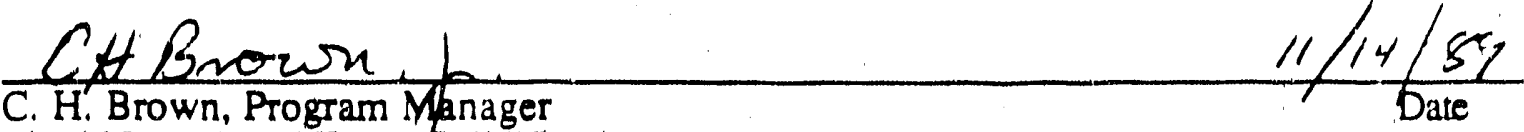
Liquid Low-Level WasteSolidification

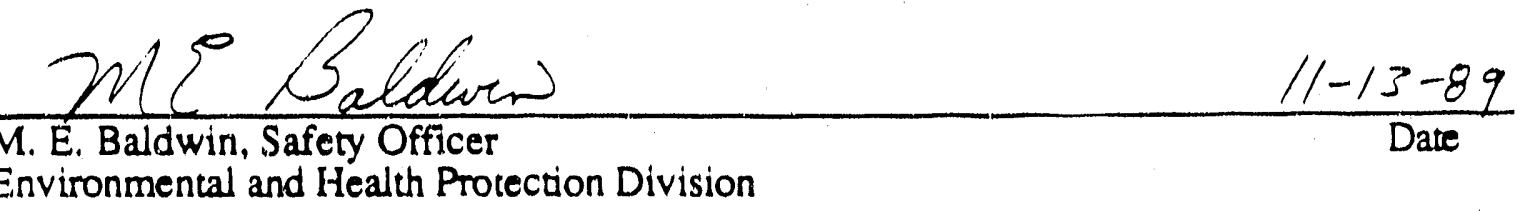




\section{Procedure SC-009 Procedure for Sampling Tanks W-22 and W-30 Using lihe Pump Module (lsolock) Samoler}

Tanks W-29 and W-30 were modified during the construction of the Emergency Avoidance Solidification Campaign (EASC) processing equipment. The penetrations used to house the mechanical level instrumentation were used for the pump module suction legs. Along with the suction legs, pneumatic tubing was put into the tank and tied into instrumentation used to give level readouts. Since it is not possible to gain access through these penetrations and sample the tanks as per Procedure SC....., General Sampling Procedure for Liquid Low-Level Waste Storage Tanks," the "Isolock" sampler housed in the EASC pump module will be used to pull the supernatant samples from W-29 and W-30). Sludge samples will not be pulled from these tanks. The sampling is to be conducted by operators familiar with the EASC processing equipment and certified on sume.

1. General Requirements and Presumpling

a. A Radiation Work Permit (RWP) is required for sampling any of the waste storage tanks. Sampling is to be conducted by trained chemical or erators in protective clothing as specified on the radiation work permit. Sampling activities shall be continuously monitored by radiation protection personnel. Air sampling is required. Electrical power (110 V) should be provided at the site to operate the radiation protection air sampler. There shall be no sampling operations if the temperature is below $35^{\circ} \mathrm{F}$ inside the building which houses the pump module.

Extremity dosimeters (finger rings) are required for all employees that directly handle the filled sample containers. All exposures of the employees involved in this task should be kept segregated from their overall exposures from day-to-day. activities (by use of recording pocket meter readings) so that the overall exposure information can be further utilized in future waste tank projects.

The sampling crew shall have training in handling low level, 'TRU, and mixed wastes, in the use of respirators, and in the project specific procedures.

b. Absorbent material shall be placed beneath the sampler in the sampler box to contain any drips or small spills. Try to avoid contaminating the drain in the sampler box. Do not install anything which might block or plug the drain. The drain must be open since it serves as both the ventilation vent for the sampler compartment and an emergency drain in case of a spill. Absorbent paper and plastic sheeting as appropriate shall be placed in the work area adjacent to the sampler compartment to confine the radioactive materials and prevent contact with the floor and other clean surfaces. Waste rags and materials used to wipe down equipment should be placed in a plastic bag. Spill containment ard clean-up materials shall be maintained and readily available within the work area.

c. The glass "Mason" jars used with the pump module sampler must be cleaned and allowed to dry prior to use per Procedure SC-()()5, "Decontamination of Sampling Equipment Procedure." The jars for the pamp module sampler are too large to put into a standard lead pig and do not have EPA approved caps. Therefore, immediately after the sample is collected it will be transferred to a $25($ ) - mL, widemouth I-Chem jar. This transfer is made inside the sampler compartment which is at a small negative pressure with respect to the atmosphere and has an emergency drain. Precleaned I-Chem jurs with Teflon-lined lids will be provided. 
d. Labels should be attached to the I-Chem sample jar and the lead pig before the sample is collected. Preprinted labels will be provided by J. J. Ferrada.

e. Care should be taken to keep the samples upright during handling and transport.

2. Preoperational Facilities Preparation

Note: Before the pump module is used, pertinent sections of Section 4, "Procedures for Preoperational Facilities Preparation," of WM-HRWO601 R1, Operating Procedures for the Emergency Avoidance Solidification Campaign, should be accomplished. These sections are as follows:
4.1 Start-up and Balancing of Solidification Building HVAC
4.2 Balancing of Pump Module Ventilation
4.3 Pressurization of Transfer Piping Annulus
4.4 Calibration of Tanks W-29 and W-30 Level Indicators
4.9 Preoperation:1 Checkout of Safety Systems

Also, it should be assured that a positive blockage (i.e., blind flange, pancake, etc.) exits in the system after HCV 100$) 2$ to assure no contaminated liquid exits P-1003-1"-146 into the solidification building.

After the pertinent parts of checksheet EASC-4.0 are filled out, the procedures below should be followed.

\section{Set Up Sampler as Follows}

In sampler control box, set up switch 1TR (cycle extend) switches so that 1 and 2 are "on." The rest of the switches $(4,8,16,32,64,128,256,512)$ should be in the "off" mode. This will give a cycle extend stroke time of 3 seconds. In the same box, set up switch 2TR (cycle retract) switches so that 1, 4, and 8 are "on" and the rest of the switches are "off." This setup will give a $25 \mathrm{~mL}$ sample every 15 seconds, or $100 \mathrm{~mL}$ per minute.

\section{Performing Necessary Valving at the Pump Module}

Note: It should be ascertained, from previous operational records, that all valves at the pump module are closed before these procedures are started. Source of prime water will also be tied into the quick disconnect connection at HV-38.

a. Open value HV-29 (W-29) or HV-30 (W-30), depending upon which tank is to be sampled. These are the suction valves for transfer pump J-()1.

b. Open HV-28, air supply to transfer pump.

c. Open HV-31 (W-30) or HV-32 (W-29), return line to the tank not being sampled. 
5. In Building 7877
a. Assure Programmable Logic Controller (PLC) is working properly
b. Assure all alarms are cleared
c. Push MMES "transfer ready" button
d. Short wires together to give vendor "transfer ready" indication
e. Switch pump controller to "local"

\section{6. $\quad$ At Pump Module}

a. Open the door of the sampler compartment. Have the HP check with a smoke tube that there is an inflow of air to the sampler compartment.

b. Attach a precleaned, 1-pint sample collection jar to sampler.

c. Start pump. Read the background on the piping to/from W-29 and W-30 to ascertain fluid transfer. If the pump has not picked up, prime it by opening valves HV-38 and HV-36. After priming close valves HV-36 and HV-38.

d. After it is ascertained that fluid is being circulated, wait 2 minutes and switch the sampler control switch to "auto." Wait until the proper amount of sample is collected $(100 \mathrm{~mL} / \mathrm{min}$ :ie). Turn the sampler to "off" position, and shut down pump J-(01. upen the sampler door. Carefully unscrew the sample collection jar from the sampler, and pour the sample into a prelabeled, 250-mL, wide-mouth I-Chem jar. Seal the I-Chem jar. Make this transfer inside the sampler compartment. Place wipes in a plastic bag. Use only lint-free wipes to wipe the nozzle of the sampler.

e. After a liquid sample has been taken, prepare the sample as follows:

Wipe off the exterior of the sample jar to remove any spilled liquid or possible contamination.

Place the jar in plastic bag(s) and close the bag with tape. Have the HP measure the radiation level of the unshielded sample. Place the wrapped sample in a lead pig. Label the container with information on the radiation level. The lid of the lead pig should have a wire handle.

Record sample data on page 2 of the field data collection form (see Attachment).

f. Collect three more samples by repeating the above process. Use a clean collection jar for each sample. 
g. After sampling the tank is complete, flush the module piping with water by doing the following:

Open HV-38

Open HV-36

Flush for 30 seconds

Close HV-36

Open HV-34

Flush for 30 seconds

Close HV-34

Close HV-38

Close HV-29 (HV-30)

Close HV-31 (HV-32)

h. Perform the necessary valving per step 4 to sample the other tank.

i. Before sampling the next tank, let the pump circulate waste for 1 hour 20 minutc's before activating the sampler.

j. Collect four samples from the second tank.

k. After the sampling of the second tank is complete, flush the module piping per step $6 \mathrm{~g}$.

When the module flush is completed after the second flush, open following valves on the module to drain it completely:

HV -29

HV -30

HV -31

HV -32

HV -33

$\mathrm{HV}-34$

HV -36

Let drain for 5 minutes.

1. Close all valves.

m. Disconnect the prime water source.

7. Waste Management

Package the waste, tag it with the HP tag, and dispose of the waste per the 'Naste Management Plan.

8. Sample Handling

a. Fill out documentation. See Attachment for the field log forms. Record on the field log sheet under comments that the pump module sampler was used. Complete the chain-of-custody form (Procedure SC-(0)6, "Sampling Custody").

b. Seal the lead pigs with tape for transport. 
c. Have the HP monitor the radiation level and tag with the "HP" tag (Radiation Hazard Materials Transfer Tag). If the radiation level at the surface of the pig is $100 \mathrm{mrem} / \mathrm{h}$ or less, the sample will be transported in the pig.

In the event that the radiation level at the outer surface of the pig should exceed $100 \mathrm{mrem} / \mathrm{h}$, place the pig in a paint can with crumpled plastic for padding and then into the stainless steel transport carrier.

d. Three samples from each tank -- the first, second, and fourth samples collected -- are to be analyzed. Deliver these samples, with the HP tags, the chain-of-custody forms (Procedure SC-006, "Sampling Custody") and the Request for Analytical Services form to the sample custodian or designated alternate authorized to receive samples for Inorganic and Physical Analysis, at the High Radiation L svel Analytical Laboratory (Bldg. 2026). All samples collected should be delivered the same day before 3:00 p.m.

e. One sample from each tank -- the third sample collected -- is to be archived. Attach a chain-of-custody seal over/across the tape which seals the pig. Either a preprinted label initialed and dated by the sample collector or a signed custody seal may be used. Deliver the archive samples, with the HP tags and the chain-of-custody form to J. B. Berry, or designated alternate, at Bldg. 3503. Contact J. B. Berry or designated alternate in advance so that arrangements can be made.

9. Post-operational Steps

a. Rernove the jumpered condition applied in Step 5d.

b. Verify equipment is returned to shutdown status, 


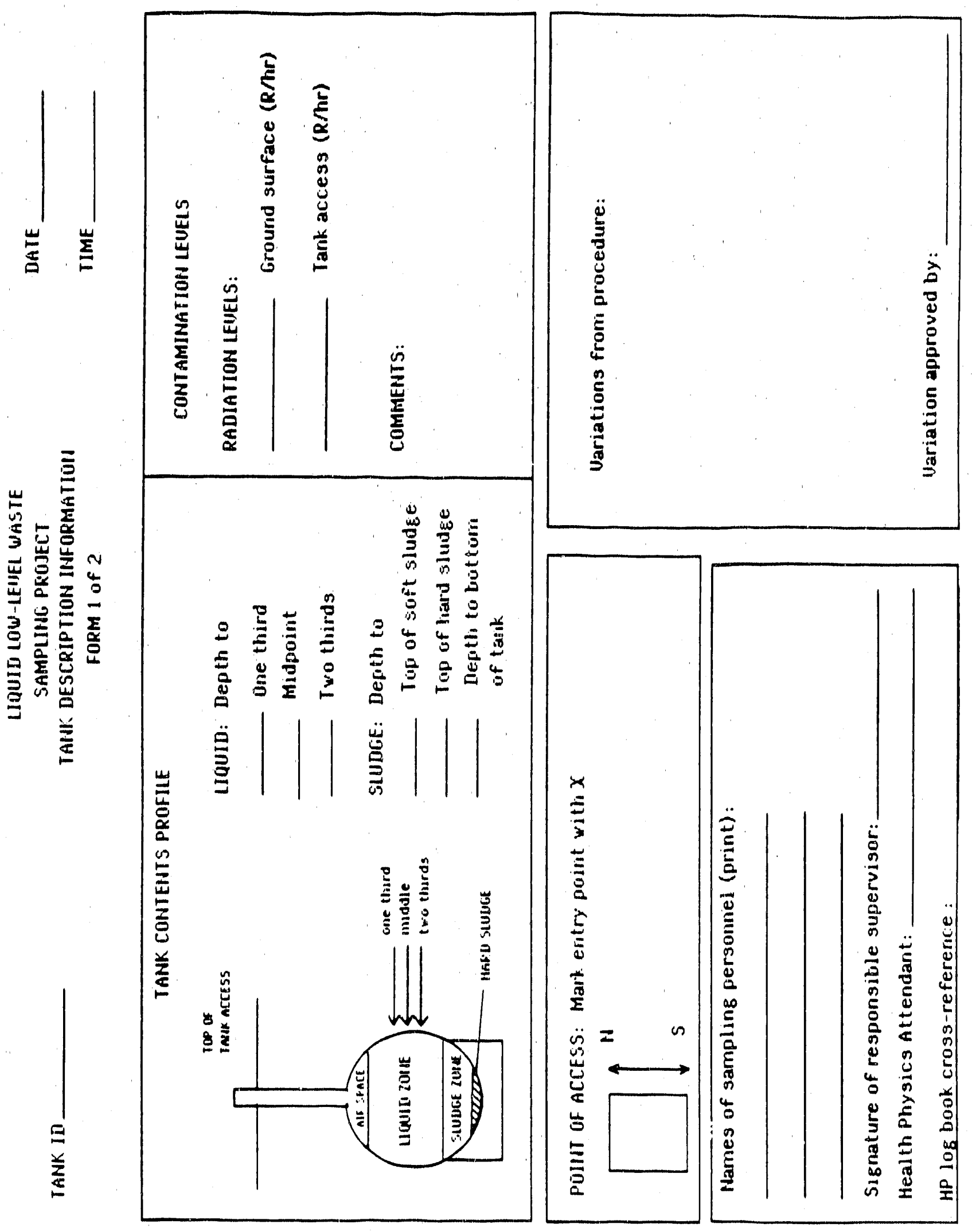




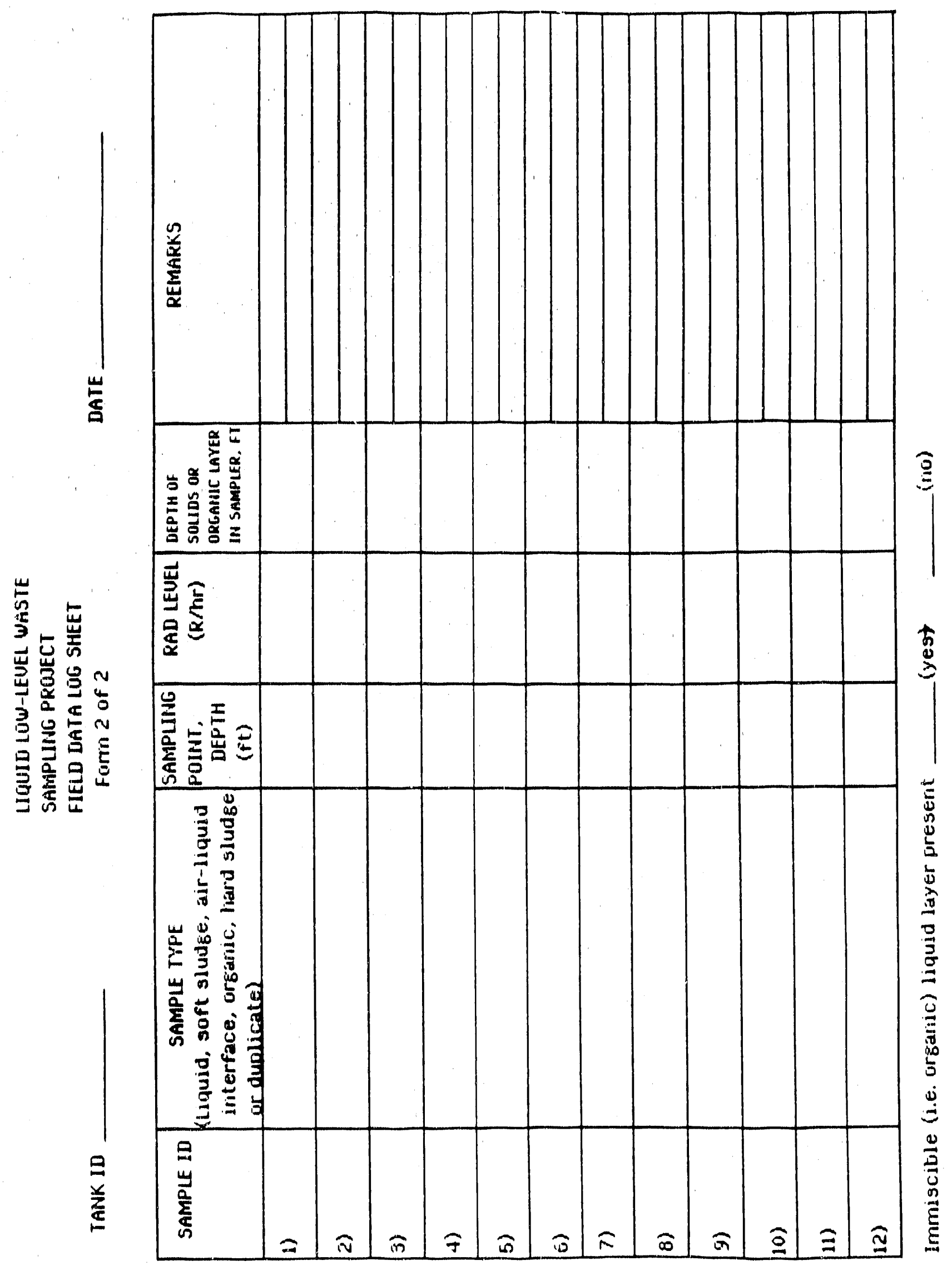



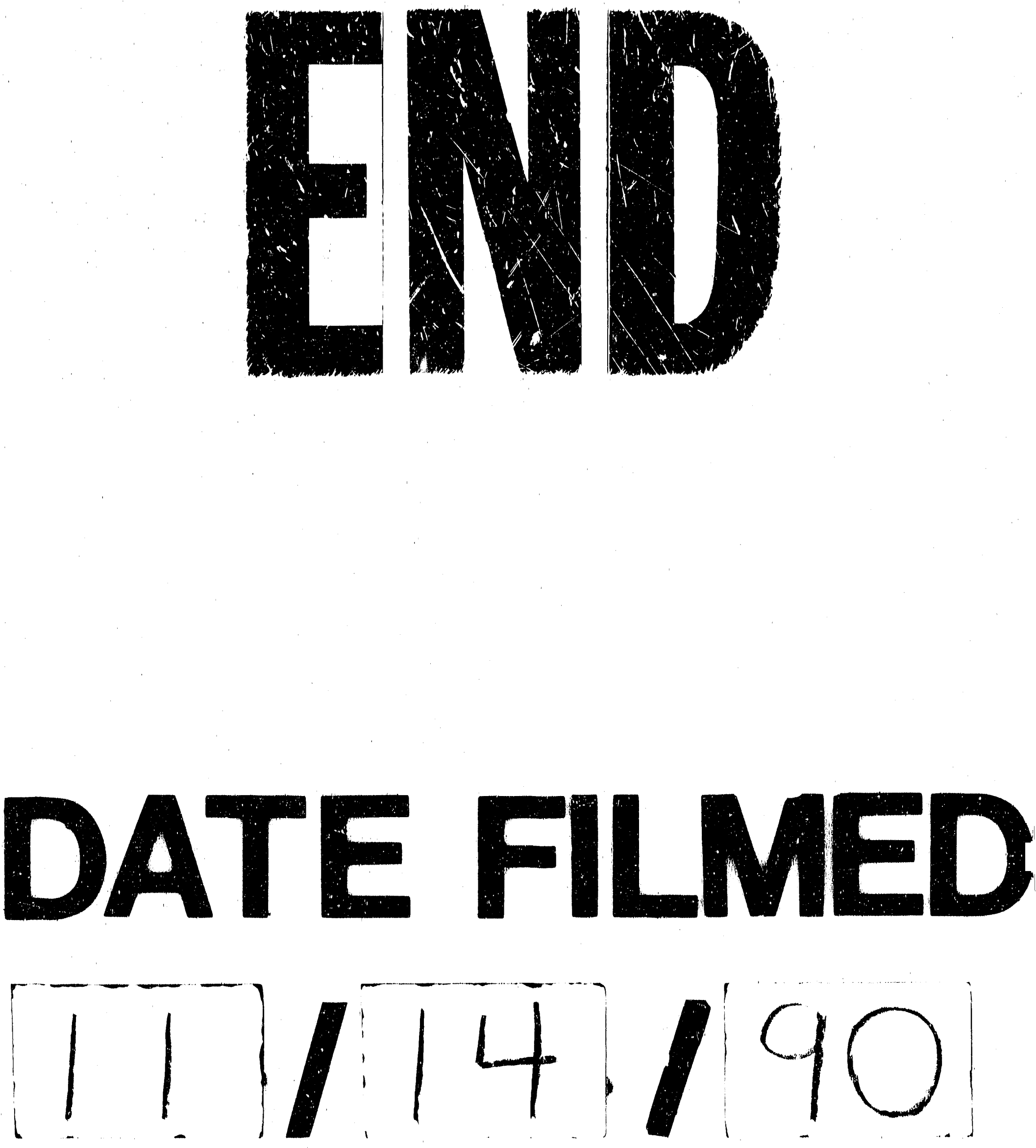
